Forecasting Climate-Induced Ecosystem Changes on Army Installations

James D. Westervelt and William W. Hargrove
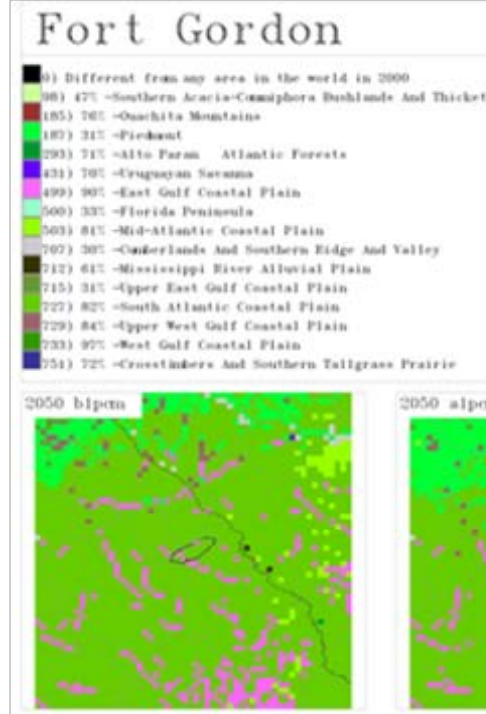

2100 bipon

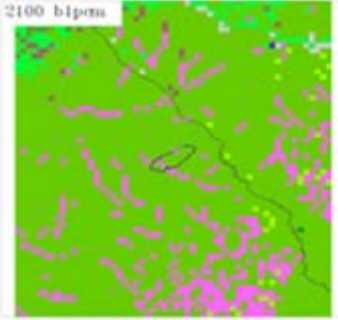

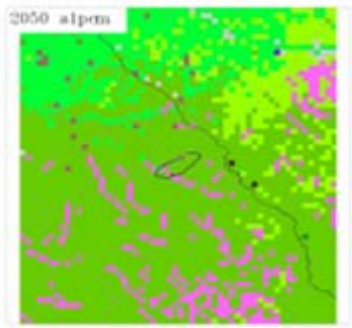

2100 alpow

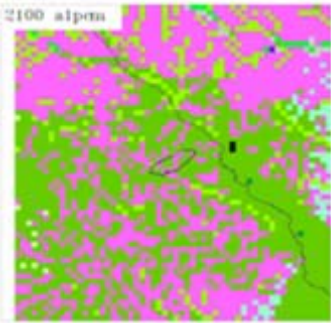

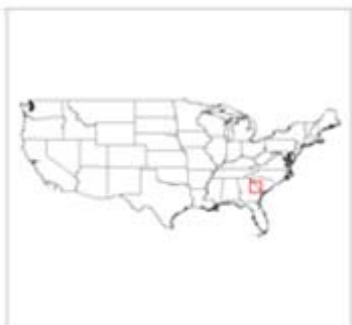
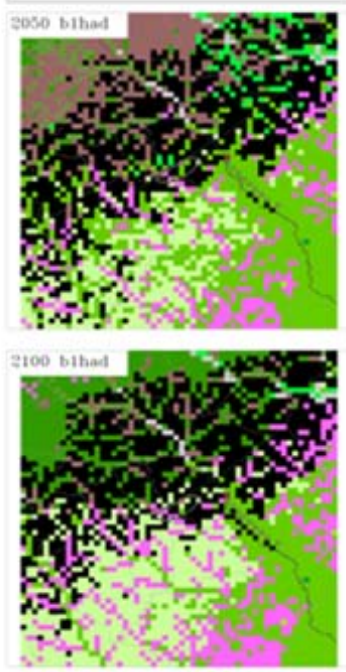
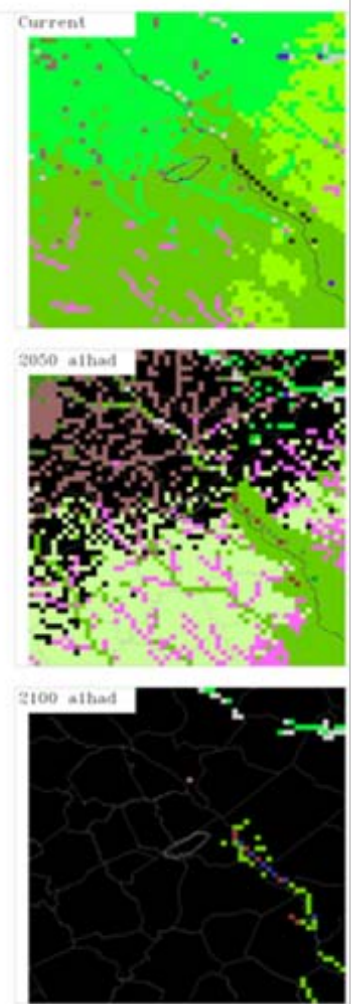



\section{Forecasting Climate-Induced Ecosystem Changes on Army Installations}

James D. Westervelt and William W. Hargrove

Construction Engineering Research Laboratory (CERL) US Army Engineer Research and Development Center 2902 Newmark Dr.

Champaign, IL 61822-1076

Final Report

Approved for public release; distribution is unlimited.

Prepared for Headquarters, US Army Corps of Engineers

Washington, DC 20314-1000 


\section{Abstract}

Military installation training lands must be managed to support species at risk as well as to be effective training environments for soldiers. Forecasts from various global climate change models suggest that the habitats associated with some military training installations will face pressures that induce biome-shifts, invasive species, loss of habitat, and changes in training opportunities. This study combined worldwide habitat forecast data with a current habitat map to identify major installations that appear to be most and least at-risk for habitat change.

DISCLAIMER: The contents of this report are not to be used for advertising, publication, or promotional purposes. Citation of trade names does not constitute an official endorsement or approval of the use of such commercial products. All product names and trademarks cited are the property of their respective owners. The findings of this report are not to be construed as an official Department of the Army position unless so designated by other authorized documents. 


\section{Table of Contents}

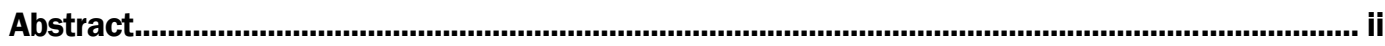

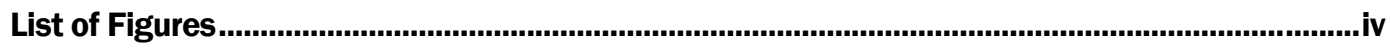

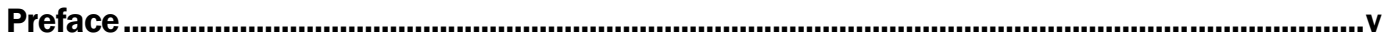

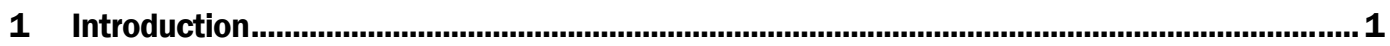

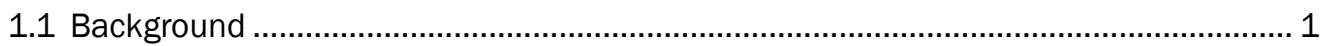

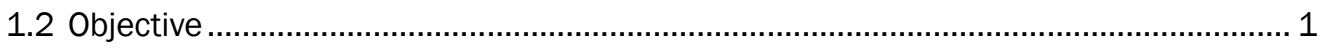

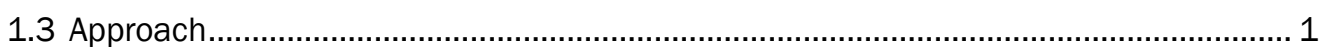

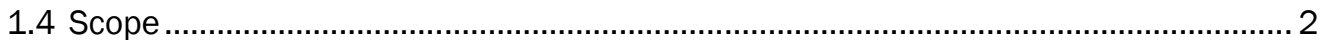

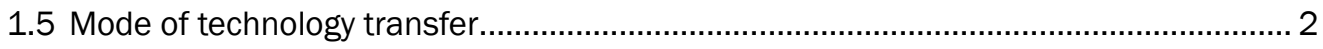

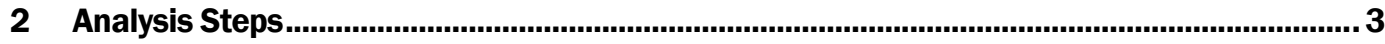

2.1 Steps 1 \& 2: Climate Modeling.................................................................................. 3

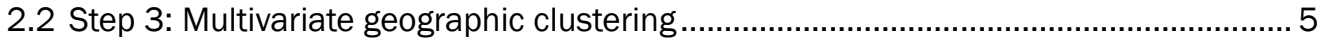

2.3 Step 4: Current habitat maps ................................................................................. 7

2.4 Step 5: Future habitat map ................................................................................ 10

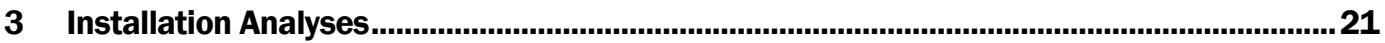

3.1 Step A1: Forecasting installation biome shifts ................................................... 21

3.2 Step A2: Find future areas in the present ............................................................ 22

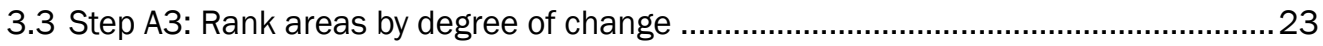

3.4 Step A4: Looking at raw change across CONUS .................................................. 24

4 Conclusions...............................................................................................................................29

4.1 "Which installations are most at-risk with respect to ecosystem changes?" ..............29

4.2 What is the range of anticipated ecosystem shifts based on the forecasts of general circulation models (GCMs)? ................................................................... 29

4.3 Where can one go today to find the ecosystem drivers (weather, climate, soil, and sun) anticipated in the future? ...................................................................... 30

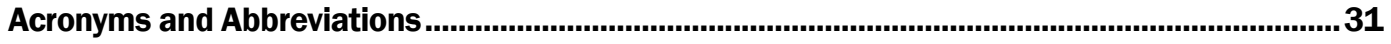

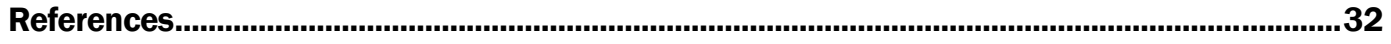

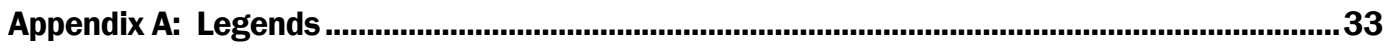

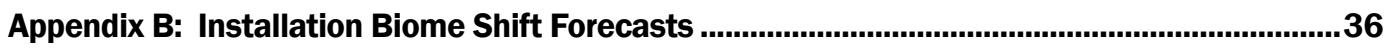

Appendix C: Ranking Army Installations....................................................................... 116

Report Documentation Page (SF 298) ......................................................................... 125 


\section{List of Figures}

\section{Figures}

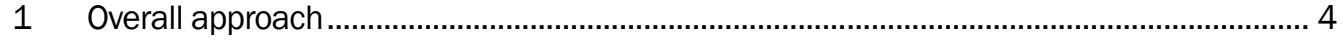

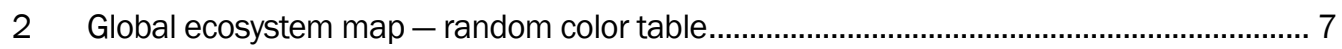

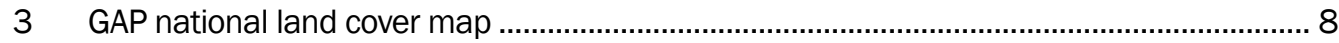

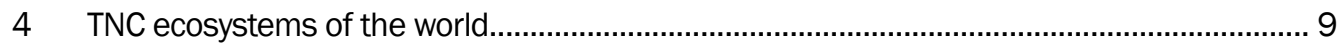

5 TNC ecosystems of the world - United States................................................................. 9

6 Global ecosystem map reclassified to GAP categories ......................................................... 11

$7 \quad$ Global ecosystem map reclassified to TNC categories ........................................................ 11

8 B1 Scenario, PCM Model; GAP Categories........................................................................ 13

9 A1 Scenario, PCM Model; GAP categories.......................................................................... 14

10 B1 Scenario, HAD Model; GAP categories......................................................................... 15

11 A1 Scenario, HAD Model; GAP categories ...................................................................... 16

12 B1 Scenario, PCM Model; TNC categories …….......................................................... 17

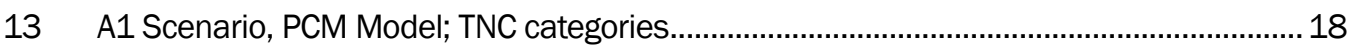

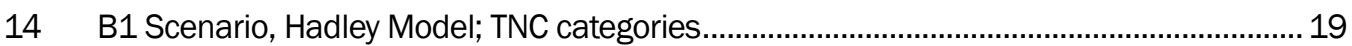

15 A1 Scenario, Hadley Model; TNC categories ................................................................. 20

16 Sample installation report showing local biome shift potentials ...................................... 22

17 Current location of forecast ecosystem conditions .............................................................. 23

18 Degree of change. Model: PCM, Scenario: A1 ................................................................ 25

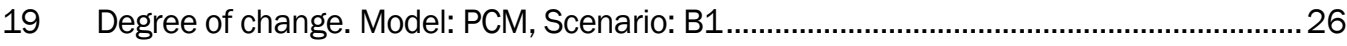

20 Degree of change. Model: Hadley, Scenario: A1 ……........................................................ 27

21 Degree of change. Model: Hadley, Scenario: B1 ….......................................................... 28

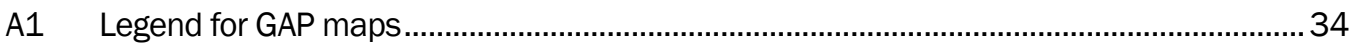

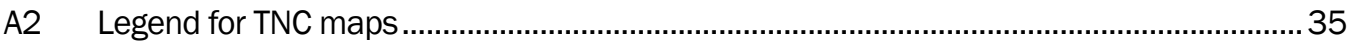




\section{Preface}

This study was conducted for Dr. Jeffrey Holland, Director of the Engineer Research and Development Center under a project called, "Integrated Risk Management for Climate Change," via the Center Directed Research Program. The project Principal Investigator was Dr. Todd Bridges of the Environmental Laboratory.

The work was performed by the Environmental Processes Branch (CN-N) of the Facilities Division (CF), Construction Engineering Research Laboratory (CERL). The CERL Principal Investigator was Dr. James Westervelt. William Meyer is Chief, CEERD-CN-N, and Dr. John Bandy is Chief, CEERD-CF. The Director of ERDC-CERL is Dr. Ilker R. Adiguzel.

CERL is an element of the US Army Engineer Research and Development Center (ERDC), US Army Corps of Engineers. The Commander and Executive Director of ERDC is COL Kevin J. Wilson, and the Director of ERDC is Dr. Jeffery P. Holland. 


\section{Introduction}

\subsection{Background}

Military installations and ranges support military training and testing across the United States. That land must be managed in a manner that ensures that the military continues to have excellent conditions to support the training and testing missions. An emerging potential threat to those conditions comes in the form of forecasted climate change, which might directly affect training by changing erosion challenges or by compromising training realism. Climate change may also indirectly affect training by changing the suitability of on-installation important habitats - including areas that support threatened or endangered species.

\subsection{Objective}

This objective of this work was to address three questions regarding the anticipated implications of forecast climate change in the Continental United States (CONUS):

- Which Army installations are most at-risk with respect to ecosystem changes?

- What is the range of anticipated ecosystem shifts based on the forecasts of general circulation models (GCMs)?

- Where can one go today to find the ecosystem drivers (weather, climate, soil, and sun) anticipated in the future?

\subsection{Approach}

This study assumed that ecosystems are driven by conditions involving temperature, rainfall, solar insolation, and soil characteristics. By correlating these conditions with the ecosystems found across the United States (and the globe), it is possible to forecast ecosystem shifts based on forecast changes to these conditions. Note that identifying shifts in conditions that might favor a different ecosystem is only the first step in actually forecasting the timing or speed with which any given area will shift. Ecosystems can be associated with a significant level of persistence and it can take decades or even millennia for seeds to establish themselves in distant areas. 


\subsection{Scope}

This study focused primarily on major CONUS Army installations.

\subsection{Mode of technology transfer}

This report will be made accessible through the World Wide Web (WWW) at URL: http://www.cecer.army.mil 


\section{Analysis Steps}

This study developed future habitat maps for the Continental United States based on forecasts from global climate change models and habitat classifications developed by the Gap Analysis Program (GAP). Developing future habitat maps involves five steps (Figure 1). Three subsequent analyses use these maps: (1) installation biome shift analysis, (2) an analysis to find current areas that represent forecast installation conditions, and (3) an analysis to rank installations by degree of ecosystem driver shifts. The following sections describe each of the steps taken to develop these future habitat maps.

\subsection{Steps 1 \& 2: Climate Modeling}

These efforts began with published data sets of current and future climate information created for the entire globe by the WorldClim group (http://www.worldclim.org). The climate modeling data development and analysis story begins with the running of General Circulations Models (GCM). The Intergovernmental Panel on Climate Change (IPCC), co-sponsored by the United Nations Environmental Programme (UNEP) and the World Meteorological Organization (WMO), is a focal point for coordinated global climate change analyses. In 2001, IPCC published the "Third Assessment Report" in four volumes. The first volume provides the scientific basis of the climate change analyses (IPCC 2001). From the IPCC 2001 analysis, results from two global climate models (GCMs, also known as general circulation models) were selected to represent forecast change extremes. The Hadley Centre model, HadCM3 (Wood et al. 1999), provides the conservative bookend. The National Center for Atmospheric Research (NCAR) Parallel Climate Model (PCM; Dai et al. 2001a; Hu et al. 2004) provides the more extreme forecasts.

These model the globe using grid cells that are roughly 3-degrees square. The Hadley model links an Ocean Model (HadOM3), which includes sea ice; with an atmospheric model (HadAM3). The PCM fully couples an 18level atmospheric general circulation model (GCM), the 32 level Los Alamos National Laboratory Parallel Ocean Program (POP; Smith et al. 1992; Dukowicz and Smith 1994) ocean GCM, a land surface model, and a dynamic-thermodynamic sea ice model (Washington et al. 2000). 


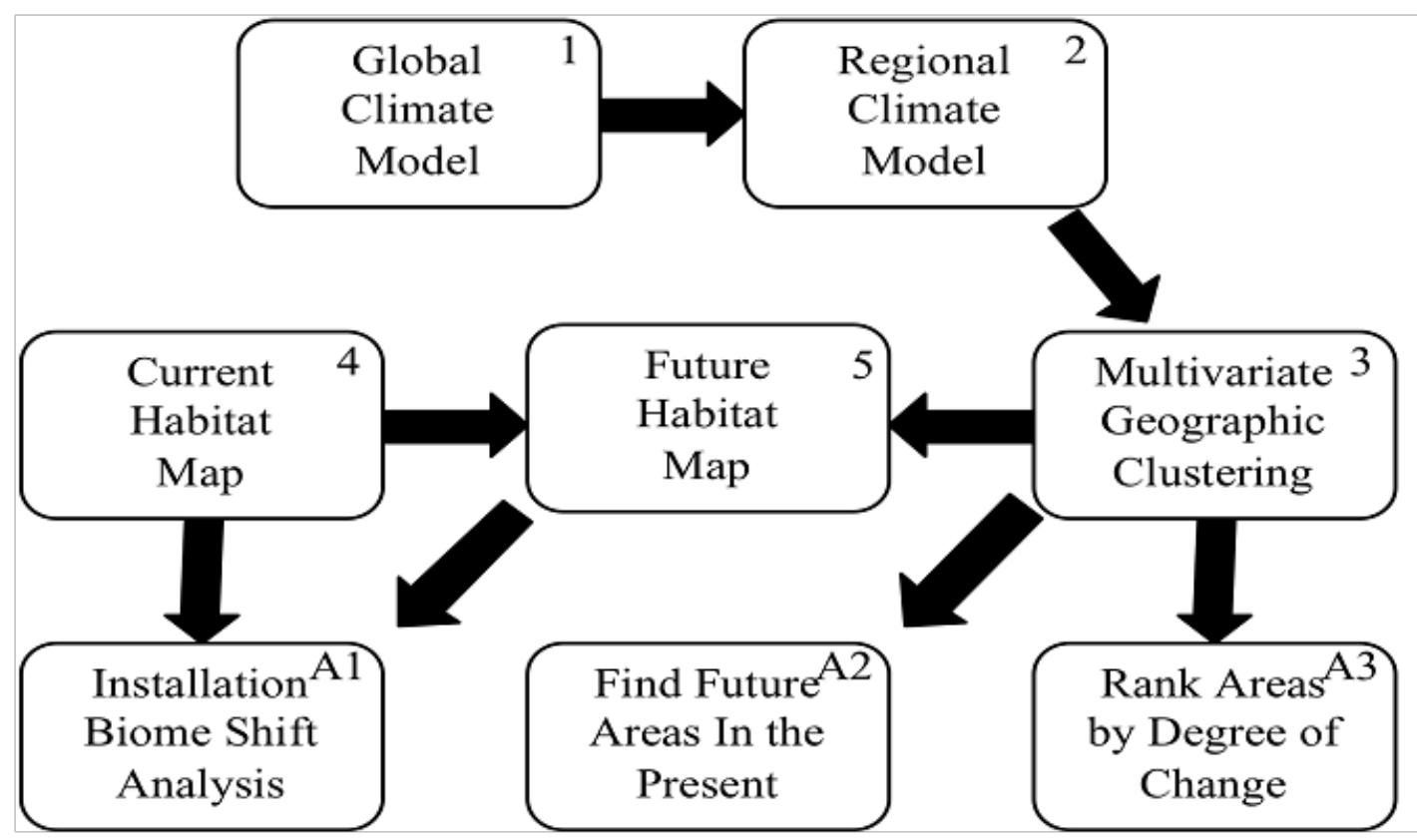

Figure 1. Overall approach.

These models were run using two internationally standardized gasemission scenarios: Scenario A1, ("business-as-usual"), which corresponds with the highest emissions; and Scenario B1, which corresponds with the lowest emissions. Climate states for 2050 and 2080 were captured for downscaling.

The GCM data were processed into global climate layers by the WorldClim group posted at the WorldClim website (http://www.worldclim.org). The WorldClim group specializes in the development of $\sim 1-\mathrm{km}$ resolution climate maps for the world using thin-plate spline interpolations of worldwide weather station data (Hijmans et al. 2005). To create future maps at this resolution, GCM outputs (typically at resolutions of about $110 \mathrm{~km}$ ) were compared with current conditions to create difference maps (of temperature and rainfall by season). These maps, in turn, were interpolated to the 1-km resolution and added to the equivalent WorldClim current weather maps (see: http://www.worldclim.org/downscaling). Using this approach, the WorldClim has processed 2020, 2050, and 2080 outputs from three GCM models that each ran A2A and B2B scenarios, for the third IPCC assessment report (TAR). For each model, scenario, and date combination, WorldClim generated monthly averages for maximum temperature, minimum temperature, and precipitation. 
Using the WorldClim results, Chris Zganjar, of The Nature Conservancy, developed and ran geographic information processing scripts to generate nine maps that represent current conditions and future conditions (2050 and 2080) for two scenarios run by two GCMs. The resulting maps represent the current global system and the combinations of the two models, two scenarios, and 2 future years:

1. Precipitation during the locally hottest quarter

1. Precipitation during the locally coldest quarter

2. Precipitation during the locally driest quarter

3. Precipitation during the locally wettest quarter

4. Ratio of precipitation to potential evapotranspiration

5. Temperature during the coldest local quarter

6. Temperature during the hottest local quarter

7. Sum of local monthly Tavg where Tavg $>=5{ }^{\circ} \mathrm{C}$

8. Integer number of consecutive months where Tavg $>=5{ }^{\circ} \mathrm{C}$ (Length of potential growing season).

\subsection{Step 3: Multivariate geographic clustering}

Hargrove and Hoffman (2005) reviewed the history of statistical and geographic information system (GIS) based ecosystem map development and then described their Multivariate Geographic Clustering (MGC) empirical process for identifying habitats. They used nine characteristics captured as maps for the conterminous United States:

1. Plant-available water capacity

9. Soil organic matter

10. Total Kjeldahl soil nitrogen

11. Depth to a seasonally high water table

12. Mean precipitation during the growing season

13. Mean insolation during the growing season

14. Degree-day heat sum during the growing season

15. Degree-day cold sum during the non-growing season

16. Elevation.

Maps were at a resolution of $1-\mathrm{km}$. Each of the maps was converted to non-dimensional forms by assigning standard-deviation values from the means of each of the maps values. This resulted in each location being characterized by a coordinate point in the 9 dimensions. Hargrove and Hoffman used a two-step process using clustering and classification to 
classify all locations. In the first step, the 9-dimensional space was divided in up to 3000 cluster centers that were then moved around the space until each cluster signature was associated with a similar number of locations (a subset of $1-\mathrm{km}$ cells). With the established cluster means, each location was then assigned to the cluster that has the closest Euclidian distance in the 9-dimensions.

This study applied the MGC procedure simultaneously using nine sets of 16 map layers representing the current global state and the eight forecast future states:

1. Precipitation during the locally hottest quarter

17. Precipitation during the locally coldest quarter

18. Precipitation during the locally driest quarter

19. Precipitation during the locally wettest quarter

20. Ratio of precipitation to potential evapotranspiration

21. Temperature during the coldest locally quarter

22. Temperature during the hottest locally quarter

23. Sum of monthly Tavg where Tavg $>=5{ }^{\circ} \mathrm{C}$

24. Integer number of consecutive months where Tavg $>=5{ }^{\circ} \mathrm{C}$ (Length of potential growing season)

25. Available water holding capacity of soil

26. Bulk density of soil

27. Carbon content of soil

28. Nitrogen content of soil

29. Compound topographic index (relative wetness)

30. Solar interception

31. Day/night diurnal temperature difference.

To facilitate the combination and comparison of these maps through a cluster analysis, each was transformed by calculating the standard deviation of the maps' values. This resulted in a 16-value signature for every one of 48.6 million 2-minute square cells for the globe (including water areas) between 60 degrees south latitude and 90 degrees north latitude $(10,800$ columns and 4500 rows). The signatures for all land areas and for all maps were then clustered into 30,000 clusters. This large number of clusters allows for relatively fine separation of habitat types, yielding an average of about 500 cells per cluster. Figure 2 shows the resulting map for the area of the United States based on current (2000) conditions. 


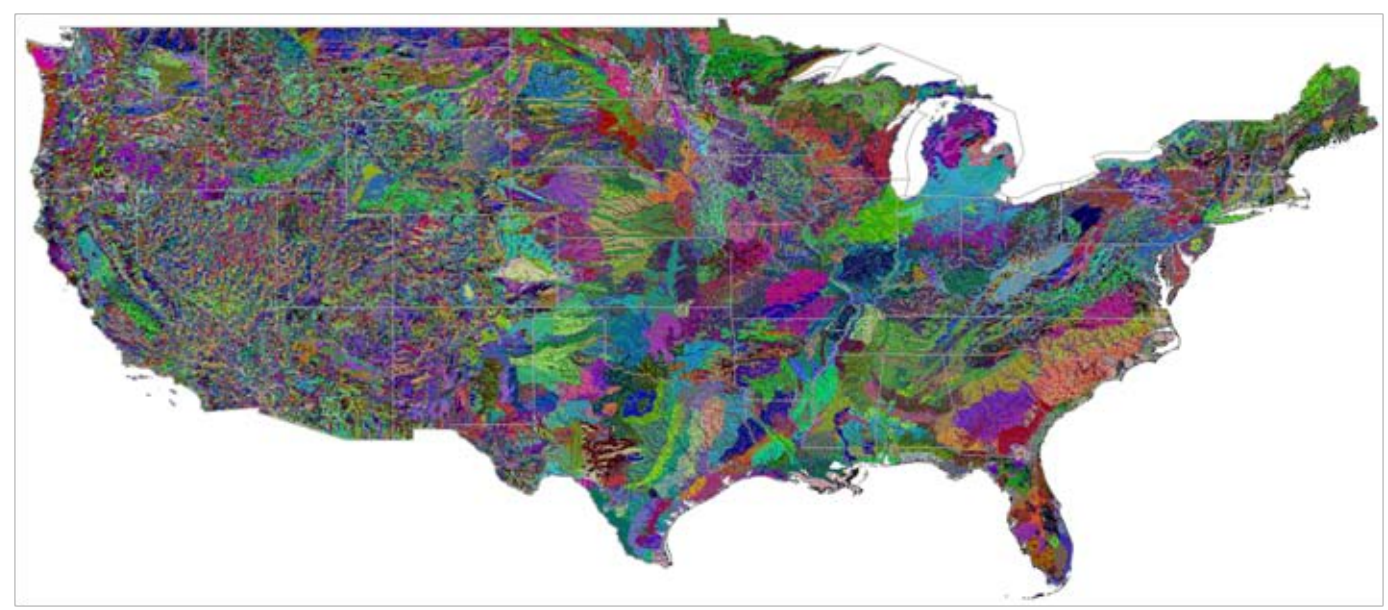

Figure 2. Global ecosystem map - random color table.

The color table is random and shows areas that are similar in the combination of the conditions represented in the 16 input maps. Note that analysis was done for the entire globe and for the eight future condition combinations. This means that areas with the same set of conditions anywhere in the world and/or any time in the future are assigned the same cluster number. The averages of the conditions for all locations associated with a cluster results in a signature for that cluster. This results in an extremely powerful set of maps that can be used for answering a wide variety of questions. Any naturally occurring thing on the earth can be located in the current map to identify the associated clusters and signatures, which can be located across the earth, currently and in the future.

For example, by identifying the location of oak-hickory assemblages, one can then identify the gridcells associated with those areas and find out what clusters they represent. By highlighting the gridcells across the country (or globe) across the future conditions, it is possible to identify where the conditions are forecast to be found that are currently associated with oak-hickory forests. This procedure can be used for locating the future locations of areas that share the ecosystem drivers currently associated with habitat, species, growing areas, cities, forests, or military installations.

\subsection{Step 4: Current habitat maps}

The 30,000 cluster categories generated for the globe across the current and nine future scenarios are simply statistically-similar areas based on standard-deviation values representing 16 distinct soil characteristics, solar interception, and climate values. Correlating these clusters with ac- 
cepted habitat types is relevant to this work. This begins with selecting a habitat classification. Many habitat classification maps have been developed for the United States. Early examples include the Bailey (1983, 1995, 1996) and Omernick (1987) classification maps. Bailey generated maps at three levels of detail, identifying 52 ecoregions at the finest level. For studying water resources, Omernick identified 76 national ecoregions. These maps were created through a combination of computer-assisted classification of mapped data and subjective expert opinion.

This study selected two modern ecosystem classifications. The first, the GAP national land cover map, was developed by the GAP program (Davidson, 2010) and uses the Ecological System classification system developed by NatureServe to represent natural and semi-natural land cover, and covers the continental United States.

Ecological systems were developed as a means of representing recurring groups of biological communities that are found in similar physical environments and that are influenced by similar dynamic ecological processes, such as fire or flooding. In addition, the national map contains 551 Ecological Systems and modified Ecological Systems containing 39 land use classes, which are depicted developed and disturbed land cover classes (GAP 2011).

Figure 3 shows the GAP map for the United States. Note that Appendix A to this report (Figure A1,p 34) contains the legend for this map (and all maps derived from this GAP map).

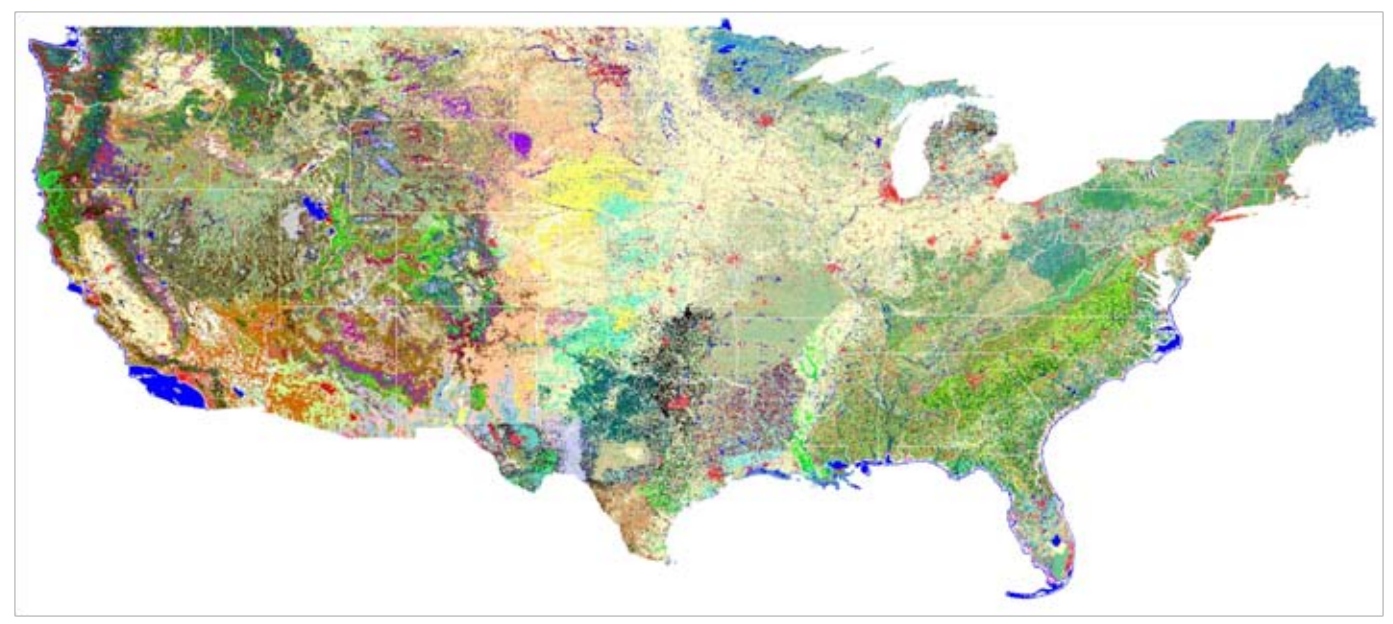

Figure 3. GAP national land cover map. 
The second ecosystem map adopted covers the globe and was developed by the Nature Conservancy (TNC) as a unified global representation of ecosystems. Figure 4 shows the global TNC map* and Figure 5 shows the corresponding CONUS map. Figure A2 ( $p$ 35) contains the legend for the TNC maps. Note that the GAP ecosystem map is much more detailed than the TNC map (688 categories across the globe, but only 70 across CONUS).

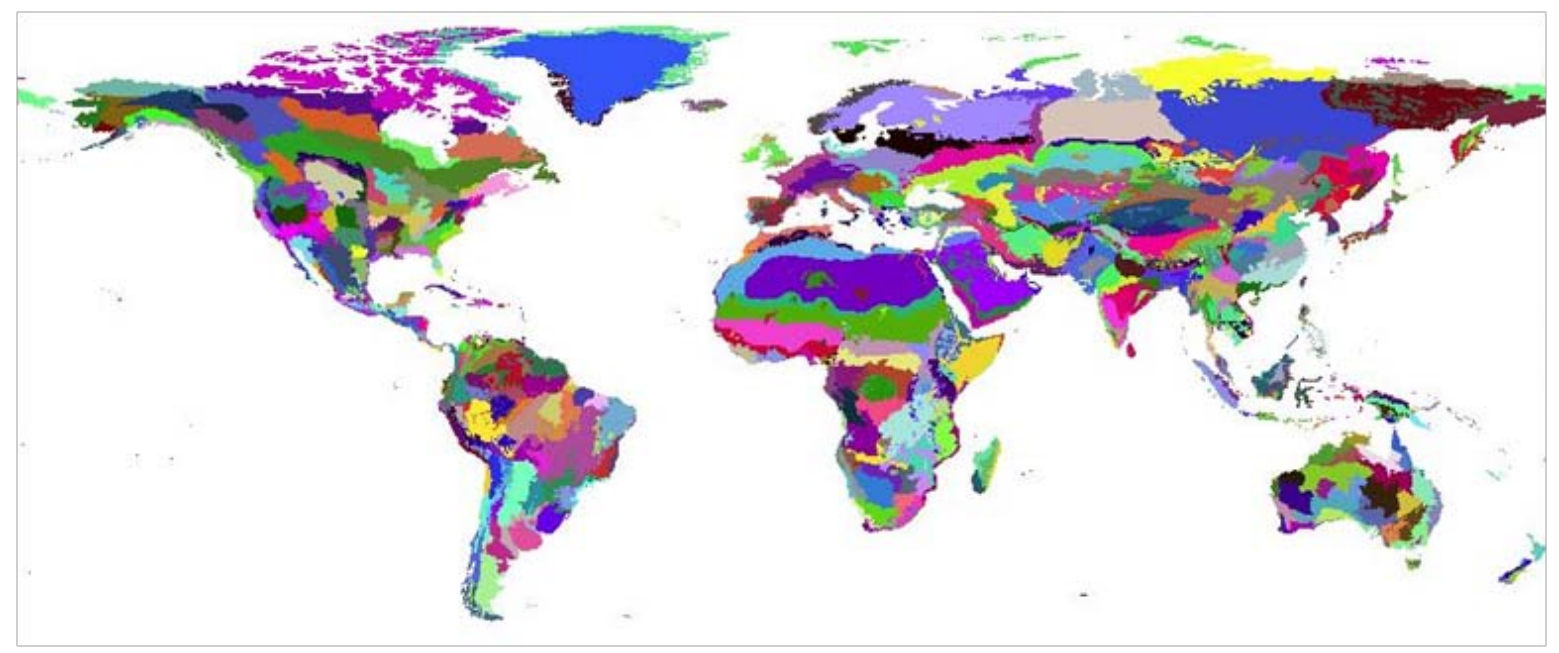

Figure 4. TNC ecosystems of the world.

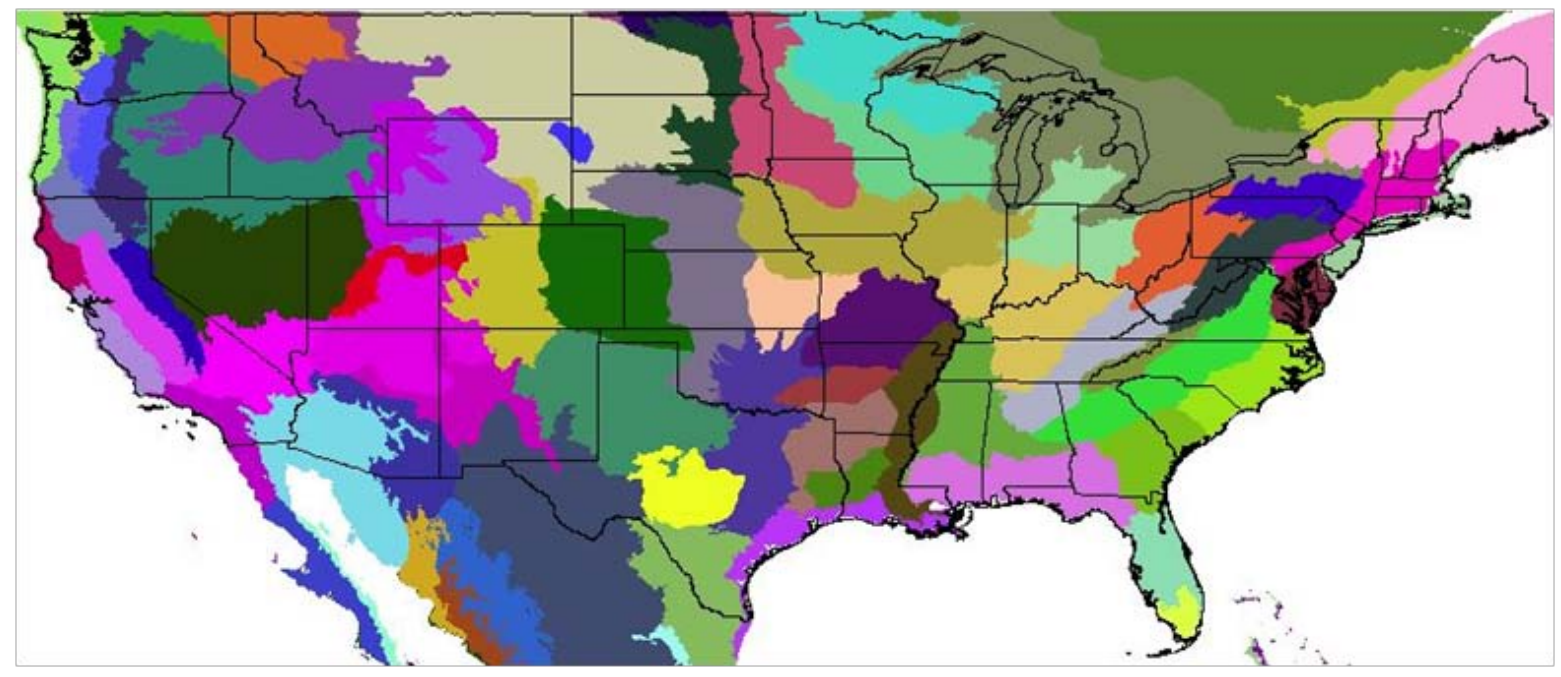

Figure 5. TNC ecosystems of the world - United States.

* Also available through URL: http://www.nature.org/multimedia/maps/ 


\subsection{Step 5: Future habitat map}

The goal of this step was to generate a consistent set of one current and eight future habitat maps based on the 551 GAP ecosystem and land use classes for CONUS and the 688 TNC ecosystem classes for the world. These are based on all combinations of two GCM models (Hadley and PCM), two scenarios (A1 and B1 emission levels), and two future times: 2050 and 2080. This step begins with eight future maps (and a current map) that have been collectively classified into 30,000 habitat clusters (Step 3). That is, each of the nine maps shares the same cluster values. Therefore, if the cluster categories in any one of the maps can be associated with ecosystems, then that same association can be shared with the other eight maps. This was done by cross-referencing the 551 GAP ecosystem and land use classes (Figure 3) with the cluster categories (Figure 2) (4284 categories of the 30,000 across the world, across the nine maps) found in the conterminous current map. Counts were made of the number of cells sharing each GAP category with the various cluster categories. For each cluster category, a count of the number of cells containing each shared GAP category was established and the most commonly shared GAP category was then assigned to each respective cluster category.

The reassignment relating Figure 2 to Figure 3 resulted in the map shown in Figure 6. The 4284 cluster categories mapped into 243 (less than half) of the 551 GAP categories. Many GAP categories that represented small areas were washed out in the process - leaving only the more dominant ecosystem types. The cross-referencing established for the current map was then applied to all of the future maps - providing the basis for forecasting ecosystem change.

The same procedure was followed with the global TNC map. Each of the clusters was associated with the one TNC ecosystem type that most frequently correlated with the cluster. Unlike the GAP-based analysis, this was done with the global map. Figure 7 shows the result for CONUS.

There are two interesting differences between Figure 7 and Figure 5. First, the number of ecosystem categories across the United States increased from 70 to 287 . This is because the entire globe was analyzed simultaneously and there are many cases where small areas in CONUS share the ecosystem driver conditions associated with broader areas elsewhere. 


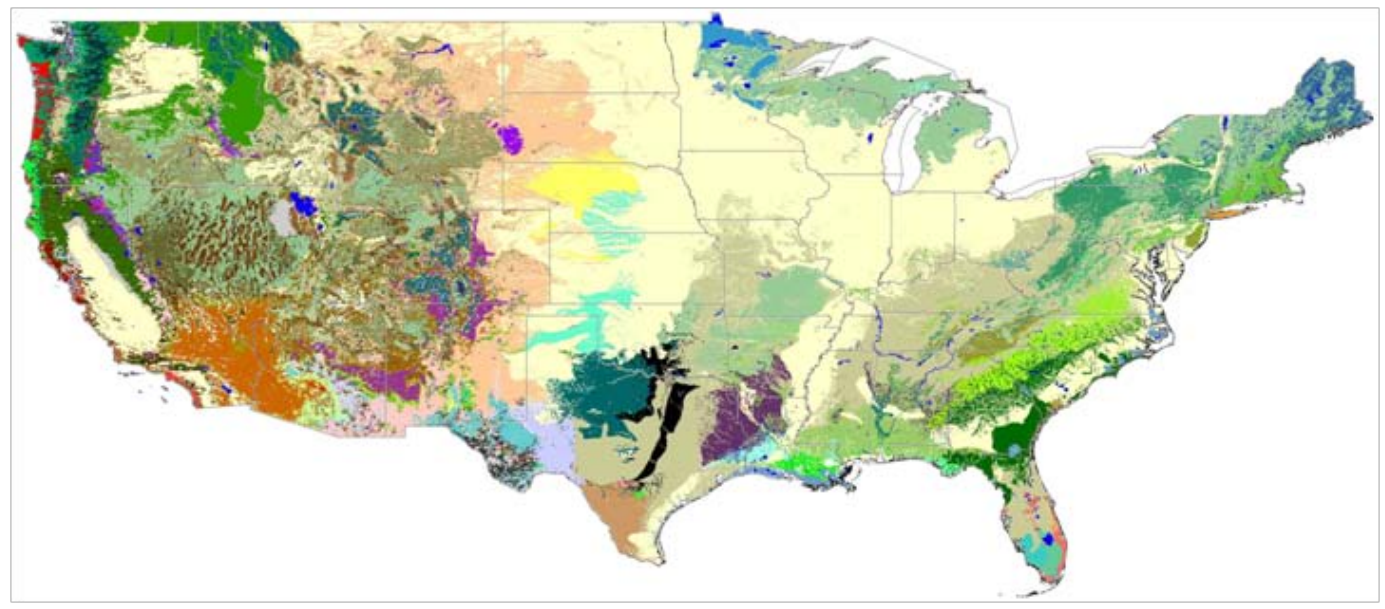

Figure 6. Global ecosystem map reclassified to GAP categories.

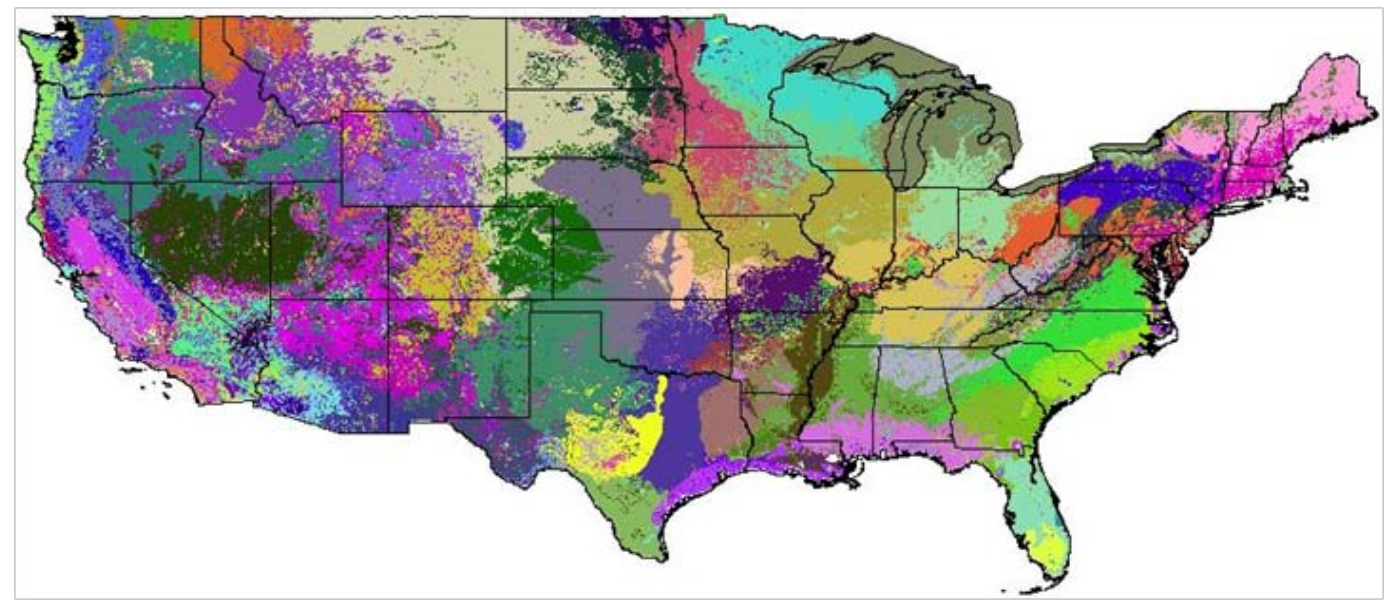

Figure 7. Global ecosystem map reclassified to TNC categories.

In many cases, these areas in CONUS can be very small. Second, while the ecosystem areas are grossly located similarly across the states, the edges of the ecosystem areas are much more jagged in the new map (Figure 7), more accurately representing reality in nature, and its lack of solid edges.

The new GAP and TNC maps were generated using lookup tables that associate each cluster to the associated ecosystem type. By applying these two lookup tables to the eight future maps, it is possible to generate sets of GAP and TNC-based ecosystem maps.

Future time series for each of the two models and the two emission time series are displayed for the GAP-based series in Figures 8 to 11; and for the TNC-based series in Figures 12 to 15. These are in order of apparent eco- 
system impact severity. The PCM B1 scenario results are captured in Figures 8 and 12. The top image in each shows the current system state, the center image shows the scenario projected for 2050, and the bottom image, the scenario projected for 2080. This pattern is repeated in Figures 13 to 15. Significant shifts are evident in even the least dramatic forecast of change. Note, for example, the northern shifts in northern Texas and into Oklahoma. Northward shifts are also easily apparent in the Appalachian ecosystems.

The A1 scenario PCM model results (Figures 9 and 11) show similar, but more dramatic, changes. Note the changes throughout most of the country. Note the white areas throughout the 2080 map. Most of these areas represent changes that have no current United States ecosystem analogs. In some cases, these can be mapped to existing areas elsewhere in the world. In other cases there are no current world analogs.

The B1 and A1 Hadley results follow in Figures 10 and 11 (and Figures 14 and 15) respectively. The B1 forecast is more severe than the PCM A1 results. The A1 results suggest extremely dramatic changes throughout most of the country. 


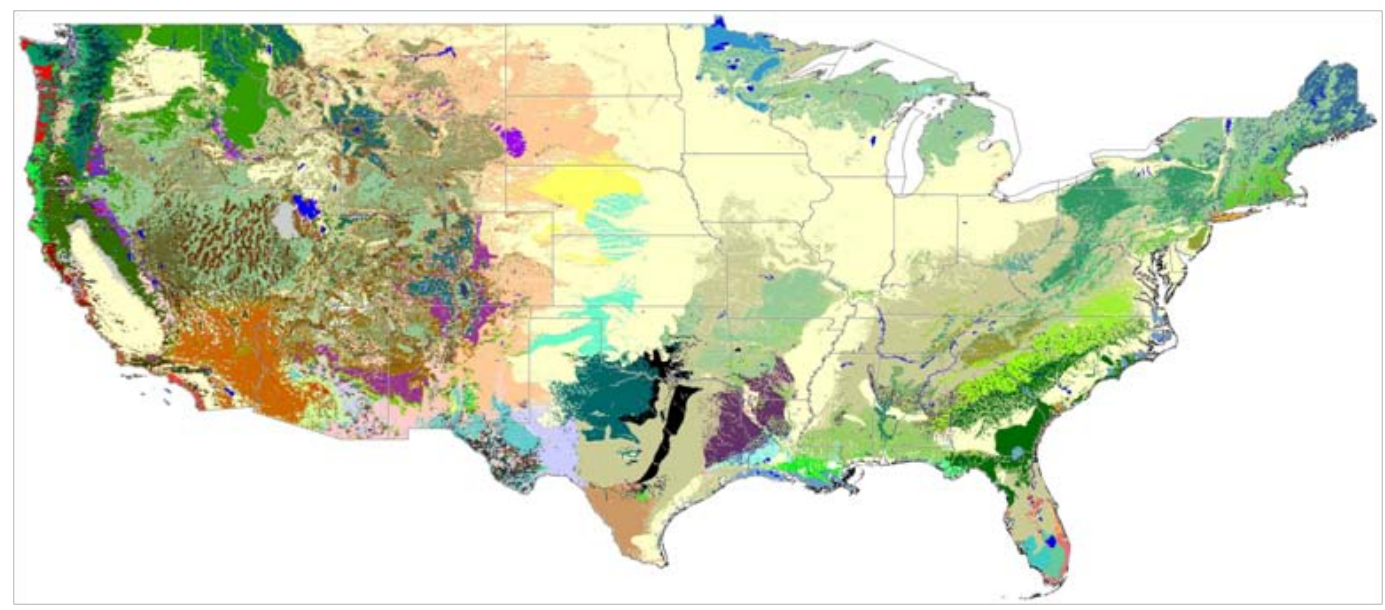

Current
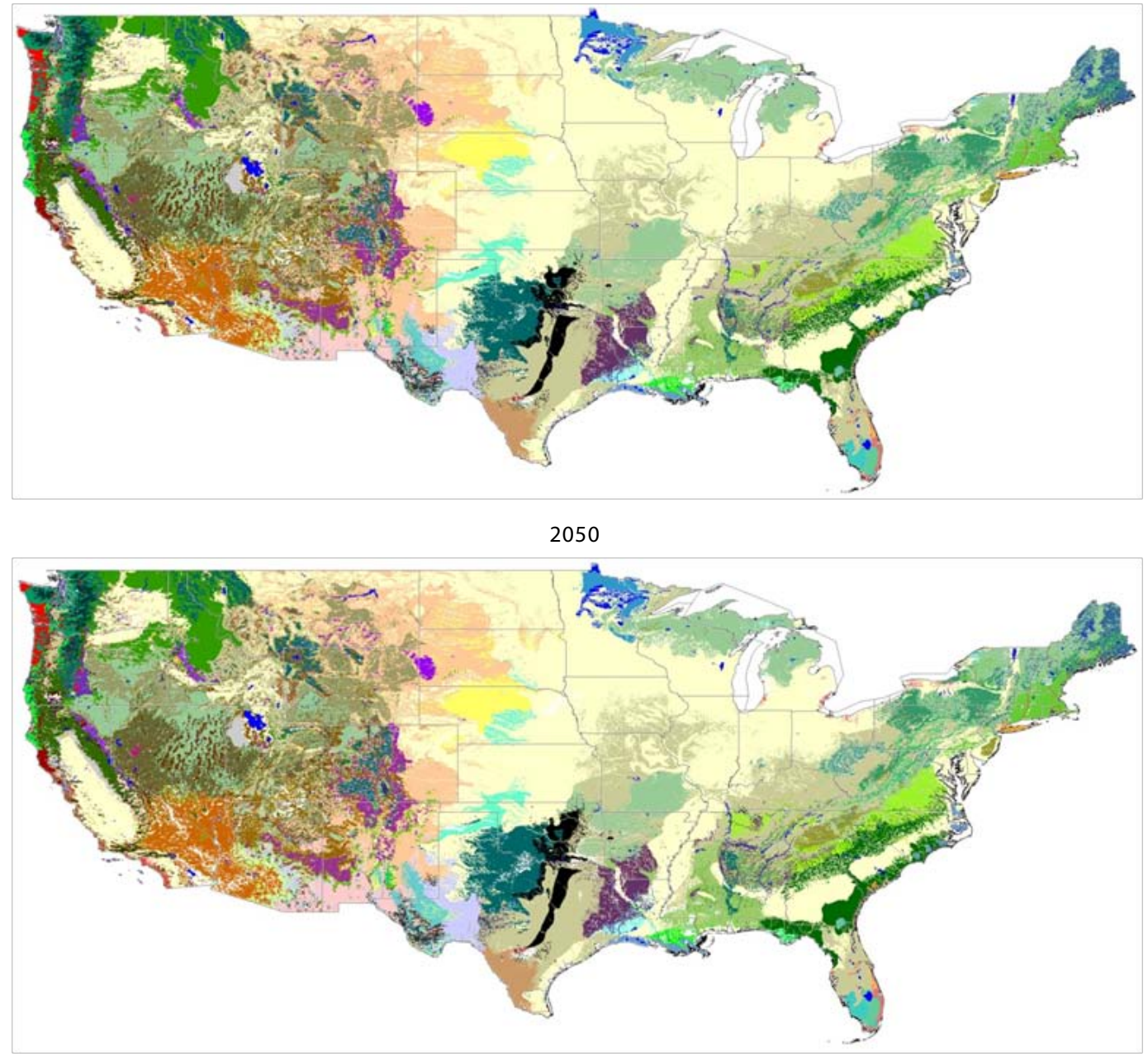

2080

Figure 8. B1 Scenario, PCM Model; GAP Categories. 


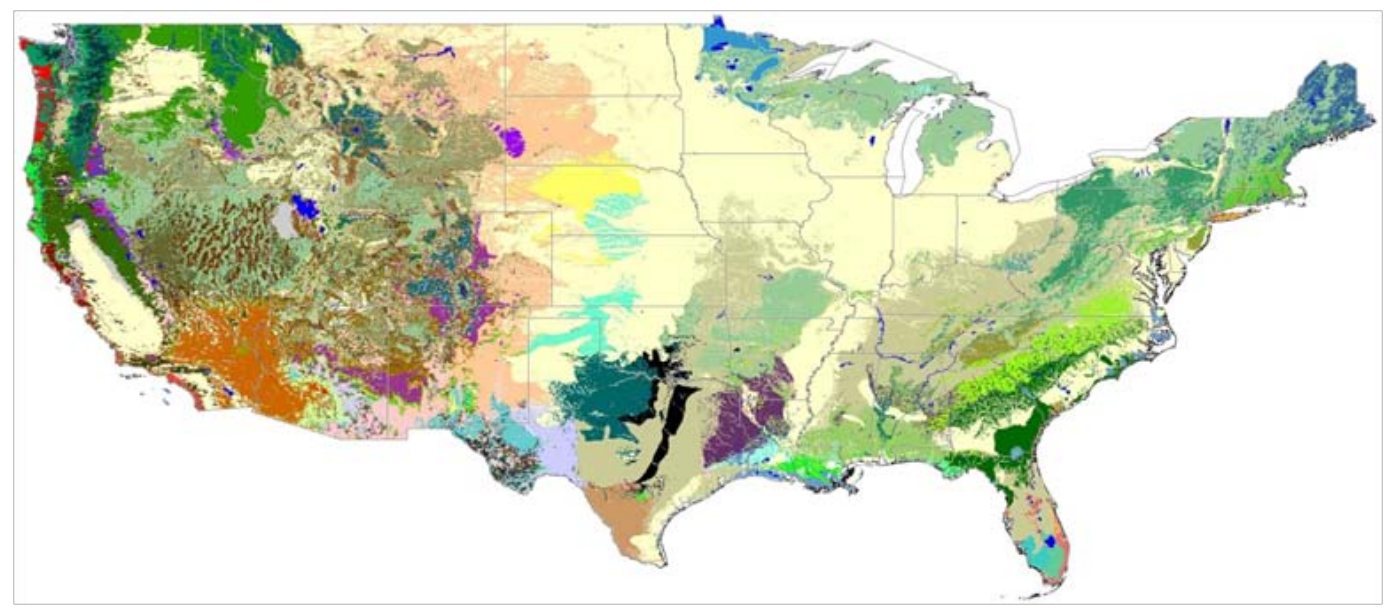

Current

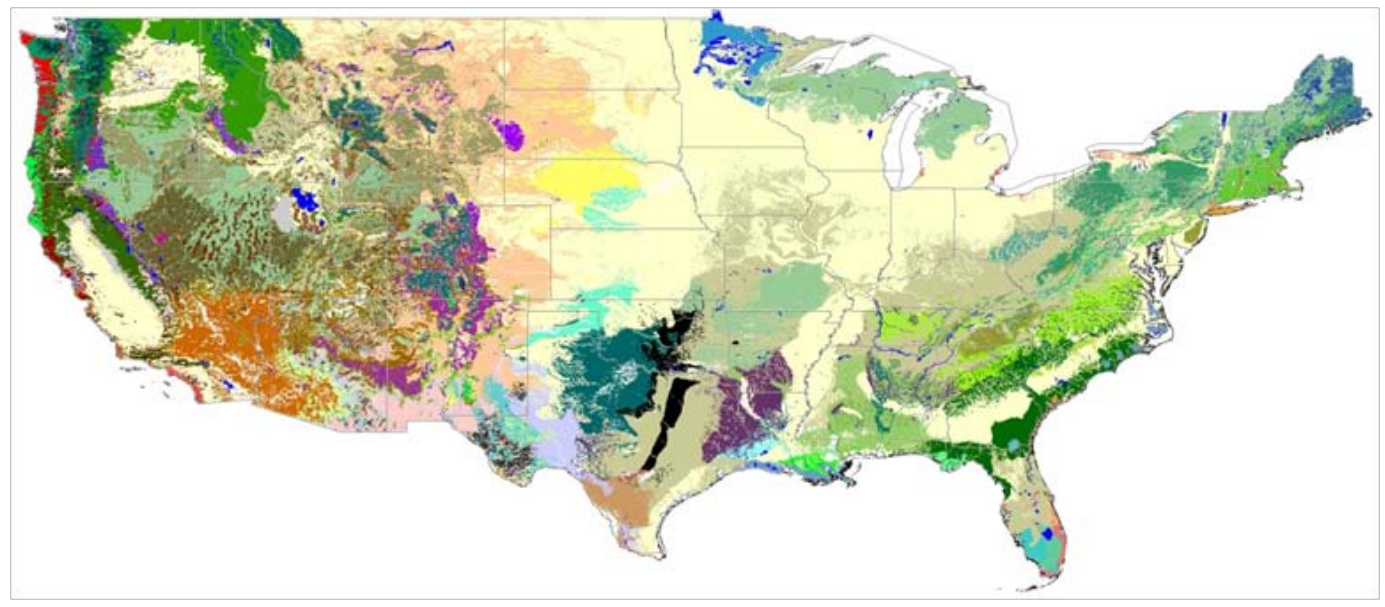

2050

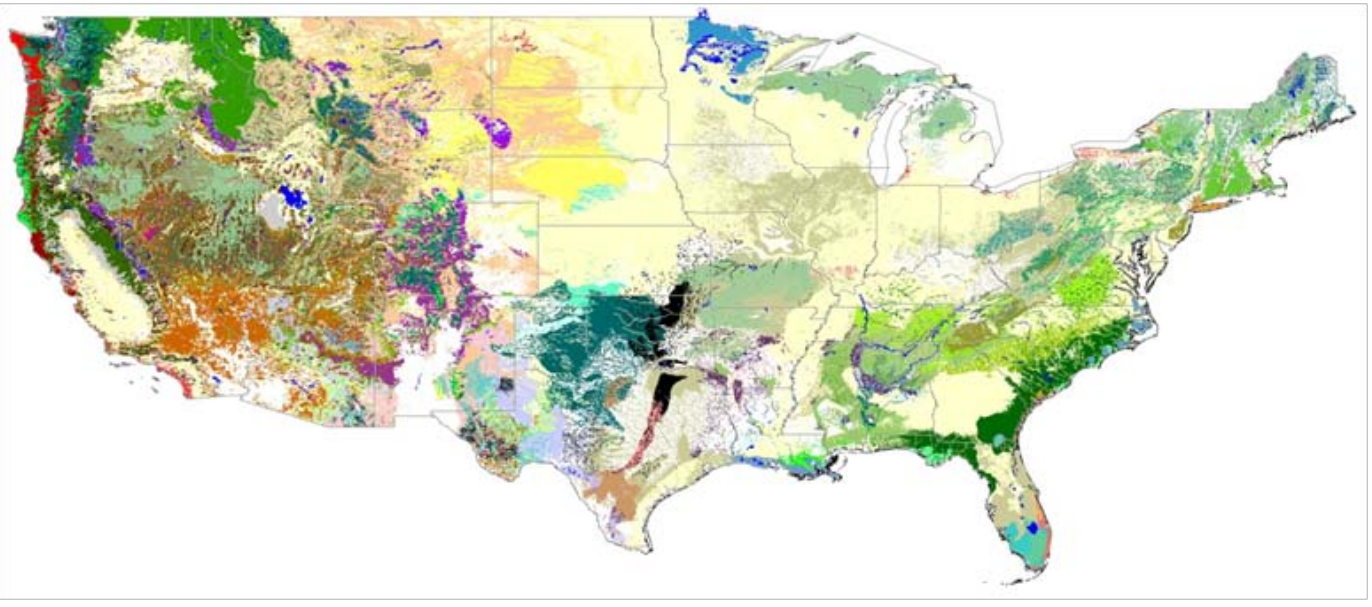

2080

Figure 9. A1 Scenario, PCM Model; GAP categories. 


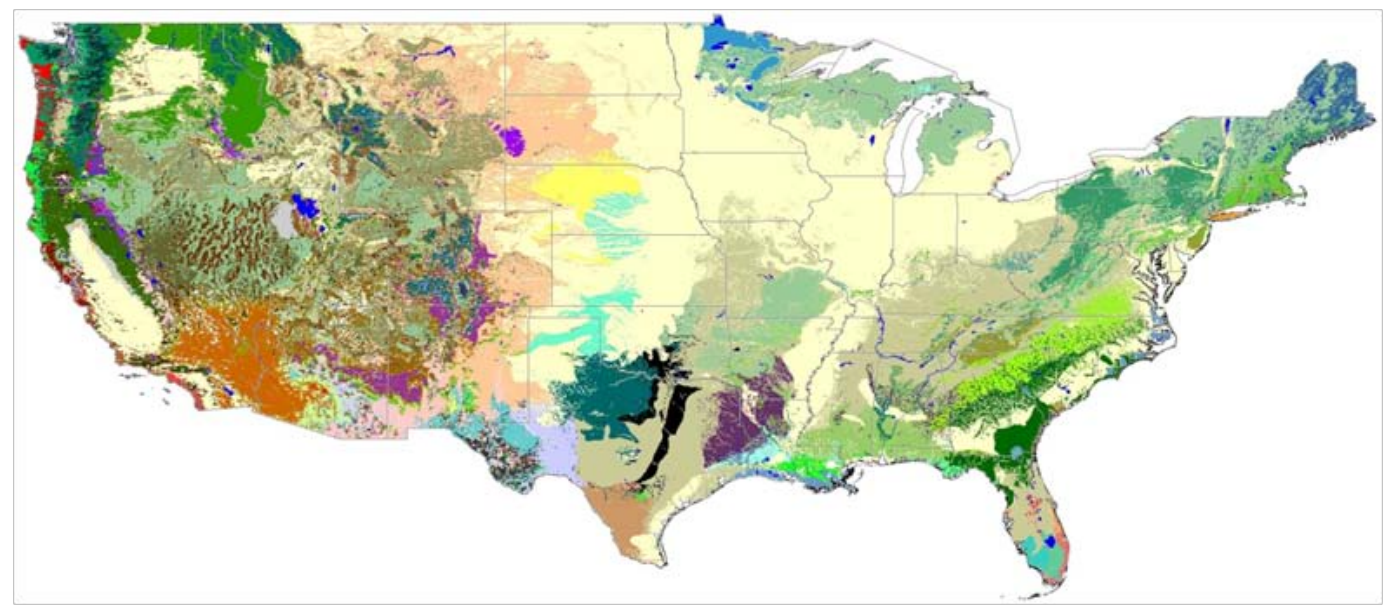

Current
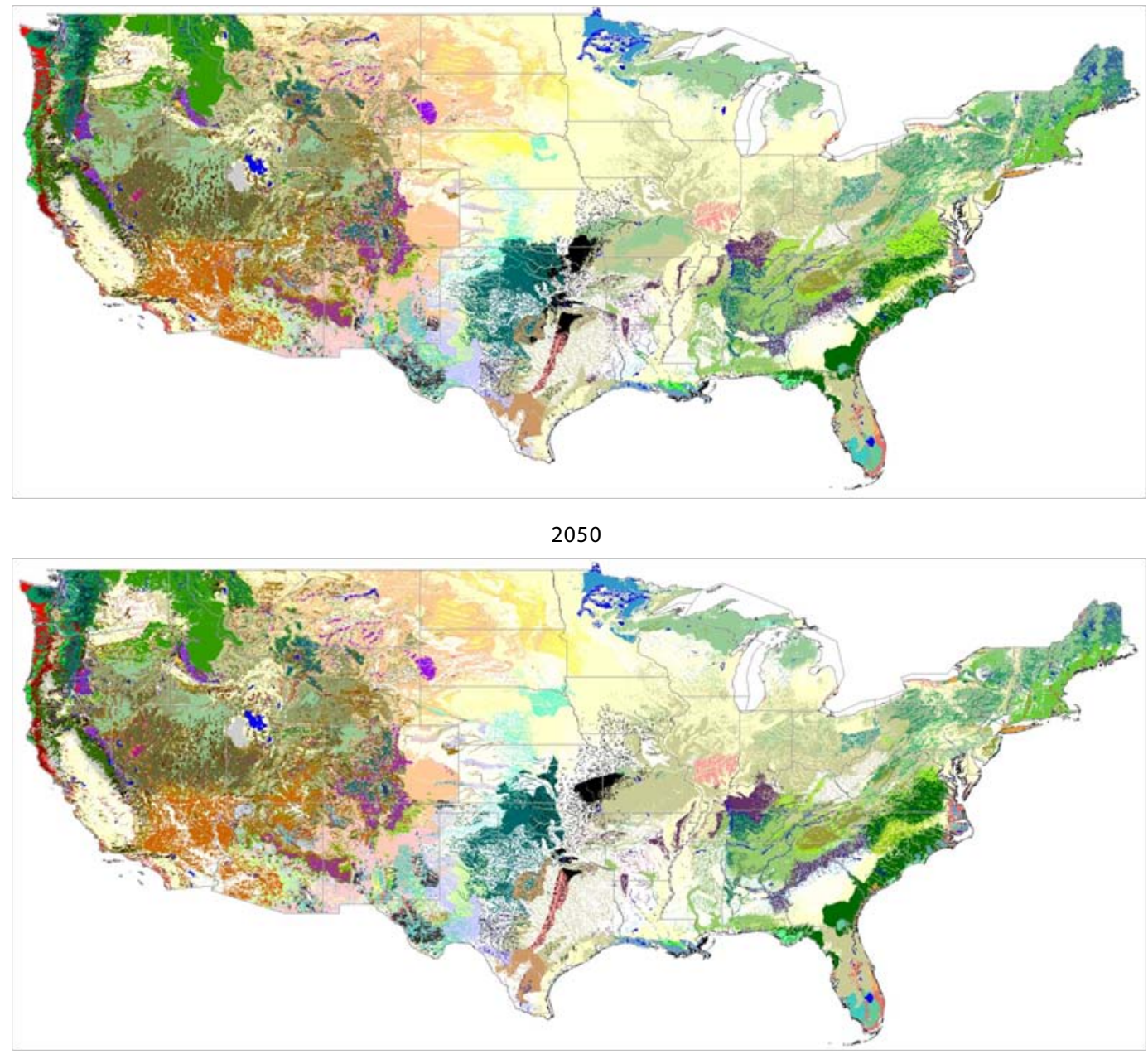

2080

Figure 10. B1 Scenario, HAD Model; GAP categories. 


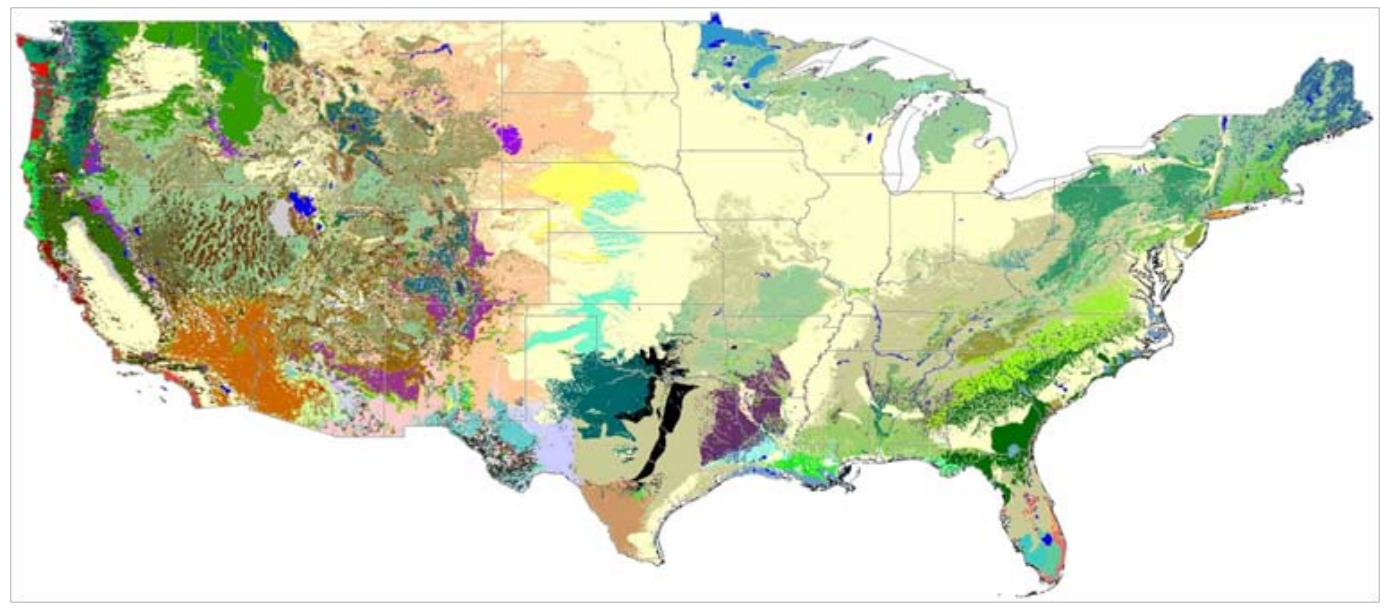

Current
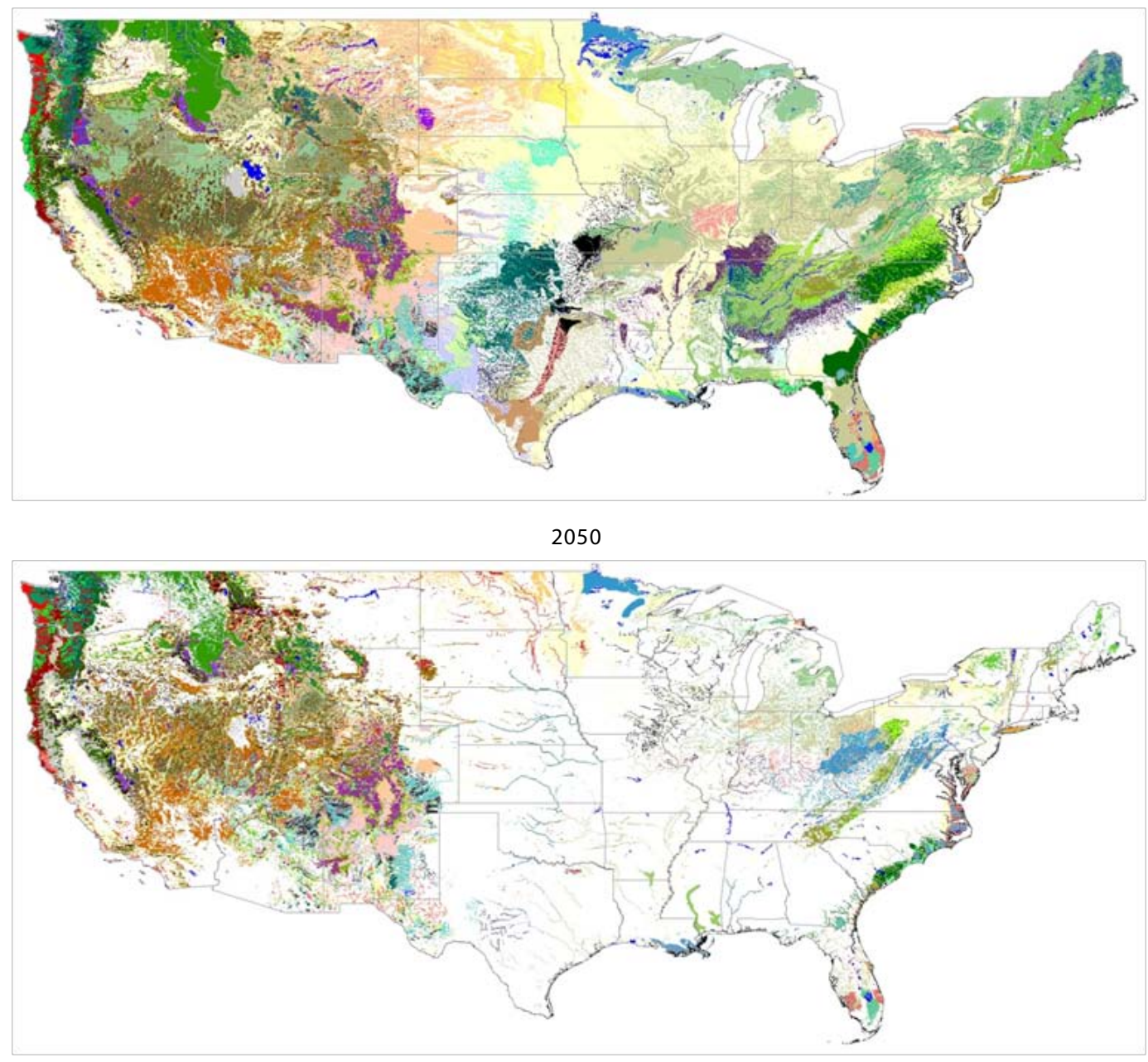

2080

Figure 11. A1 Scenario, HAD Model; GAP categories. 

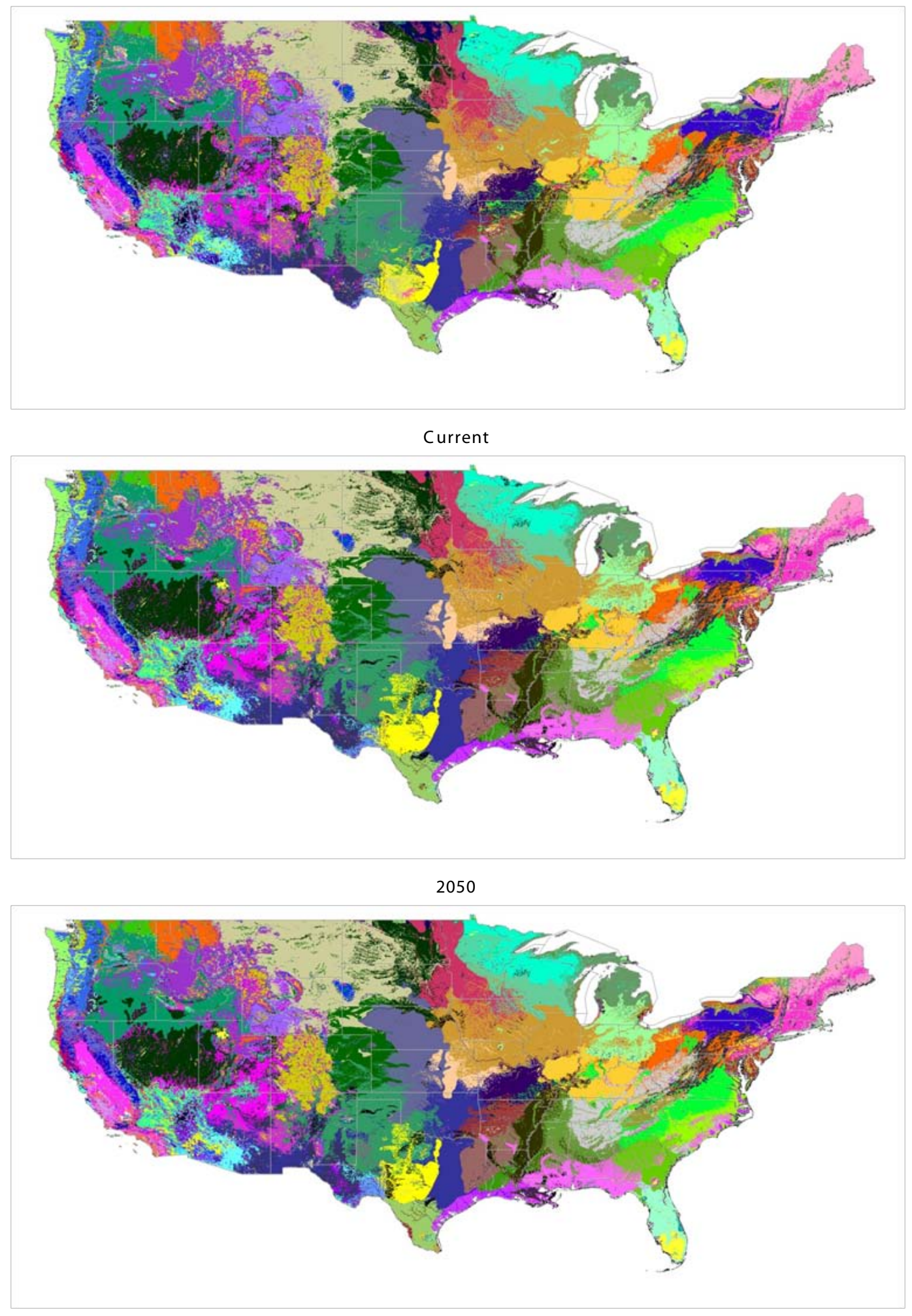

2080

Figure 12. B1 Scenario, PCM Model; TNC categories. 

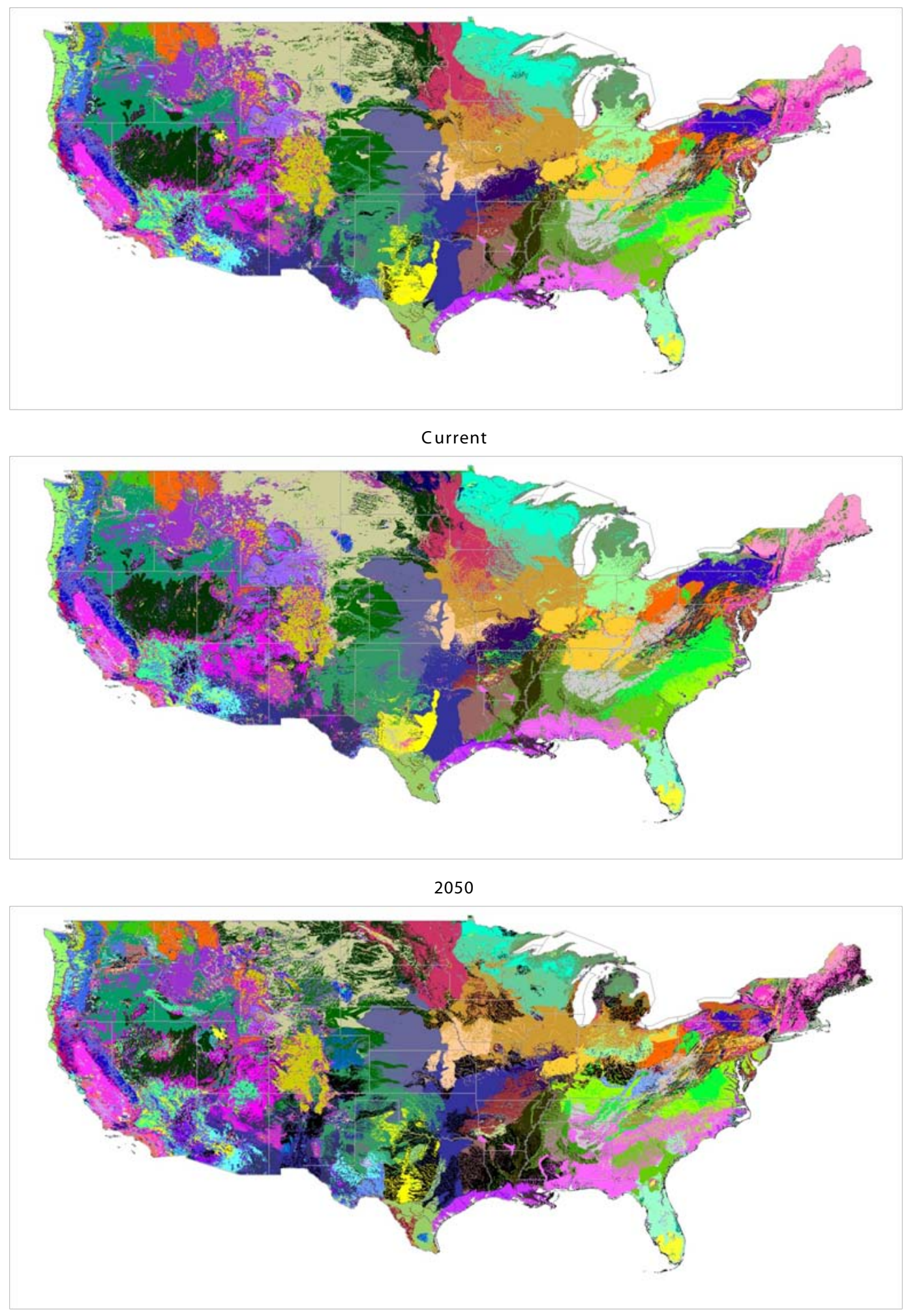

2080

Figure 13. A1 Scenario, PCM Model; TNC categories. 

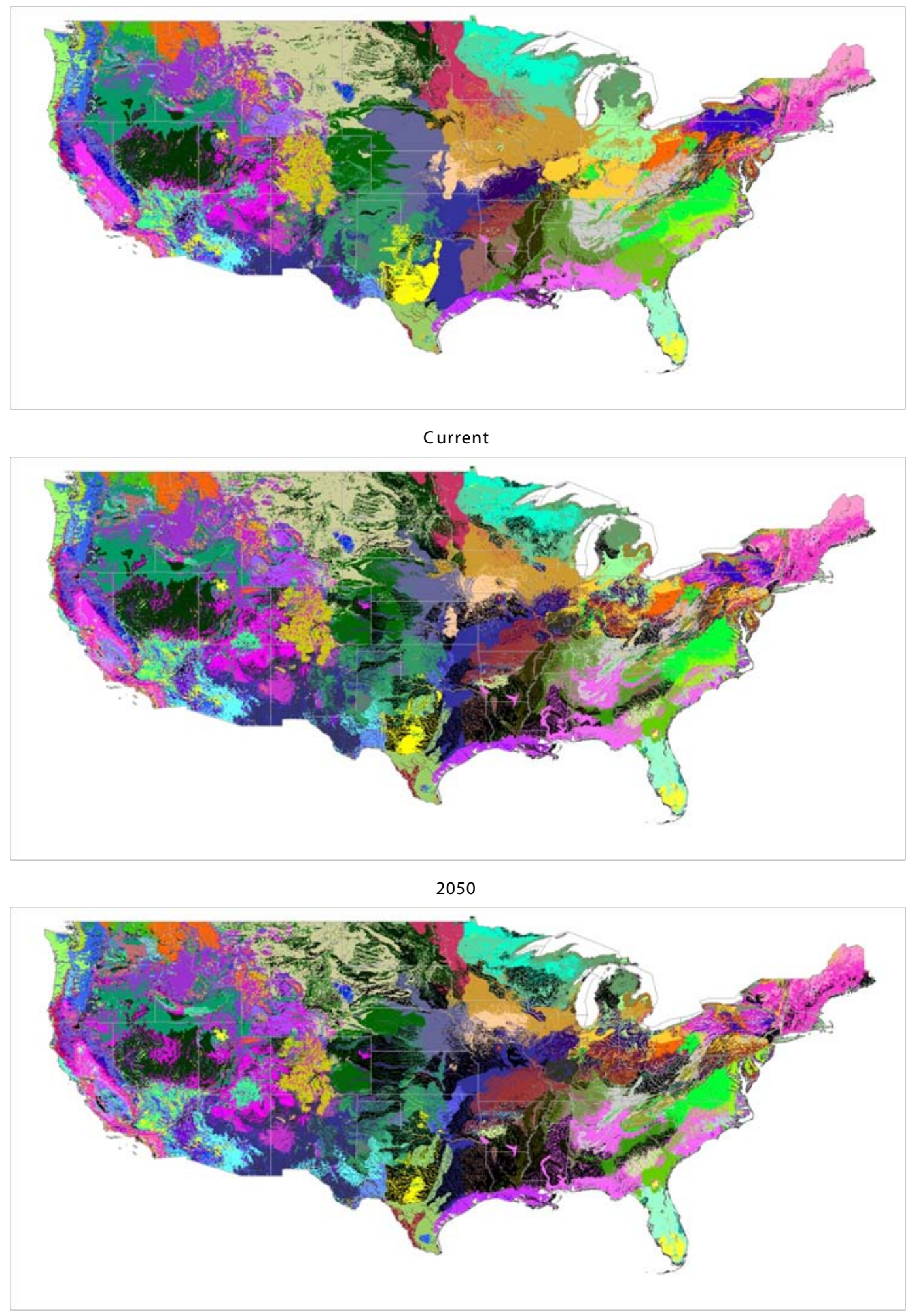

2080

Figure 14. B1 Scenario, Hadley Model; TNC categories. 

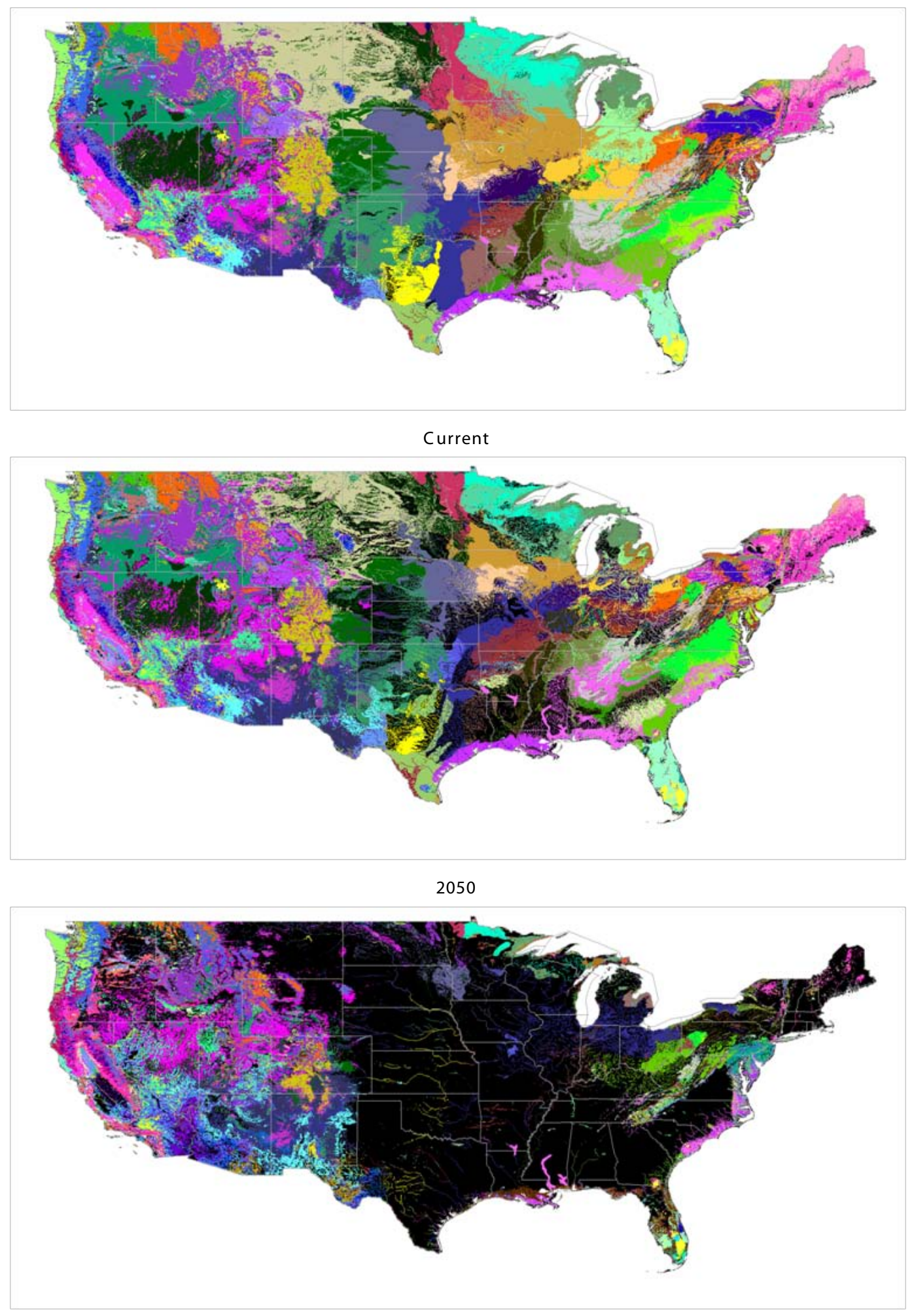

2080

Figure 15. A1 Scenario, Hadley Model; TNC categories. 


\section{Installation Analyses}

\subsection{Step A1: Forecasting installation biome shifts}

In this step, one queries the future maps and asks how individual installations are likely to change, from an ecosystem perspective, over the $21^{\text {st }}$ century. This was done by generating a page of images for each major installation that shows the area around each installation for each of the nine maps, and generating a rank-ordering of installations with respect to significance of change (discussed below). Appendix B (p 36) includes the results for select installations. (Figure 16 shows one example.) The location of an area around the installation is shown against the United States. The remaining maps "zoom into" this area. The map at the top-right shows the current ecosystem types. The middle row shows the images of the same area for the years 2050 and 2080. The columns represent the PCM model, B1 scenario; the PCM model, A1 scenario; the Hadley model, B1 scenario; and the Hadley A1, scenario. The top-left box provides an ecosystem/landcover legend for the most commonly occurring categories across all of the maps on the page.

It is extremely important to read these maps with the following caveats. First, the Hadley and PCM models were chosen to represent relative extremes in GCM forecasts. Similarly, the A1 and B1 gas-emission scenarios provide relative extremes in greenhouse gas emission rates over the $21^{\text {st }}$ century. Secondly, compared with the size of installations, the resolution of the national-scale study is relatively crude. Therefore, on-installation ecosystem details are not captured. Third, the classification of ecosystem type on the installations is likely to be crude - relative to the oninstallation knowledge of local ecologists. Fourth, the forecast change identifies the very long-term steady state of an area. It does not take into account the rate of change to that system, which is mediated by seed dispersal rates, longevity of mature trees, human system management initiatives, susceptibility to disease, and inter-species competition. 


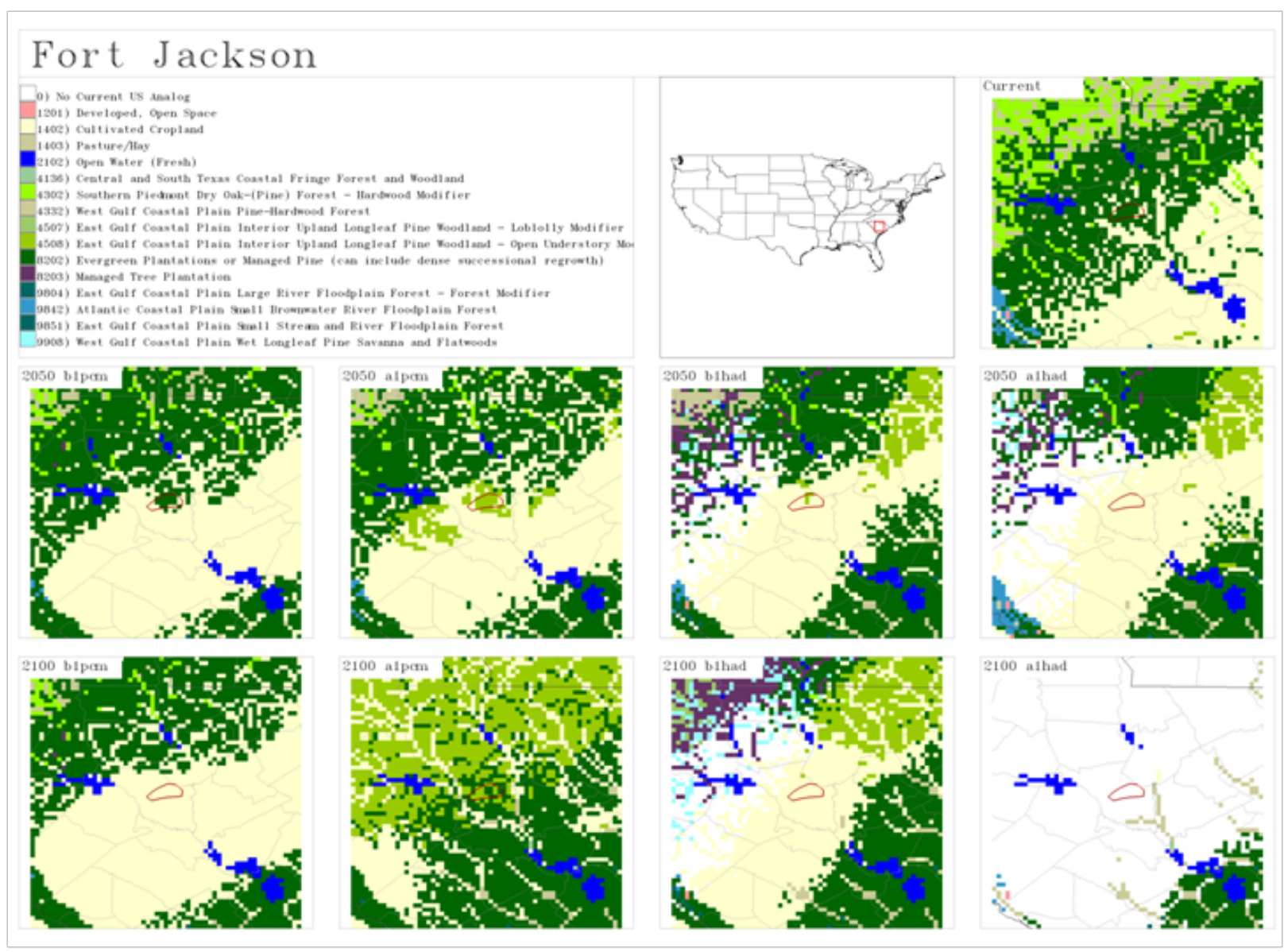

Figure 16. Sample installation report showing local biome shift potentials.

\subsection{Step A2: Find future areas in the present}

Another way to understand the potential for biome shift change and to visualize the relative amount of change is to display where one can go today to find the future ecosystem-driving conditions anticipated in the future. Consider Fort Jackson, SC (Figure 17). The images are arranged similarly to those in Figure 16: Current conditions are at top left, 2050 is the middle row, and 2080 is the bottom row. The first two columns are PCM model results, B1 scenario first and A1 scenario second. The last two columns are Hadley model results, again with B1 the first and A1 the second. The color table runs from dark green through bright green to white, with dark green being identical or very similar to the target. 


\section{Fort Jackson}

These images show where the forecasted physical and climate conditions most closely match the conditions found across the region in 2000. This answers the question, "Where can I go today to find the forecasted conditions for this installation?"
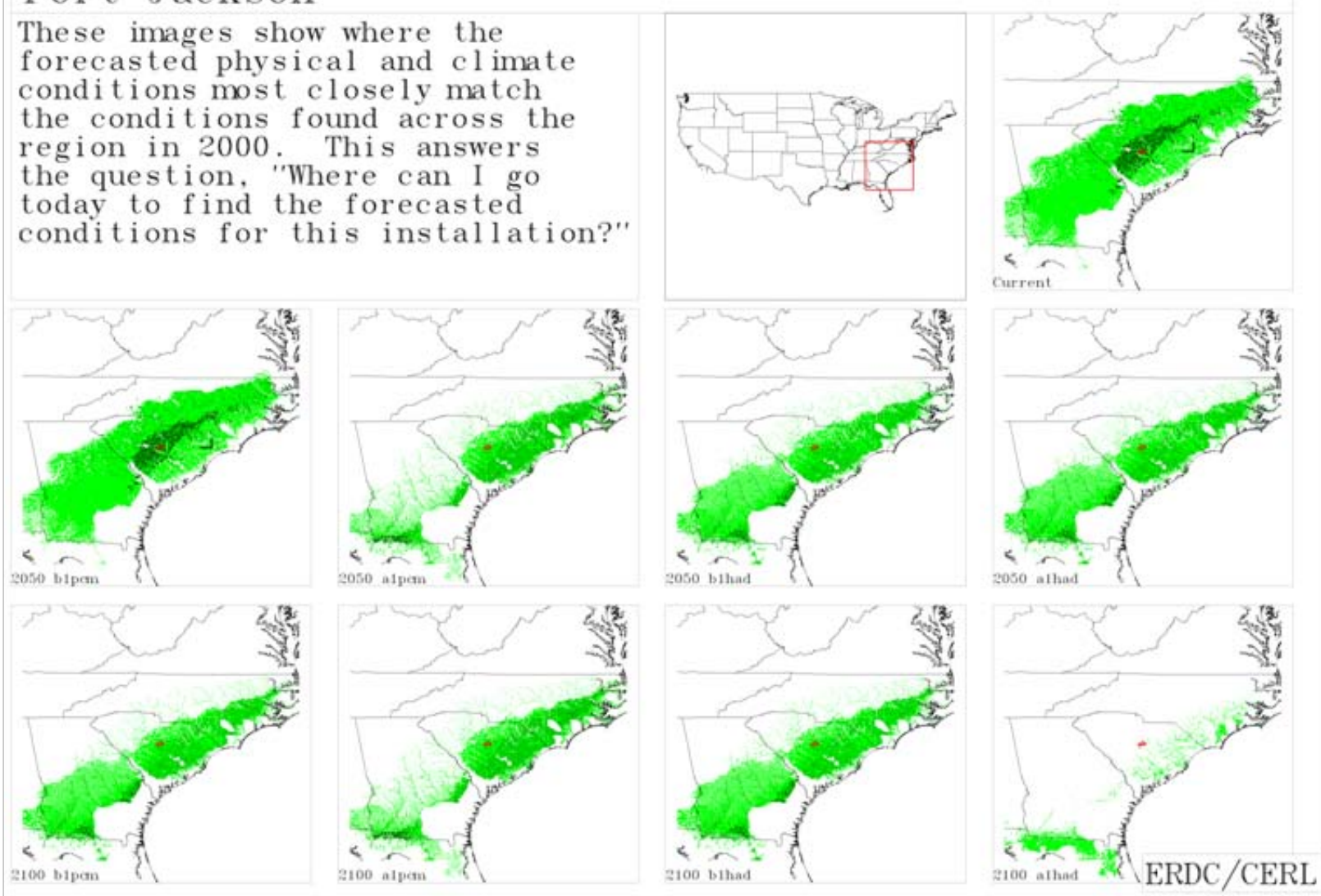

Figure 17. Current location of forecast ecosystem conditions.

The PCM B1 scenario suggests little change for this area by 2050. To find the best current example of conditions estimated for 2080 one needs to travel to the east area in Georgia. The Hadley A1 panel suggests that there are no areas that one can currently go today to find the conditions anticipated for Fort Jackson in 2080, but that the Florida panhandle offers the best analog. The gross graphical suggests that one need move further and further south to find areas that are similar to the modeled futures. Appendix B to this report (p 36) includes panels for selected installations.

\subsection{Step A3: Rank areas by degree of change}

Which installations are most at-risk for change due to the consequences of potential ecosystem shift? To rank-order installations, the boundary of each installation was used to "cookie-cutter" into the current and future maps over the eight future GAP-based maps to tabulate the ecosystem type and amount of each type. For each future map, the percent of the installa- 
tion that still held the current ecosystem types was calculated. The percentage across all eight future maps was then averaged and used to rankorder the installations. Appendix C (p 116) lists all of the Army installations beginning with the least changeable and ending with the installations likely to be most dramatically affected. The last column (on which the table is sorted) lists the average of the counts of changes for each model/scenario/time combination.

\subsection{Step A4: Looking at raw change across CONUS}

Another way to view the data is to simply look for degree of change over time across the 16 ecological drivers. Remember that each of the driver maps encodes the number of standard deviations from each map's average for each gridcell. Consider that these 16 values represent coordinates in a 16-dimensional space. One way to calculate overall change is to find the straight-line distance using the Pythagorean theorem between the 16-D coordinate for a space in 2000 and the 16 -D coordinate representing a later time. This method assumes that one unit of change in one dimension is equivalent to one unit of change in every other dimension.

Figures 18 to 21 each show the two time steps (2050 and 2080) for each of the four model/scenario combinations. The images use a grey-scale color table with areas that change little in white and those that change a lot in black. Each image uses the same color table to allow for easy visual comparison. As expected, the Hadley model is consistently associated with greater change than the PCM model. Also, the higher emission scenario (A1) is associated with across the board greater change. In every map, the degree of change is quite variable across the nation, and the patterns of change are different across models and scenarios. 

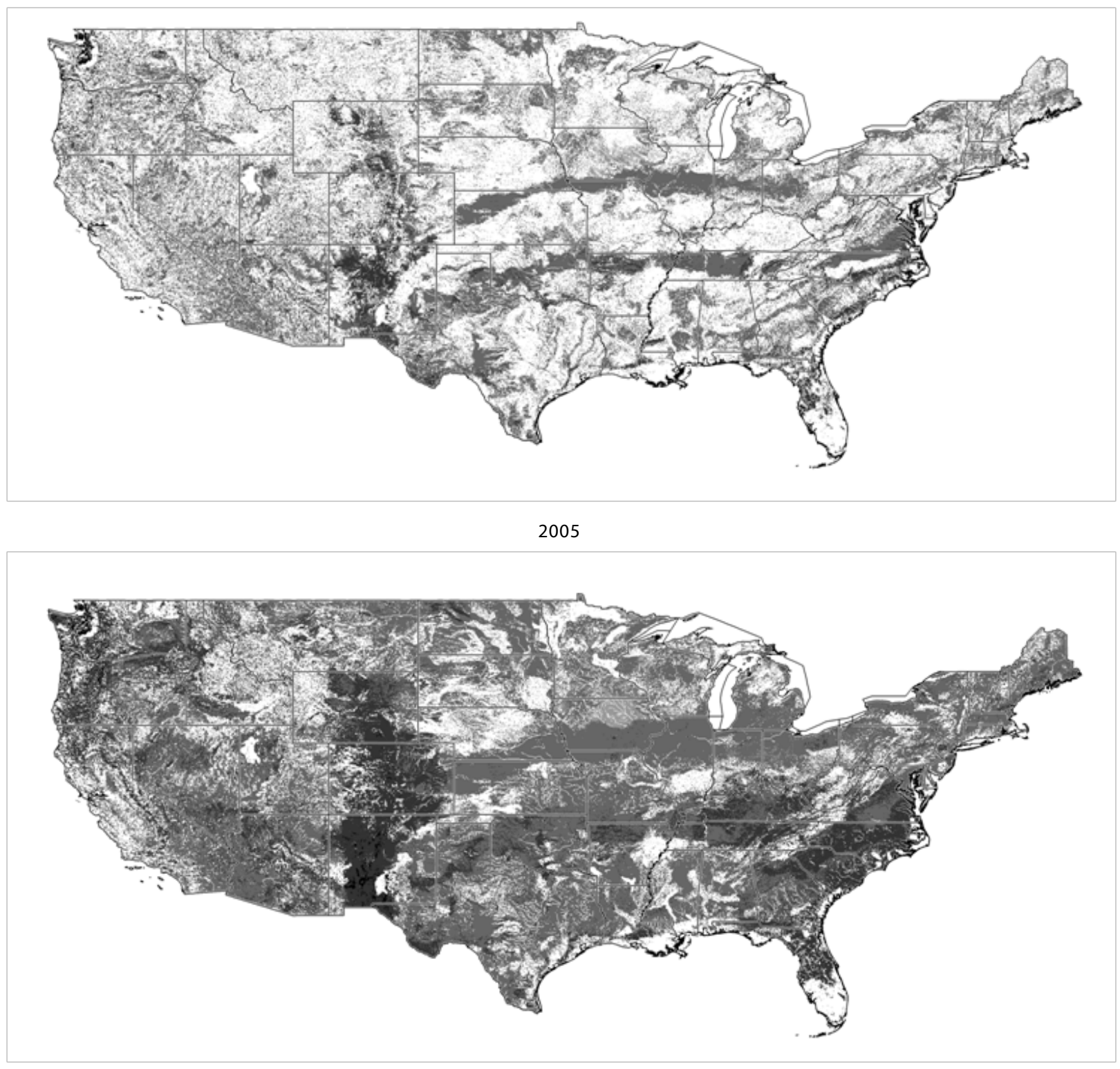

2080

Figure 18. Degree of change. Model: PCM, Scenario: A1. 

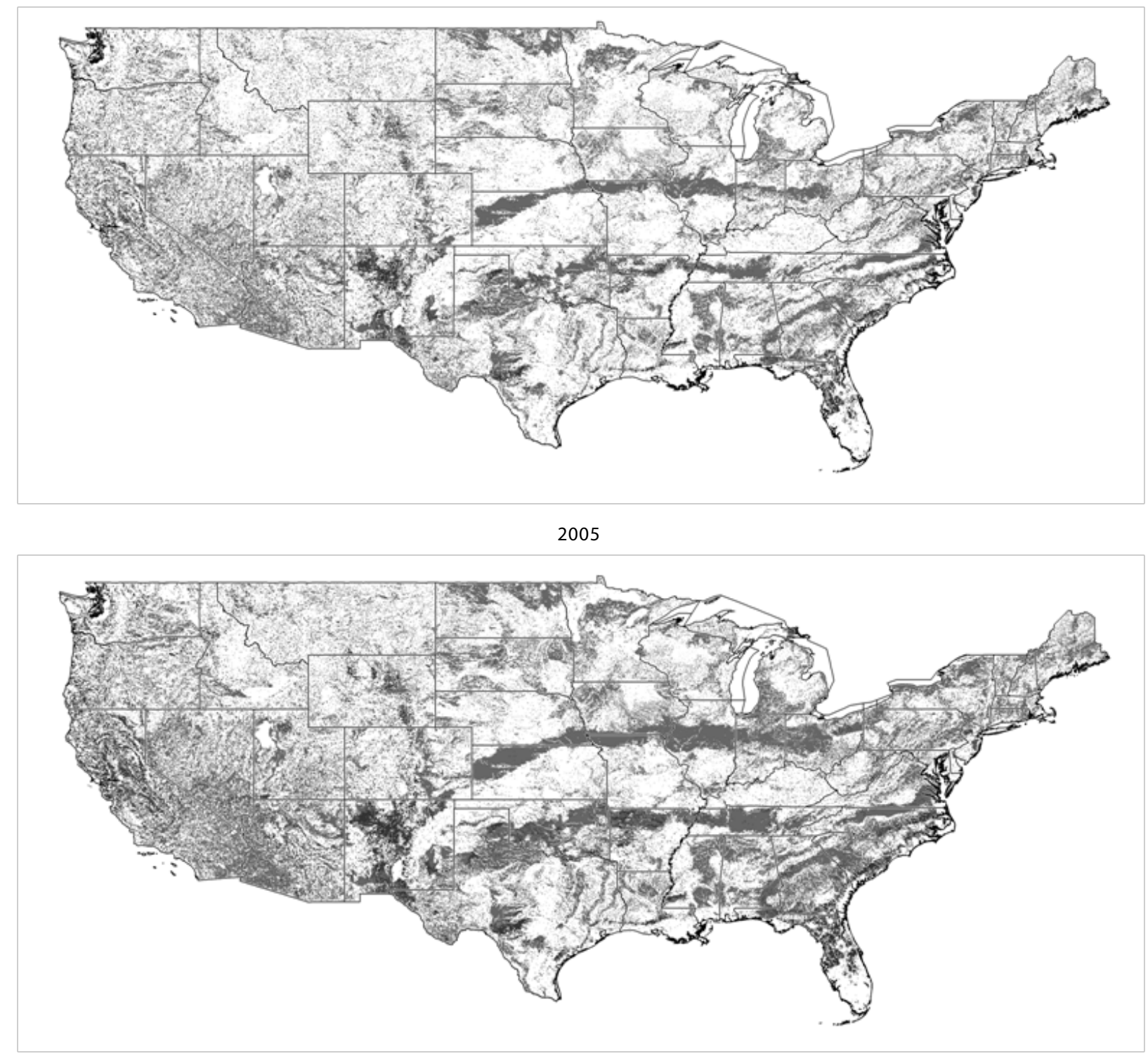

2080

Figure 19. Degree of change. Model: PCM, Scenario: B1. 

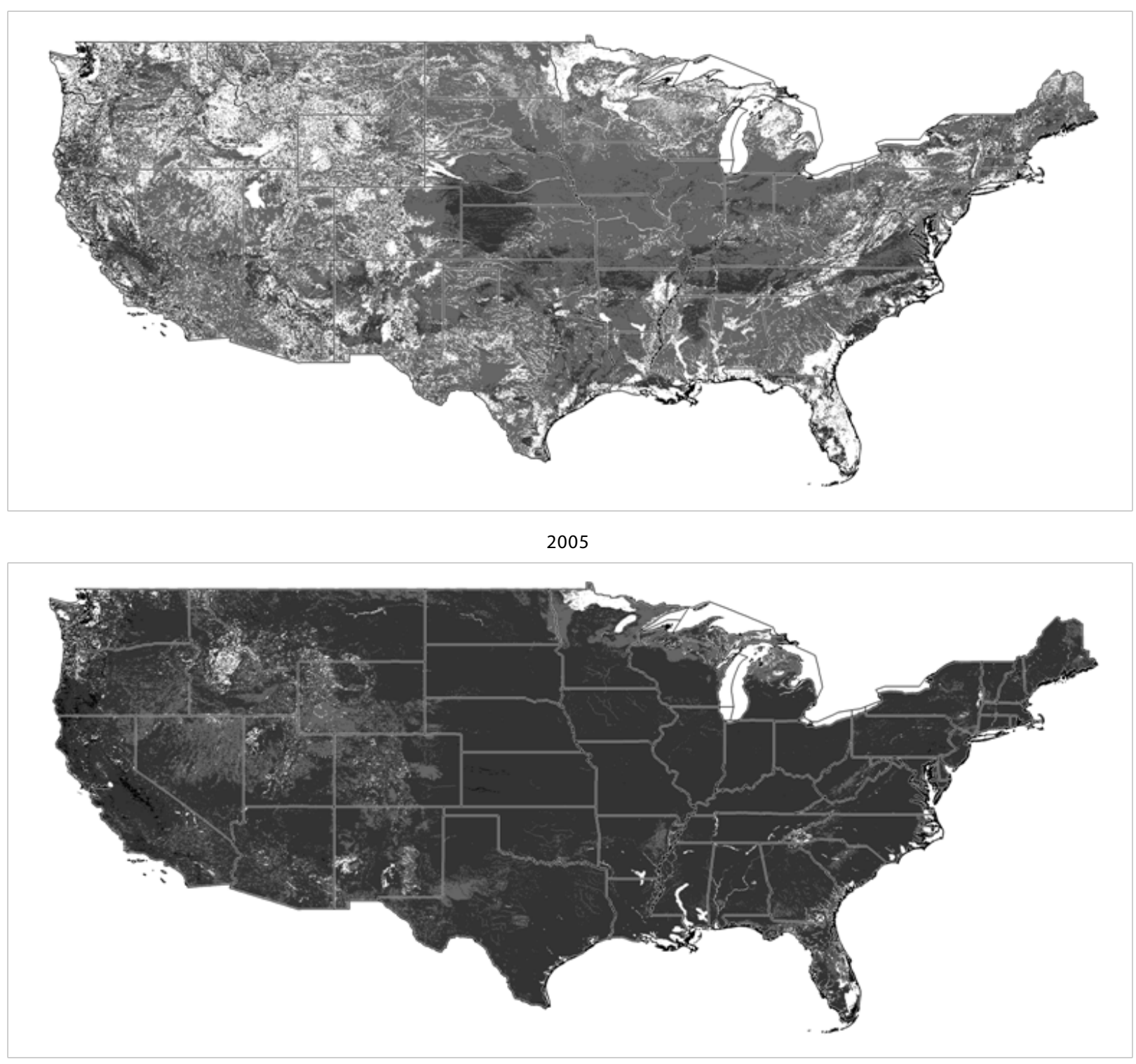

2080

Figure 20. Degree of change. Model: Hadley, Scenario: A1. 

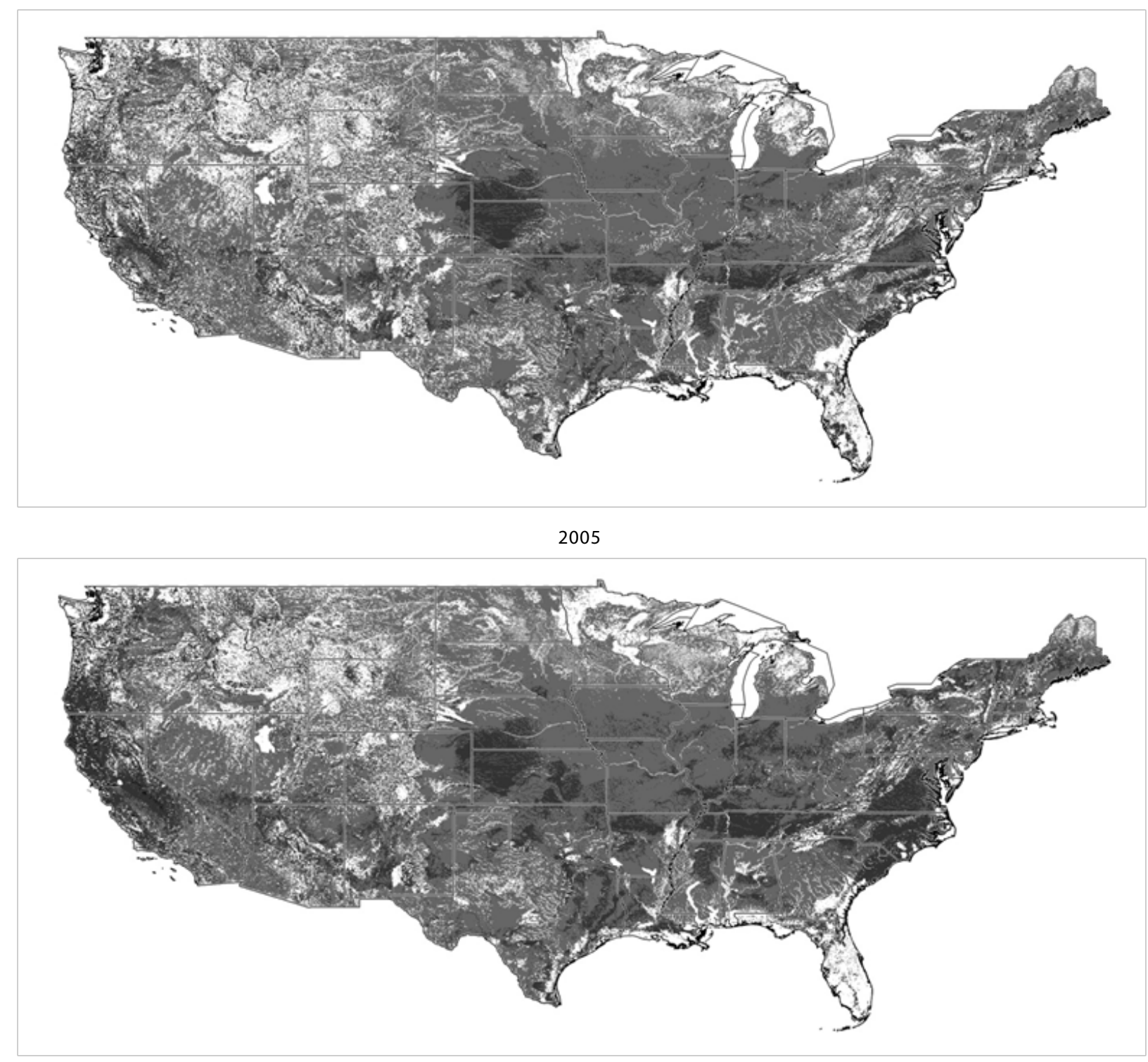

2080

Figure 21. Degree of change. Model: Hadley, Scenario: B1. 


\section{Conclusions}

This work has addressed three questions regarding the anticipated implications of forecast climate change in the CONUS for US Army installations.

\section{1 "Which installations are most at-risk with respect to ecosystem changes?"}

This work investigated the potential for ecosystem shifts on 134 military installations and tabulated the percent of anticipated shift in Appendix C (p 116). That potential was estimated for all eight combinations of two GCMs (Hadley, a model that tends to predict significant change; and PCM, a model that predicts less severe change), two scenarios (A1, higher carbon emissions, and B1, lower emissions), and two time periods. This work concludes that the major training/testing installations that appear to be most at risk include:

- Yakima

- Fort Huachuca

- Fort Drum

- Fort Hunter-Liggett

- Fort Jackson

- Fort Knox

- Fort Bliss

- Fort Sill

- Fort Campbell

- Fort Gordon

- Fort Benning.

\subsection{What is the range of anticipated ecosystem shifts based on the forecasts of general circulation models (GCMs)?}

The two GCMs chosen represent a reasonable range of climate condition change forecasts. The models generally agreed in the direction of system changes, varying only in degree. Based on this analysis, 66-88 percent of installations are expected to see ecosystem driver conditions (weather, soils, and insolation) change enough by 2050 to support a different system than now exists. By 2080 that range shifts to 68-99 percent. By this anal- 
ysis, this work concludes that over the coming decades, most installations are expected to see clear evidence of climate change impact on the types of plants and animals that naturally thrive on their lands.

\subsection{Where can one go today to find the ecosystem drivers (weather, climate, soil, and sun) anticipated in the future?}

Appendix B to this report ( $\mathrm{p}$ 36) includes three panels of analysis results for some of the largest Army training and testing installations. The third panel in each set maps where one might go today to find the ecosystem driver conditions that most closely match the anticipated future conditions for the installation. In general one must travel south, or down-slope, to find the anticipated future conditions today. However, in the long term, it becomes increasingly likely that there is no nearby location that is like the anticipated future.

As noted earlier, this analysis looks only at the anticipated changing conditions that support ecosystems and that matches future conditions to current conditions to see what ecosystems are currently supported by specific combinations of conditions. While this analysis might predict what ecosystems might emerge in the future if conditions were to stabilize, it absolutely does not forecast when the new system will replace the current system. However, this analysis does suggest that across CONUS there will be a long-term mismatch between extant systems and the conditions upon which those systems depend. Ecological models may become useful for forecasting change rate and process, but the consequences of these changes will be the subject of study for many decades to come. 


\section{Acronyms and Abbreviations}

$\begin{array}{ll}\text { Term } & \text { Definition } \\ \text { BRD } & \text { Biological Resources Discipline } \\ \text { CEERD } & \text { U.S. Army Corps of Engineers, Engineer Research and Development Center } \\ \text { CERL } & \text { Construction Engineering Research Laboratory } \\ \text { CONUS } & \text { Continental United States } \\ \text { DC } & \text { District of Columbia } \\ \text { ERDC } & \text { Engineer Research and Development Center } \\ \text { GAP } & \text { Gap Analysis Program } \\ \text { GCM } & \text { general circulation model } \\ \text { GIS } & \text { geographic information system } \\ \text { MGC } & \text { Multivariate Geographic Clustering } \\ \text { NCAR } & \text { National Center for Atmospheric Research } \\ \text { PCM } & \text { Parallel Climate Model } \\ \text { POP } & \text { Parallel Ocean Program } \\ \text { TNC } & \text { The Nature Conservancy } \\ \text { TR } & \text { Technical Report } \\ \text { URL } & \text { Universal Resource Locator } \\ \text { US } & \text { United States } \\ \text { USGS } & \text { U.S. Geological Survey } \\ \text { WWW } & \text { World Wide Web }\end{array}$




\section{References}

Bailey, R. G. 1983. Delineation of ecosystem regions. Environmental Management. 7:365-373.

Dai, A., G. A. Meehl, W. M. Washington, T. M. L. Wigley, and J. M. Arblaster. 2001. Ensemble simulation of twenty-first century climate changes: Business-as-usual versus $\mathrm{CO}_{2}$ stabilization. Bull. Amer. Meteor. Soc. 82:2377-2388.

Davidson, A. 2010. National Land Cover Developments. Gap Analysis Bulletin No. 17. USGS/BRD/Gap Analysis Program, Moscow, ID, http://www.gap.uidaho.edu/bulletins/17/Davidson.pdf

GAP. 2011. Welcome to the GAP Analysis Program (GAP) Land Cover Viewer. Webpage, http://www.gap.uidaho.edu/landcoverviewer.html

Hargrove, W. M. and F. W. Hoffman. 2005. Potential of Multivariate Quantitative Methods for Delineation and Visualization of Ecoregions. Environmental Management. 34(1): S39-S6o

Hijmans, R.J., S.E. Cameron, J.L. Parra, P.G. Jones and A. Jarvis. 2005. Very high resolution interpolated climate surfaces for global land areas. International Journal of Climatology 25:1965-1978

IPCC. 2001. Climate Change 2001: The Scientific Basis. Contribution of Working Group I to the Third Assessment Report of the Intergovernmental Panel on Climate Change. Cambridge, UK and New York, NY: Cambridge University Press.

Smith, R. D., J. K. Dukowicz, and R. C. Malone. 1992. Parallel ocean general circulation modeling. Physica D. 60:38-61.

Wood, R. A., A. B. Keen, J. F. B. Mitchell, and J. M. Gregory. 1999. Changing spatial structure of the thermohaline circulation in response to atmospheric $\mathrm{CO} 2$ forcing in a climate model. Nature, 399:572-575. 


\section{Appendix A: Legends}


1201) Developed, Open Space

1202) Developed, Low Intensity

1203) Developed, Medium Intensity

1204) Developed, High Intensity

1402) Cultivated Cropland

1403) Pasture/Hay

2102) Open water (Fresh)

2103 ) Open water (Erackish/Salt)

$3105)$ Undifferentiated Barren Land

3111) North American warm Desert Active and Stabilized Dune

3116) Great Lakes Dune

3121) Inter-Mountain Basins Active and Stabilized Dune

3201 North American Warm Desert Bedrock Cliff and Outcrop

3202) Rocky Mountain Cliff, Canyon and Massive Bedrock

$320.3)$ western Great Plains Cliff and Outcrop

3204) Great Lakes Acidic Rocky Shore and Cliff

3209) North Pacific Montane Massive Bedrock. Cliff and Talus

3216) Inter-Mountain Basins $\mathrm{Cliff}$ and Canyon

3218) Colorado Plateau Mixed Bedrock Canyon and Tableland

3301 ) western Great Plains Badland

3405) North American Warm Desert Playa

$3407)$ Inter-Mountain Basins Playa

3501 ) North Pacific Alpine and Subalpine Bedrock and Scree

3502) North American Alpine loe Field

3503 ) Rocky Mountain Alpine Bedrock and Scree

3504) Mediterranean California Alpine Bedrock and Scree

$3605)$ North American warm Desert Pavement

3607) North American Warm Desert Volcanic Rockland

4101) Central and Southern Appalachian Northern Hardwood Forest

4104) Northeastern Interior Dry Oak Forest-Hardwood Modifier

4109) Southern and Central Appalachian Oak Forest - Xeric

4110) North Pacific Oak woodland

4111) Rocky Mountain Aspen Forest and woodland

4113) Laurentian-Acadian Northern Hardwoods Forest

4114) Northeastern Interior Dry-Mesic Oak Forest

4115) Ozark-Ouachita Dry-Mesic Oak Forest

4116) Southern Interior Low Plateau Dry-Mesic Oak Forest

4118) Crosstimbers Oak Forest and Woodland

4120) North-Central Interior Dry-Mesic Oak Forest and woodland

4124) North-Central Interior Maple-Basswood Forest

4125) Southern and Central Appalachian Oak Forest

4126) Al legheny-Cumber land Dry Oak Forest and Woodland - Hardwood

4133) Atlantic Coastal Plain Dry and Dry-Mesic Oak Forest

4136) Central and South Texas Coastal Fringe Forest and woodland

4140) East-Central Texas Plains Post Oak Savanna and woodland
4141) East-Central Texas Plains Riparian Forest

4143) Madrean Encinal

1443) Mediterranean California Mixed Oak Woodland

4147) Inter-Mountain Basins Curl-lear Mountain Mahogany wodland and Shrubland

4152) Edwards Plateau Limestone Sovanna and woodland

4201) Boreal Aspen-Birch Forest

4204) West Gulf Coastal Plain Mesic Hardwood Forest

4207) Ozark-Ouachi to Mesic Hardwood Forest

4212) Atlantic Coastal Plain Southern Maritime Forest

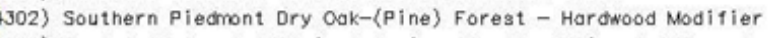

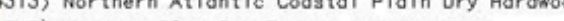

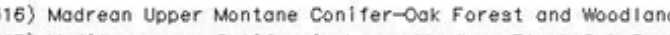

Forest and Woodland

18) Mediterranean California Red Fir Fores

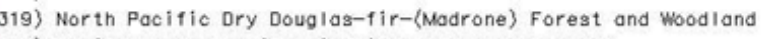

4320) Mediterranean California Mixed Evergreen Fores

4324) Inter-Mountain Basins Aspentaixed Conifer Forest and woodland

4326) Boreal white Spruce-fir-Hardwood Forest

4327) Laurentian-Acadian Pine-Hemlock-Hardwood Forest

4328) Ozark-Ouachi to Shortleaf Pine-Oak Forest and woodland

4330) Central Appalachian Oak and Pine Forest

4331) Appalachian Hemlock-Hardwood Forest

4332) West Gulf coastal Plain Pine-Harowood Forest

4333) Acadian Low-Elevation Spruce-Fir-Hardwood Forest

4334) Southern Ridge and Valley Dry Calcareous Foreat

4335) Central Appalachian Pine-Oak Rocky Woodland

4338) North Pacific Lowland Mixed Hardwood-Conifer Forest and Woodland

$4401)$ Southern and Central Appalachian Cove Forest

4402) South-Central Interior Mesophytic Forest

4404) Mediterranean California Mesic Serpent ine woodland and Chaparral

4501) East Gulf coastal Plain Interior Upland Longleaf Pine Woodland - offsite Hardwood Modifier 4507) East Gulf coastal Plain Interior Upland Longleat Pine Woodland - Loblolly Modifler

East Gulf Coastal Plain Interior Upland Longleaf Pine Woodland - Open Understory Modifier

4511) Central and Southern California Mixed Evergreen woodland

4512) Colorado Plateau Pinyon-Juniper woodland

4514) Great Bas in Pinyon-Juniper Woodian

4518) Madrean Pinyon-Juniper Woodland

(and woodland

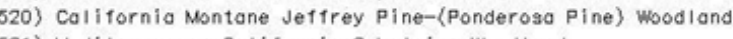

521) Mediterranean California Subalpine Woodland

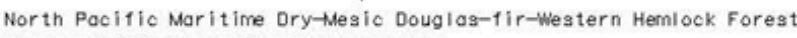

4523) Nor th Pacific Mountain Hemlock Forest

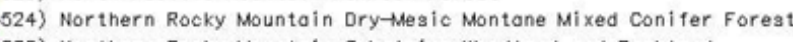

(525) Northern Rocky Mountain Subalpine woodland and Parkland

(25) Rocky Mountain Foothili Linber Pine-Juniper Woodlon

(52)

Mixed Conifer Forest and Woodland

)

(5) Southern Rocky Mountain Ponderosa pine woodland

作

Pine woodiand

4533) Sierra Nevadg Subalpine Ladgepole Pine Forest and woodland

Figure A1. Legend for GAP maps. 
182) $47 \%$-North Atlantic Coast

183) $61 \%$-North Central Tillplain

184) $53 \%$-Northern Appalachian / Acadian

185) $76 \%$-Ouachita Mountains

186) $94 \%$-Ozarks

187) $31 \%-P i e d m o n t$

188) $53 \%$-Prairie-Forest Border

189) $94 \%$-Southern Blue Ridge

269) $54 \%$-Southern Shortgrass Prairie

355) $74 \%$-Tropical Florida

423) $92 \%$-Valdivian Temperate Forests

431) $70 \%$-Uruguayan Savanna

432) $56 \%$-Espinal

434) $37 \%$ - Low Monte

452) $45 \%$-Chilean Matorral

496) $38 \%$-California North Coast

497) $37 \%$-Canadian Rocky Mountains

498) $57 \%$-East Cascades - Modoc Plateau

499) $90 \%$-East Gulf Coastal Plain

500) $33 \%$-Florida Peninsula

502) $33 \%$ - KI amath Mountains

503) $81 \%$-Mid-AtIantic Coastal Plain

573) $27 \%$-Zagros Mountains Forest Steppe

610) $25 \%$-Eastern Anatolian Montane Steppe

667) $78 \%$-Mediterranean Dry Woodlands And Steppe

668) 36\% -Mediterranean Woodlands And Forests

673) $85 \%$-Baluchistan Xeric Woodlands

679) 52\% -Central Persian Desert Basins

693) 64\% -Registan-North Pakistan Sandy Desert

705) $56 \%$-Central Appalachian Forest

706) $56 \%$-Chesapeake Bay Lowlands

707) $30 \%$-Cumberlands And Southern Ridge And Valley

708) $78 \%$-Great Lakes

709) $58 \%$ - High Al legheny Plateau

10) $38 \%$-Interior Low Plateau

711) $73 \%$-Lower New England / Northern Piedmont

712) $61 \%$-Mississippi River Alluvial Plain

714) $99 \%$-Superior Mixed Forest
715) $31 \%$-Upper East Gulf Coastal Plain

716) $44 \%$-Western Al legheny Plateaw

718) $41 \%$-Arizona-New Mexico Mountains

720) $35 \%$-Middle Rockies - Blue Mountains

721) $79 \%$-Montane Cordillera

723) $25 \%$-Okanagan

724) $29 \%$-Pacific Nor thwest Coast

726) $27 \%$ - Sierra Nevada

727) $82 \%$-South Atlantic Coastal Plain

728) $40 \%$-Southern Rocky Mountains

729) $84 \%$-Upper West Gulf Coastal Plain

731) $40 \%$-Utah-Wyoming Rocky Mountains

732) $51 \%$-West Cascades

733) $97 \%$-West Gulf Coastal Plain

738) $77 \%$-Boreal Shield

746) $100 \%$-Gulf Coast Prairies And Marshes

747) $67 \%$-Aspen Parkland

748) $86 \%$-Central Mixed-Grass Prairie

749) $71 \%$-Central Shortgrass Prairie

750) $48 \%$-Central Tallgrass Prairie

751) $72 \%$-Crosstimbers And Southern Tallgrass Prairie

752) $51 \%$-Dakota Mixed-Grass Prairie

753) $53 \%$-Edwards Plateau

754) 69\% -Fescue-Mixed Grass Prairie

755) $90 \%$-Northern Great Plains Steppe

756) $74 \%$-Northern Tallgrass Prairie

757) $90 \%$-Osage Plains/Flint Hills Prairie

760) $98 \%$-California Central Coast

762) $37 \%$-Great Central Valley

763) $71 \%$-Apache Highlands

765) 30\% -Chihuahuan Desert

766) $59 \%$-Colorado Plateau

767) $70 \%$-Columbia Plateau

768) $73 \%$-Great Basin

770) $45 \%$-Sonoran Desert

771) 53\% -Tamaul ipan Thorn Scrub

772) $60 \%$-Wyoming Basins

806) 50\% -Central Ranges Xeric Scrub

Figure A2. Legend for TNC maps. 


\section{Appendix B: Installation Biome Shift Forecasts}

Installations are alphabetically ordered on the following pages:

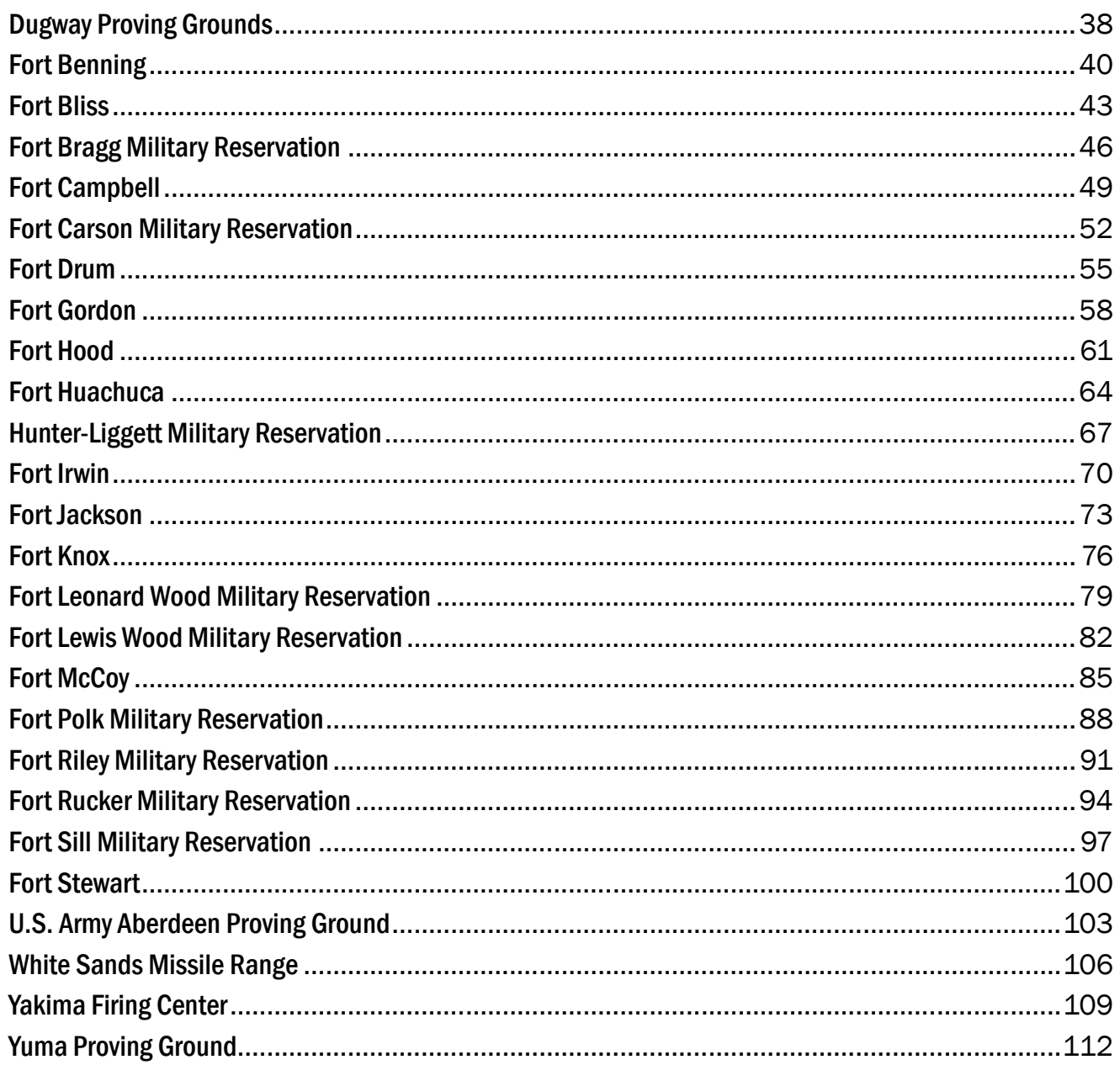

Each installation is illustrated with three panels:

1. A series of current and future GAP-analysis maps.

2. A series of current and future TNC-analysis maps.

3. A series of maps showing where, today, one might go to find the future forecast conditions. 
For each page, the location of an area around the installation is shown against the United States. The remaining maps "zoom into" this area. The map at the top-right shows the current ecosystem types. The middle row shows the images of the same area for 2050 and 2080 . The columns represent the PCM model, B1 scenario; the PCM model, A1 scenario; the Hadley model, B1 scenario; and the Hadley A1, scenario. The top-left box for the GAP and TNC images provides an ecosystem/land-cover legend for the most commonly occurring categories across all of the maps on the page. 


\section{Dugway Proving Grounds}

Dugway Proving Grounds

6309) Inter-Mountain Basins Seni-Desert Shrub Steppe

saos) Cofifornia Lower Montane Blue Oak-Foothill Pine Noodl and and Savann

5601) Colorado Plateau Pinyon-Juniper Strubland

- 5706) Inter-Mountain Basins Big Sagebrush Shrubland

5707) Southern colorado Plateau Sand Shrublan

7203) Northern Rocky Mountain Lower Montane. Foothill and Valley Grassland

7304) Columbia Basin Foothill and Canyon Dry Grassla

- 7305) Inter-Mountain Basins Seni-Desert Grassland

7306) Nor thwestern Great Plains Mixedgrass Pra

7501) California Central Valley und Southere Cosal Graselom

B304) Recently burned shrubland

8404) Introduced Cpland Vegetation - Annual Grassland
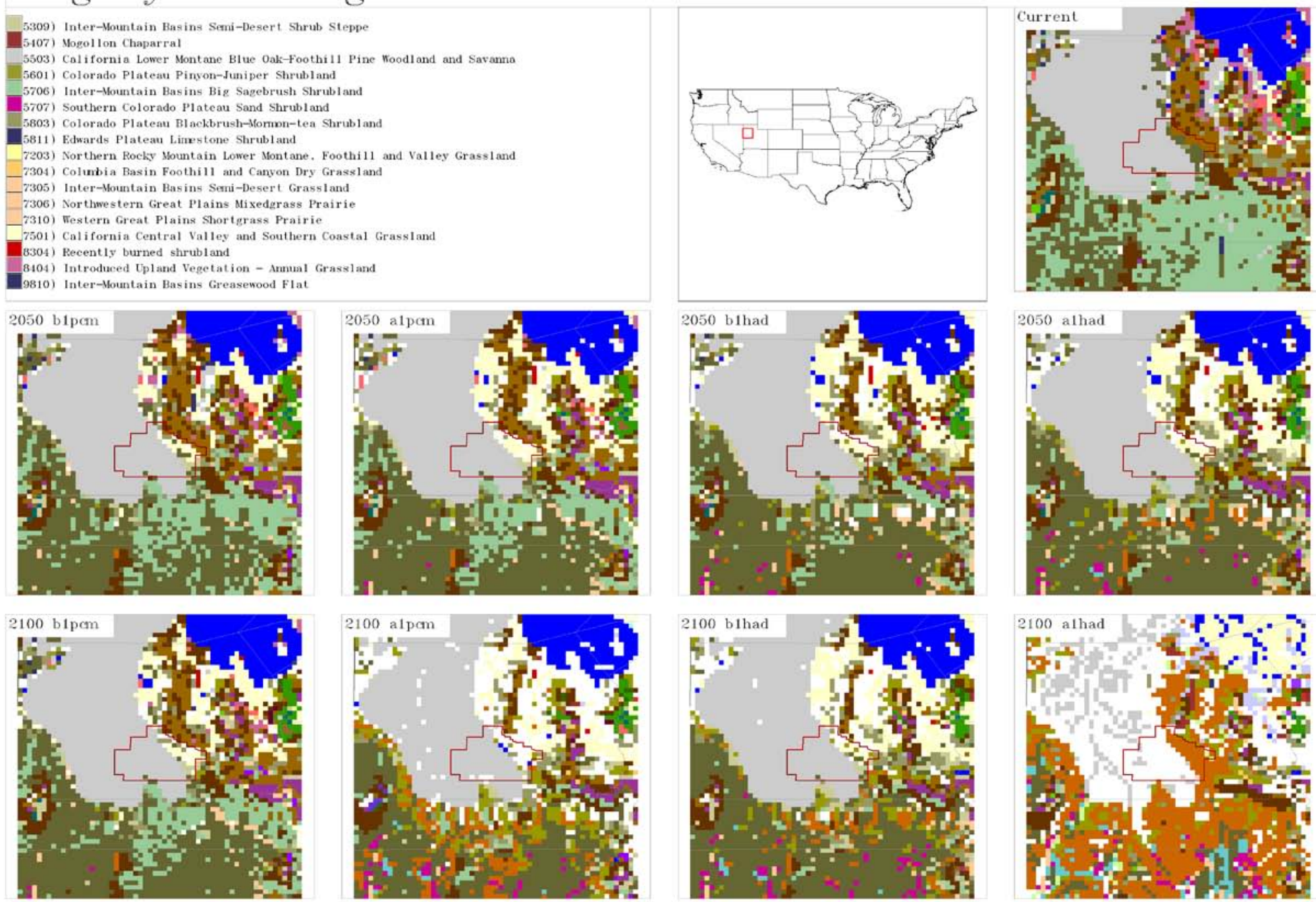
Dugway Proving Grounds
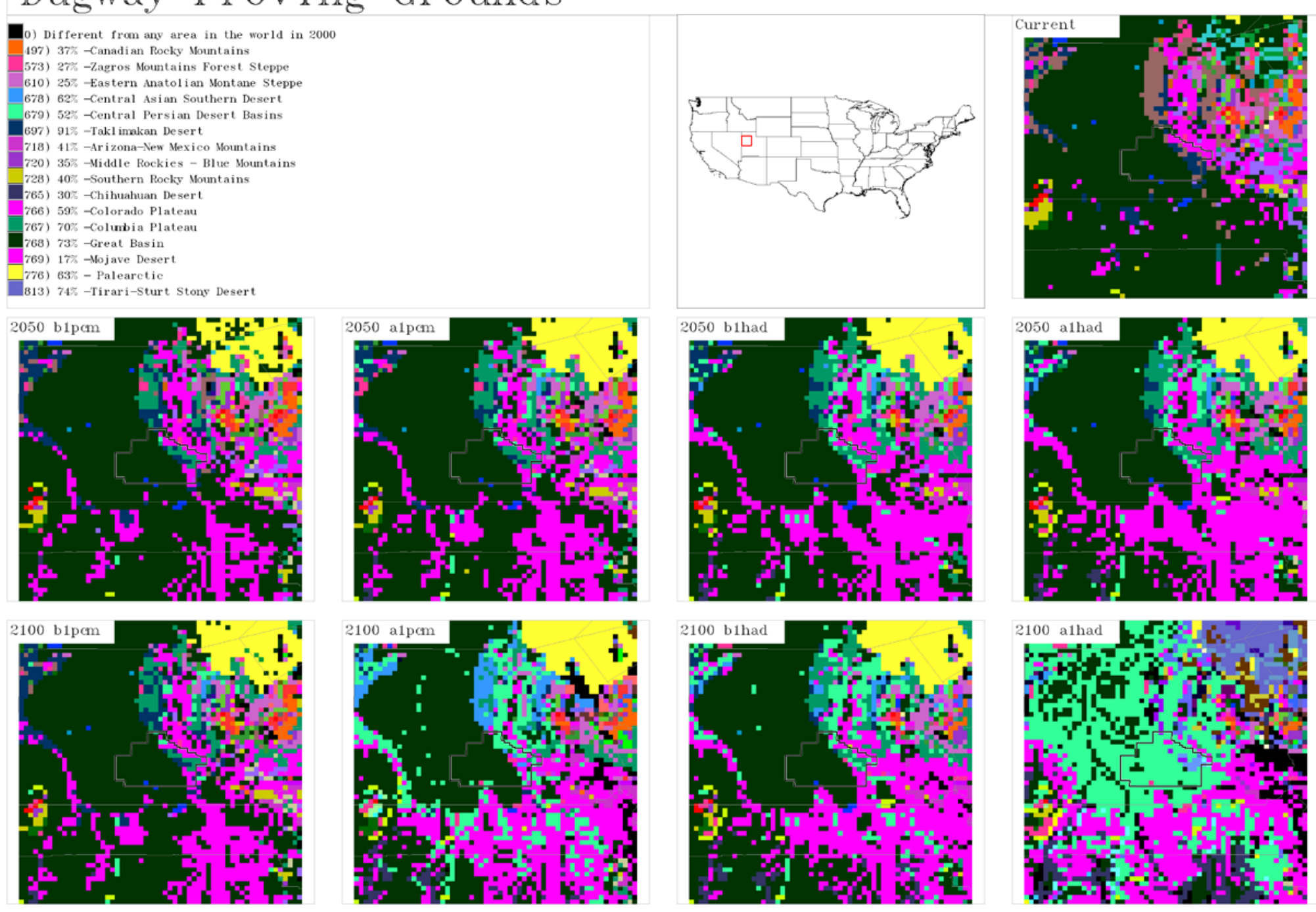
Dugway Proving Grounds These images show where the forecasted physical and climate conditions most closely match the conditions found across the region in 2000. This answers the question, "Where can I go today to $f$ ind the forecasted conditions for this installation?"
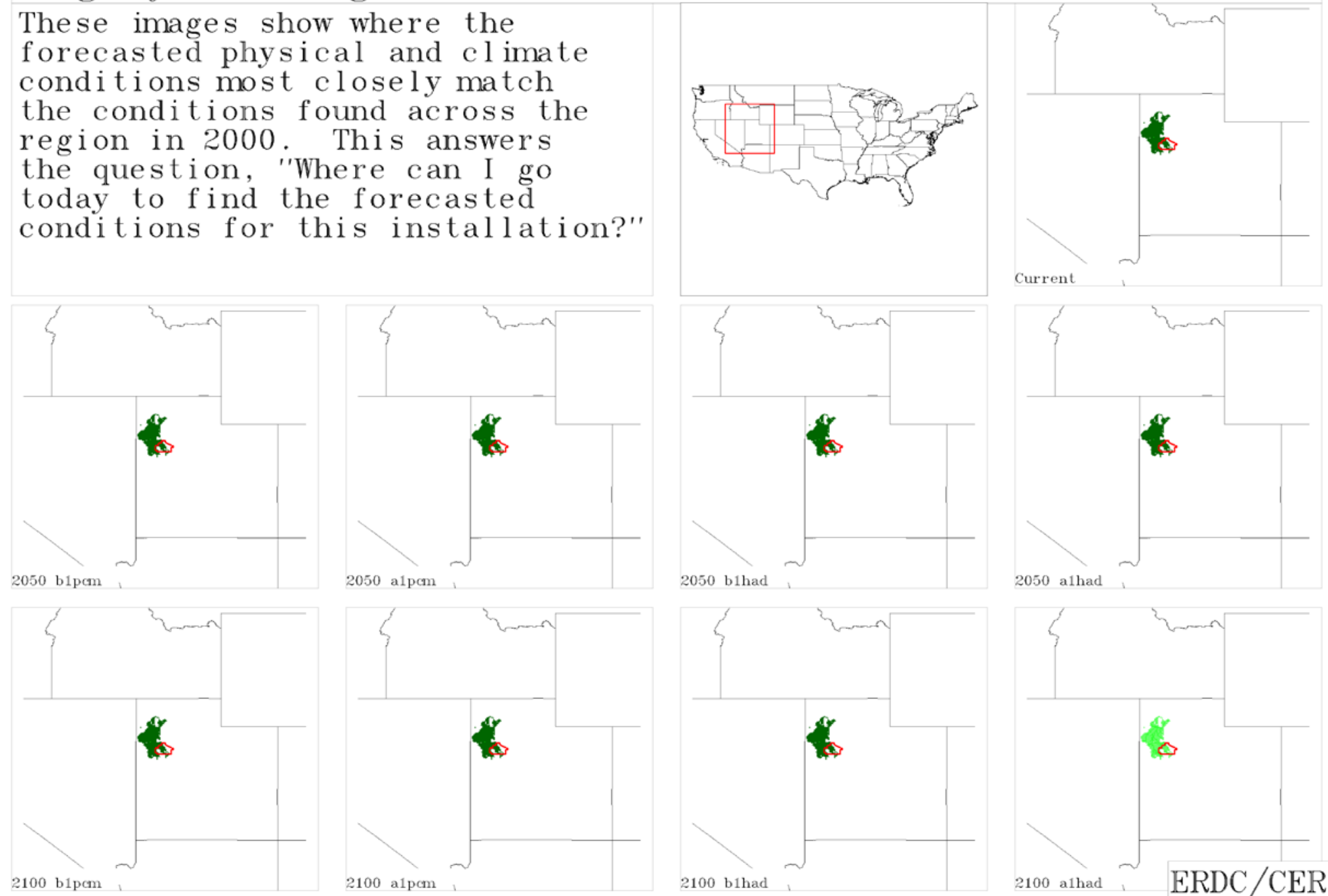

$2100 \mathrm{~b} 1 \mathrm{pcm}$
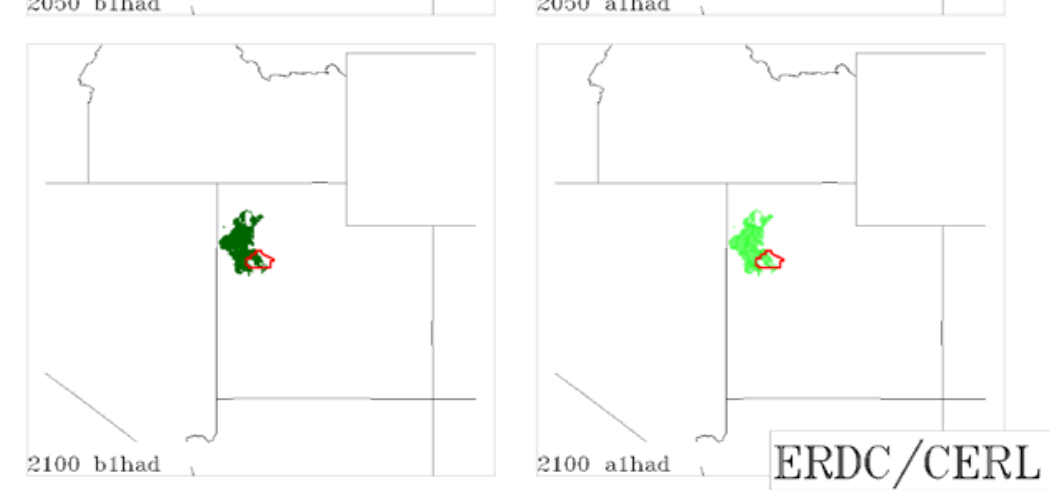

Fort Benning 
Fort Benning Military Reservation

0) No Current US Analog

1402) Cultivated Cropland

1403) Pasture/Hay

2102) Open Water (Fresh)

4302) Southern Piedmont Dry Oak-(Pine) Forest - Hardwood Mo

4334) Southern Ridge and Valley Dry Calcareous Forest

1507) East Gulf Coastal Plain Interior Upland Longleaf Pine

8202) Evergreen Plantations or Managed Pine (can include de

8203) Managed Tree Plantation

9851) East Gulf Coastal Plain Small Stream and River Floodp

9908) West Gulf Coastal Plain Wet Longleaf Pine Savanna and
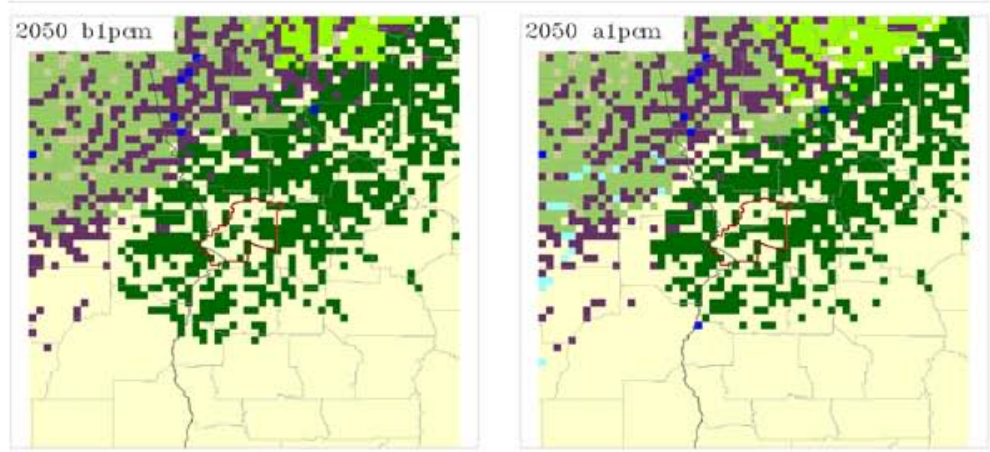

2100 b1pm 다.

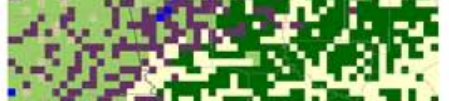

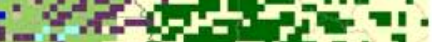

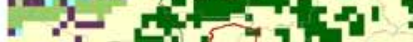

$\therefore$

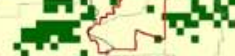

. 8 : :

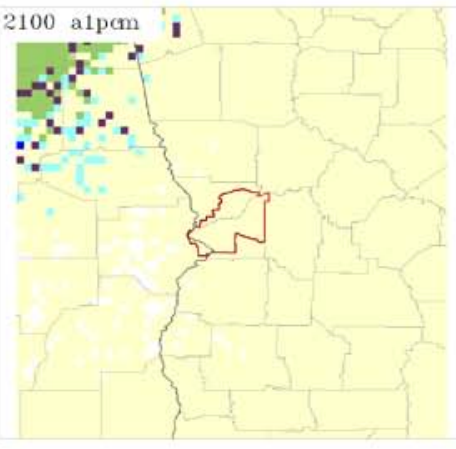

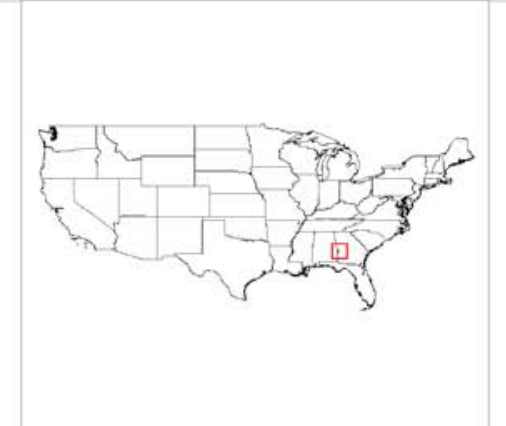

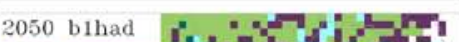
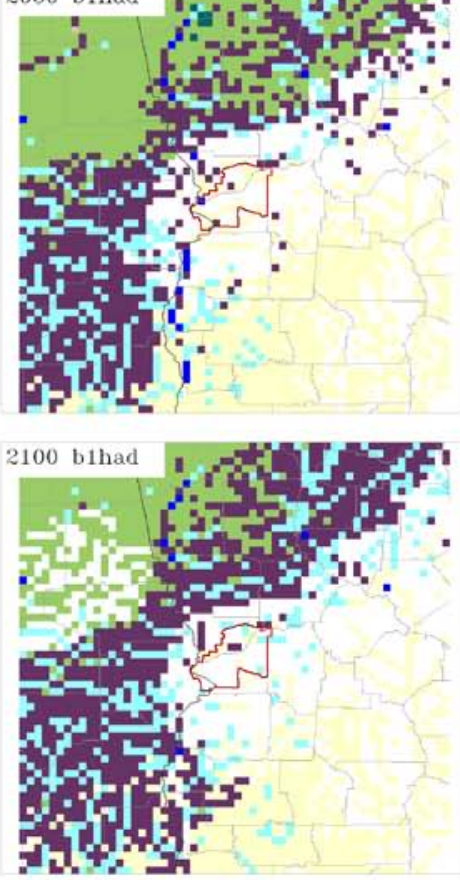
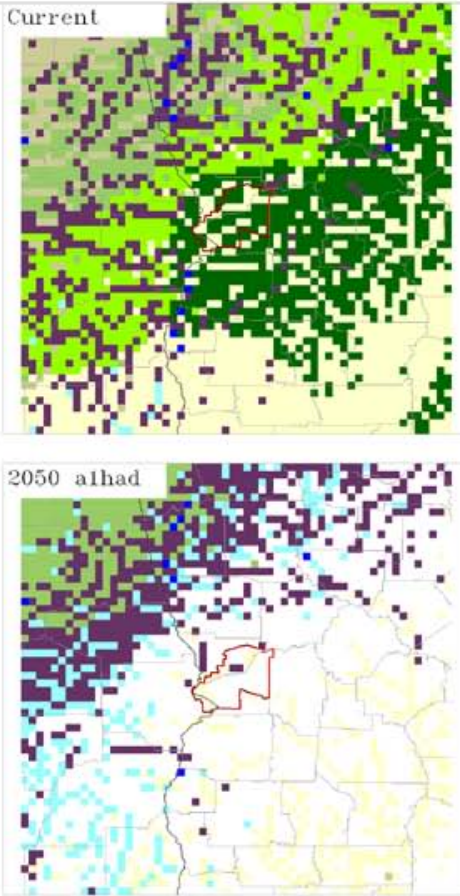

2100 alhad

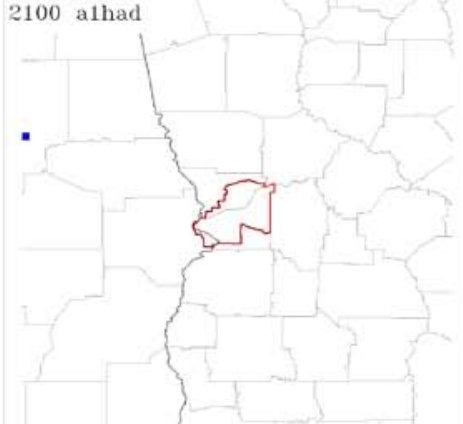


Fort Benning Military Reservation

Q0) Different from any area in the world in 2000

98) $47 \%$-Southern Acacia-Commiphora Bushlands And Thic

18\%) $31 \%$-Piedmont

499) $90 \%$-East Gulf Coastal Plain

503) $81 \%$-Mid-Atlantic Coastal Plain

707) $30 \%$-Cumberlands And Southern Ridge And Valley

715) $31 \%$-Upper East Gulf Coastal Plain

727) $82 \%$-South Atlantic Coastal Plain

729) $84 \%$-Upper West Gulf Coastal Plain

733) $97 \%$-West Gulf Coastal Plain
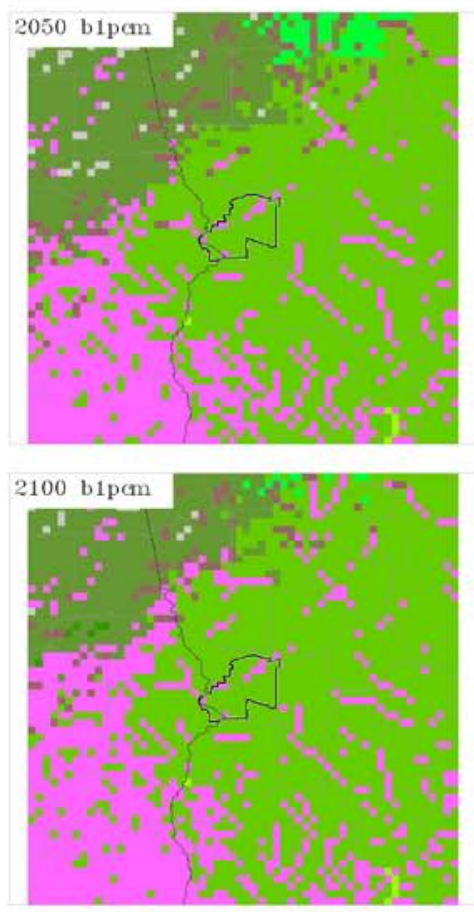
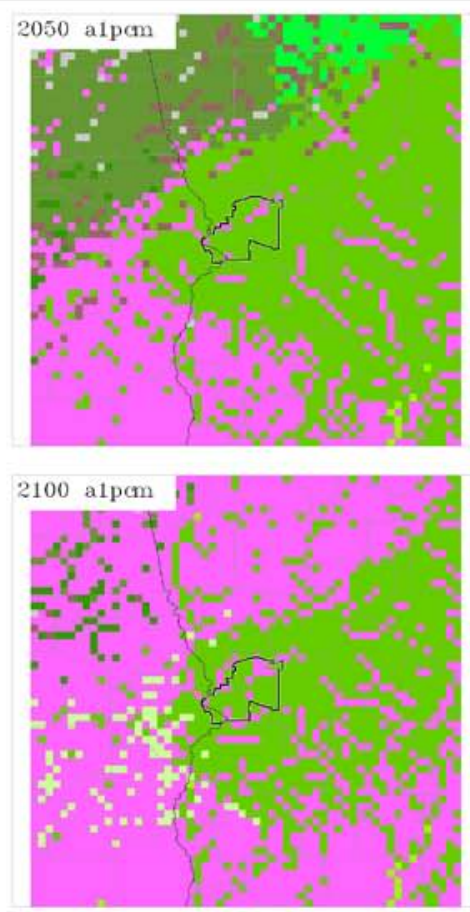
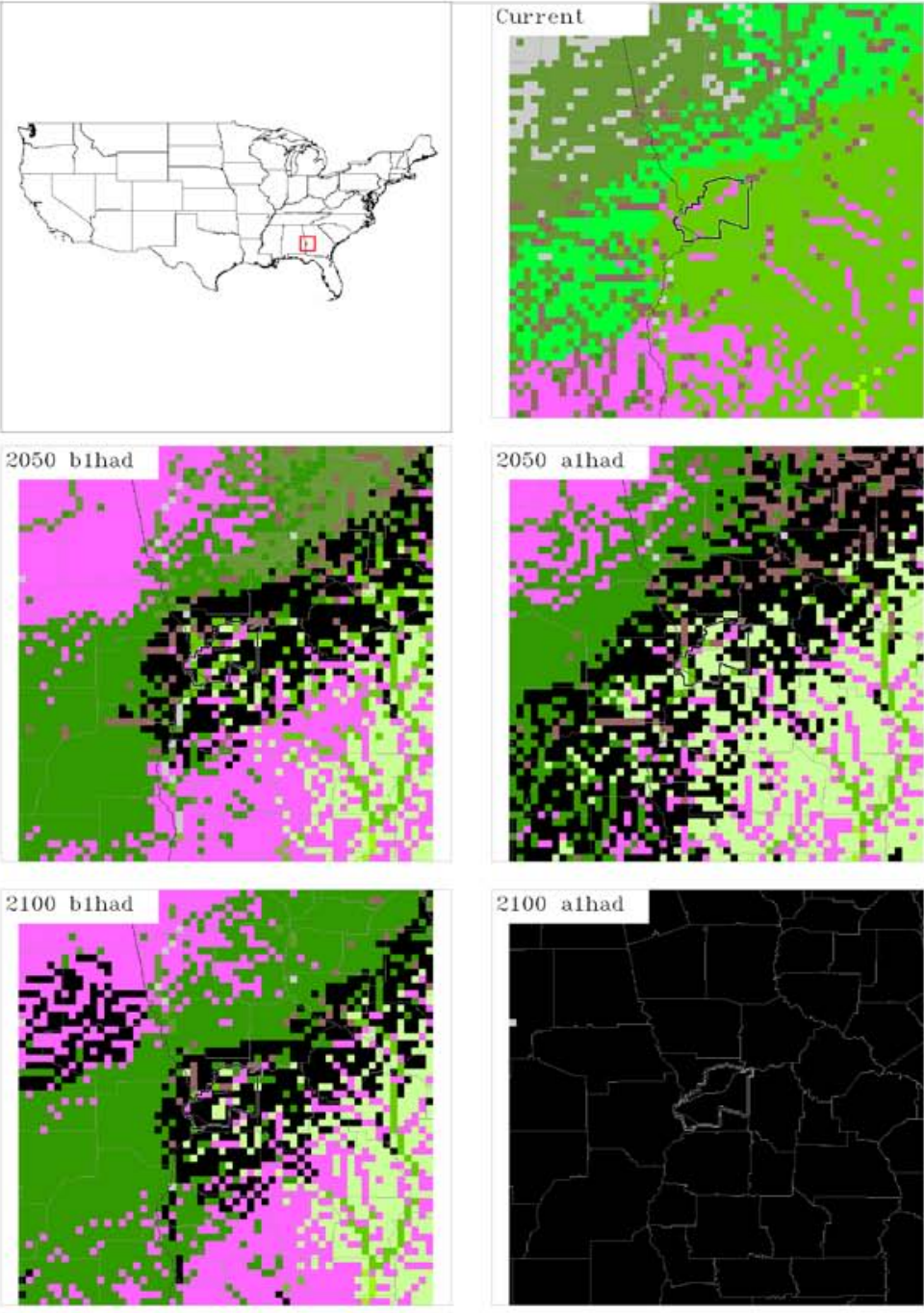

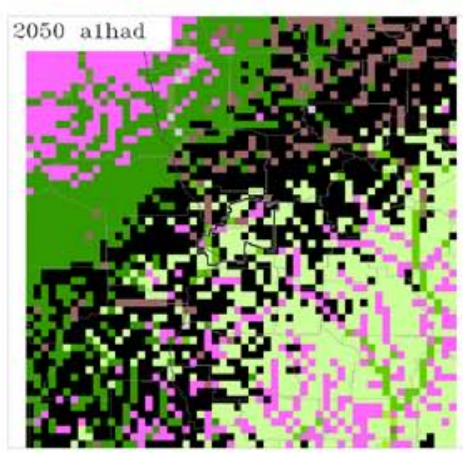

2100 alhad

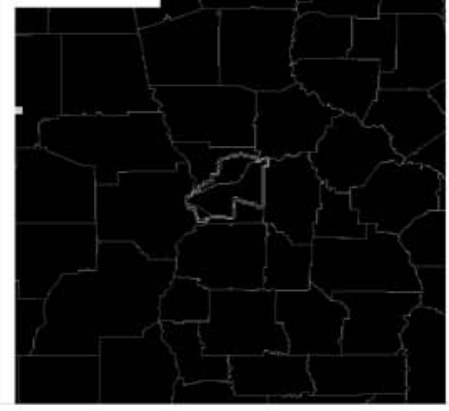


Fort Benning Military Reservation

These images show where the

forecasted physical and climate conditions most closely match

the conditions found across the region in 2000. This answers the question, "Where can I go today to find the forecasted conditions for this installation?"
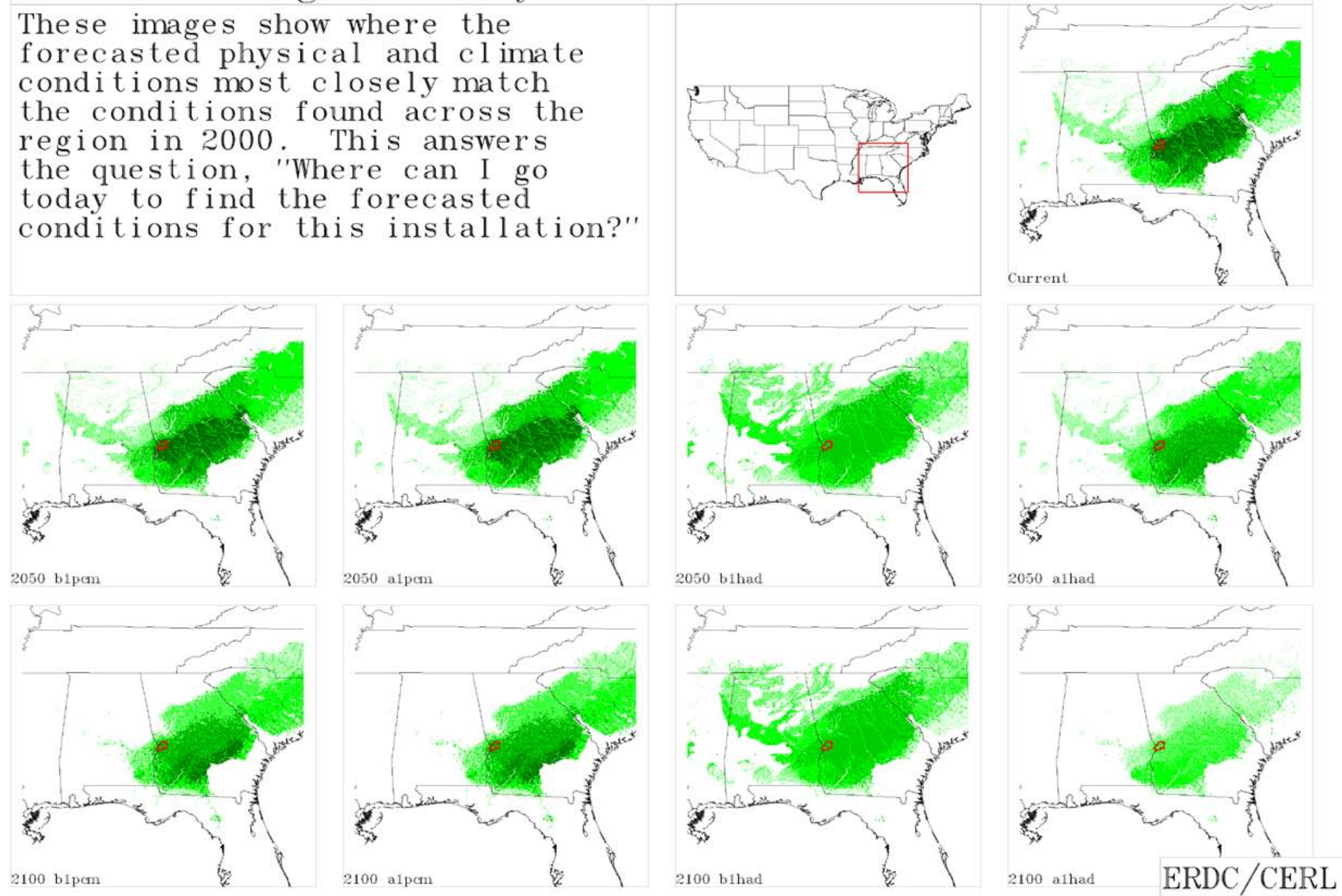

Fort Bliss 
Fort Bliss

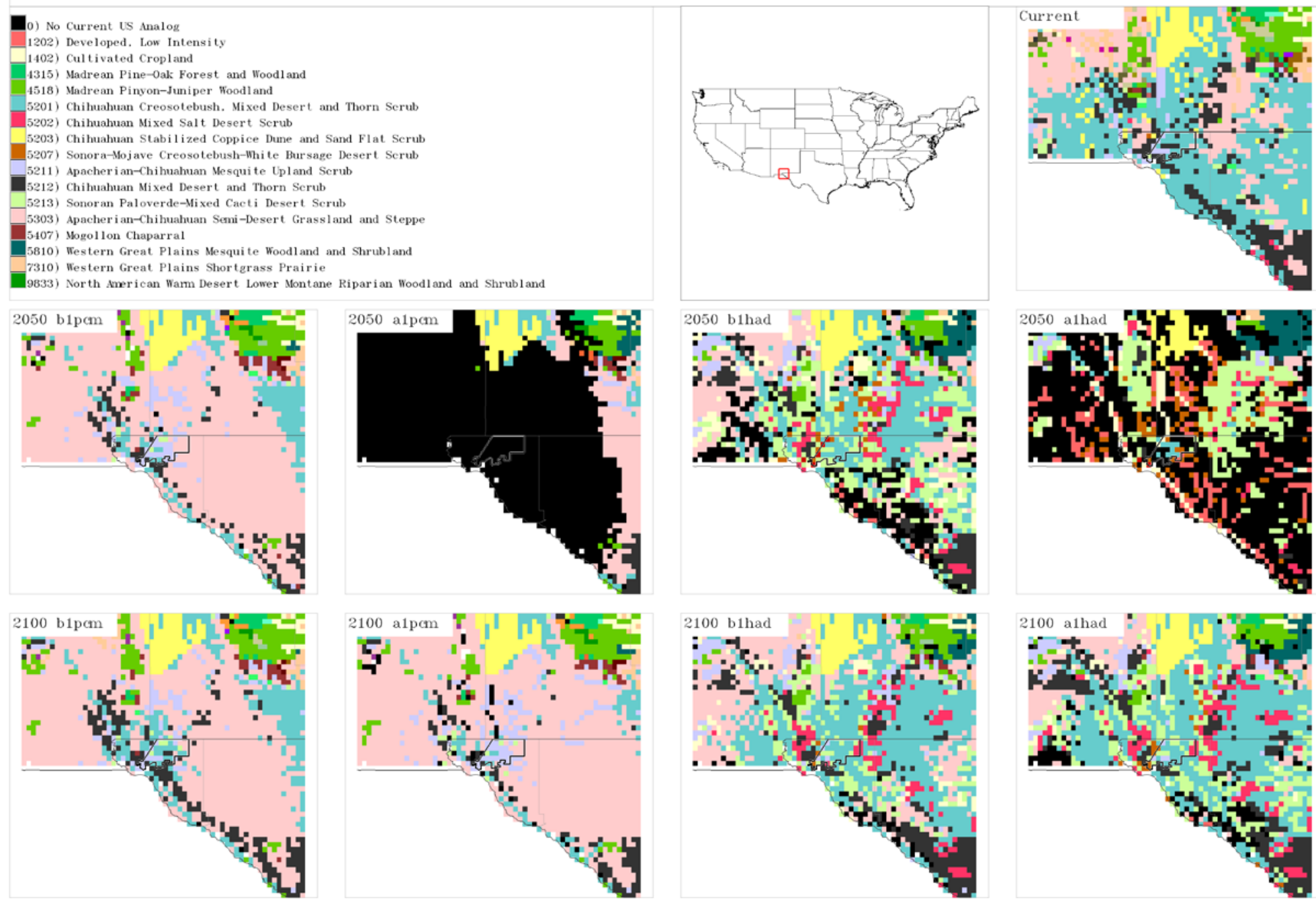


Fort Bliss

O) Different from any area in the world in 2000
93) 43 , -Northern Acacia-C(ami phora Bushl ands And Thickets

145) $96 \%$-Kalahar i Xerie Savanna

(19) 28 - Southern Shortgrass frairie

432) $56 \%$ - Espinal

134) $37 \%$ - Low Monte

-

693) 64 \% - Pegistan-North Pakistan Sandy Desert

703) 558 -Sonoran-Sinaloan Trumeition Subtropical Dry Forest

704) 49: -Sierra Madre Occidental Pine-

763) 715 ; - -Apache Highlands

765) $30 \%$-Chiluahuan Deser
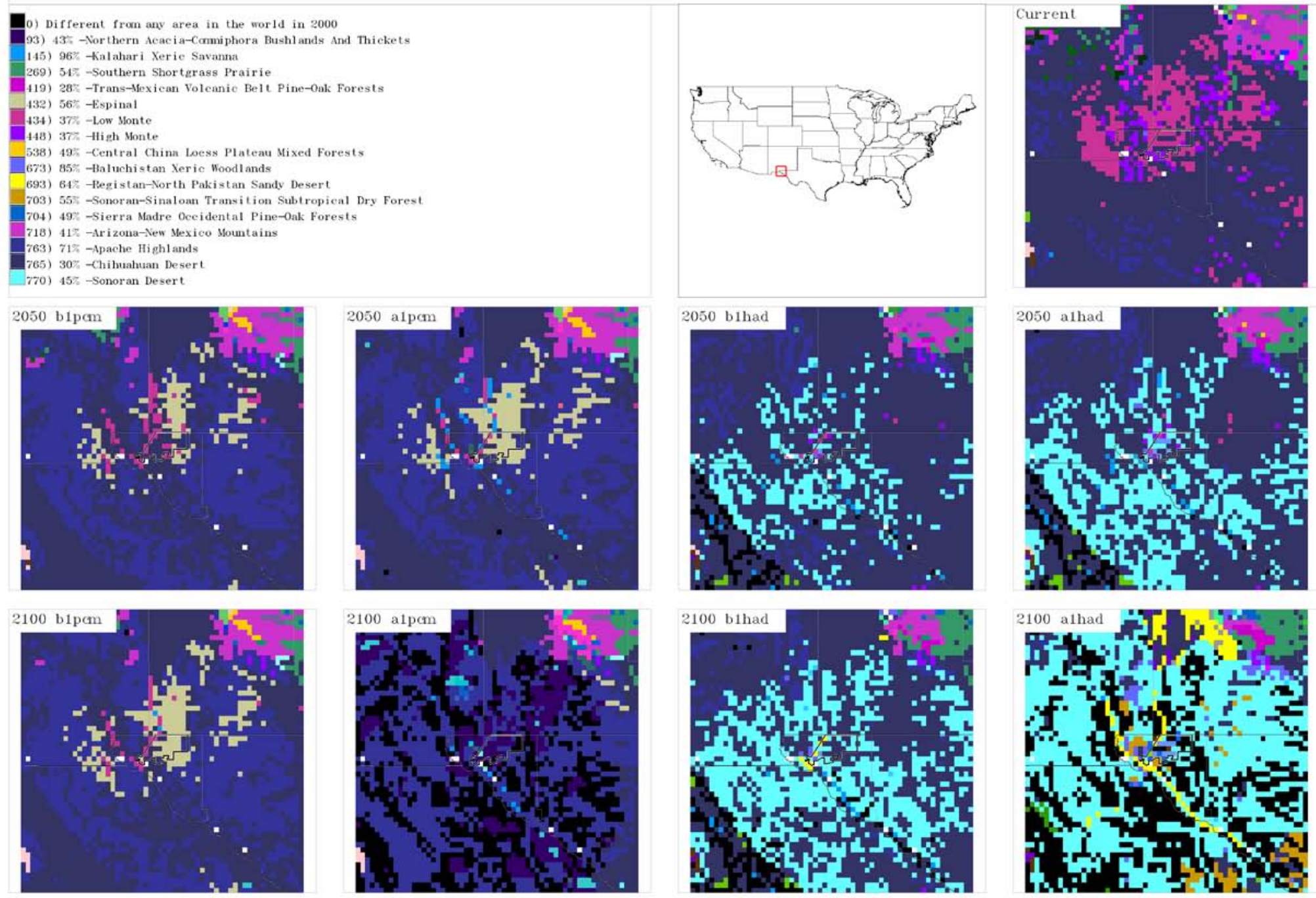


\section{Fort Bliss}

These images show where the

forecasted physical and climate conditions most closely match

the conditions found across the region in 2000. This answers the question, "Where can I go today to find the forecasted conditions for this installation?"

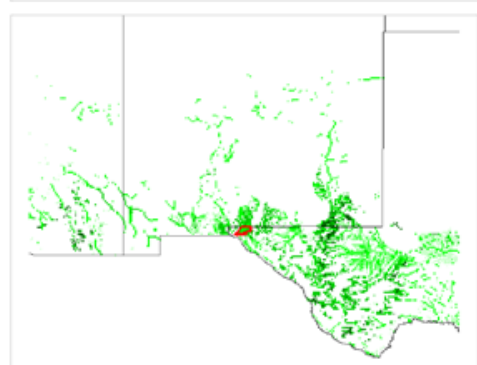

$2050 \mathrm{~b} 1 \mathrm{pcm}$

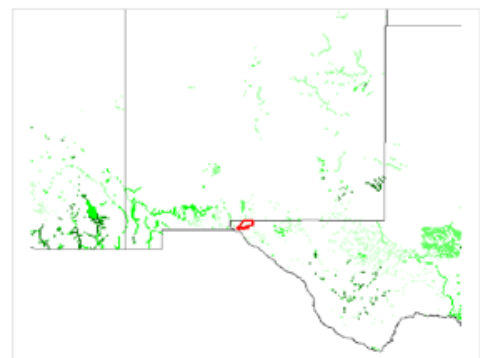

$2100 \mathrm{~b} 1 \mathrm{pcm}$

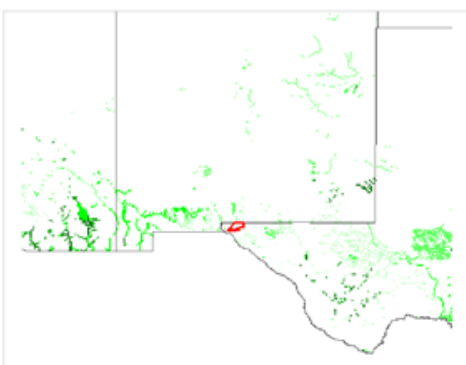

2050 a1pcm

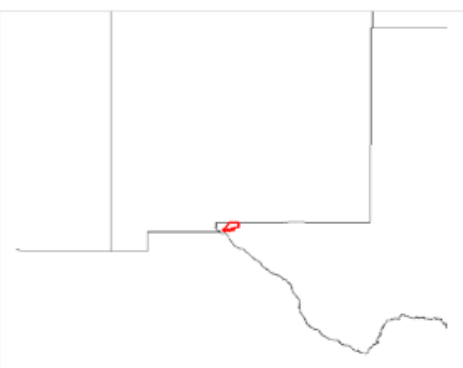

$2100 \mathrm{a} 1 \mathrm{pcm}$
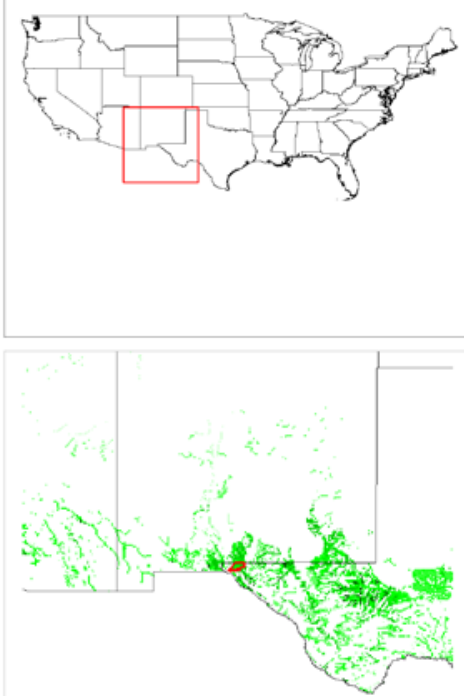

2050 b1had

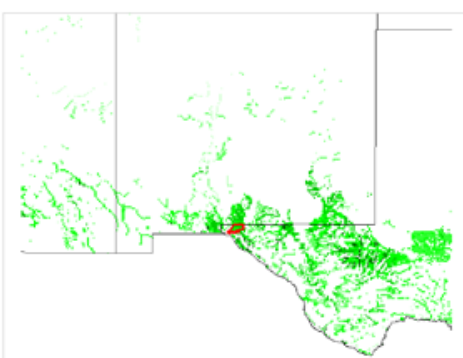

2100 b1had

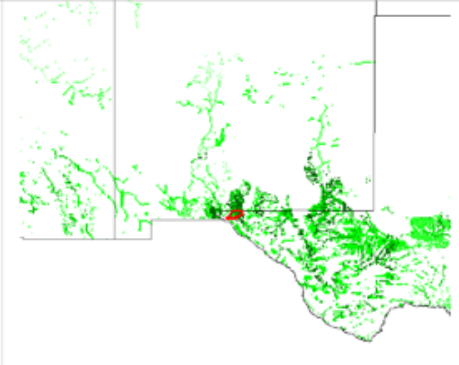

Current

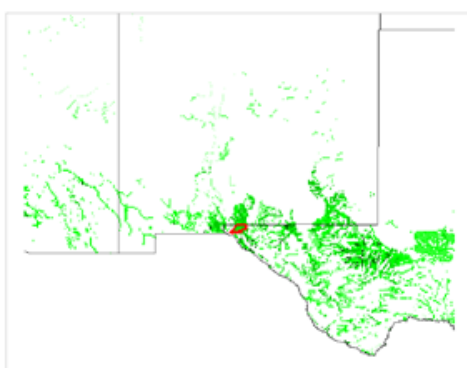

2050 a1had

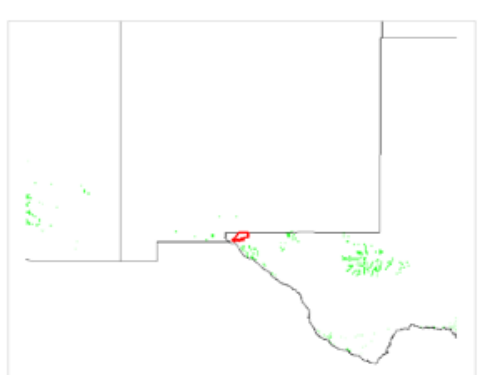

2100 alhad ERDC/CERL

Fort Bragg Military Reservation 
Fort Bragg Military Reservation

0) No Current US Analog

1402) Cultivated Cropland

1403) Pasture/Hay

4115) Ozark-Ouachita Dry-Mesic Oak Forest

4302) Southern Piedmont Dry Oak-(Pine) Forest - Hardwood Mo

4328) Ozark-Ouachita Shortleaf Pine-Oak Forest and Woodland

4508) East Gulf Coastal Plain Interior Upland Longleaf Pine

8202) Evergreen Plantations or Managed Pine (can include de

9220) Gulf and Atlantic Coastal Plain Tidal Marsh Systems

9804) East Gulf Coastal Plain Large River Floodplain Fores

9903) East Gulf Coastal Plain Near-Coast Pine Flatwoods -
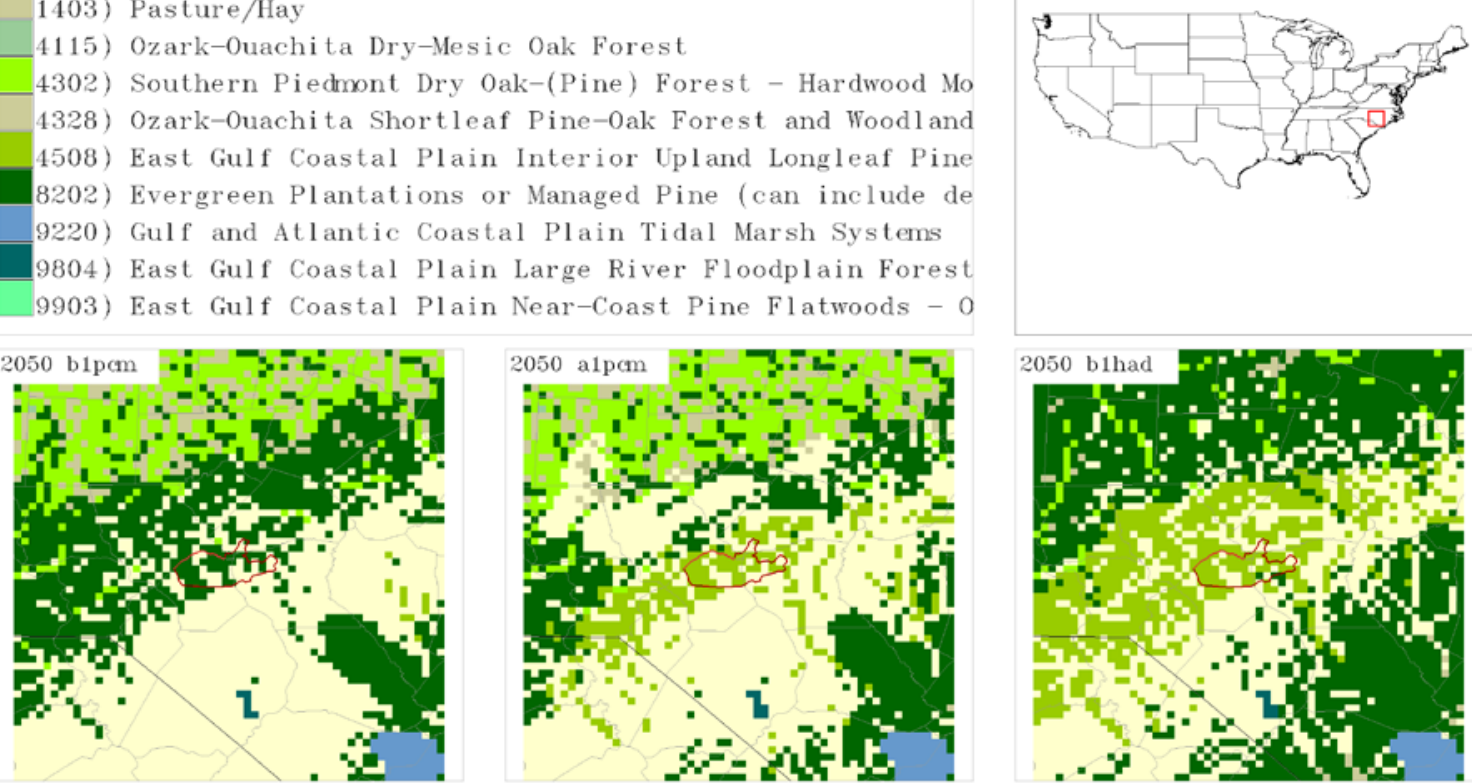

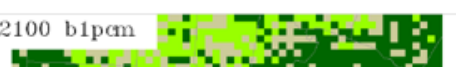
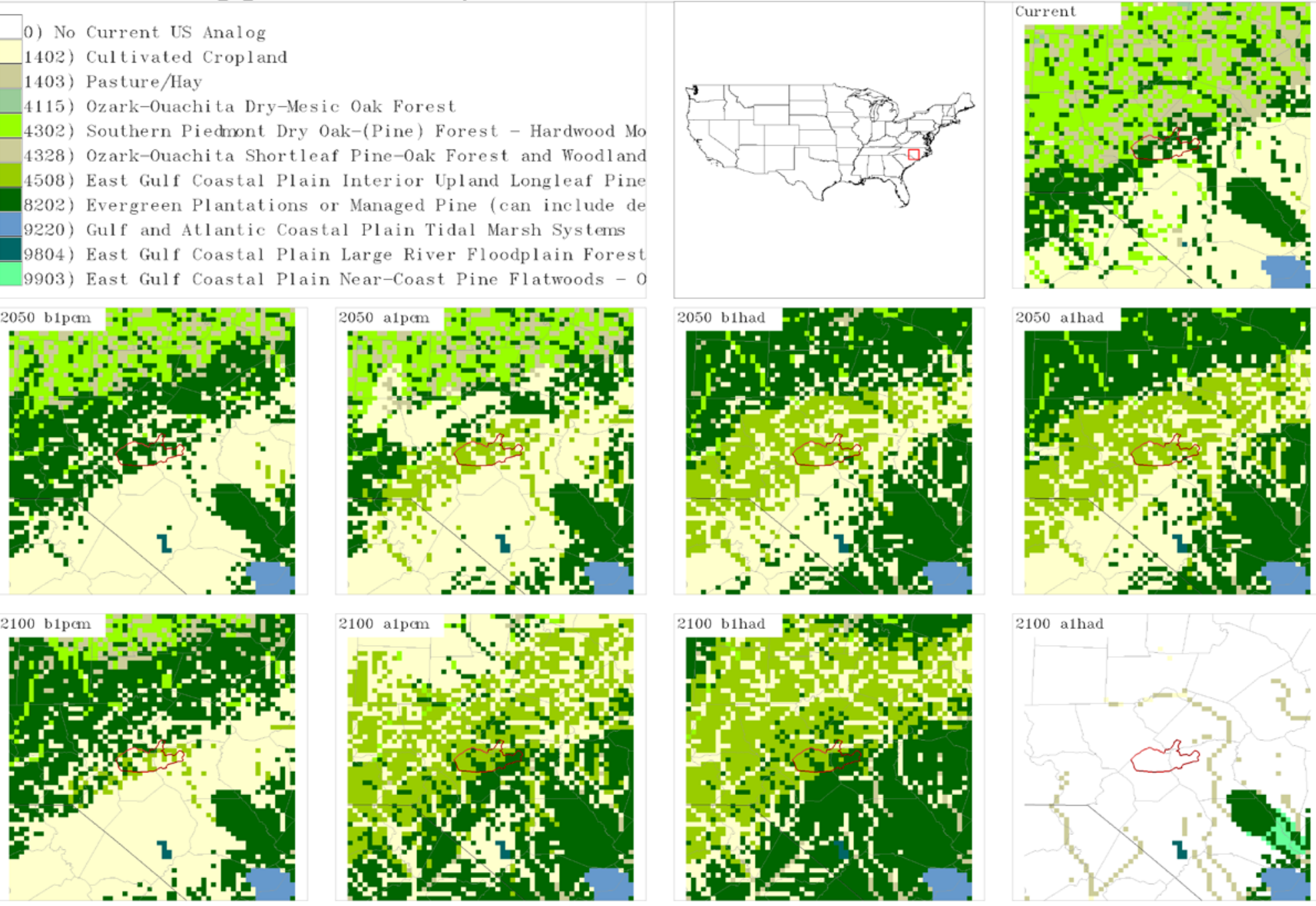

2100 a1had

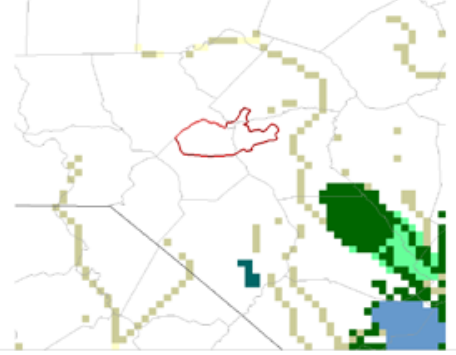




\section{Fort Bragg Military Reservation}

0) Different from any area in the world in 2000

185) $76 \%$-Ouachita Mountains

187) $31 \%$-Piedmont

293) $71 \%$-Alto Paran Atlantic Forests

499) $90 \%$-East Gulf Coastal Plain

500) $33 \%-$ Florida Peninsula

503) $81 \%$-Mid-Atlantic Coastal Plain

712) $61 \%$-Mississippi River Alluvial Plain

727) $82 \%$-South Atlantic Coastal Plain

746) $100 \%$-Gulf Coast Prairies And Marshes
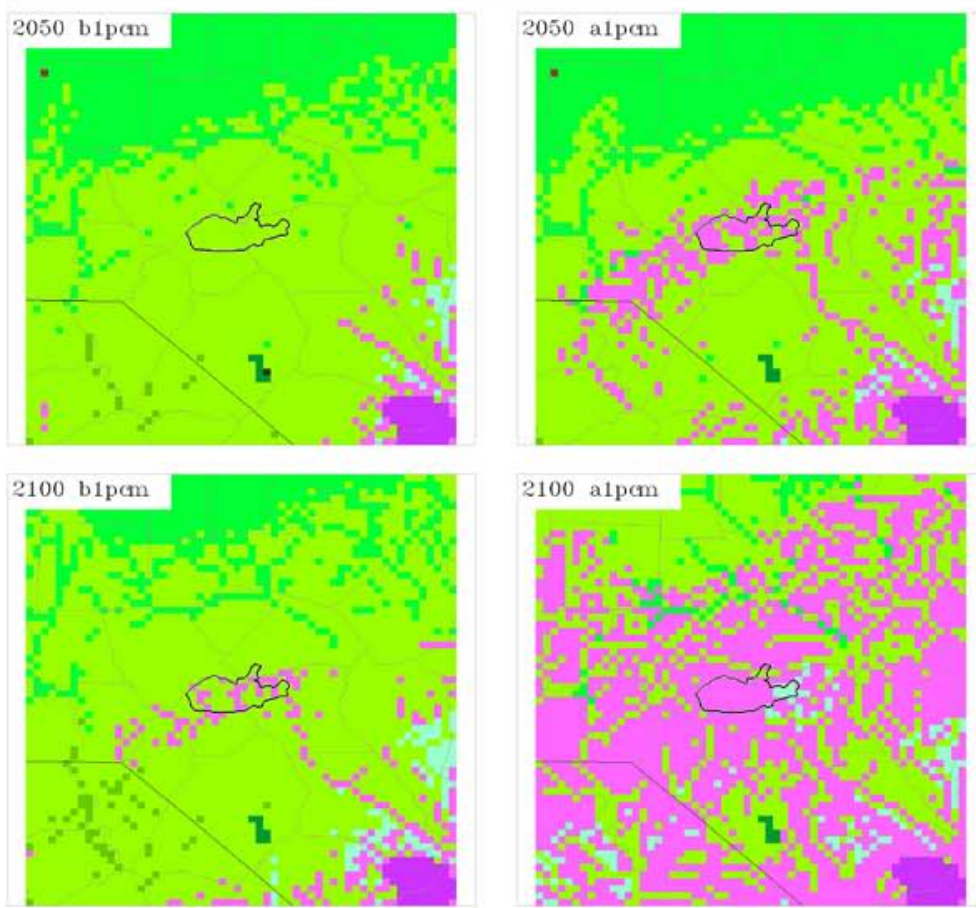
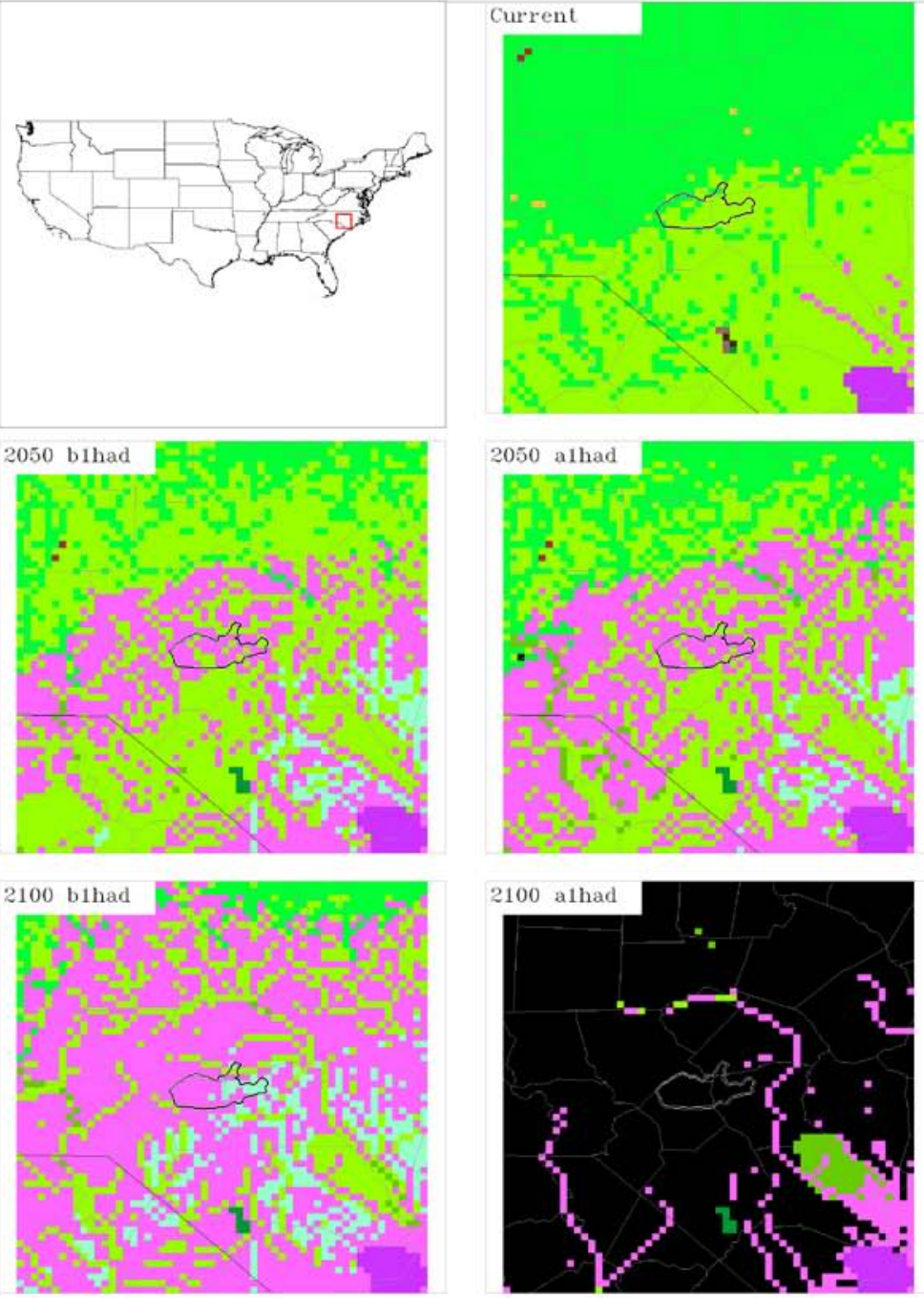
Fort Bragg Military Reservation

These images show where the

forecasted physical and cl imate conditions most closely match

the conditions found across the region in 2000. This answers the question, "Where can I go today to $f$ ind the forecasted conditions for this installation?"
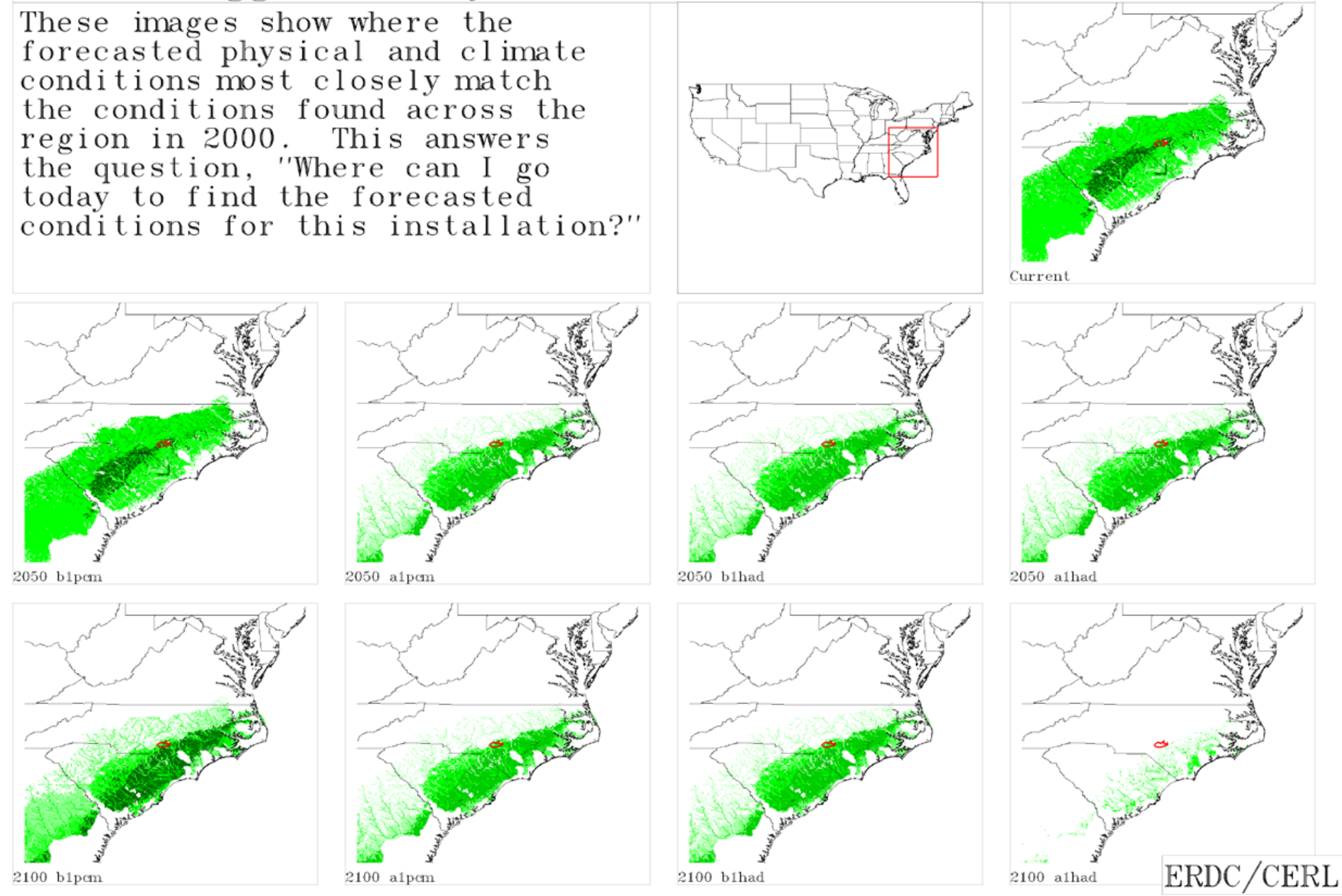

Fort Campbell 
Fort Campbel l
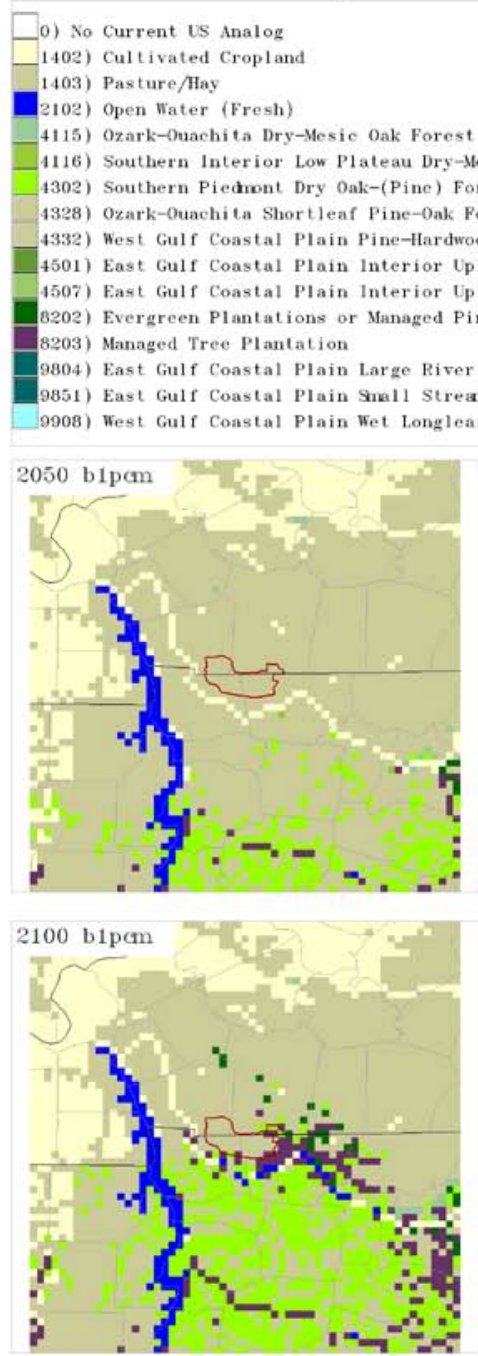
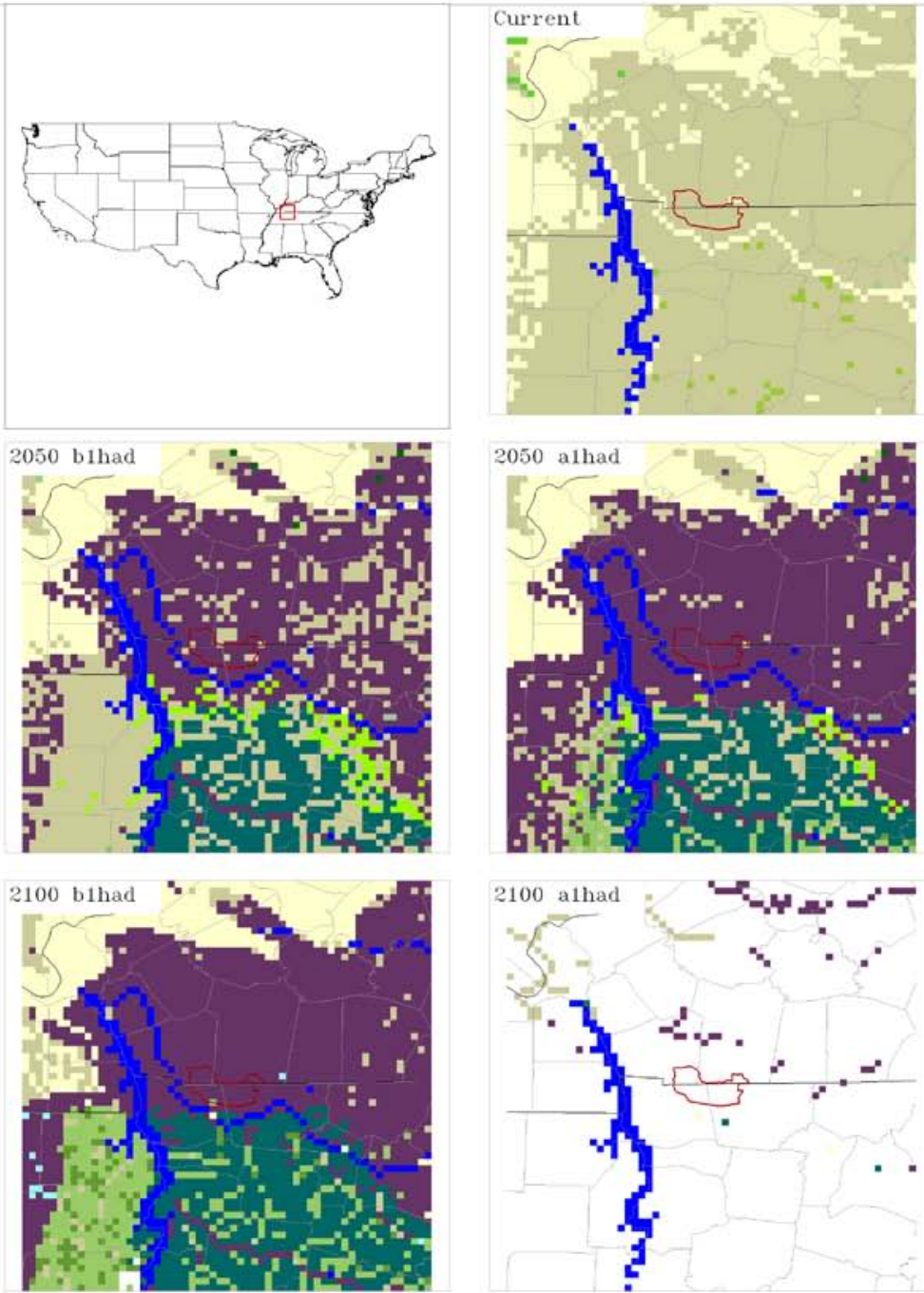
Fort Campbell
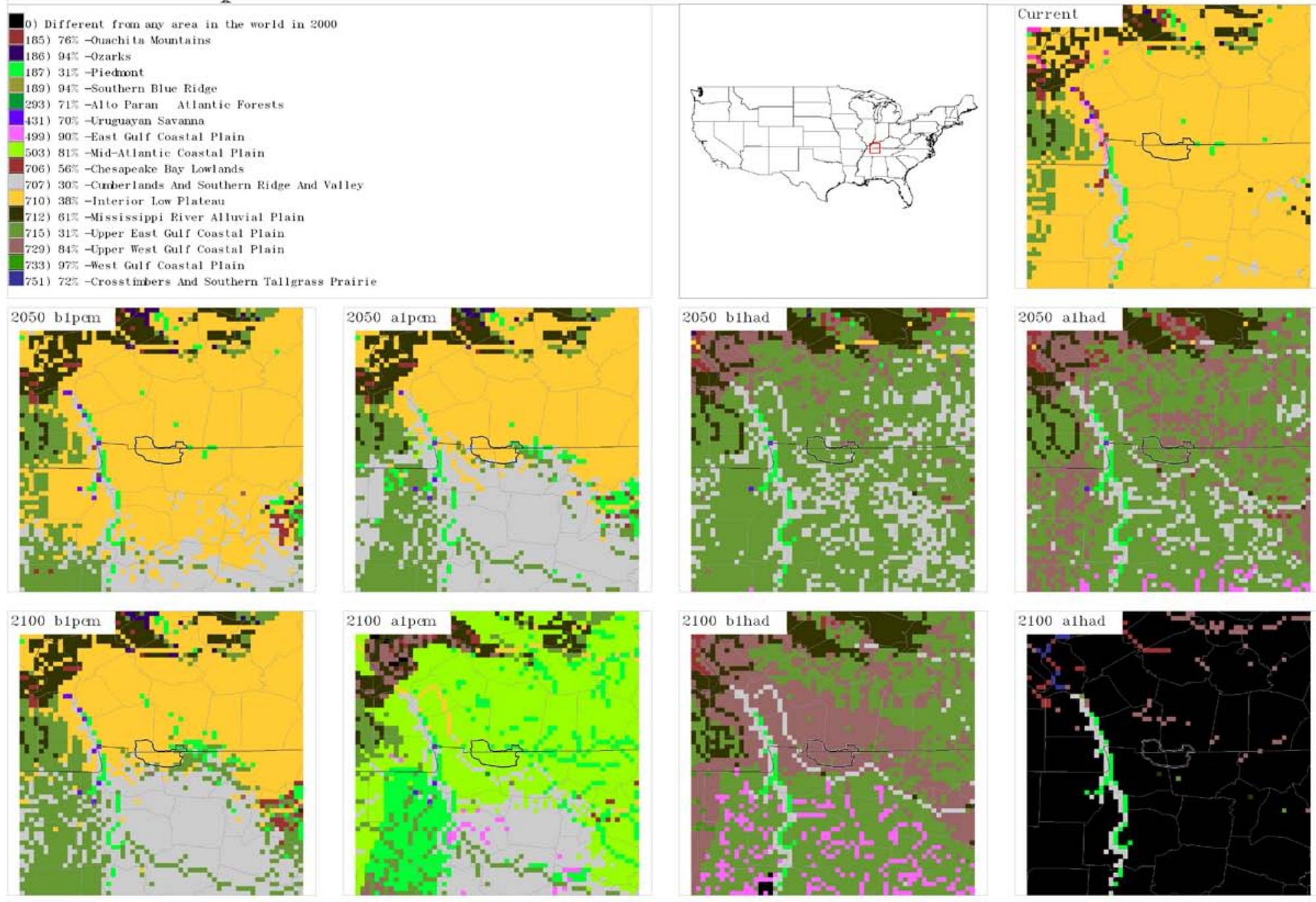
Fort Campbell

These images show where the forecasted physical and climate conditions most closely match the conditions found across the region in 2000. This answers the question, "Where can I go today to find the forecasted conditions for this installation?"
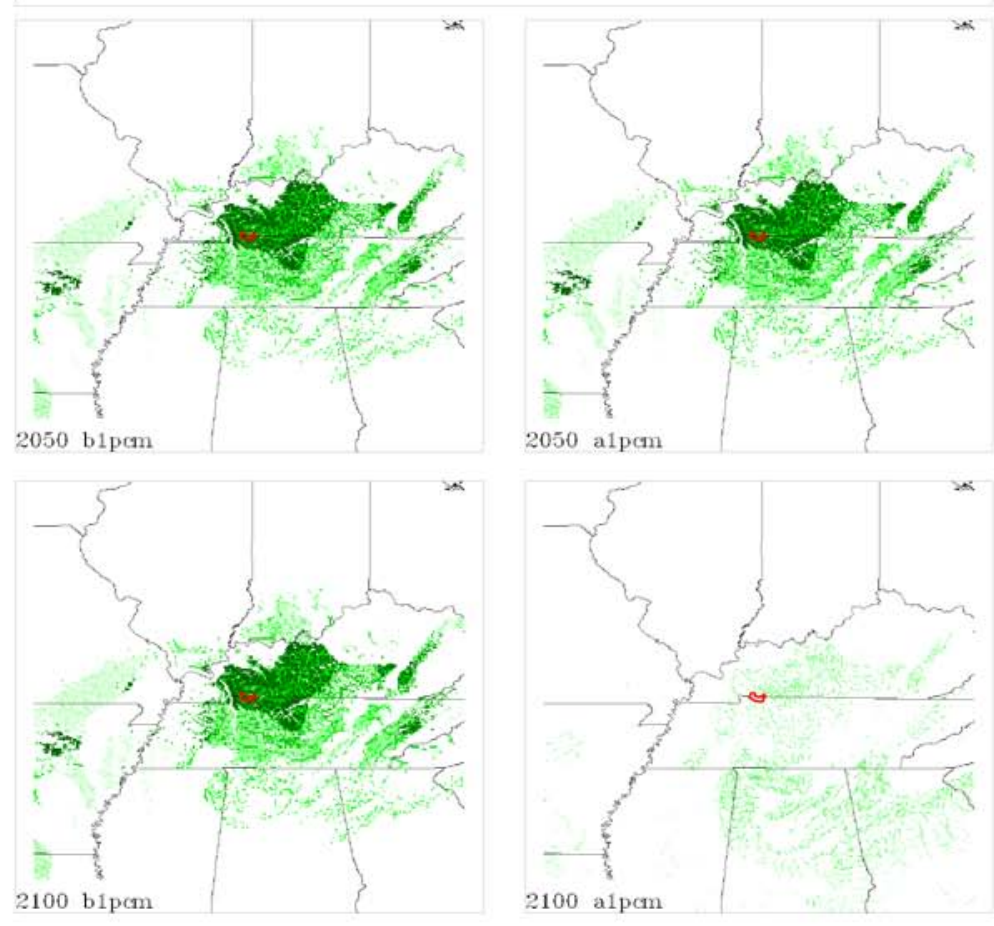
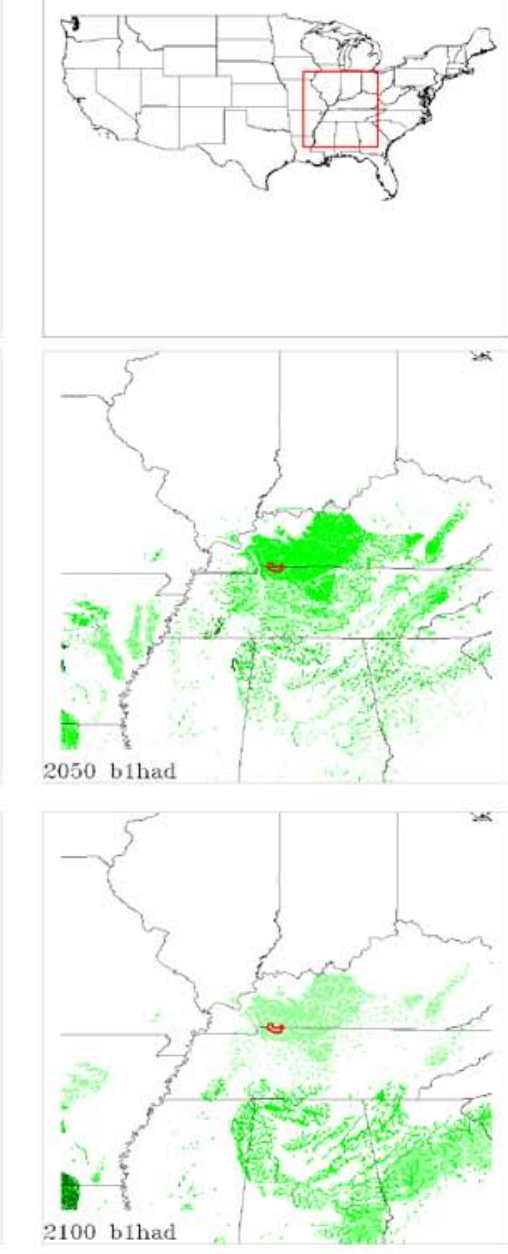

Fort Carson Military Reservation
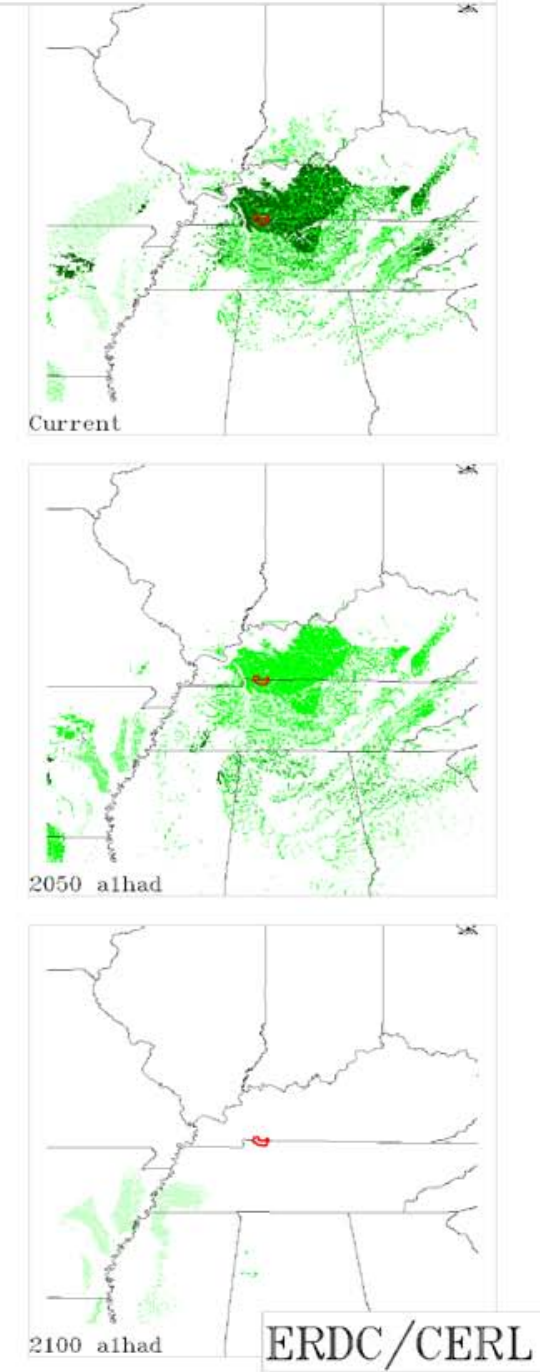
Fort Carson Military Reservation

0) No Current is Analog
1402) Cultivated Cropland

- 1402) Cultivated Cropland

- 1512) Colorado Plateau Pinvon-Jumiper Woodland

4518) Madrean Pinyon-Jumiper Woodland

4530) Southern Rocky Mountain Ponderosa Pine Woodl and

531) Bocky Mountain Subalpine Dry-lesic Spruce-fir Forest and Woodlan 5201) Chituahuan Creosotebush. Mixed Desert and Thorn Scrub

(2) Chinuahuan Mixed Desert and Thorn Seruib

and and Steppe

5308) Inter-Mountain Rasins Montane Sagebrush Steppe
5706) Inter-Mountain Basins Big Sagebrush Shrubland

7206) Southern Rocky Mountain Montane-Subalpine Grassland

7306) Nor thestern Great Plains Mixedgrass Prair

7310) Western Great Plains Shorterass Prair
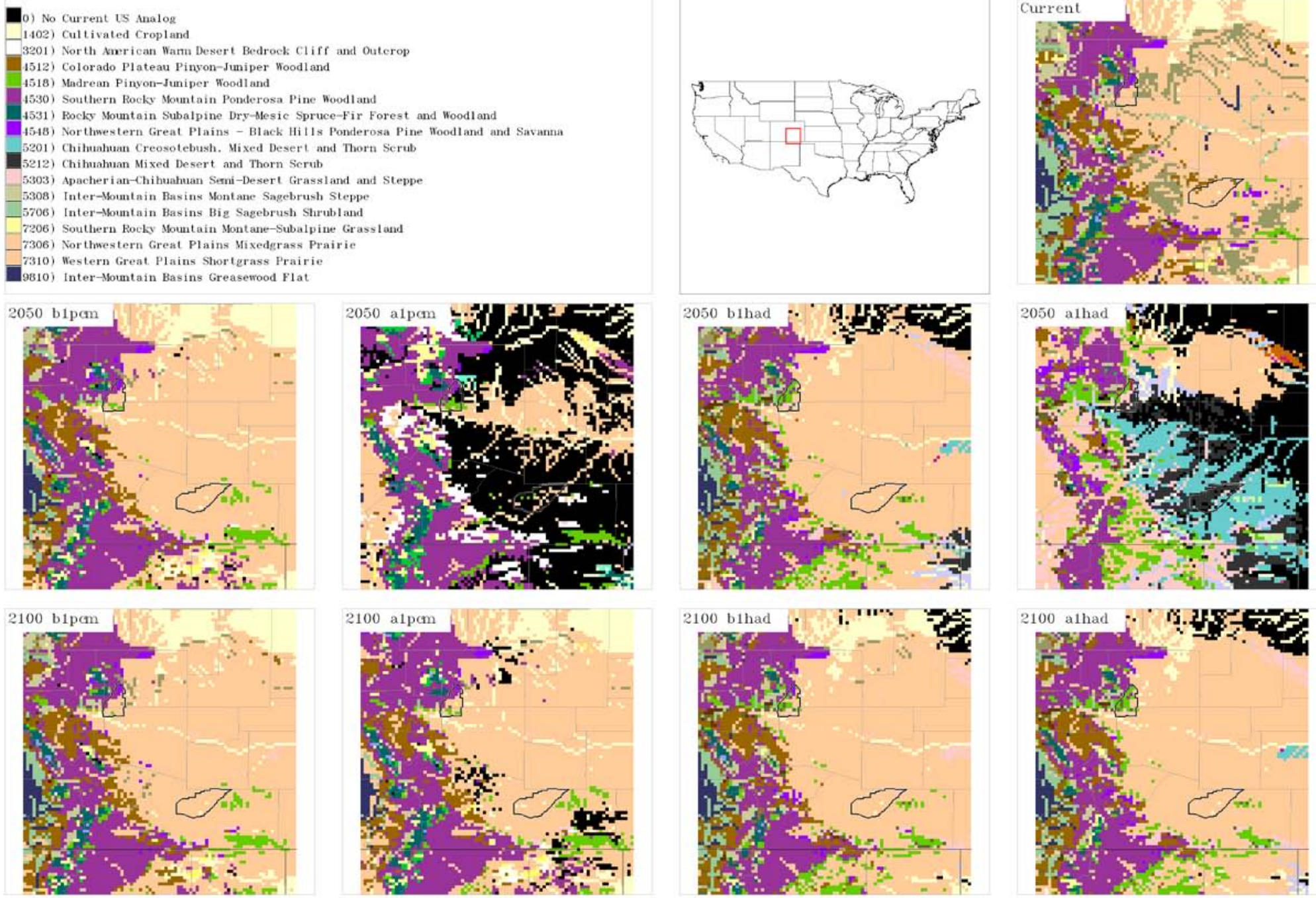
Fort Carson Military Reservation
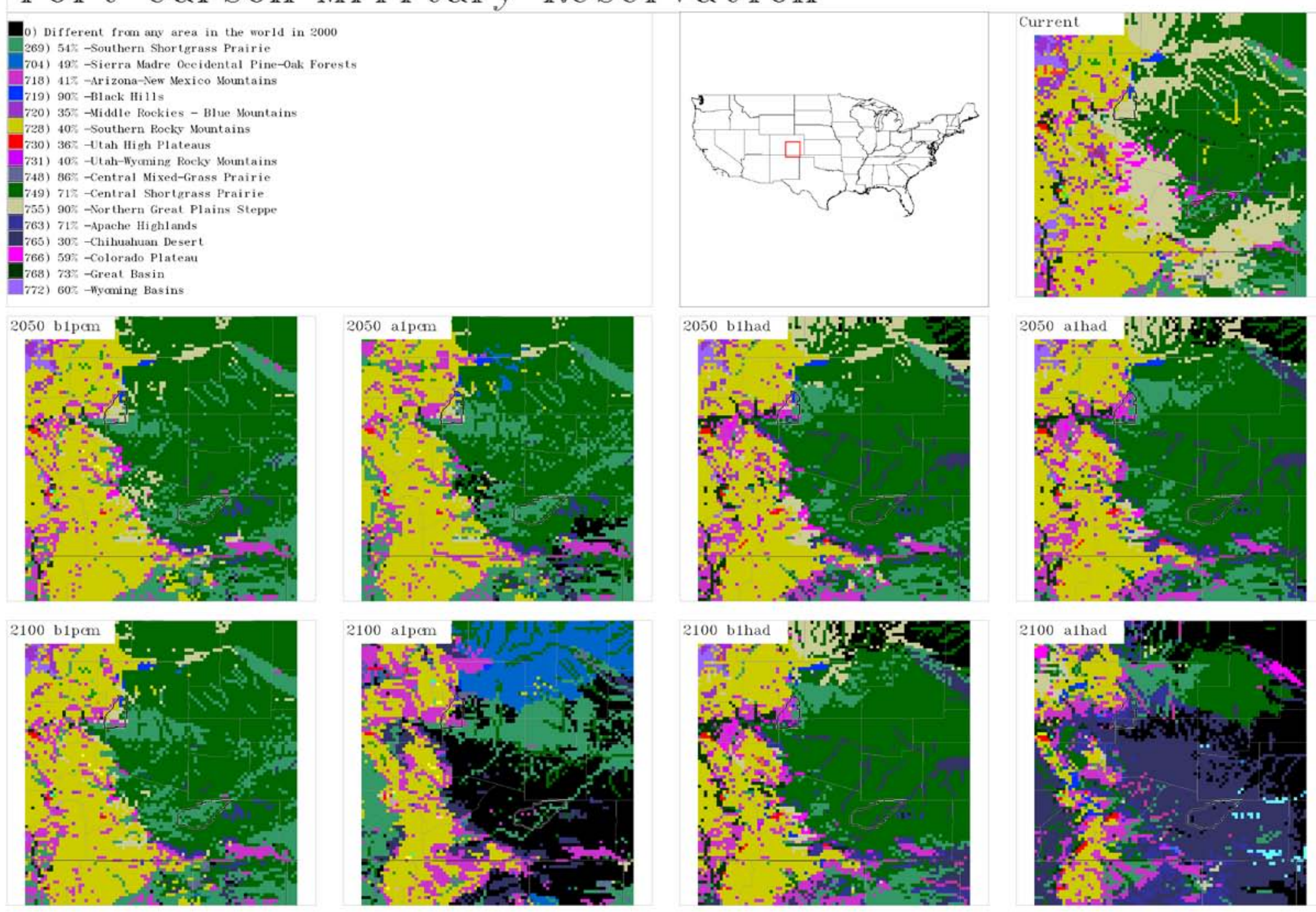
Fort Carson Military Reservation

These images show where the

forecasted physical and climate conditions most closely match

the conditions found across the region in 2000. This answers the question, "Where can I go today to $\mathrm{f}$ ind the forecasted conditions for this installation?"
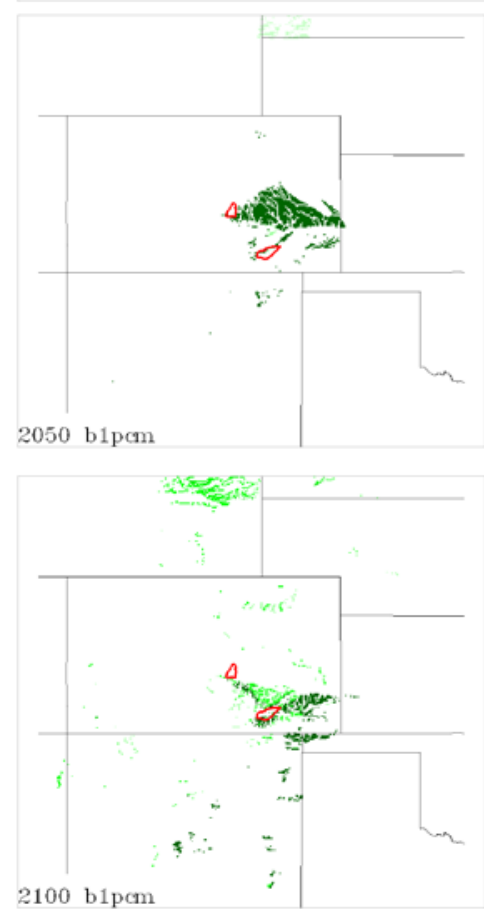
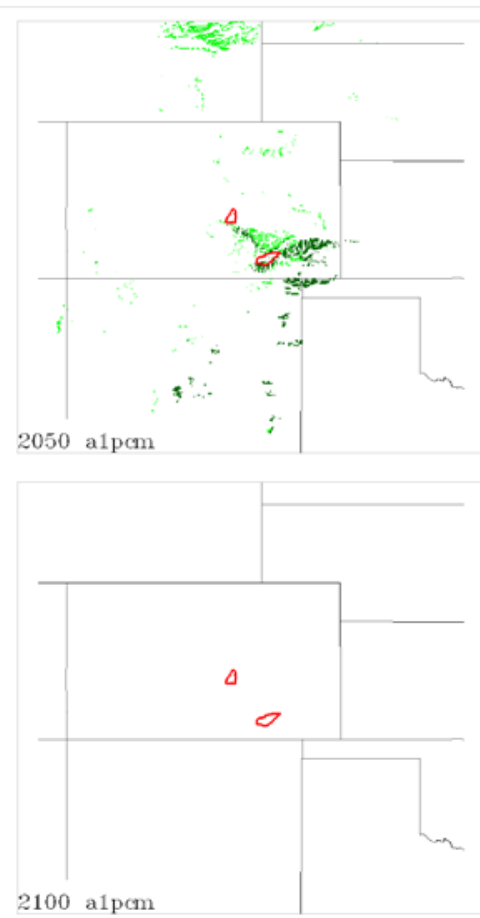
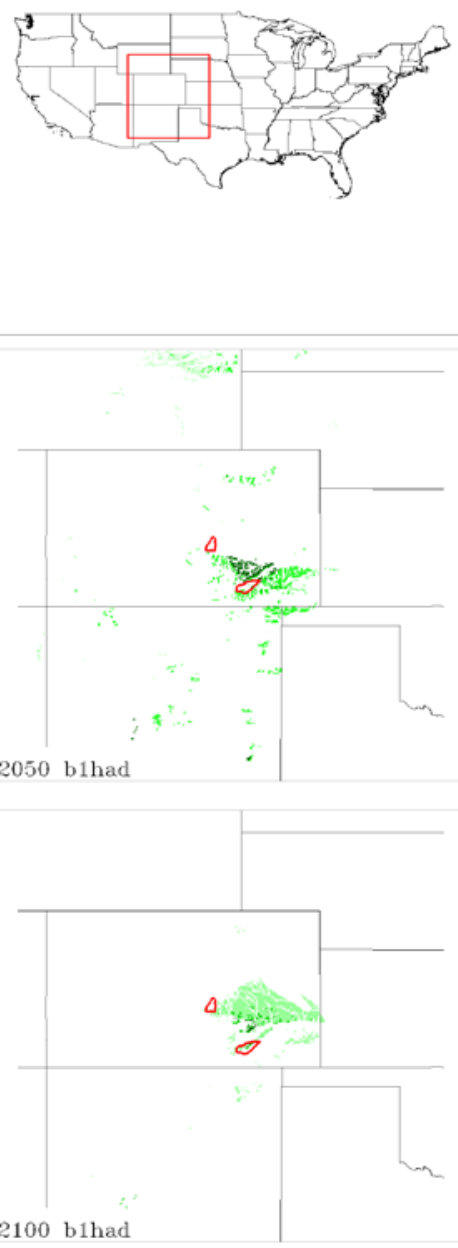

Fort Drum
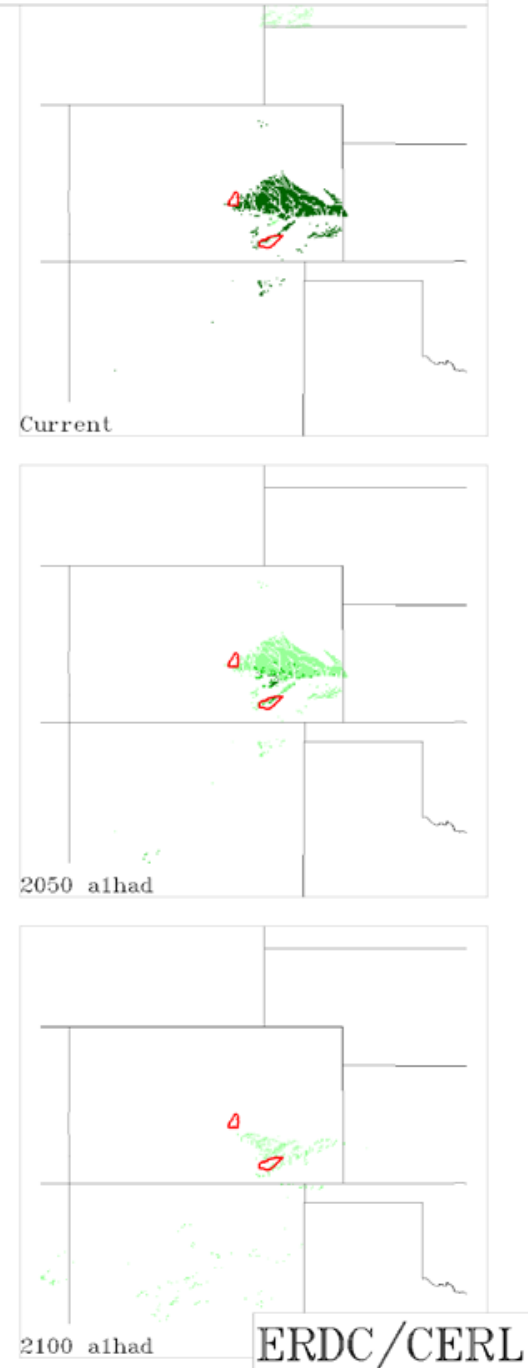
Fort Drum

4313) Northern Atlantic Coastal Plain Dry Hardwood Fores

1330) Central Appalachian Oak and Pine Fores

1393) ceadian Low-Elevation Som

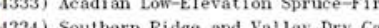

4.01) Southern and Central Appalachian Cove Forest

4551) Acadian-Appatachian Montane Spruce-Fir Forest

8201) Deciduous Plantations
B501) Disturbed. Non-specifie

8504) Raderal Wetlant

9212) Central Interior and Appalachian Sway System

9214) Laurentian-Acadian Swaip Systeris

-9308) Laurentian-Acadian Alkal ine Coni fer-Hardwood Swamp
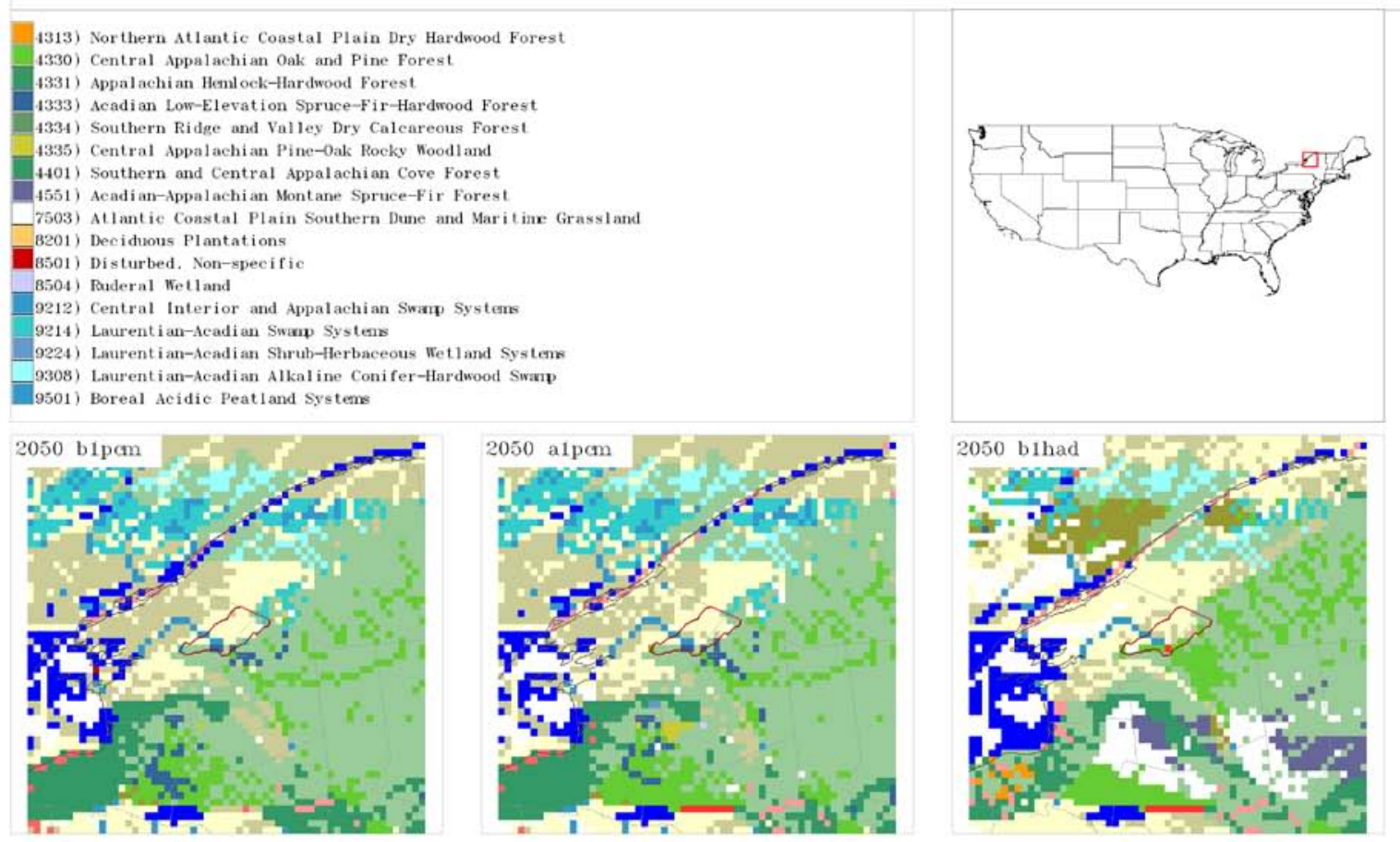

$2100 \mathrm{~b} 1 \mathrm{pcm}$

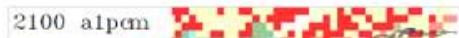
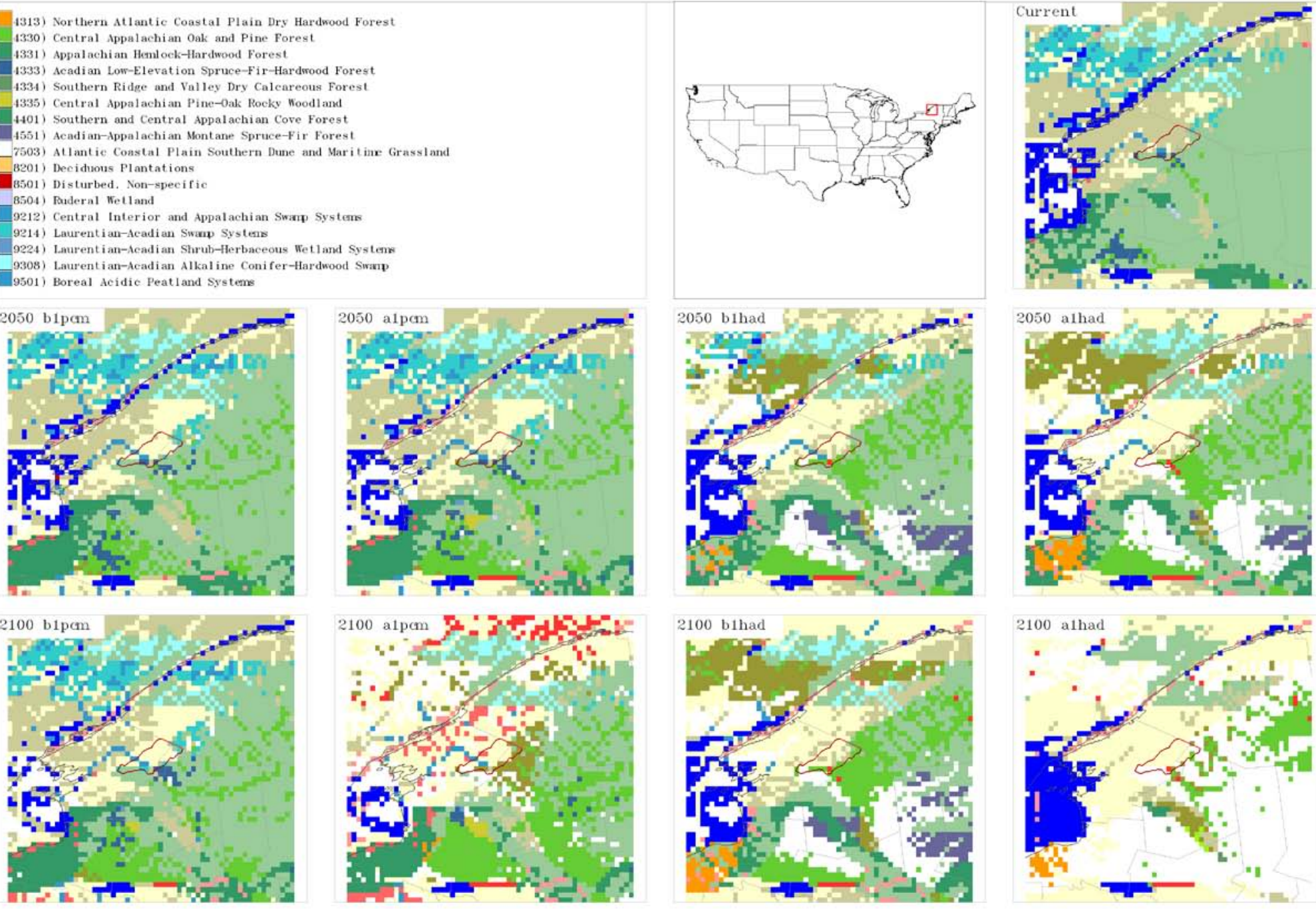
Fort Drum

Do) Different from any area in the world in 2000

182) $47 \%$-North Atlantic Coast
184) $53 \%$ - - Torthern Appalachian / Acadian

558) $100 \%$ - Pamnonian Mixed Forests

559) $67 \%$ Po Basin Mixed Forests
571) 39 - Hestern European Broadleaf Forest

705) 56\% -Central Appalachion Fores

(06) 56: -Chesapeake Bay Lowlant

708) $78 \%$ - Great Lake

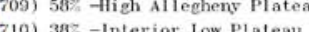

711) 73 - -Lower New Fngland / Northern Pietent

712) $61 \%$-Mississippi River Alluvial Plain

713) $100 \%$-St. Larrence - Champlain Valley

15) 41 \% - Thper East Gulf Coastal Plain Alegheny Plateau

729) $84 \%$ - Cpper West Gulf Coastal Plai
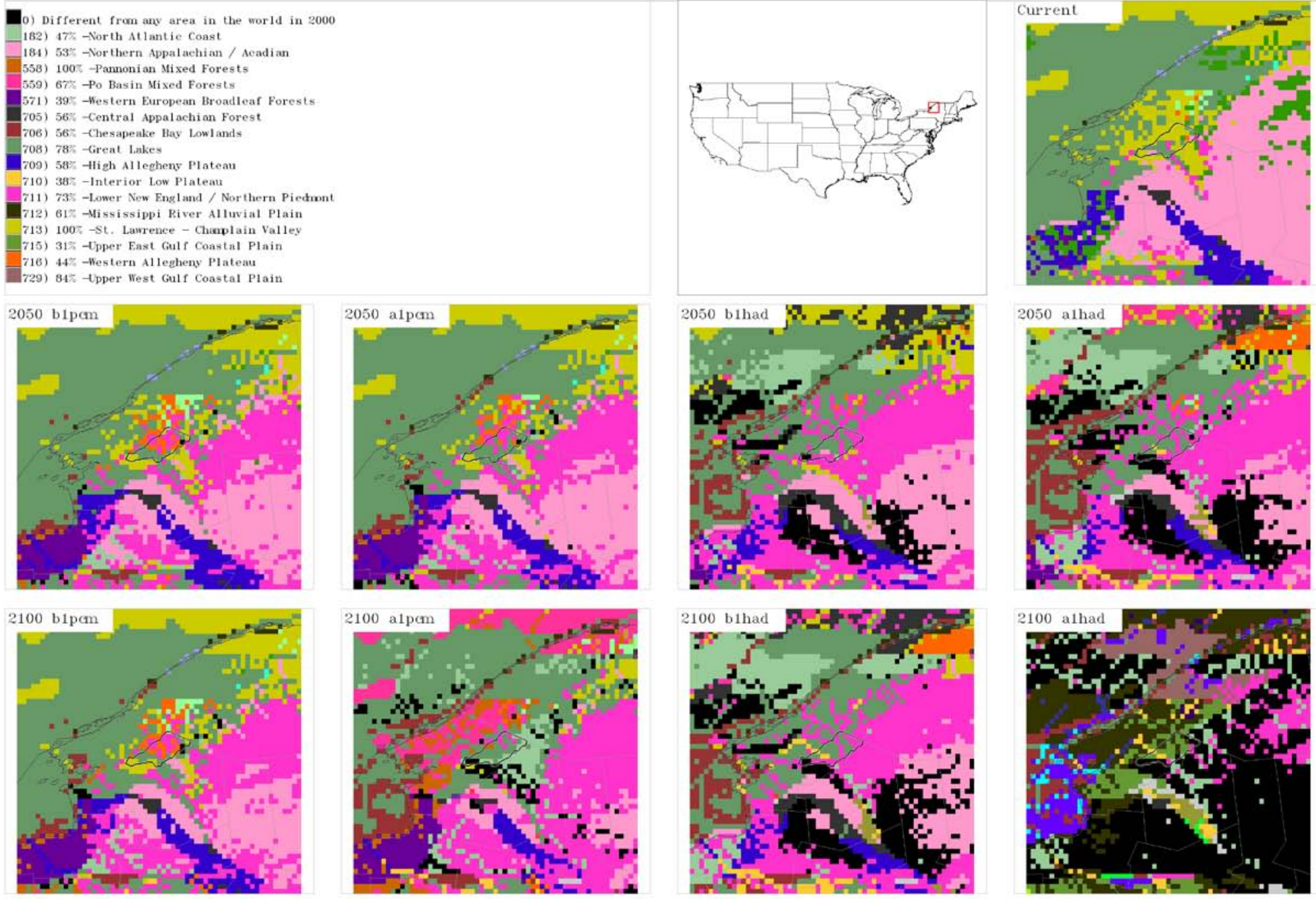


\section{Fort Drum}

These images show where the forecasted physical and climate conditions most closely match the conditions found across the region in 2000. This answers the question, "Where can I go today to find the forecasted conditions for this installation?"
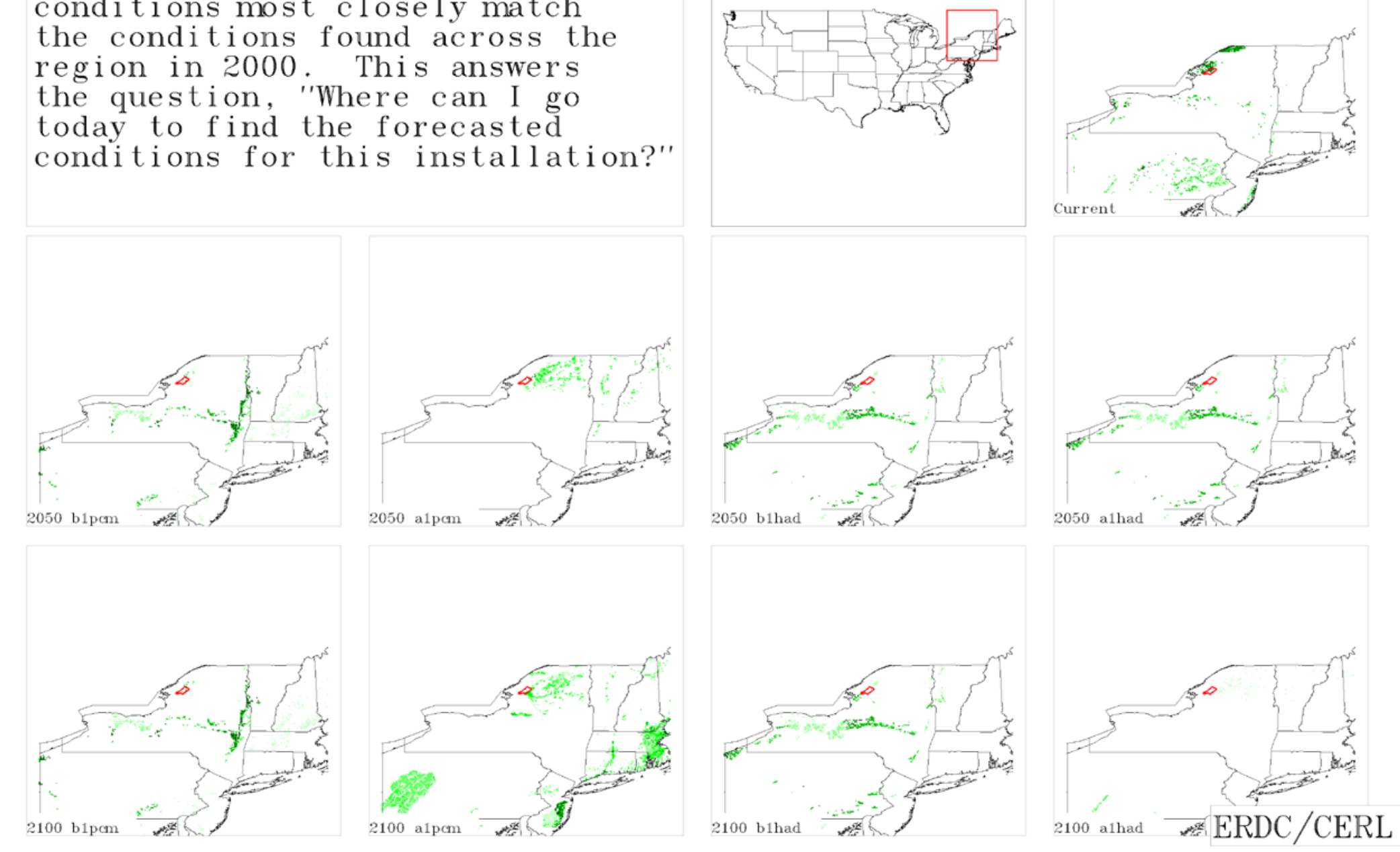

Fort Gordon 
Fort Gordon

-0) No Current US Analog

1201) Developed, Open Space

1403) Pasture/Hay

2102) Open Water (Fresh)

4302) Southern Piedmont Dry Oak-(Pine) Forest - Hardwood Modifier

4332) West Gulf Coastal Plain Pine-Hardwood Forest

1507) East Gulf Coastal Plain Interior Upland Longleaf Pine Woodland - Lob

4508) East Gulf Coastal Plain Interior Upland Longleaf Pine Woodland - Ope

202) Evergreen Plantations or Managed Pine ( $\mathrm{can}$ include dense successiona 203) Managed Tree Plantation

9842) At

9908) West Gulf Constal Plain Wet Longlear Pi
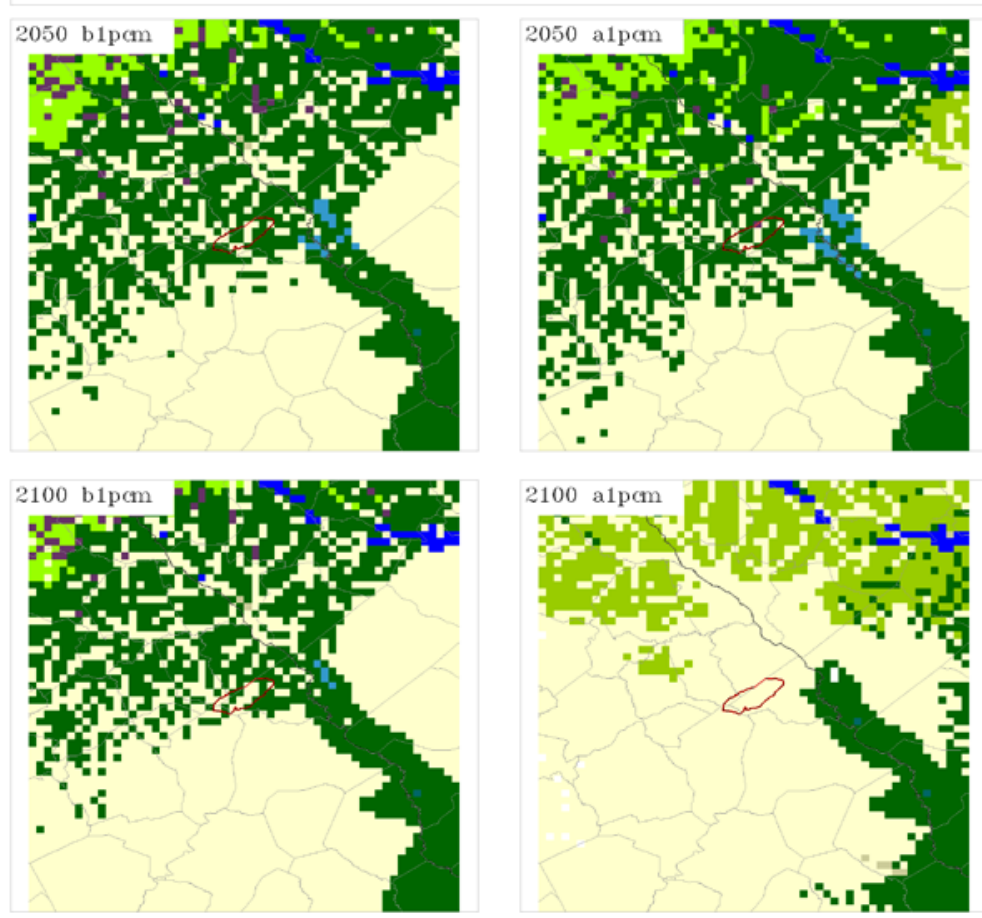
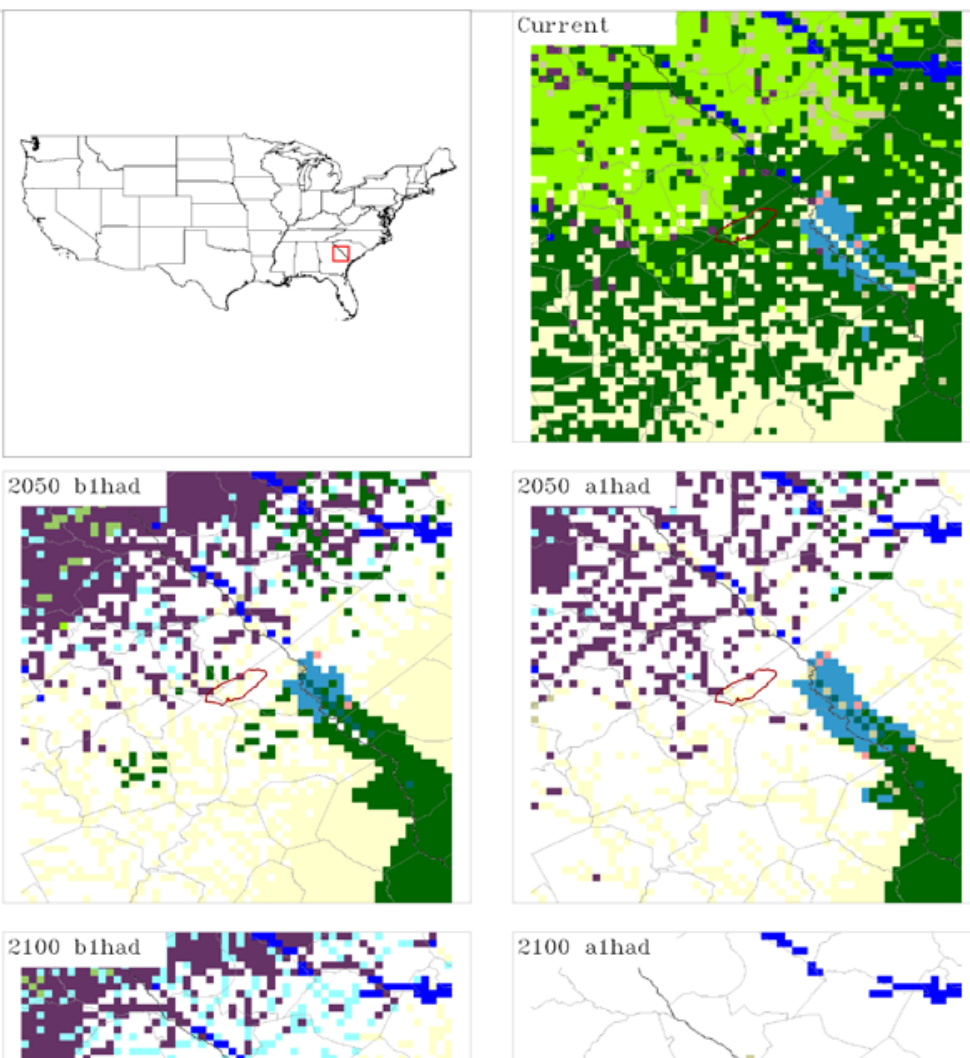

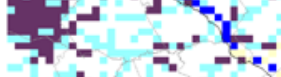

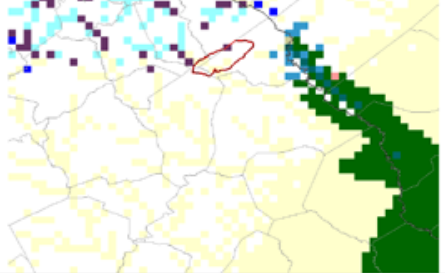


Fort Gordon

D) Different from any area in the world in 2000

-Southern Acacia-Cami phora Busta

185) 76 -Ouachita Mountain

187) $31 \%$-Piedmont

T) Alto Paran Atlantic Porest.

499) $90 \times-$ East Gut cosana

500) $335-$ Flor id Peninsula

503) B1\% -Mid-Atlantic Coastal Plain

707) 30 -Cumberlands And Southern Ridge And Yolley

712) 615 -Mississippi River Alluvial Plain

715) $31 \%$-tpper East Gulf Coastal Plain

127) 82 -South Atlantic Coastal Plain

733) 975 - West Gulf Coastal Plain

-Crosetinders the South
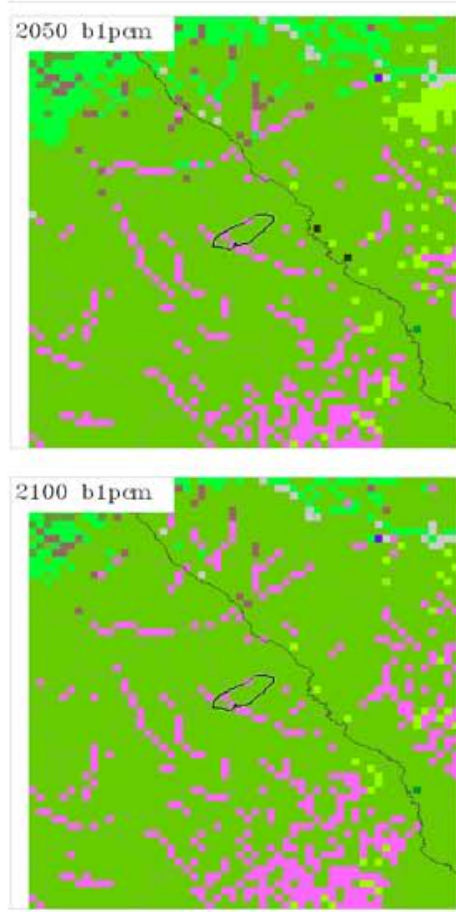
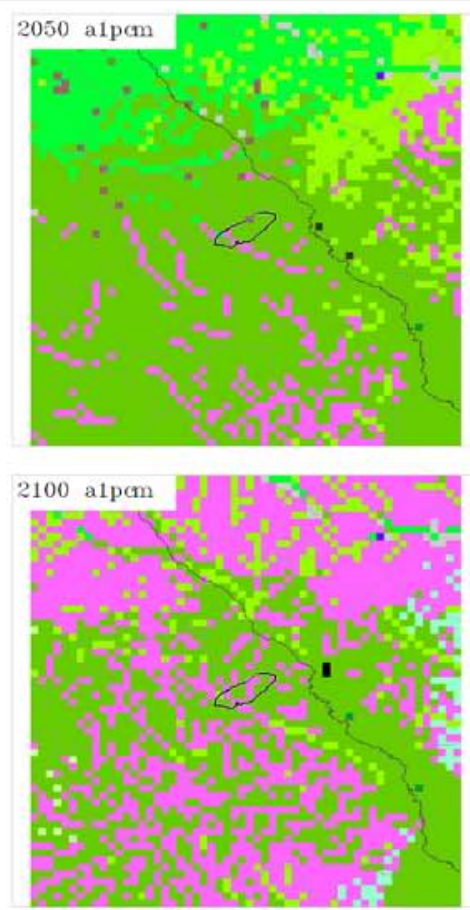
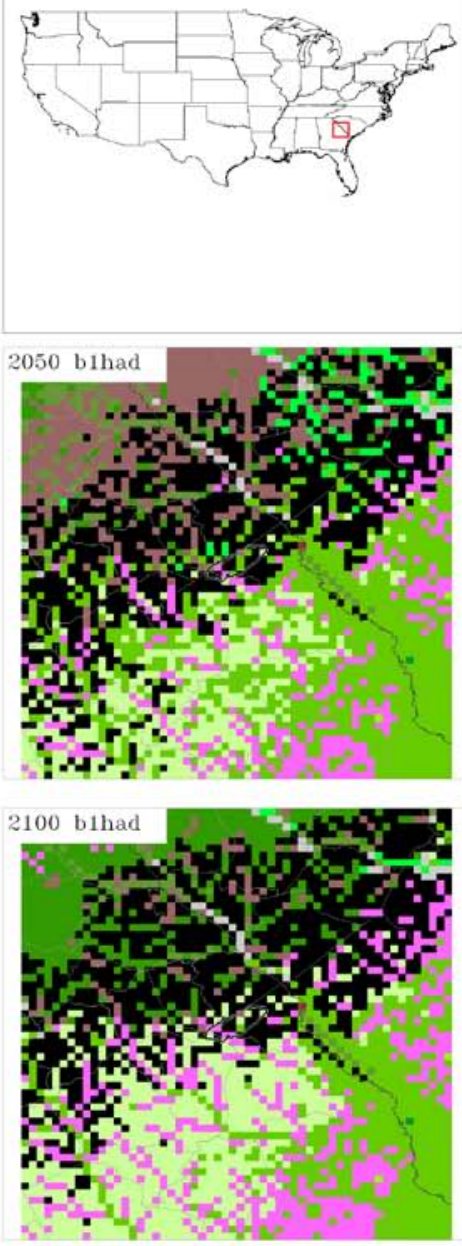
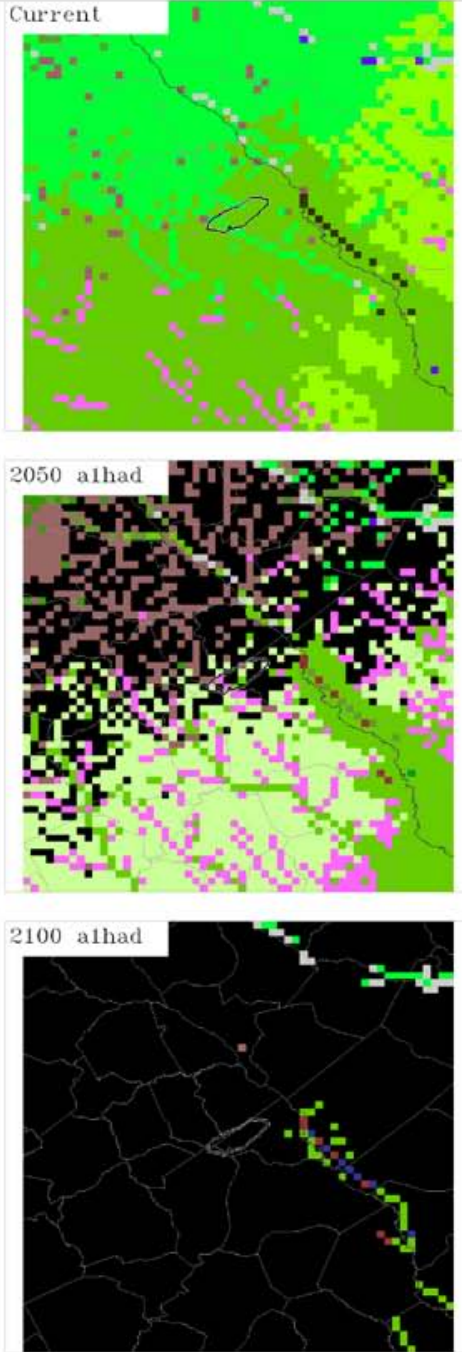
Fort Gordon

These images show where the forecasted physical and climate conditions most closely match the conditions found across the region in 2000. This answers the question, "Where can I go today to find the forecasted conditions for this installation?"
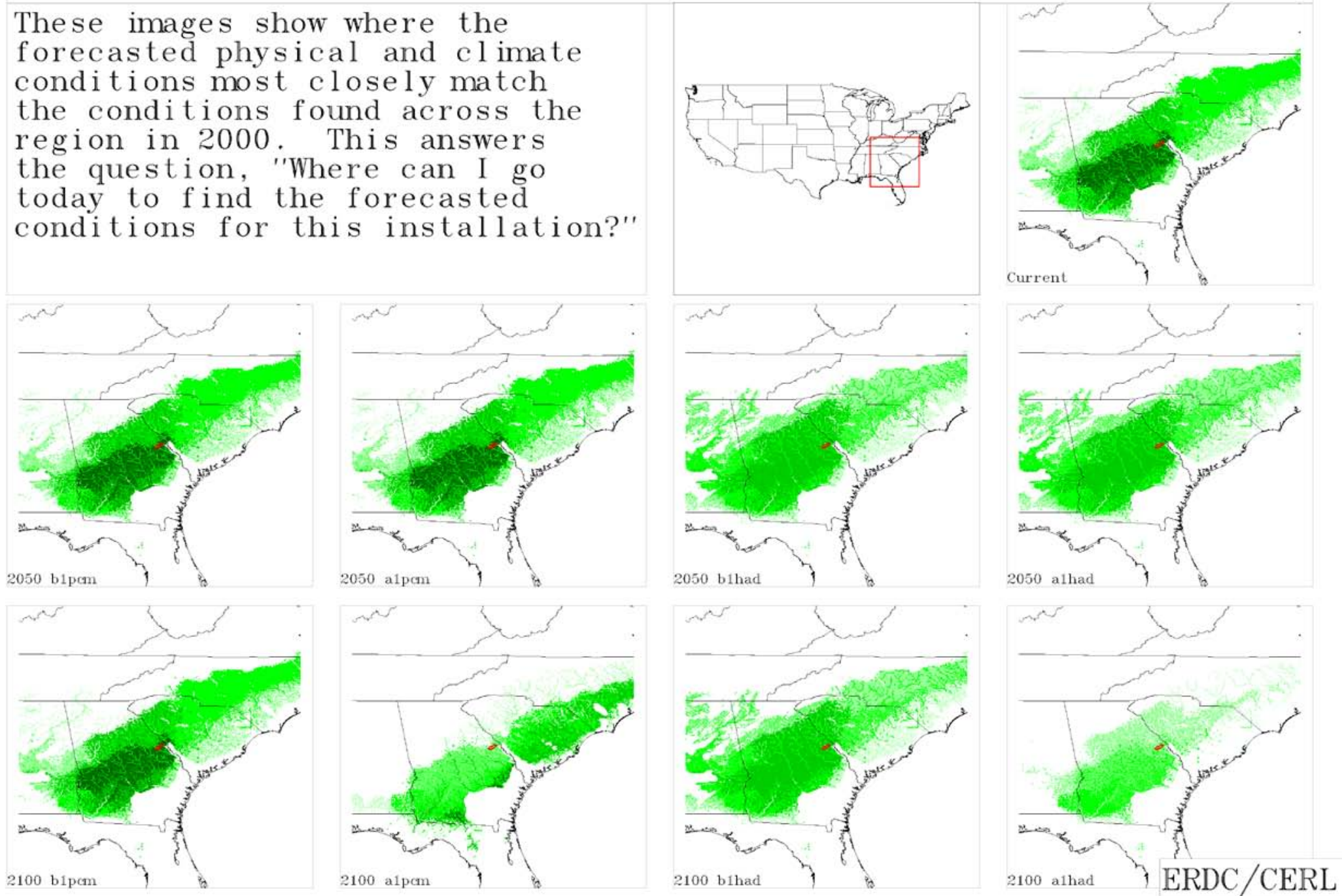

Fort Hood 
Fort Hood

\section{-0) No Current US Analog}

1201) Developed, Open Space

1202) Developed, Low Intensity

1402) Cultivated Cropland

1403) Pasture/Hay

2102) Open Water (Fresh)

4152) Edwards Plateau Limestone Savanna and Woodland

5211) Apacherian-Chihuahuan Mesqui te Upland Scrub

5216) Tamaul ipan Mesqui te Upland Scrub

5810) Western Great Plains Mesquite Woodland and Shrubland

5811) Edwards Plateau Limestone Shrubland

7602) Llano Uplift Acidic Forest, Woodland and Glade

8408) Modified/Managed Southern Tall Grassland
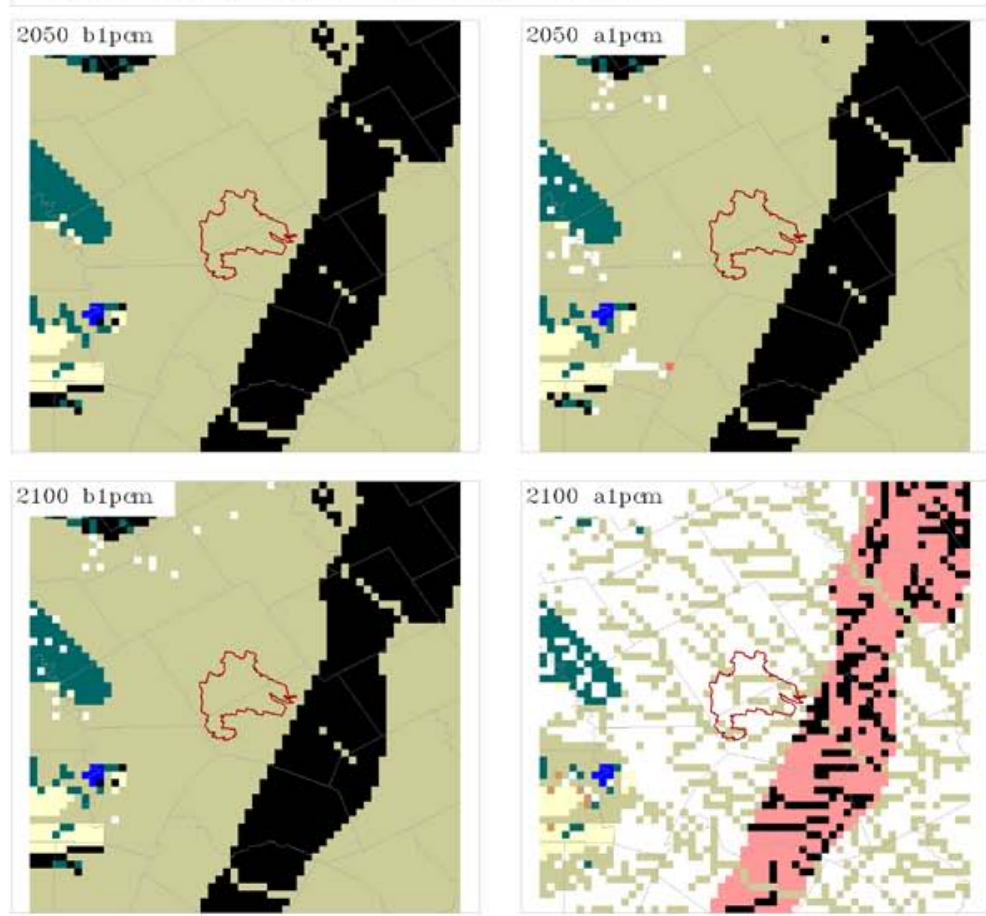
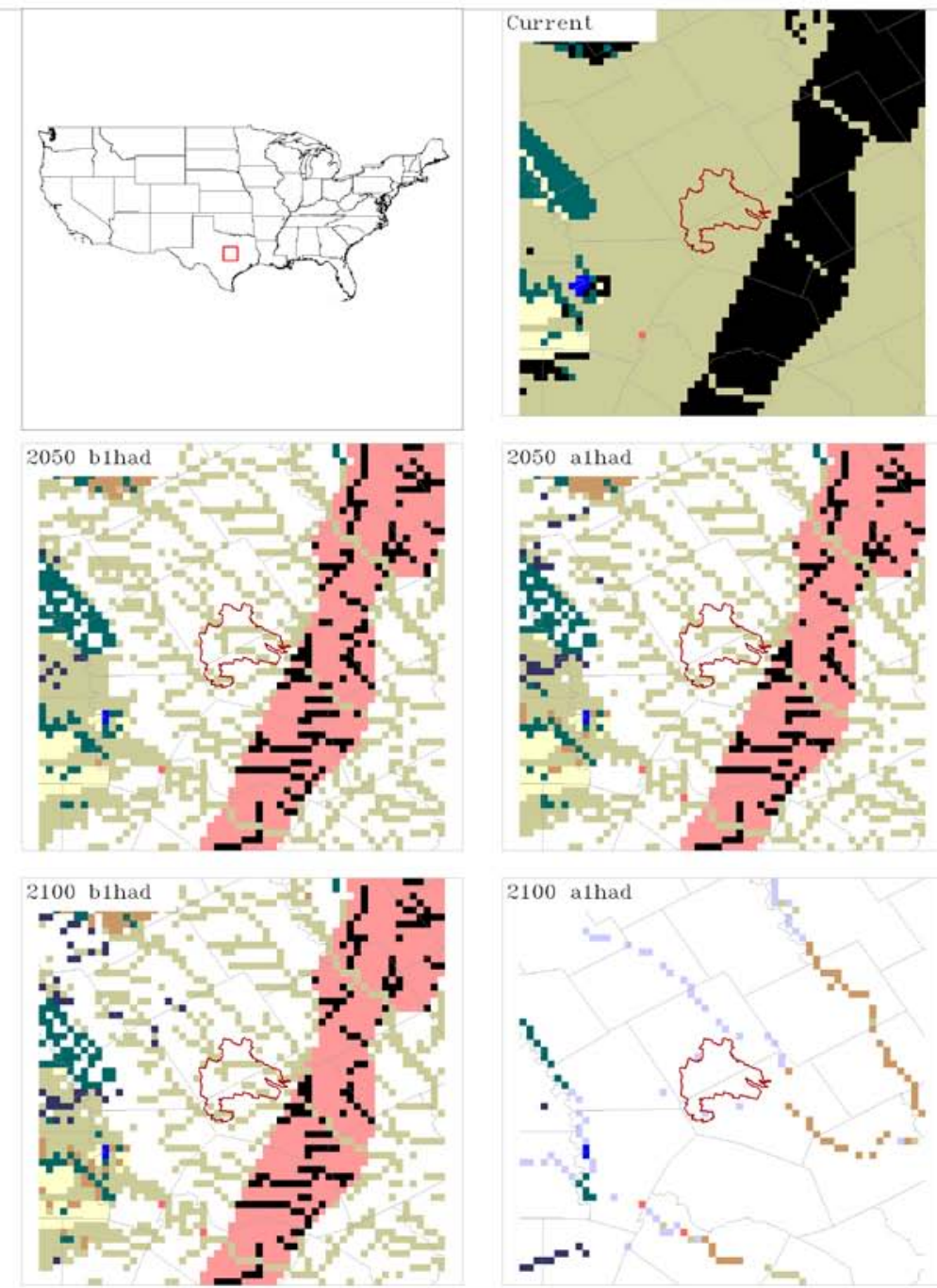
Fort Hood

0) Different from any area in the world in 2000

97) $100 \%$-Samali Acacia-Comiphora Pushlands And Thickets

155) $51 \%$-Southwestern Arabian Foothil1s Savanna

$54 \%$-Southern Shortgrass Prairic

432) $56 \%$-Espinal

- 435) $36 \%$ Humid Panpas

753) $53 \%$-Edwards Plateau

771) $53 \%$-Tamaul ipan Thorn Scrub

785) $62 \%$-Brigalor Tropical Savann

790) $76 \%$-Mitchell Grass Down

795) $77 \%$-Coolgardie Woodl and

808) $100 \%$-Great Sandy-Tanami Deser
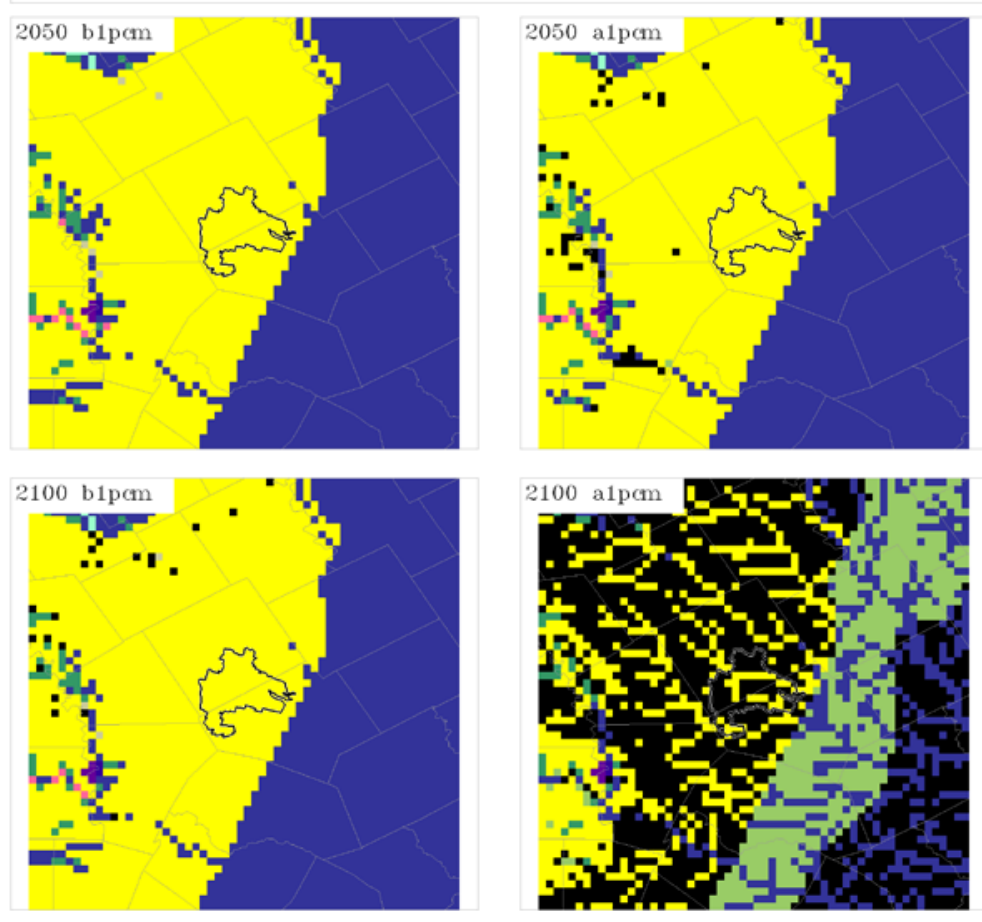
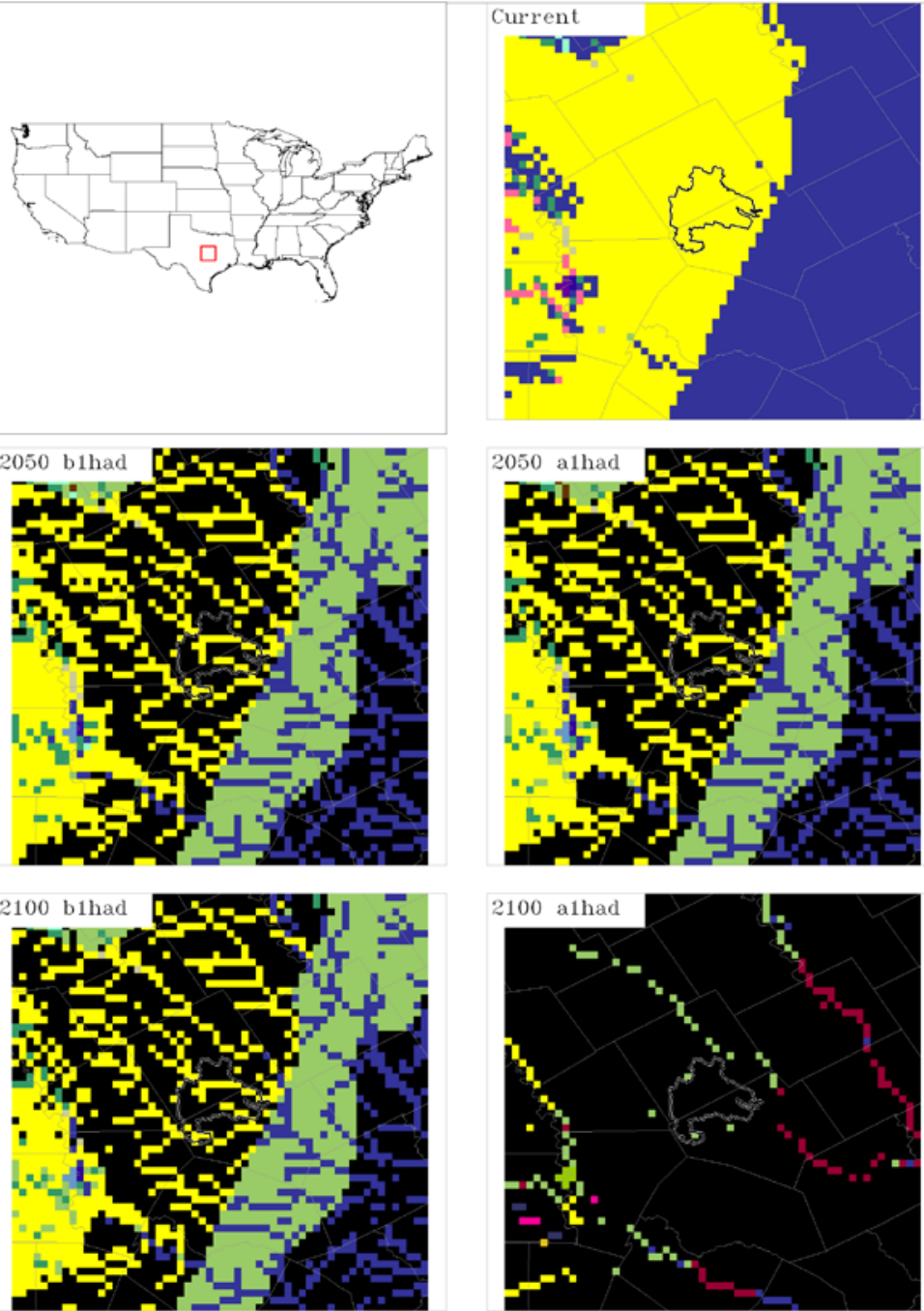


\section{Fort Hood}

These images show where the forecasted physical and climate conditions most closely match the conditions found across the region in 2000. This answers the question, "Where can I go today to find the forecasted conditions for this installation?"
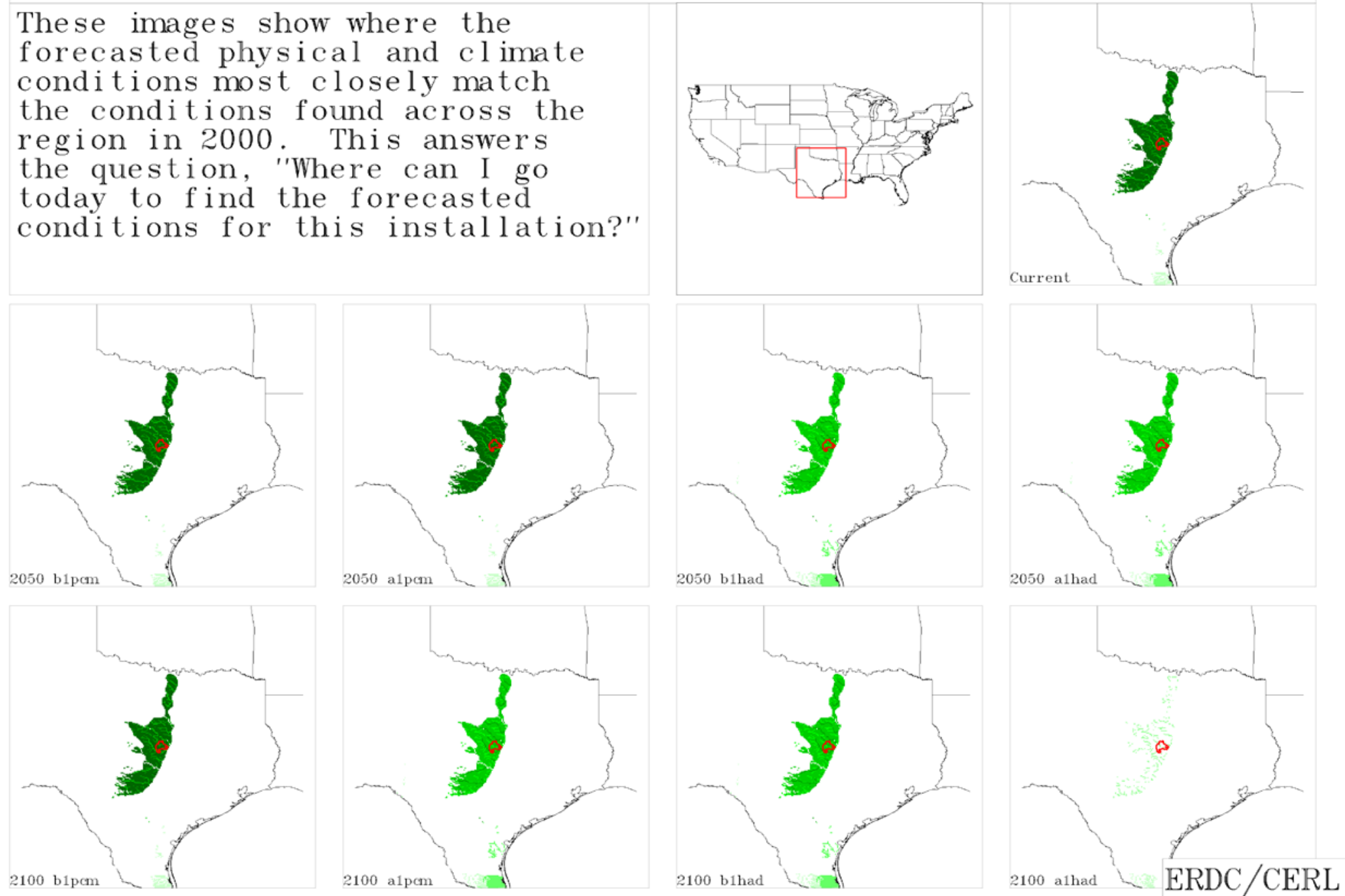

Fort Huachuca 
Fort Huachuca

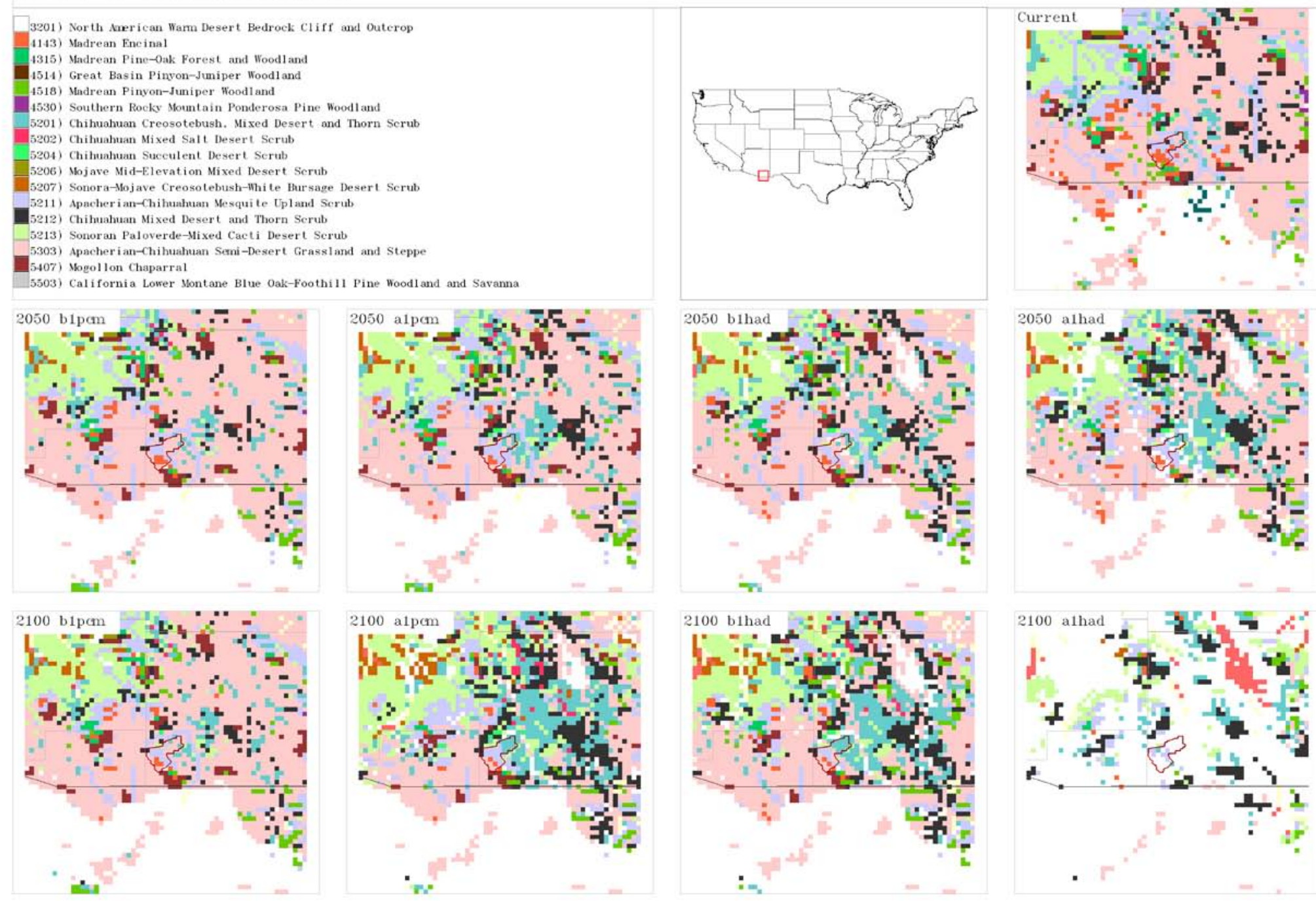


Fort Huachuca

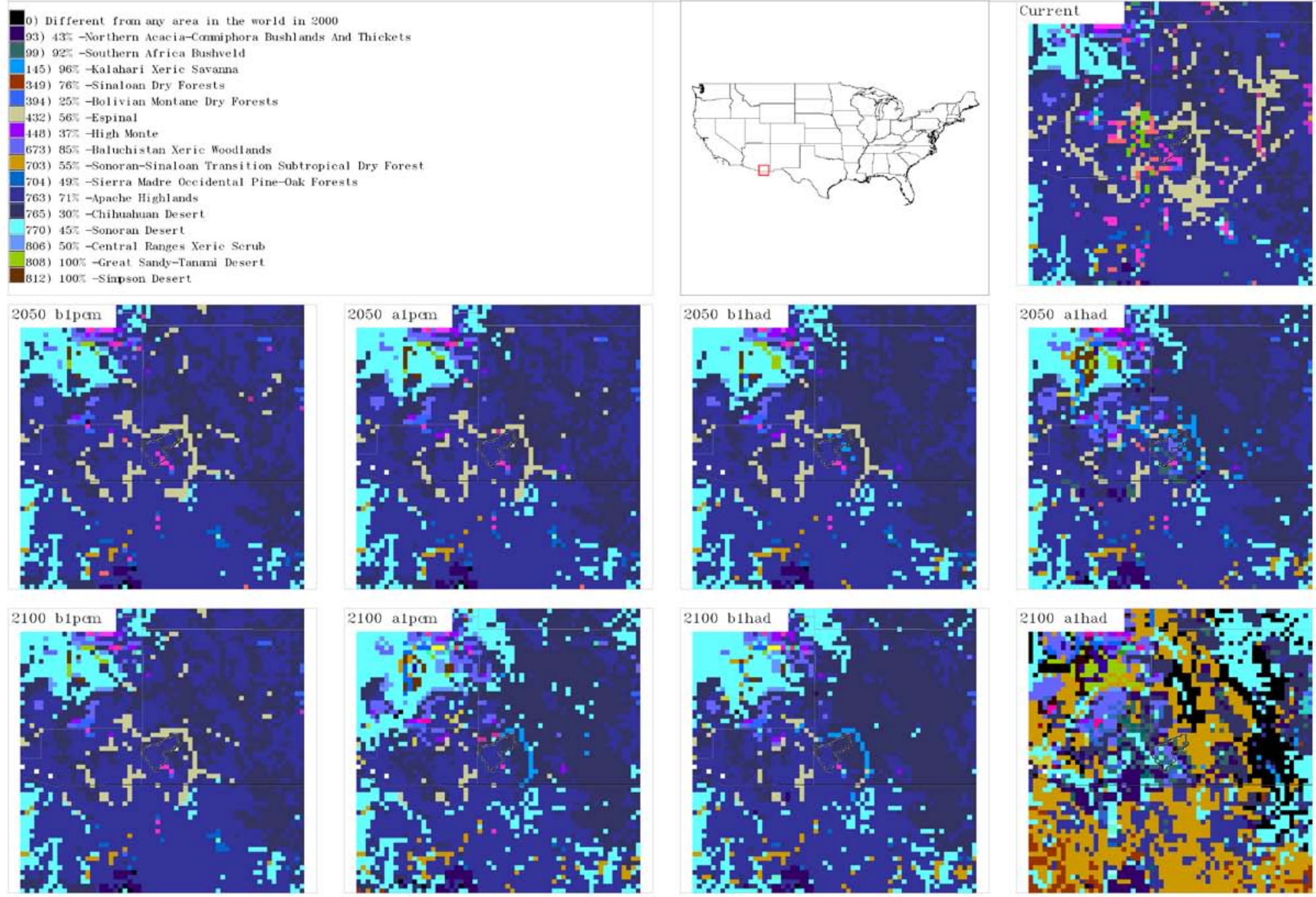




\section{Fort Huachuca}

These images show where the

forecasted physical and climate conditions most closely match

the conditions found across the region in 2000. This answers the question, "Where can I go today to find the forecasted conditions for this installation?"
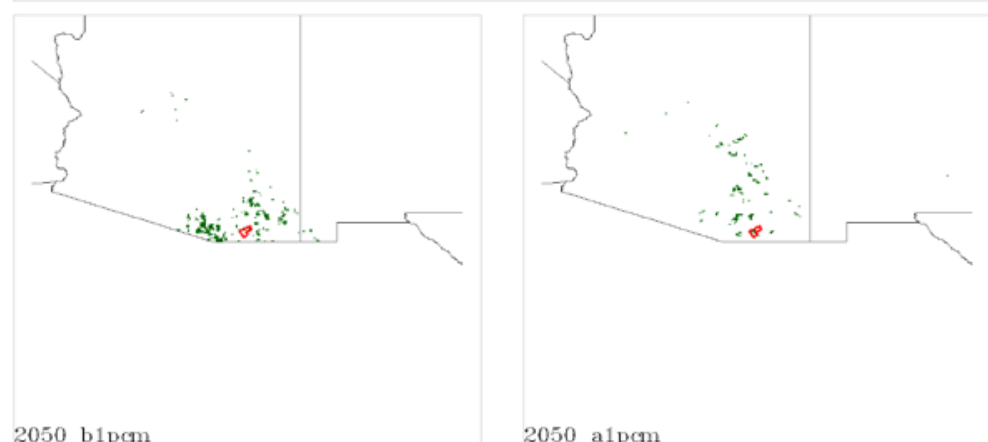

$2050 \mathrm{~b} 1 \mathrm{pcm}$

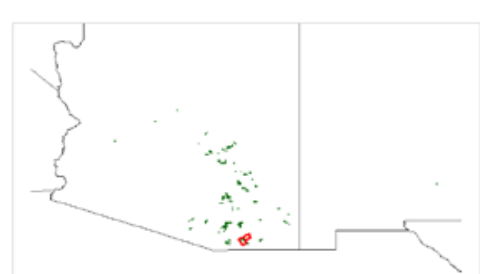

$2100 \mathrm{~b} 1 \mathrm{pcm}$
2050 a1pcm

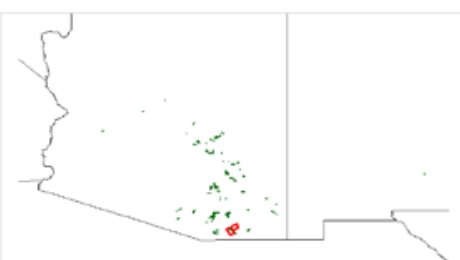

$2100 \mathrm{a} 1 \mathrm{pcm}$
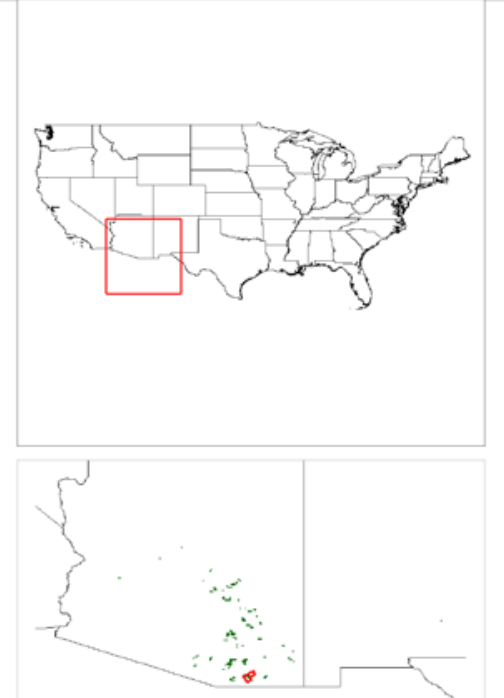

2050 b1had

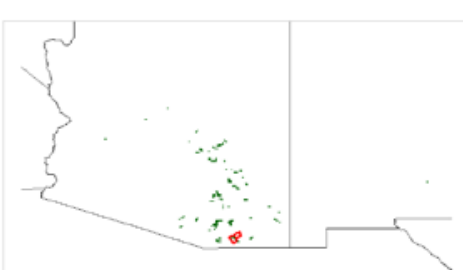

2100 b1had
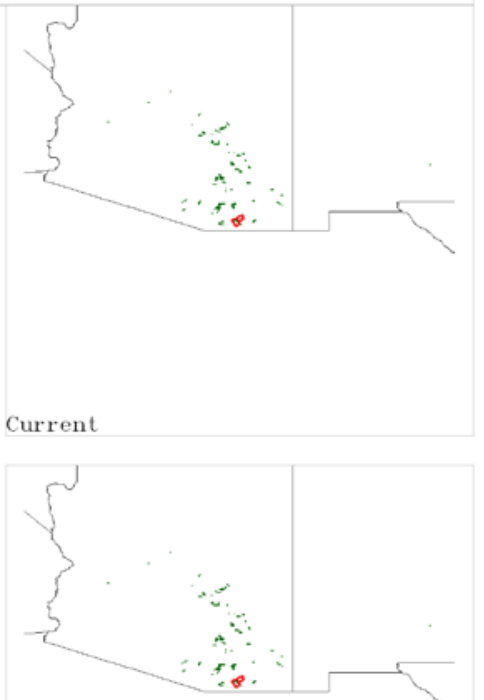

2050 alhad

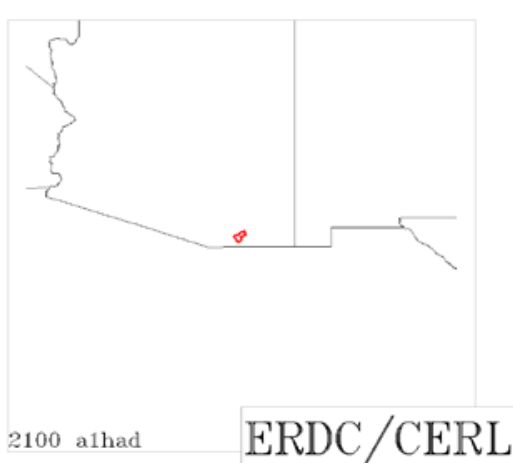

Hunter-Liggett Military Reservation 
0) No Current US Analog
1201) Developed. Open SP

1201) Developed. Open Space
1203) Developed. Medium Intensity

1402) Cultivated Cropland
3201) North Amrican Warm Desert Bedrock Cliff and Outcrop

4404) Mediterranean Cal i fornia Mesic Serpentine Woodl and and Chaparral

4518) Madrean Pinyon-Jumiper Moodland

4519) Mediterranean California Dry-llesic Mixed Conifer Forest and Woodland

5207) Sonora-Mojave Creosotebush-llhi te

5211) Apacheri an-Chihuahuan Mesqui te Upland Scrul

5213) Sonoran Paloverde-Mixed Cacti Desert Ser
5410) Southern California Dry-Mesic Chaparral

-
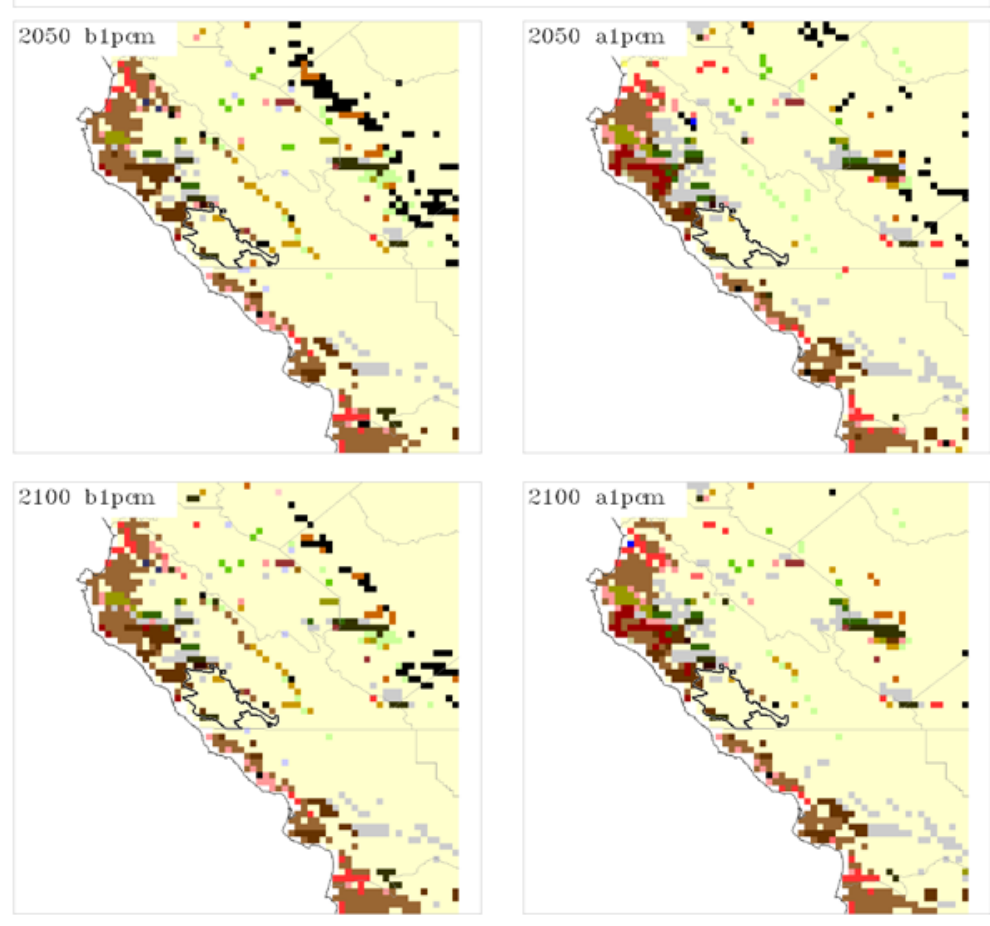
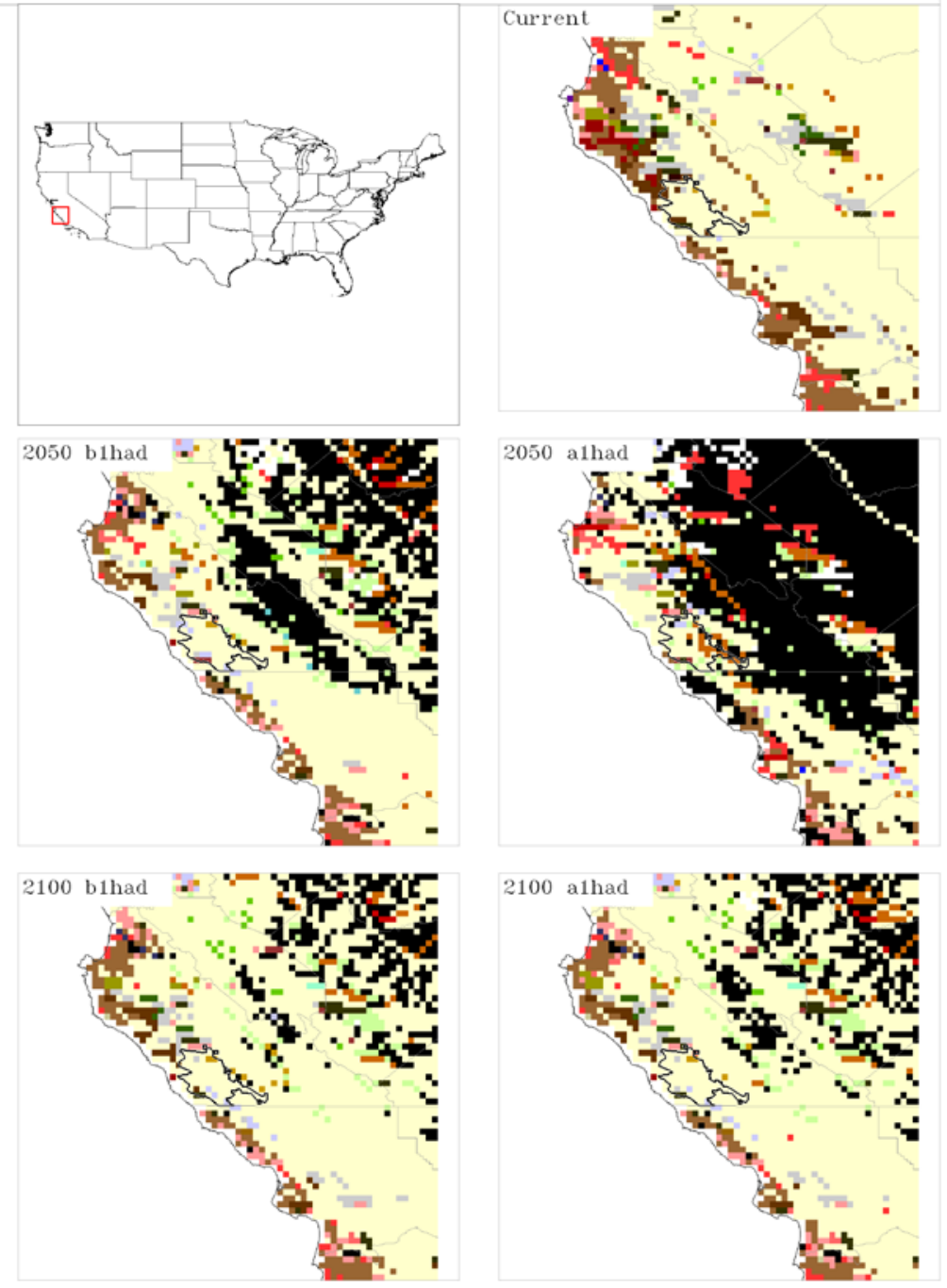
Hunter-Liggett Mili tary Reservation

0) Different from any area in the world in 2000

- 150) 58: - Tam Karoo

452) $45 \%$-Chilean Matorral

573) 27: -Zagros Mountains Forest Steppe

口655) $31 \%$-Aegean And Western Turkey Sclerophyllous And Mixed Forests

666) 55\% -Hediterranean Acacia-Argania Dry Hoodlands And Succulent Thicke

668) $36 \%$ - Hedi terranean Woodl ands And
673) $85 \%$ - Baluchistan Xeric Woodl ands

- 693 50.

760) $98 \%$-California Central Coast
761) $49 \%$-cali fornia South Coast

762) $37 \%$-Great Central Valley
$797) 54 \%$-Eyre And York Mallee
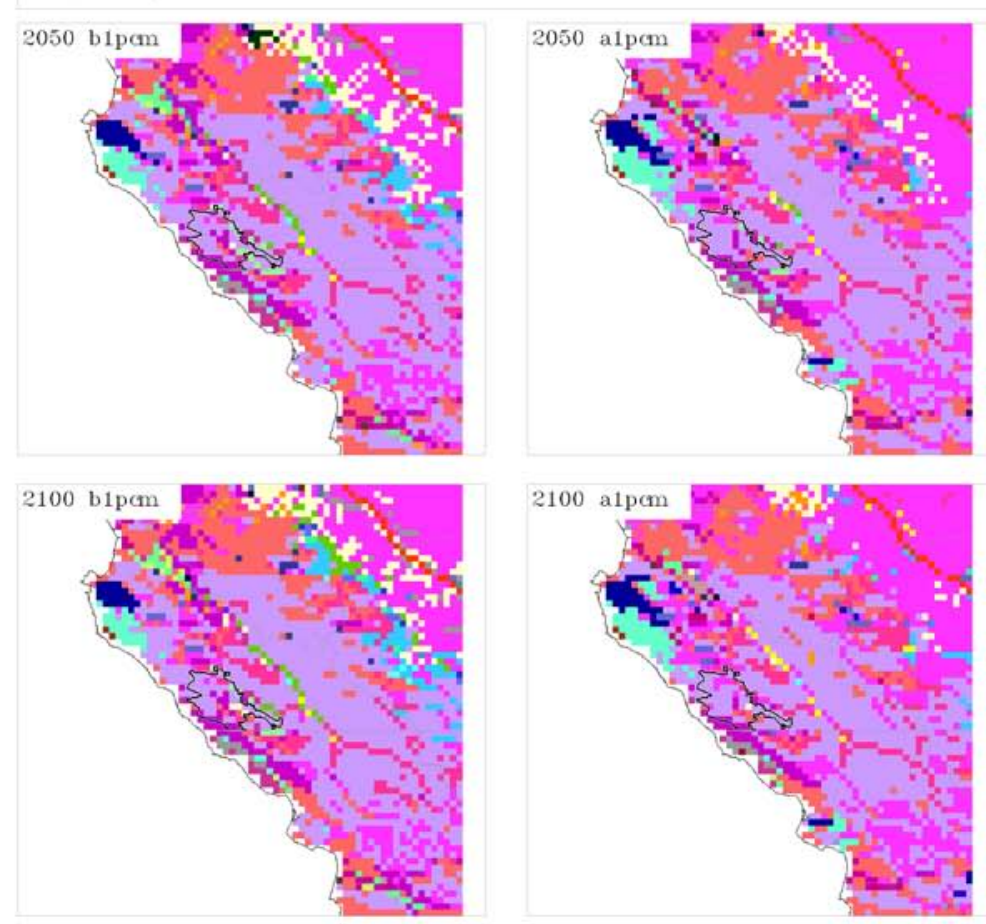
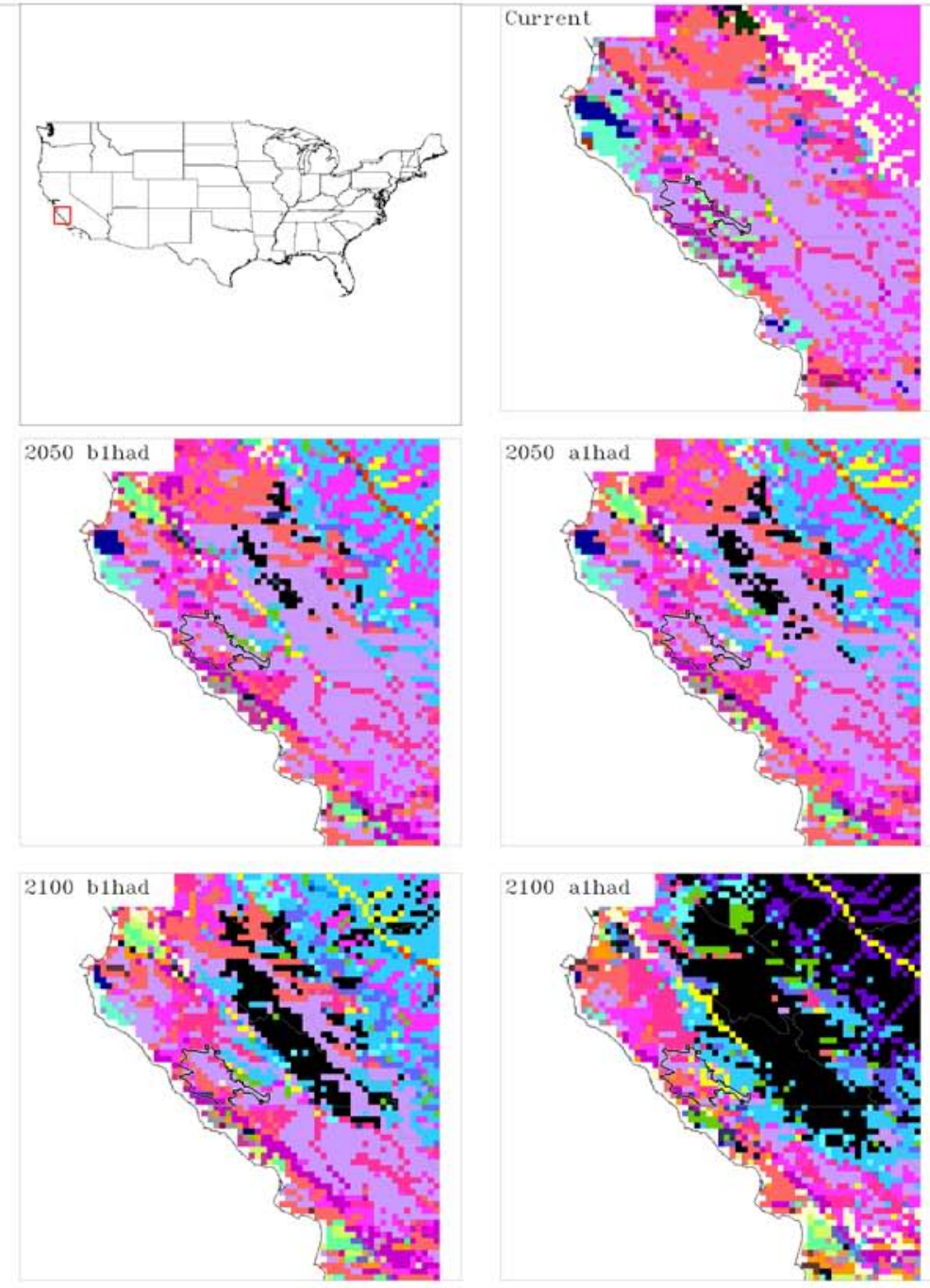
Hunter-Liggett Mil i tary Reservation

These images show where the

forecasted physical and climate conditions most closely match

the conditions found across the region in 2000. This answers the question, "Where can I go today to find the forecasted conditions for this installation?"

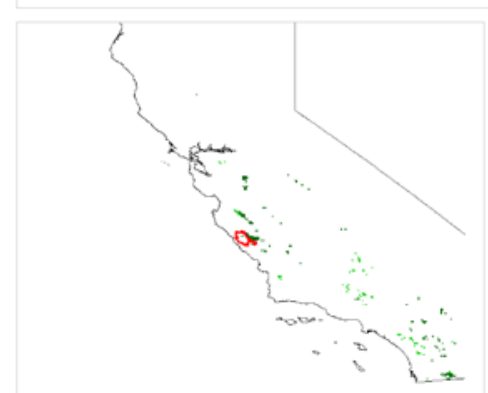

$2050 \mathrm{~b} 1 \mathrm{pcm}$
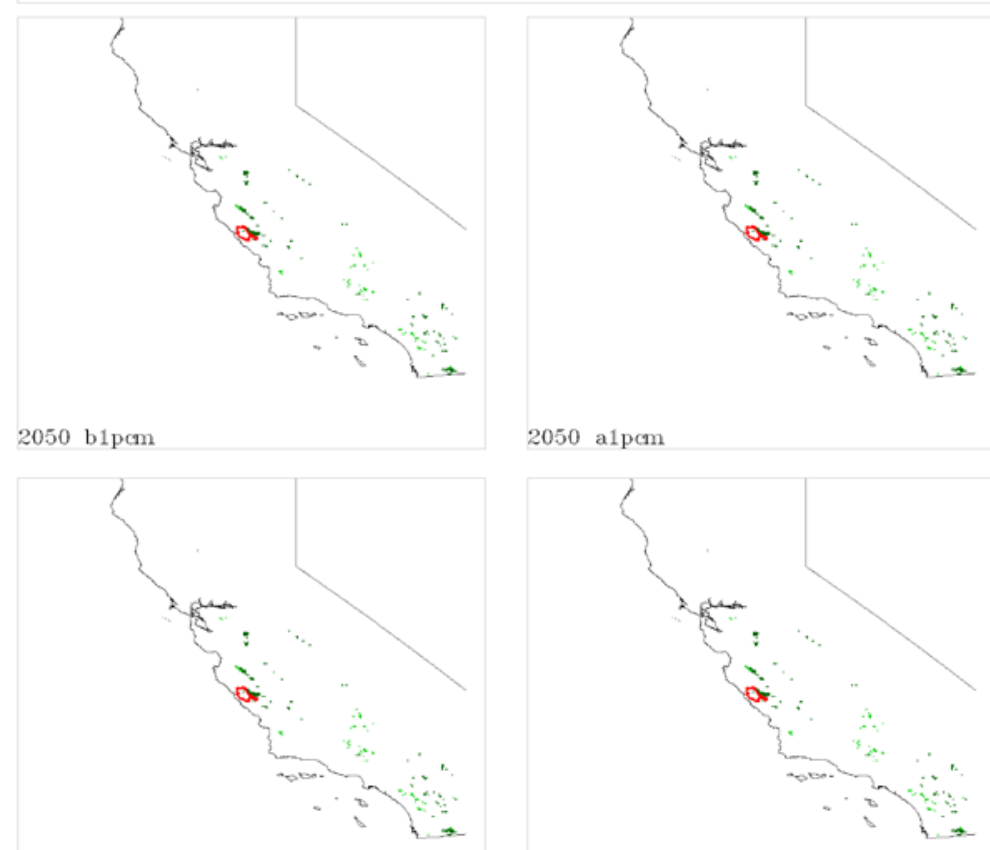

$2050 \mathrm{a}$ pam
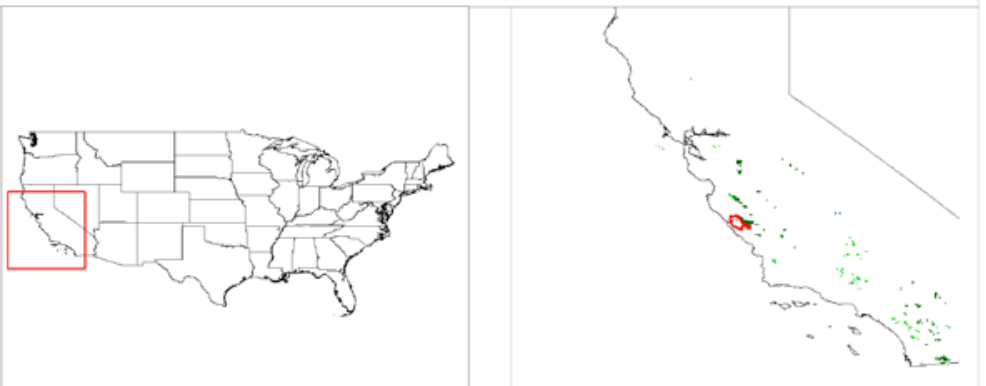

Current

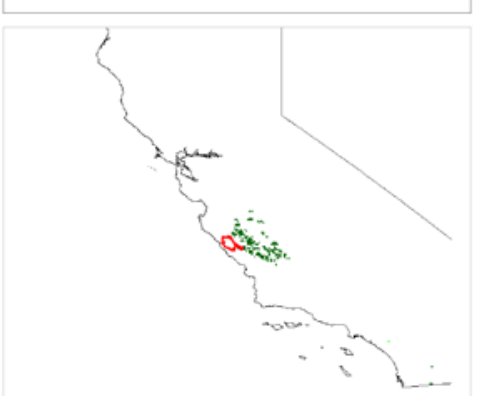

2050 b1had

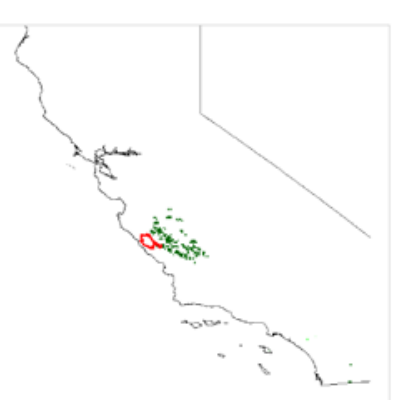

2050 a1had

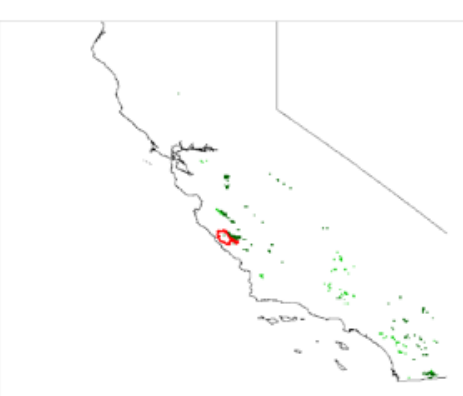

$2100 \mathrm{a} 1 \mathrm{pcm}$

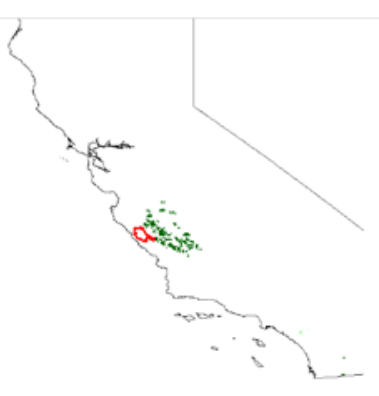

2100 b1had

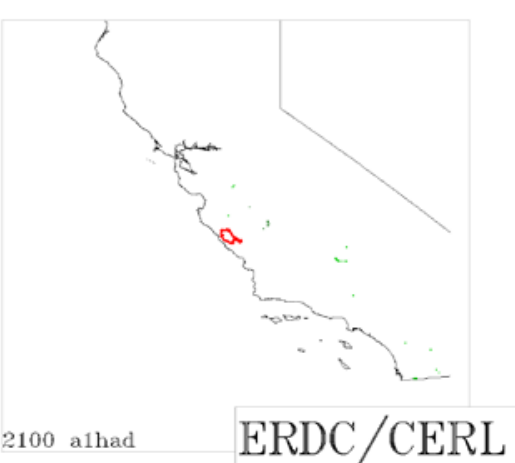

\section{Fort Irwin}


Fort Irwin

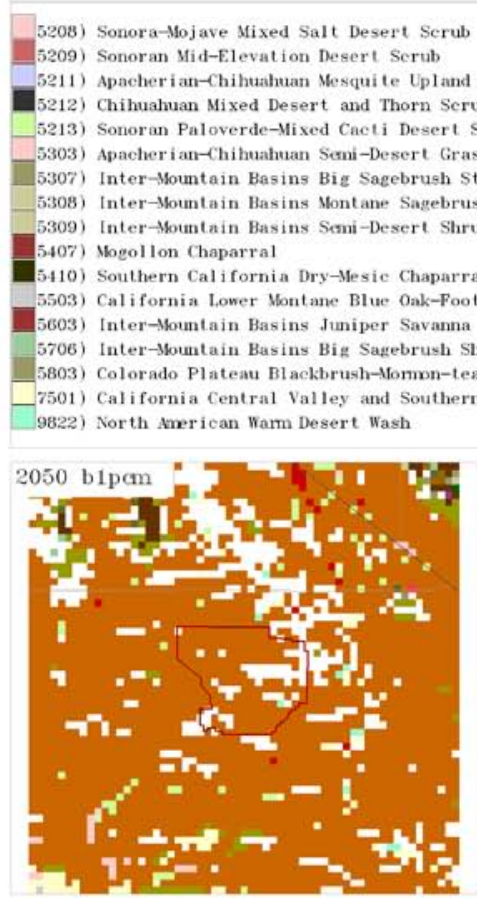

$2100 \mathrm{~b} 1 \mathrm{pcm}=7 \mathrm{H}$ ! $\mathrm{F}$

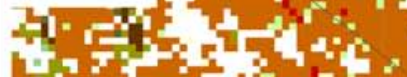

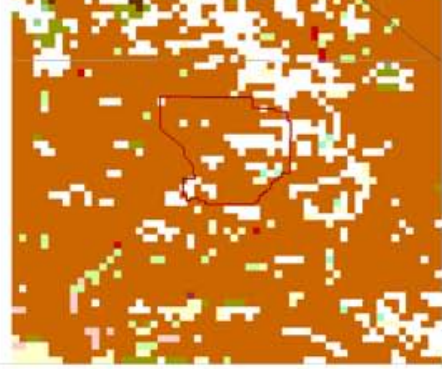

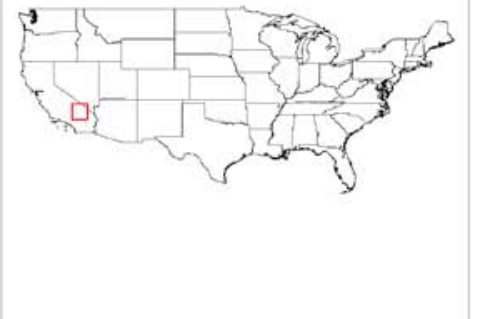

2050 blhad 7 Ther

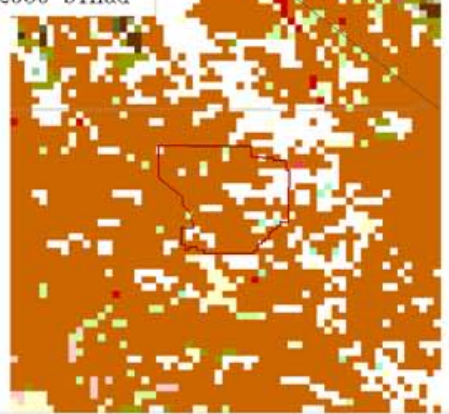

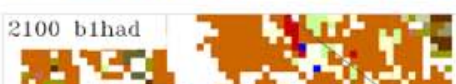

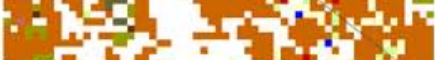

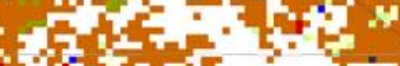
군 -7 - $-17 \mathrm{y}$

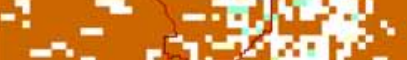
-7 둔

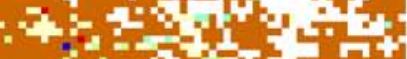
$2 x^{2} x^{2}=0$

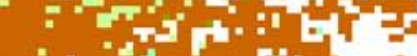

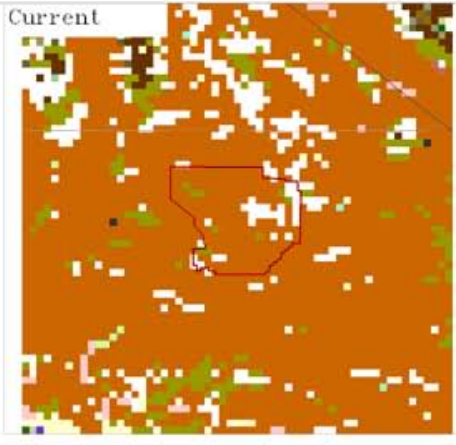

2050 alhad $7+4=$

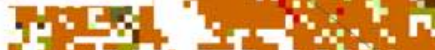
tris: Fr: $=-2, y$ $=0$. .. -

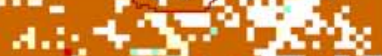

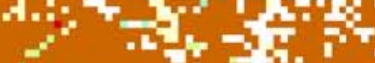
1.

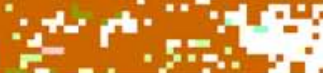

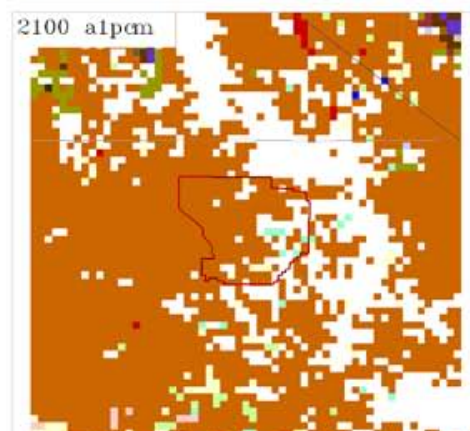
xh- 
Fort Irwin

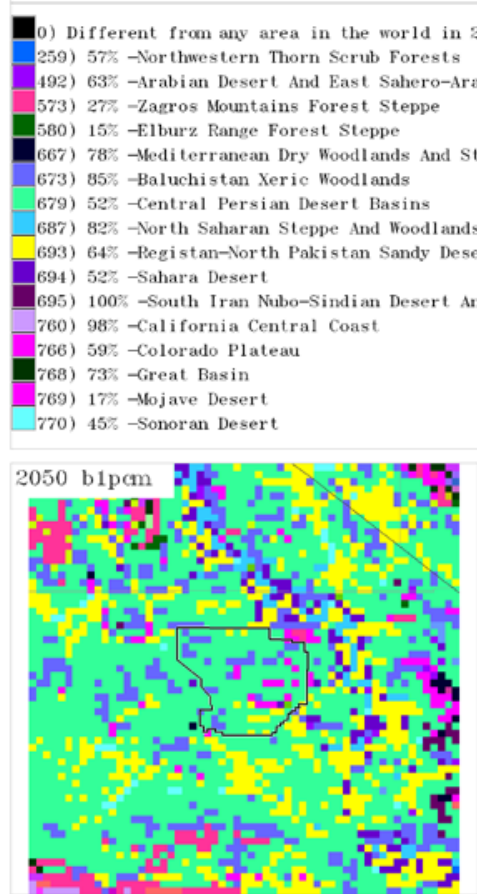

2100 b1pcm PF if:-

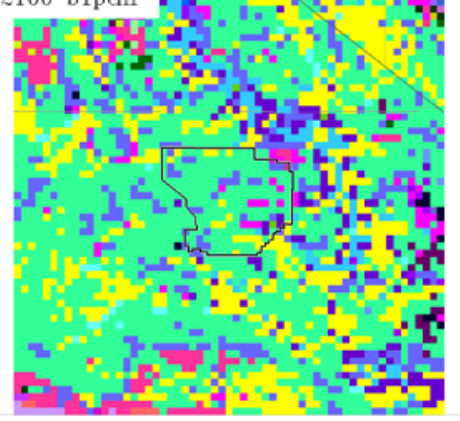

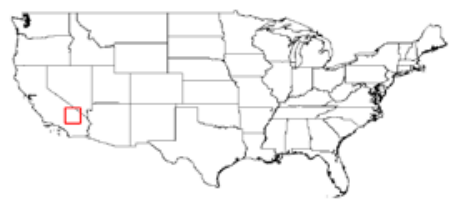

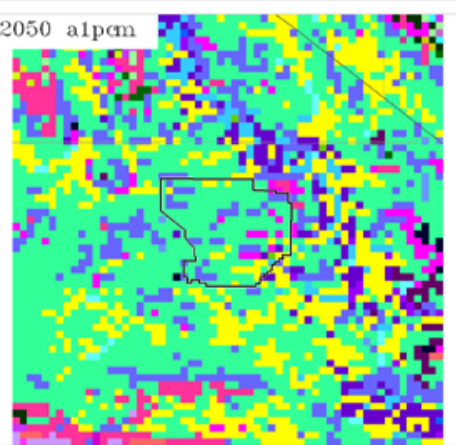

2100 a1pcm $\mathbf{m}=\mathbf{F}+\mathbf{4}$
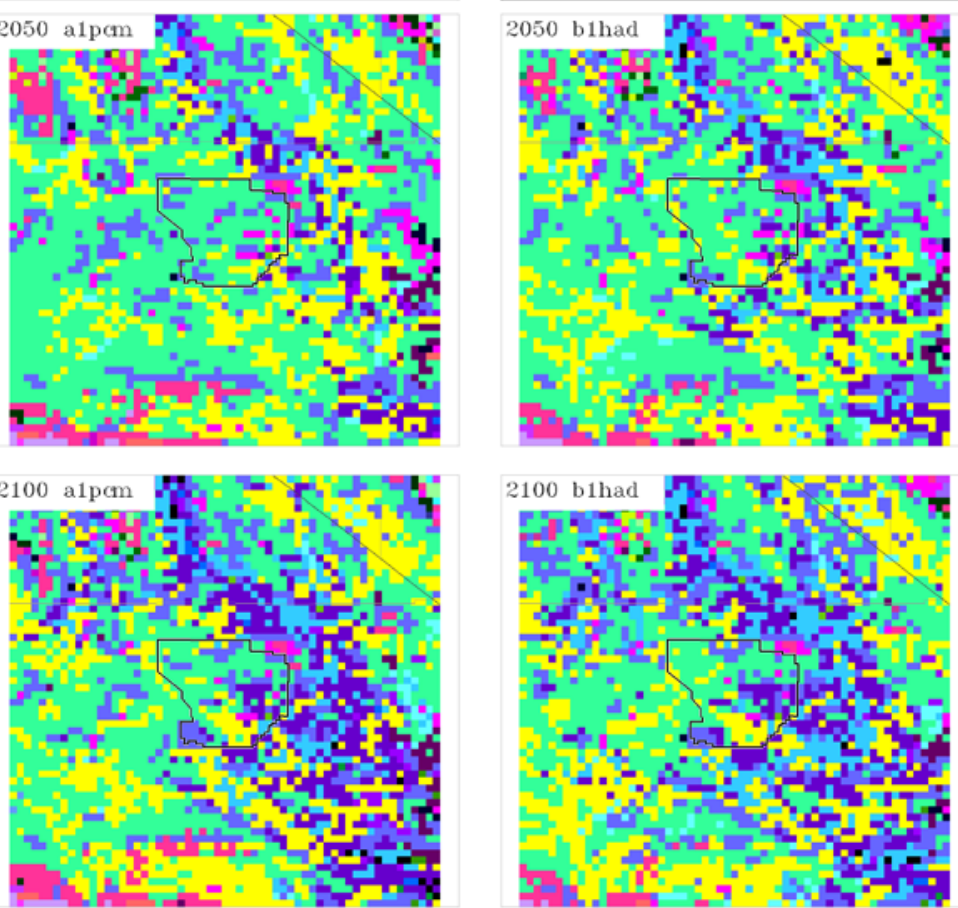

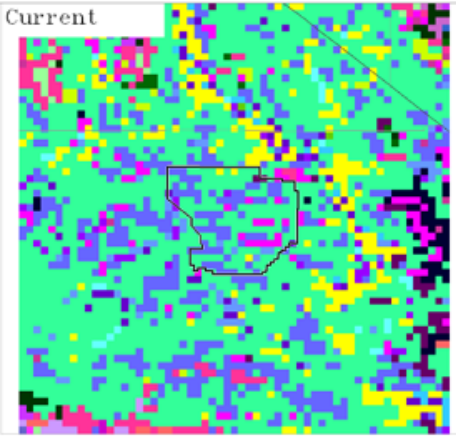

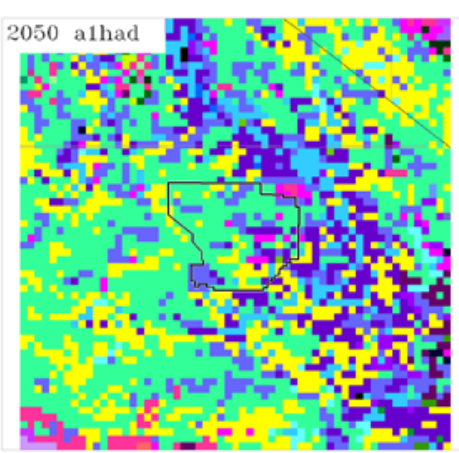

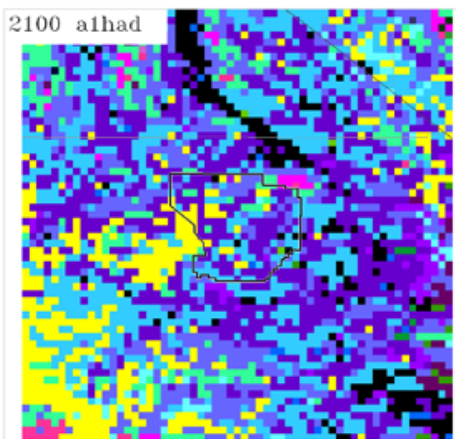




\section{Fort Irwin}

These images show where the forecasted physical and climate conditions most closely match the conditions found across the region in 2000. This answers the question, "Where can I go today to find the forecasted conditions for this installation?"
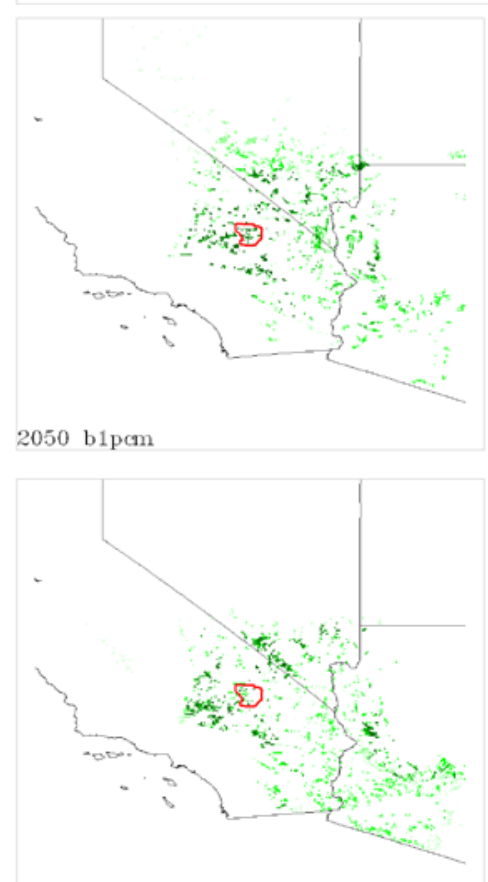

$2100 \mathrm{~b} 1 \mathrm{pcm}$
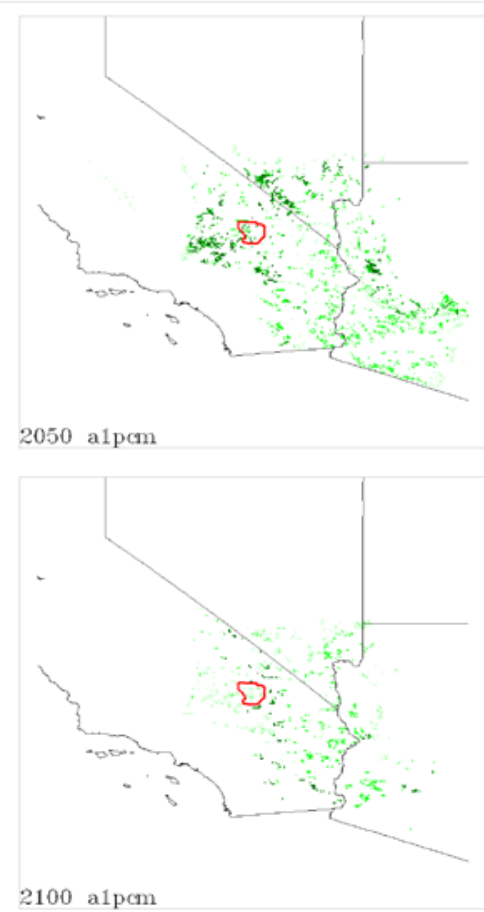
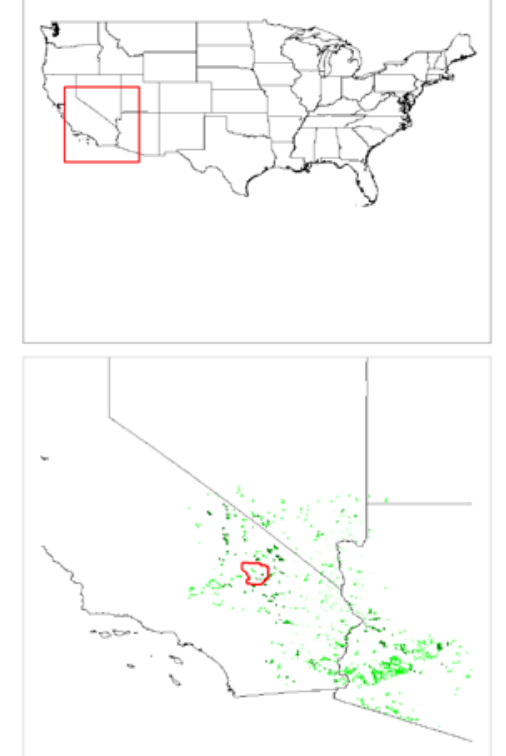

2050 b1had

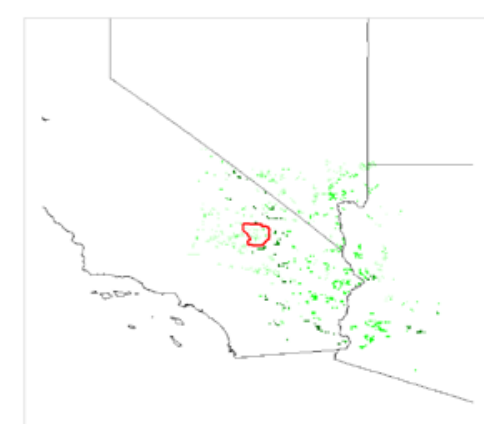

2100 b1had

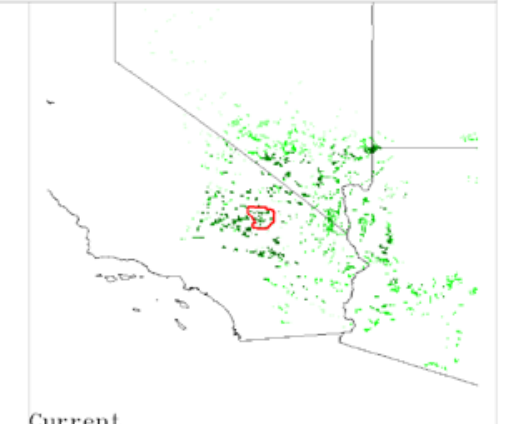

Current

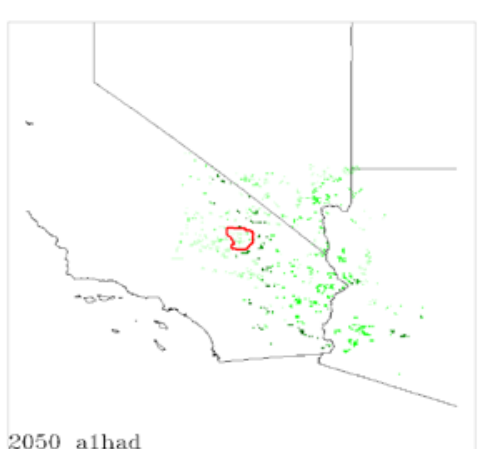

2050 alhad

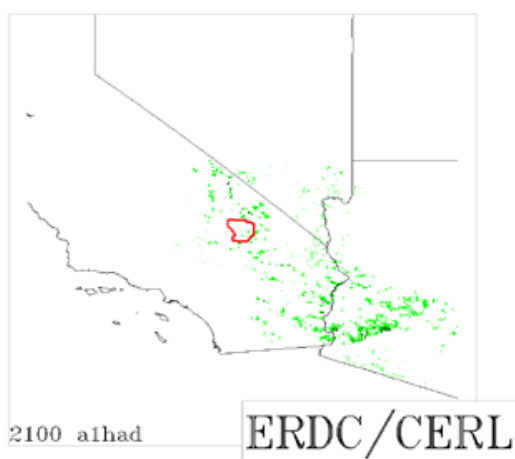

Fort Jackson 
Fort Jackson

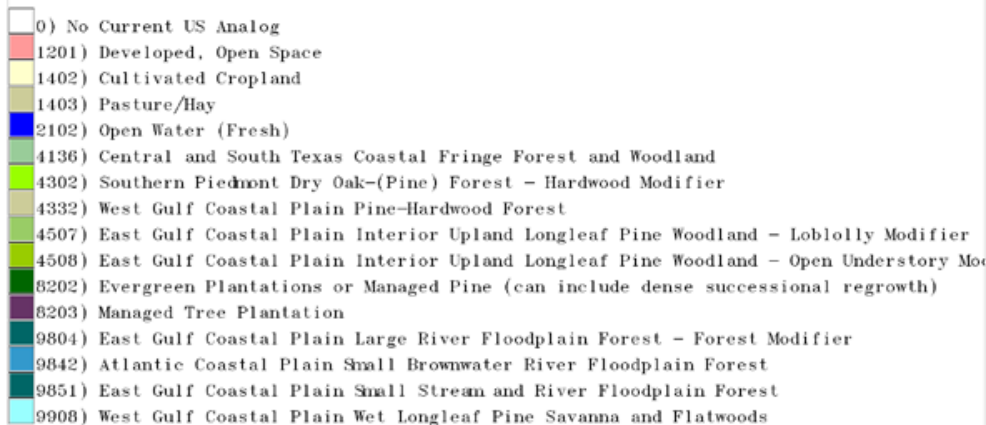

4507) East Gulf Coastal Plain Interior Upland Longleaf Pine Woodland - Loblolly Modifier 4508) East Gulf Coastal Plain Interior Upland Longleaf Pine Woodland - Open Understory N 8202) Evergreen Plantations or
8203) Managed Tree Plantation

9804) East Gulf Coastal Plain Large River Floodplain Forest - Forest Modifier

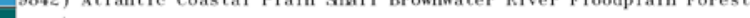

-9908) West Gulf Coastal Plain Wet Longleaf Pine Savar Floodplain Fores
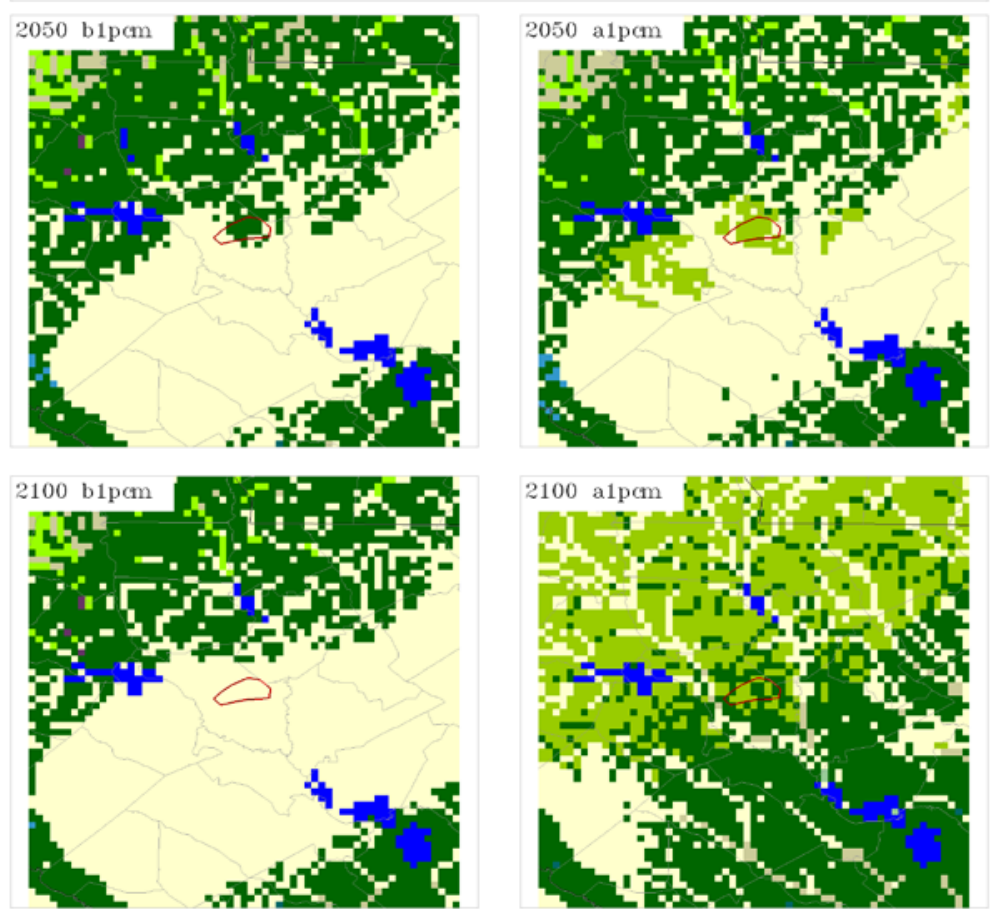
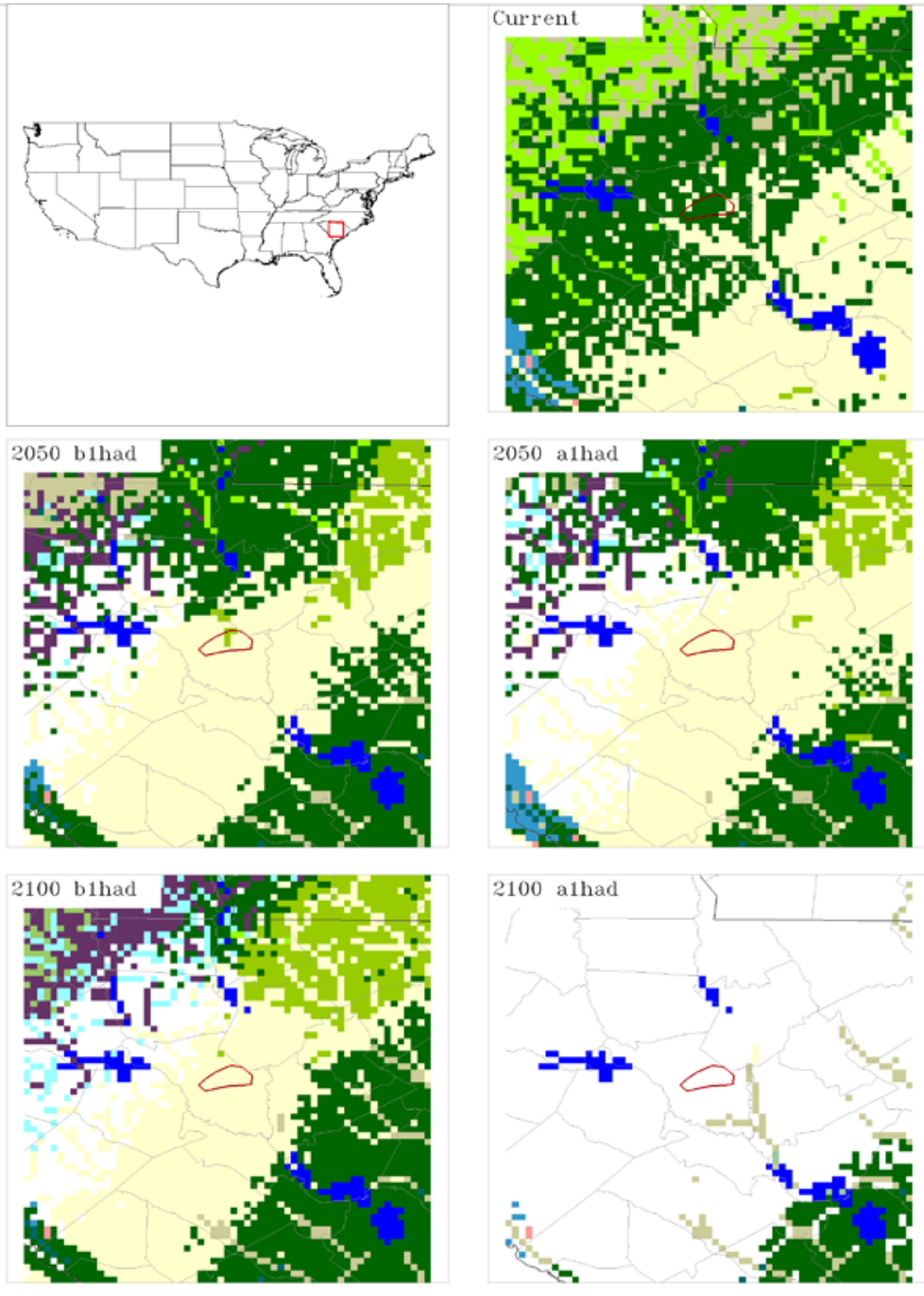
Fort Jackson

D) Different from any area in the world in 2000

-98) 45 -Southern Acacia-Commiphora Busblands And Thicket

185) 768 -Ouachi ta Mountains

antic Forest

355) 740 -Tropical Florida
431) 70 - trueuayan Savanna

499) 90: -East Gulf Coastal

(50) 33i - Florida Peninsula

503) 812 -Mid-Atlantic Coastal Plain

707) 30\% -Cinberlands And Southern Ridge And Valley

715) 315 - toper East Gulf Coastal Plain

727) 82\% -South Atlantic Coastal Plain

729) 84\% -tipper West Gulf Coastal Plain
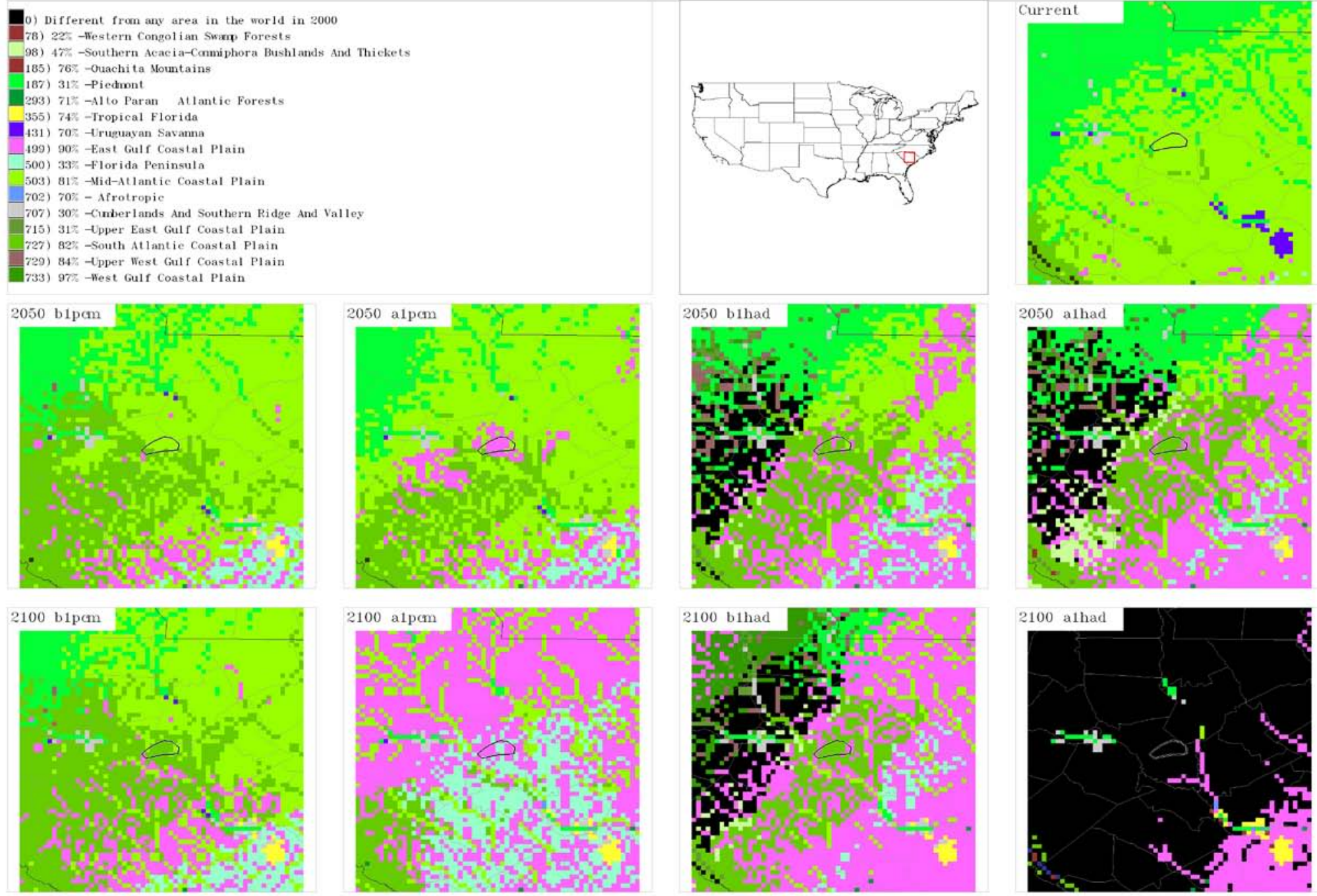
Fort Jackson

These images show where the forecasted physical and climate conditions most closely match the conditions found across the region in 2000. This answers the question, "Where can I go today to $\mathrm{f}$ ind the forecasted conditions for this installation?"
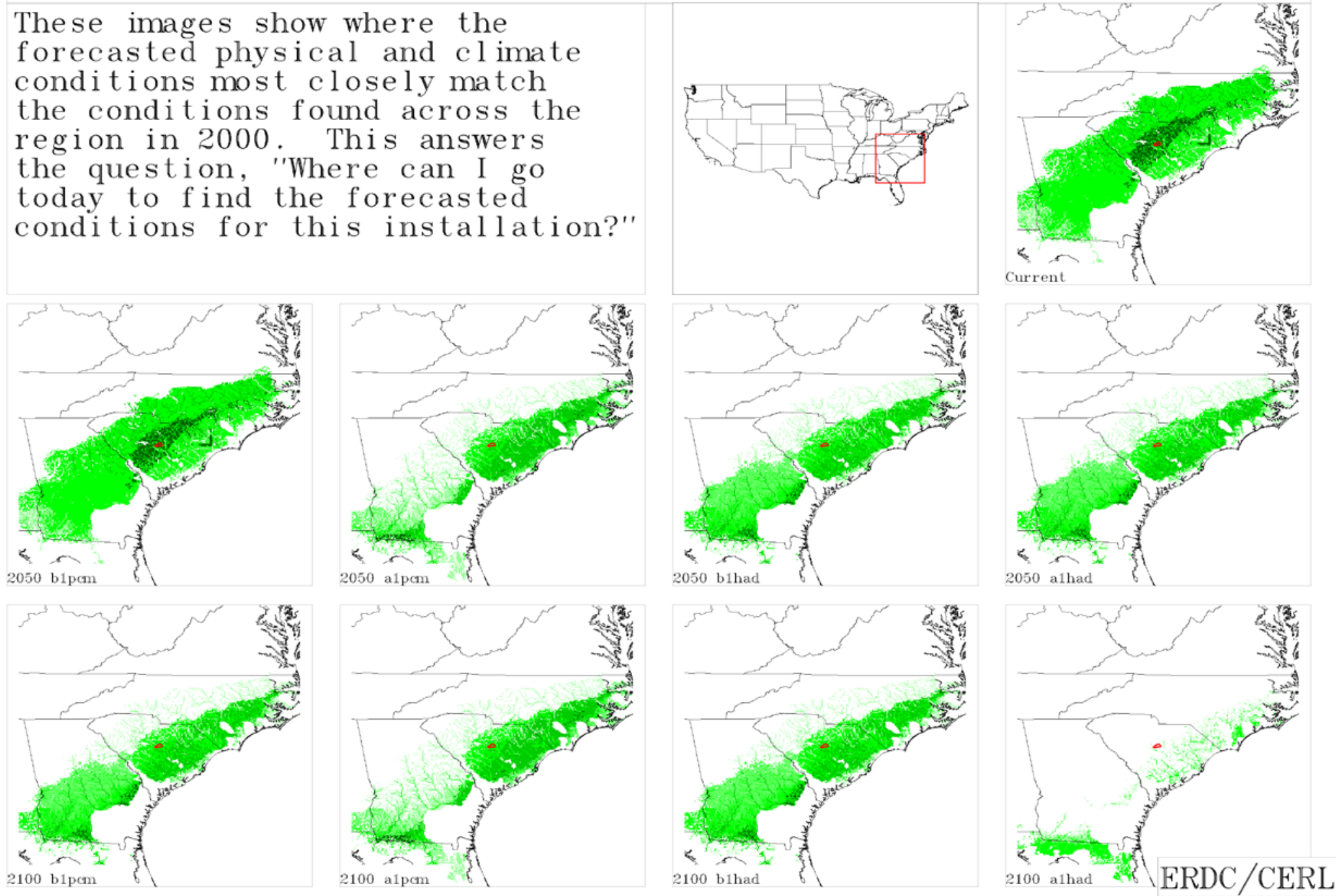

Fort Knox 
Fort Knox

4115) Ozark-Ouachita Dry-kesic Oak Forest

1416) Southern Interior tou Plateau Dry-Mesic Oak Fores

1126) Allegheny-Cunterland Dry Oak Forest and Woodl and - Hardrood

1302) Southern Piedonnt Dry Oak-(Pine) Forest - Hardwood Modifier

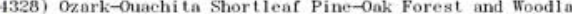

4350) Central Appalachian Oak and Pine Porest

4332) Nest Gulf Coastal Plain Pine-Hardwood Forest

401) Southern and Central Appalachian Cove Forest

4402) South-Central Interior Mesophytic Forest

$4507)$ East Gulr Coastal Plain Interior Upland Longlear Pine Moodland - Loblolly Nodifier

9804) East Gulf Coastal Plain Large. River Floodplain Forest - Forest Modifier

9842) Atlantic Coastal Plain Small Bronnwater River Floodplain Forest

9851) East Gulf Coastal Plain Smll Strean and River Floodplain Forest
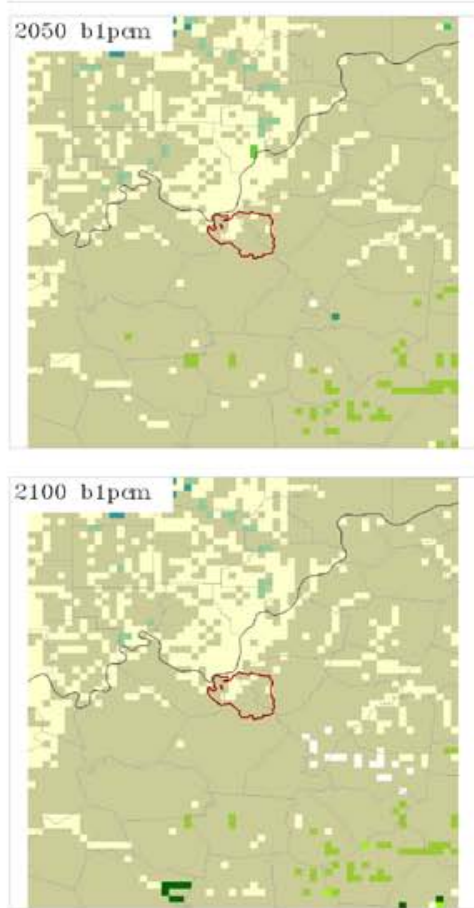
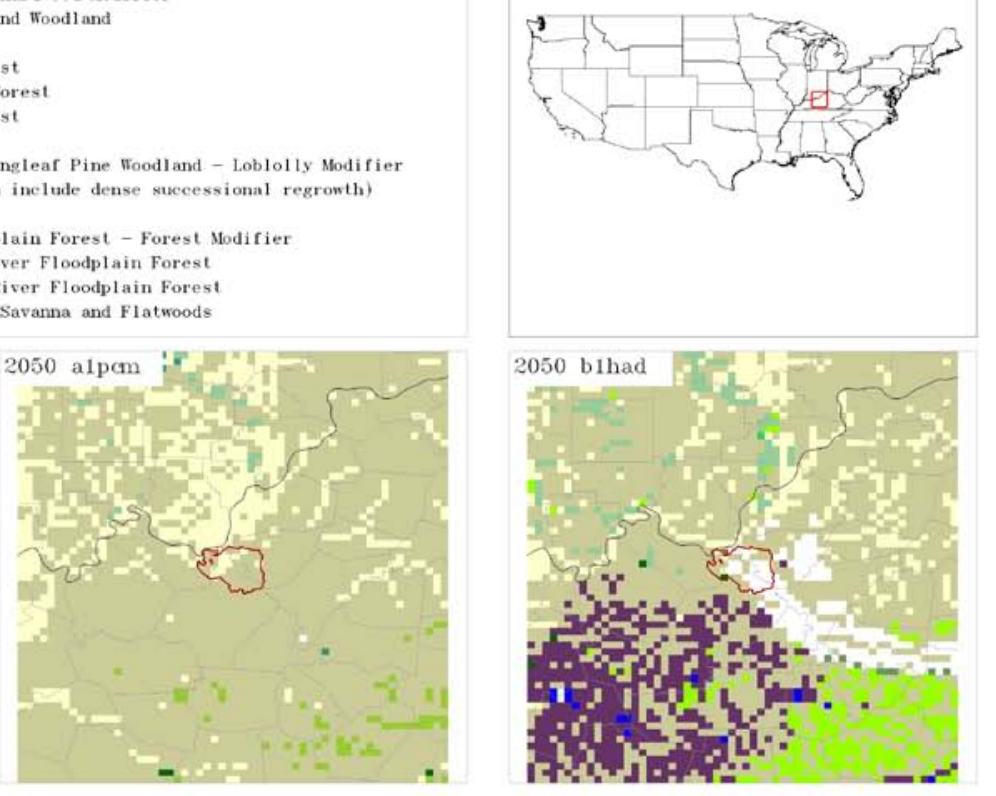

2100 a1pom $z^{2}=$ "1

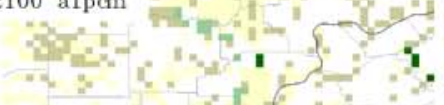
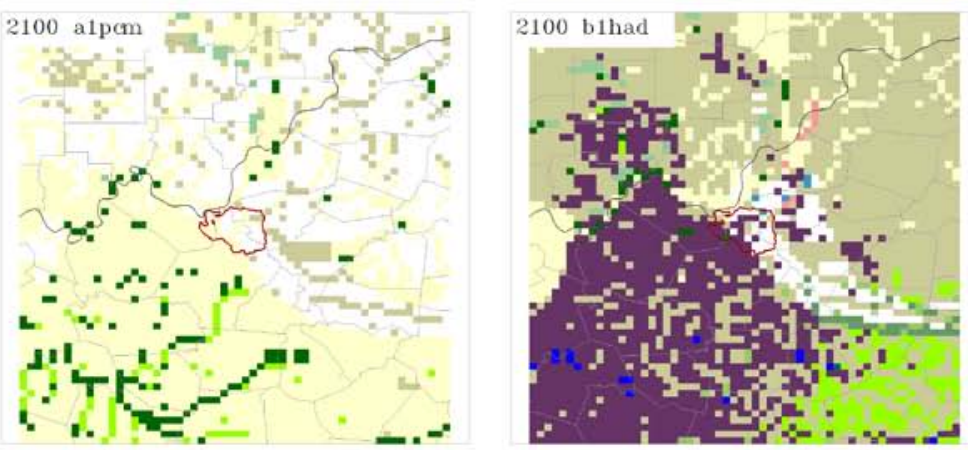
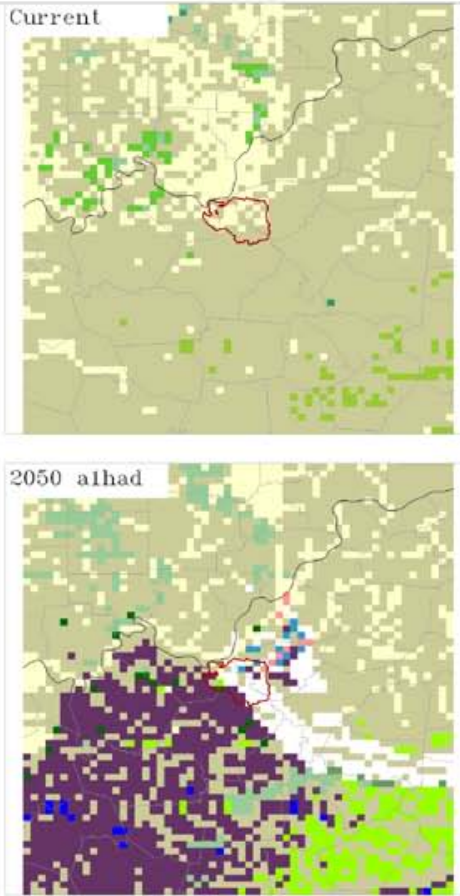

2100 athad $4 \mathrm{~h} \cdot \mathrm{r}$ $5 y+3=$ $\therefore$ of

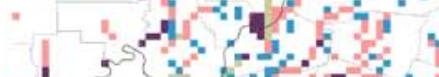
- $x y$ रु. है।

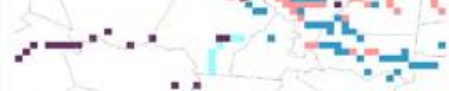

$\therefore \quad=$ 
Fort Knox

D) Different from any area in the world in 2000

-Southern Acacia-Commi phora Bushing

186) 94 -Ozarks

187) 31: -Piedmont

294) 64 t: -Araucaria Moist Forest

503) $81 \pi-$ Mid-Atlantic Coastal Plai

705) 56\% -Central Appalachian Fore

707) 30\% -Cuderlands ind Southern Ridere And Valley

12) $61 \%$-Mississippi River Alluvial Plai

715) 315 - toper East Gulf Coastal Pla

727) $82 \%$-South Atlantic Coastal Plai
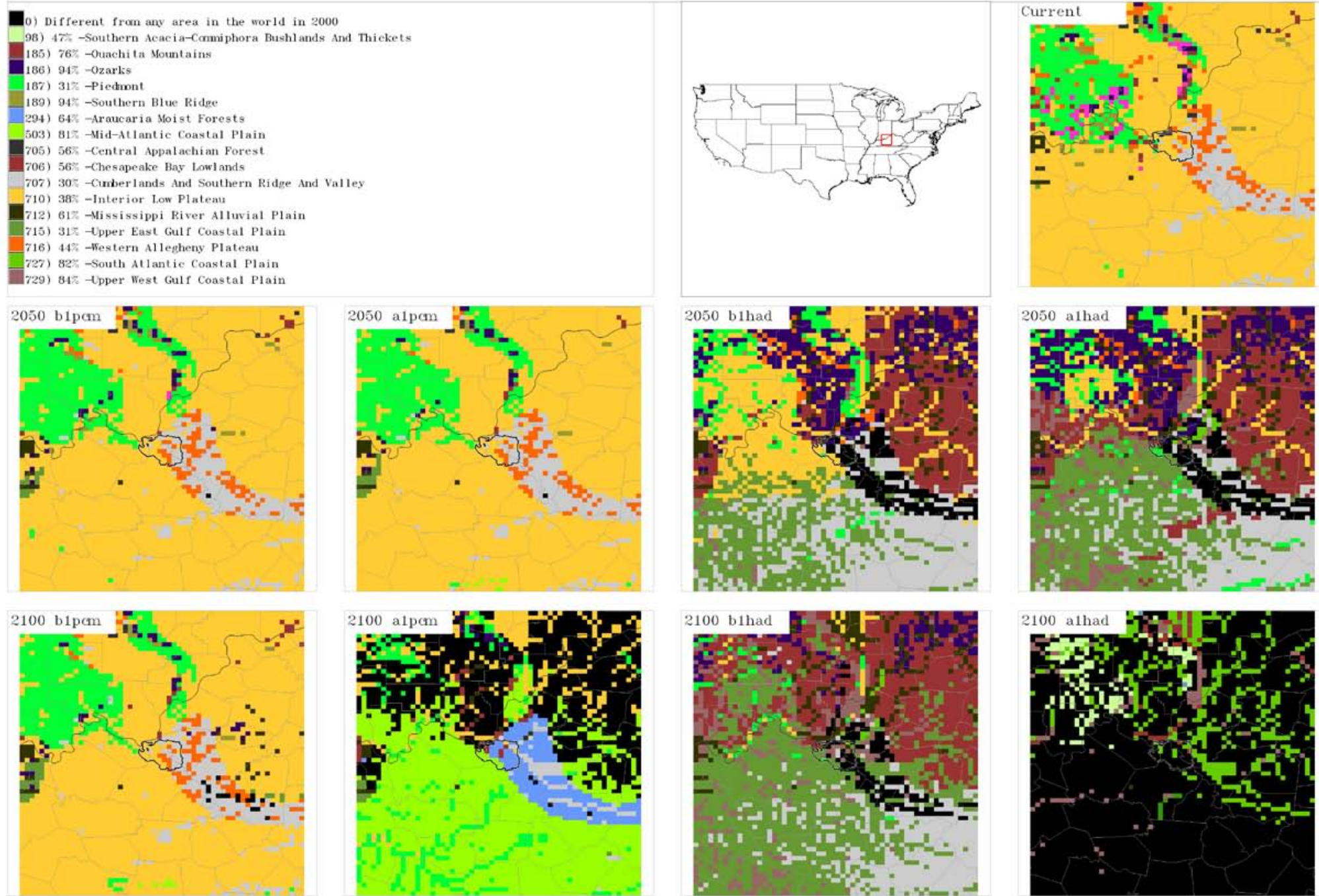


\section{Fort Knox}

These images show where the

forecasted physical and climate conditions most closely match

the conditions found across the region in 2000. This answers the question, "Where can I go today to $f$ ind the forecasted conditions for this installation?"
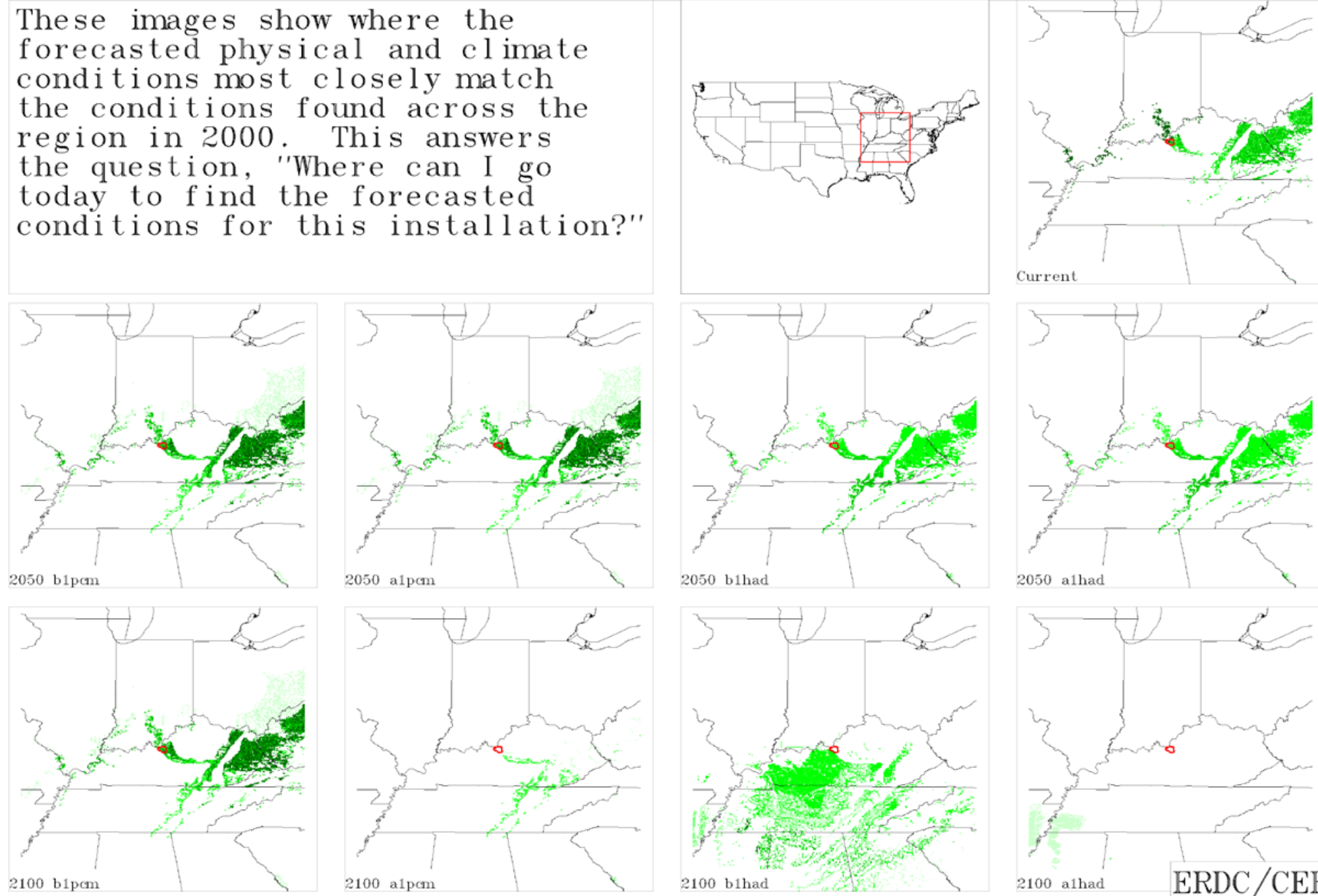

$2100 \mathrm{~b} 1 \mathrm{pcn}$

2100 a1pcn

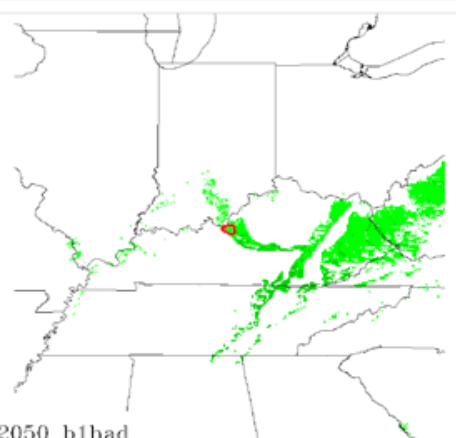

2050 b1had
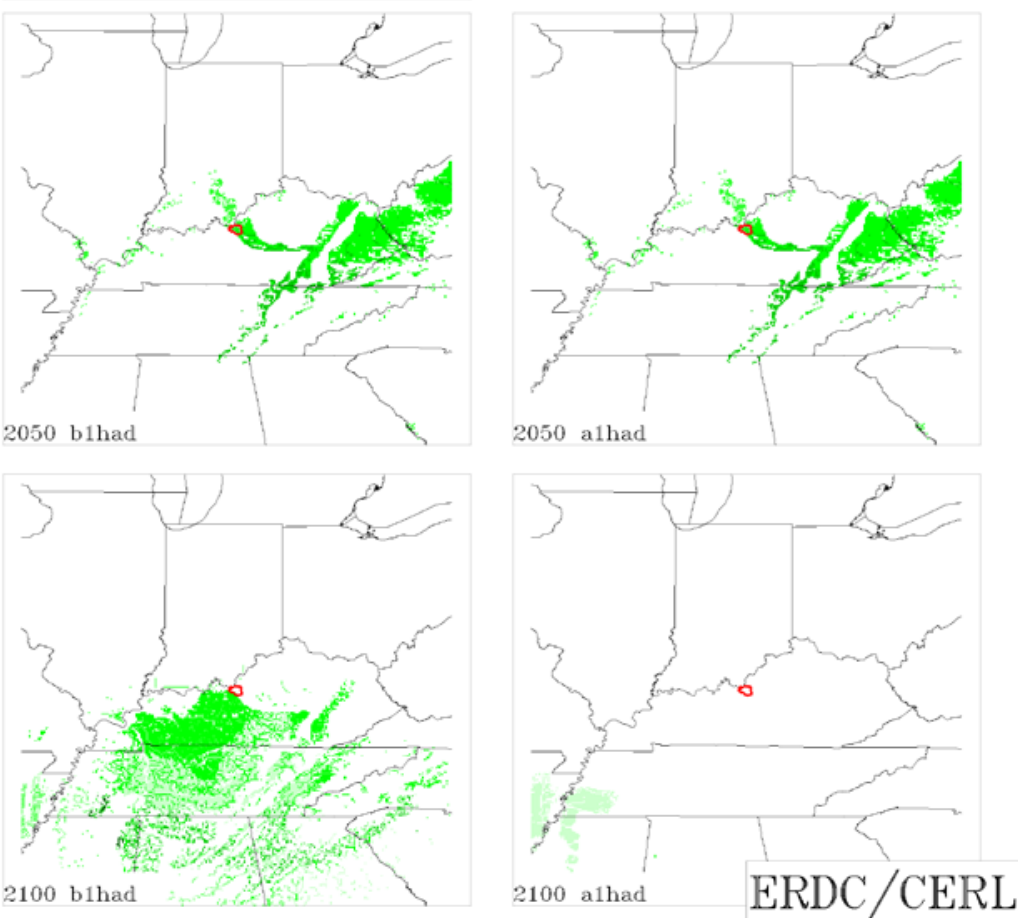

Fort Leonard Wood Military Reservation 
Fort Leonard Wood Mil itary Reservation

- o) No Current US Analog

1201) Developed, Open Space

1402) Cultivated Cropland

1403) Pasture/Hay

2102) Open Water (Fresh)

2103) Open Water (Brackish/Salt)

4115) Ozark-Ouachita Dry-Mesic Oak Forest

4118) Crosstimbers Oak Forest and Noodland

4207) Ozark-Ouachi ta Mesic Hardwood Forest

4328) Ozark-Ouachita Shortleaf Pine-Oak Forest and Woodl and

1332) West Gulf Coastal Plain Pine-Hardwood Forest

8202) Evergreen Plantations or Managed Pine (can include dense successi

8408) Modified/Managed Southern Tall Grassland
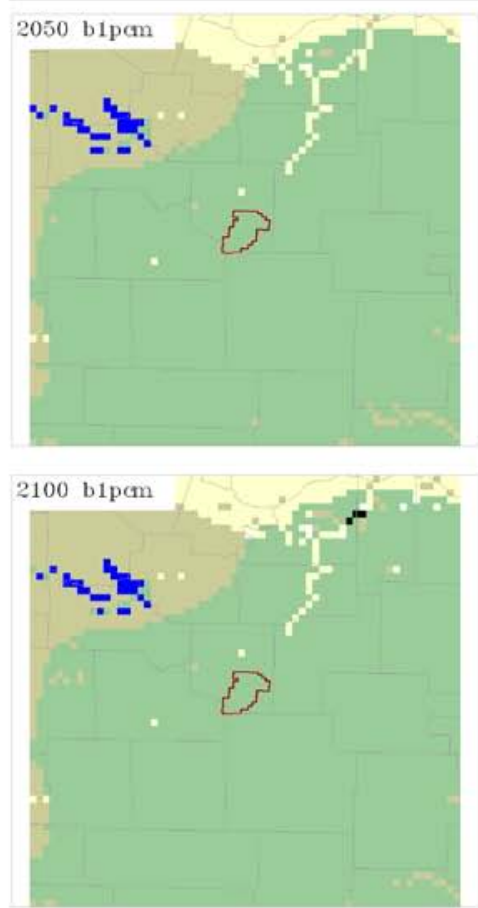
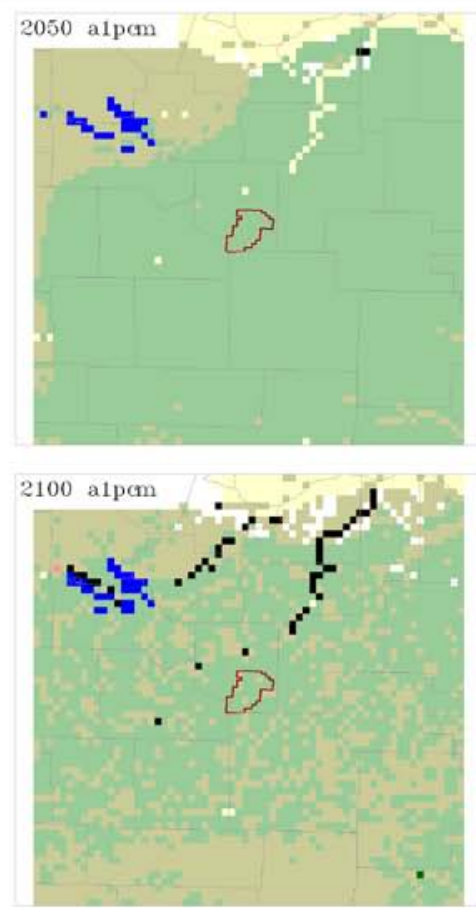
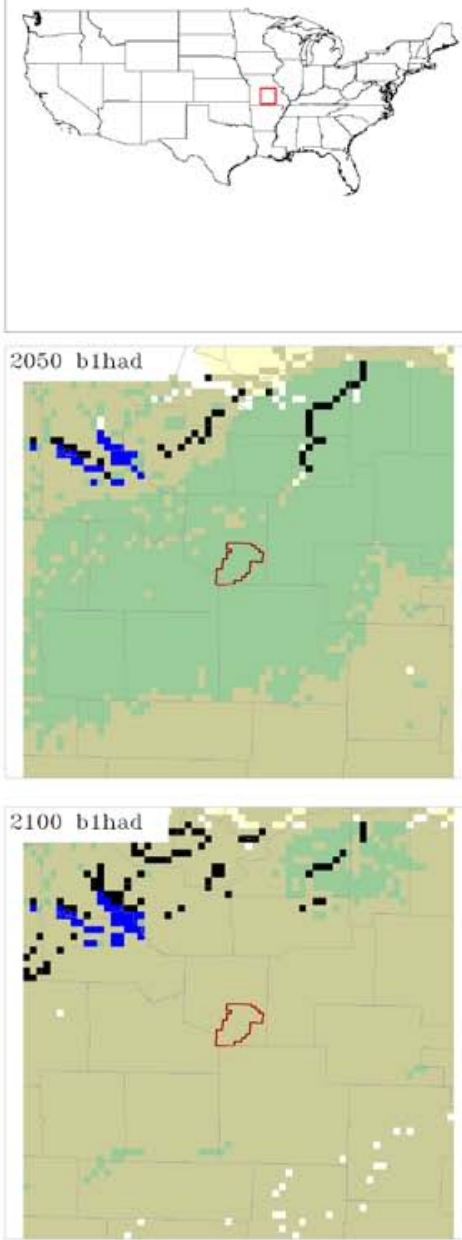
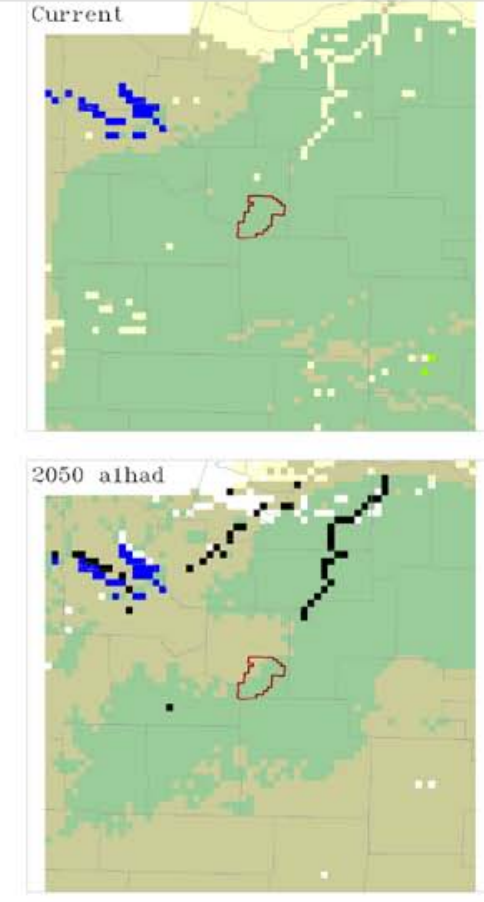

2100 alhad $-3=-y^{2}+y^{2}$

$x=$

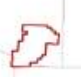


Fort Leonard Wood Military Reservation

0) Different from any area in the world in 2000
50) 3 T - Albertine Rift Nontane Forests

50) $3 \%$-Albertine Rift Nontane Fores

183) $61 \%$-North Central Tillplain

185) $76 \%$-Ouachi to Mountains

186) $94 \%$-Ozarks
187) $31 \%$-Piedwo

427) $44 \pi$-Dry Chaco

431) $70 \%$ - Truguayan Savanna
441) $78 \%$-Paran Flooded Savann

-41) $78 \%$ - Paran Fat $78 \%$-Great Lakes

710) 38: -Interior Low Platen

-751) 72\%, -Croset talterass Trairie Tallgrass Prair

757) $90 \%$-Osage Plains/Flint Hills Prair
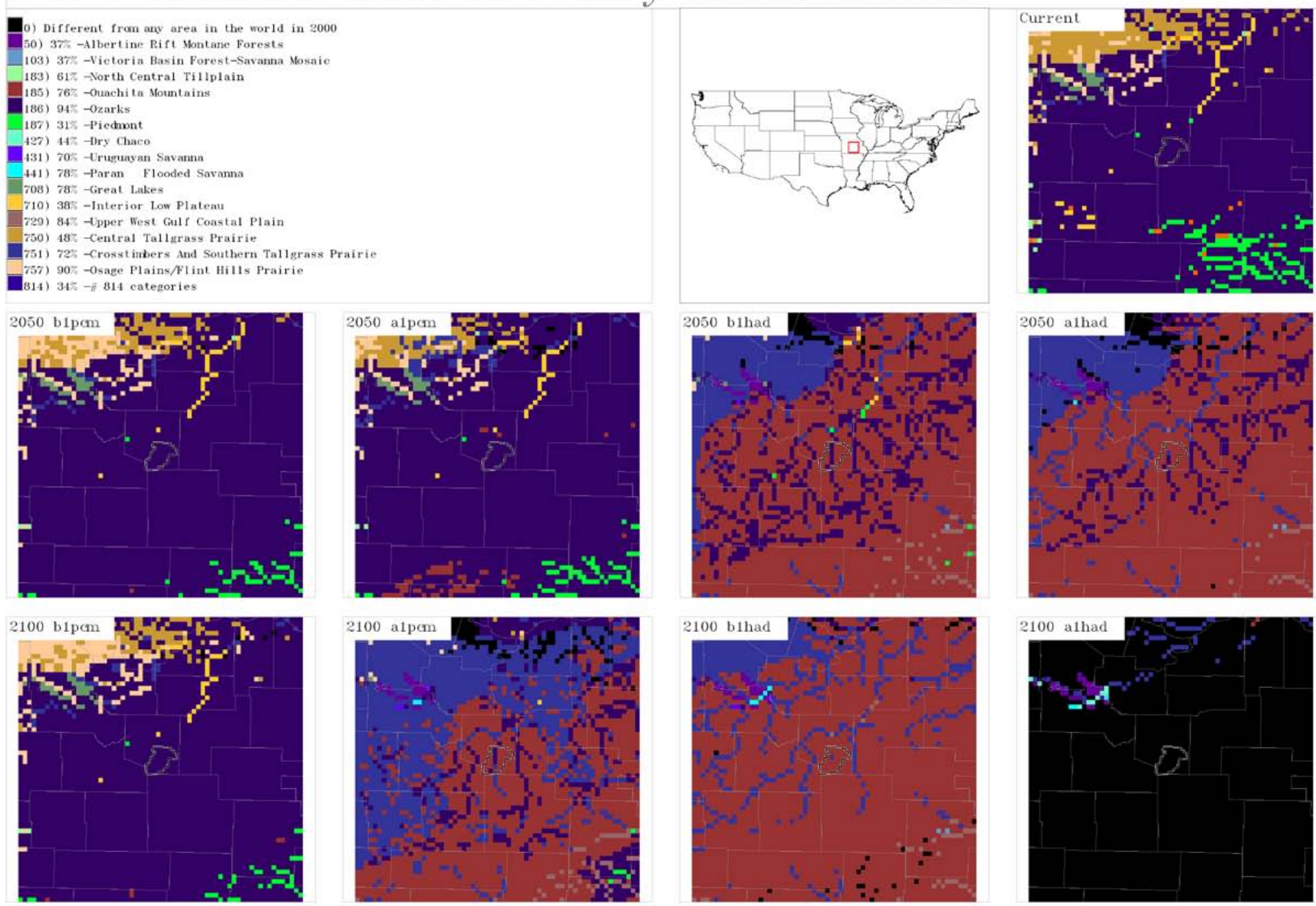
Fort Leonard Wood Military Reservation These images show where the forecasted physical and climate conditions most closely match the conditions found across the region in 2000. This answers the question, "Where can I go today to find the forecasted conditions for this installation?"
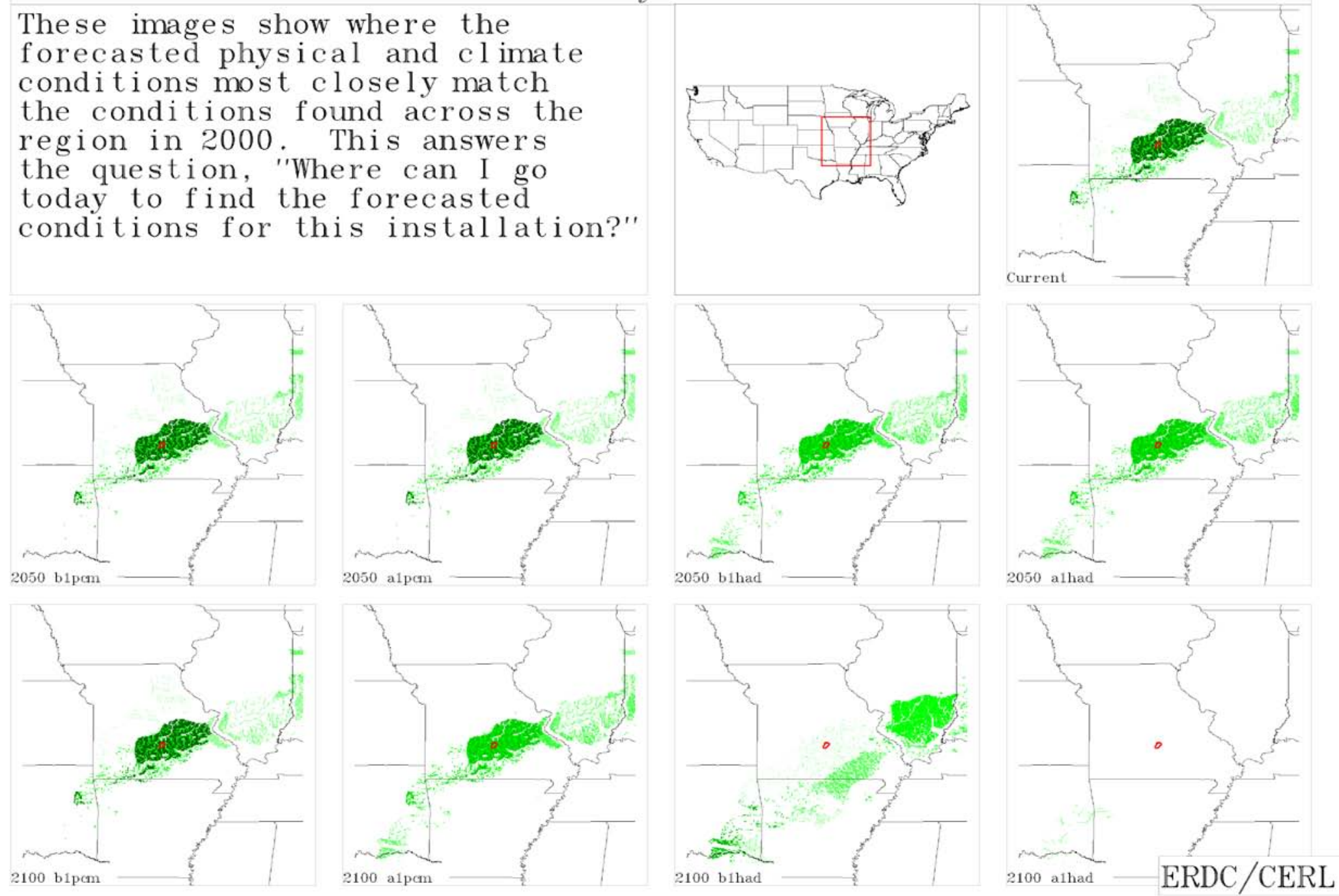

Fort Lewis Wood Military Reservation 
Fort Lewis Military Reservation
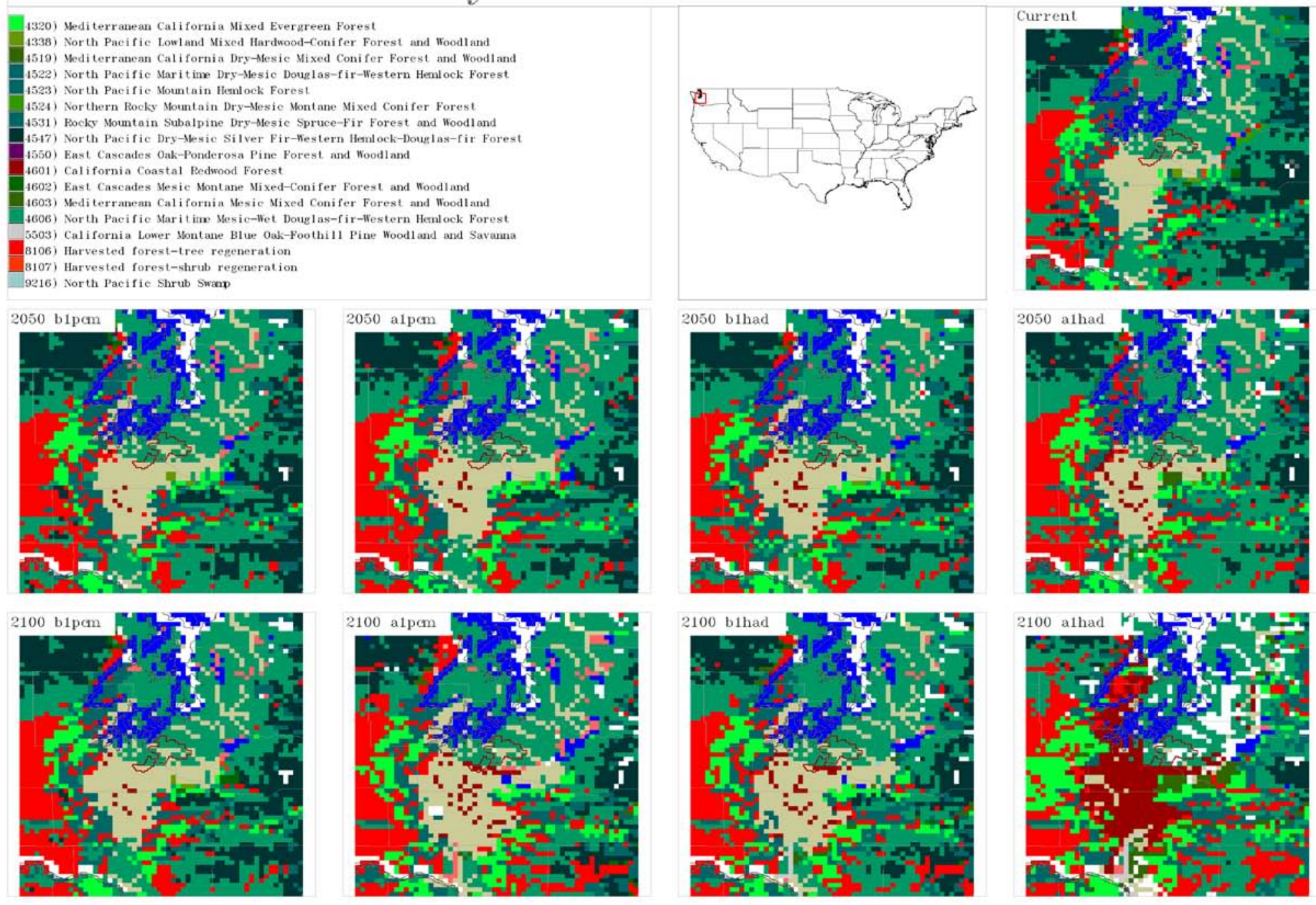
Fort Lewis Military Reservation

Din) 92; -Valdivian Temperate Forests

-435) 57\% - Patagonian Steppe

188) 427 -Southrest Iberian Mediterranean Sclerophyllous And Mixed Forests

488) $42 \%$-Southrest Iberian Med
496) $38 \%$-Cal i fornia North Coag

498) 57. - East Cascades - Modoc Plateau

502) $33 \%$-Klamth Mountains
533) $71 \pi$-Cantabrian Mixed Fores

536) 64 , -Celtic Broadleaf Forests

664) $76 \%-$ IIlyrian Deciduous Forests
$670)$ 45\% - - Jor thwest Iberian Mont ane Forest s

717) $66 \%$ - Teaperate Broadleaf And Mixed Forests

722) $71 \%$ - Tor th Cascade

732) 515 - Hest Cascades

-734) $81 \%$ - Temperate Conifor Forests

Torests
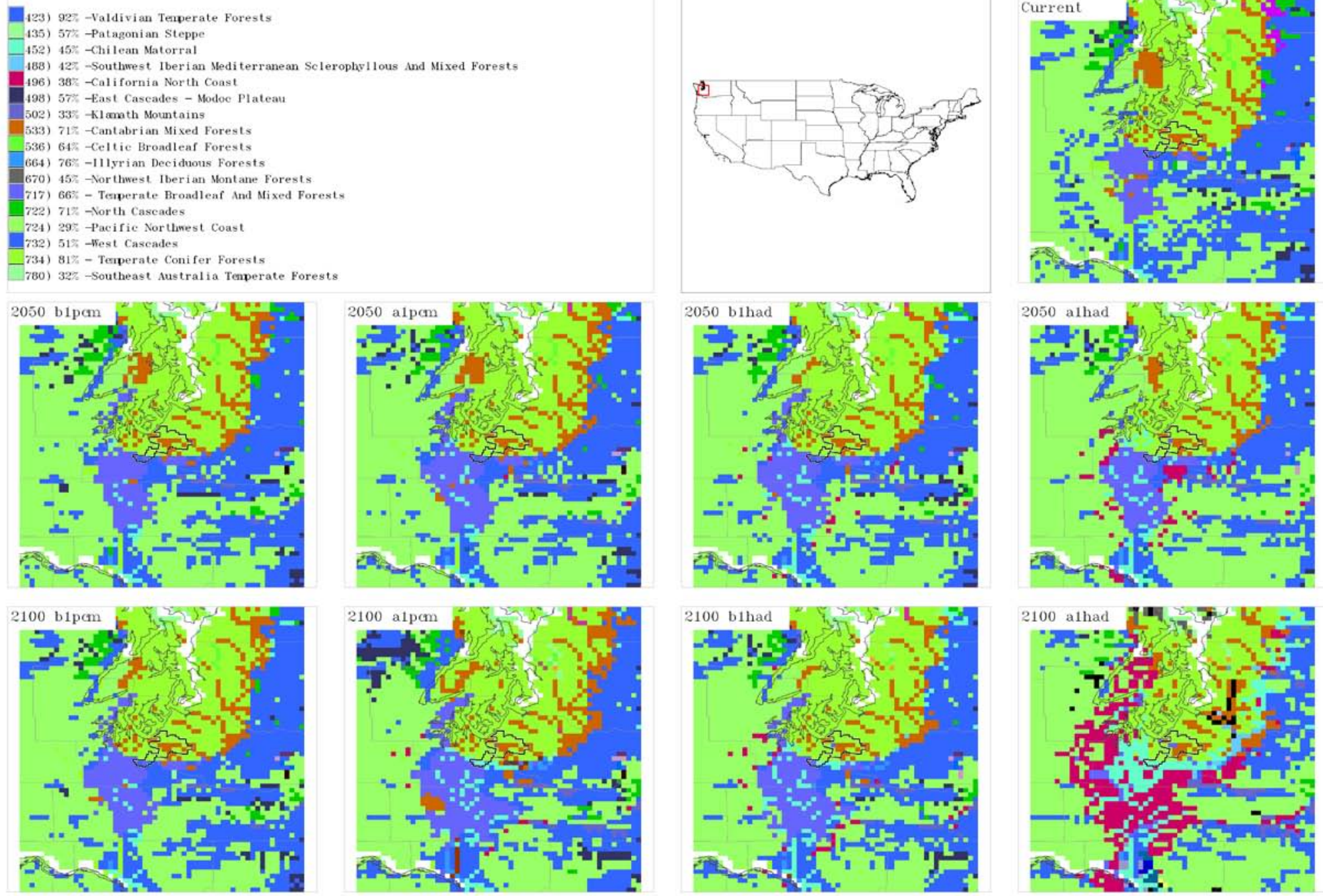
Fort Lewis Military Reservation

These images show where the

forecasted physical and climate conditions most closely match

the conditions found across the region in 2000. This answers the question, "Where can I go today to $f$ ind the forecasted conditions for this installation?"
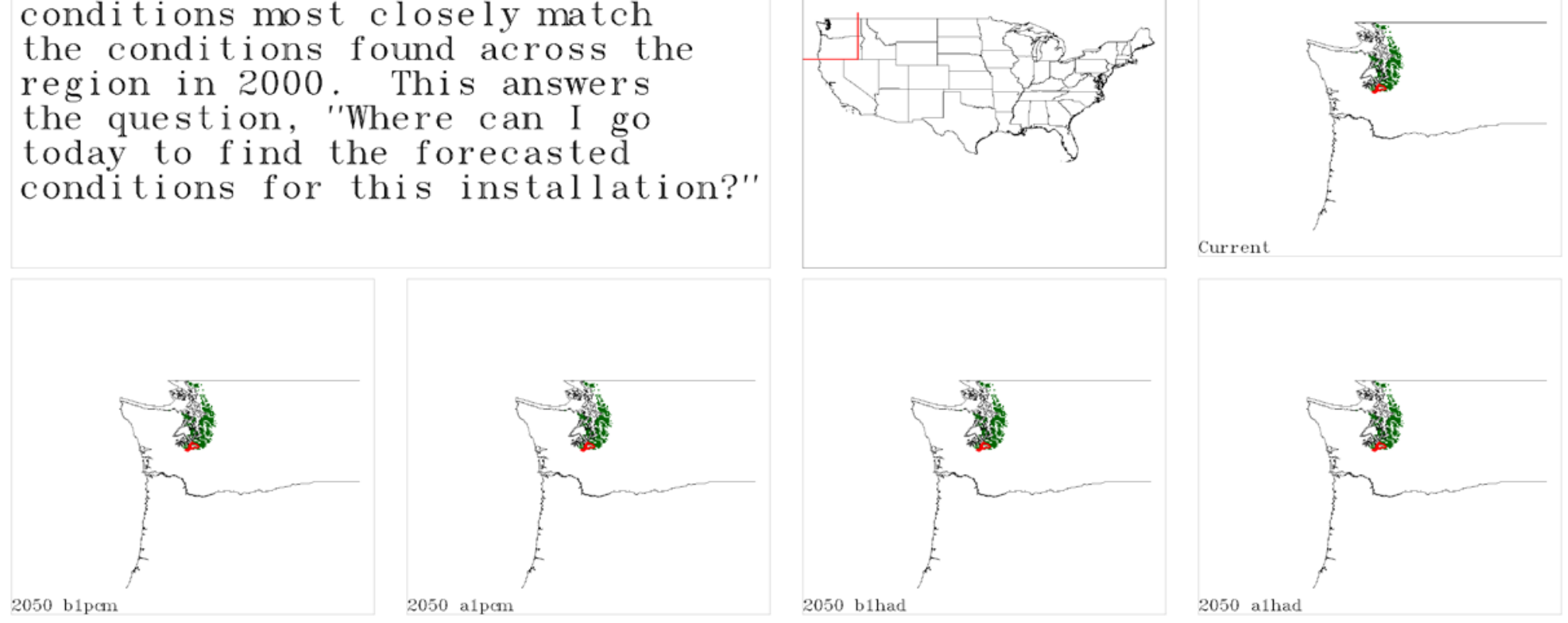

2050 b1had
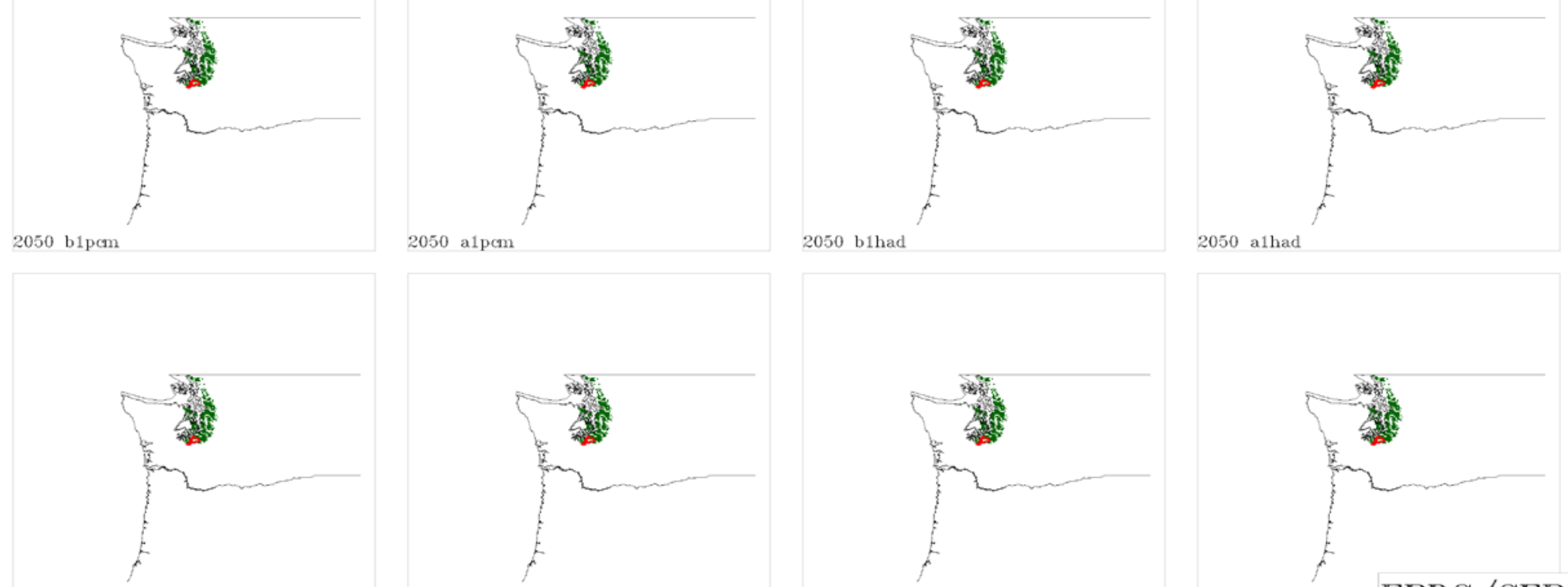

$2100 \mathrm{~b} 1 \mathrm{pcm}$
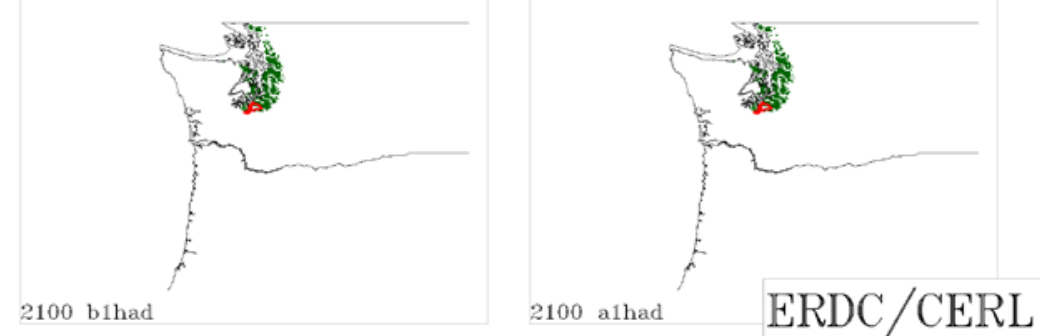

Fort McCoy 


\section{Fort McCoy}

0) No Current US Analog

1402) Cul tivated Cropl and

1403) Pasture/Hay

2102) Open Water (Fresh)

4113) Laurentian-Acadian Nor thern Hardwoods

4115) Ozark-Ouachita Dry-Mesic Oak Forest

4118) Crosstimbers Oak Forest and Woodland

8408) Modified/Managed Southern Tall Grass]
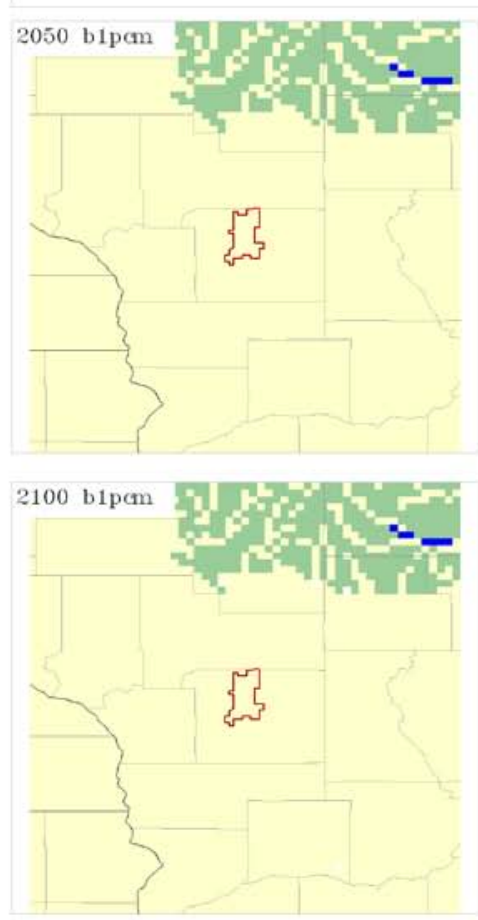
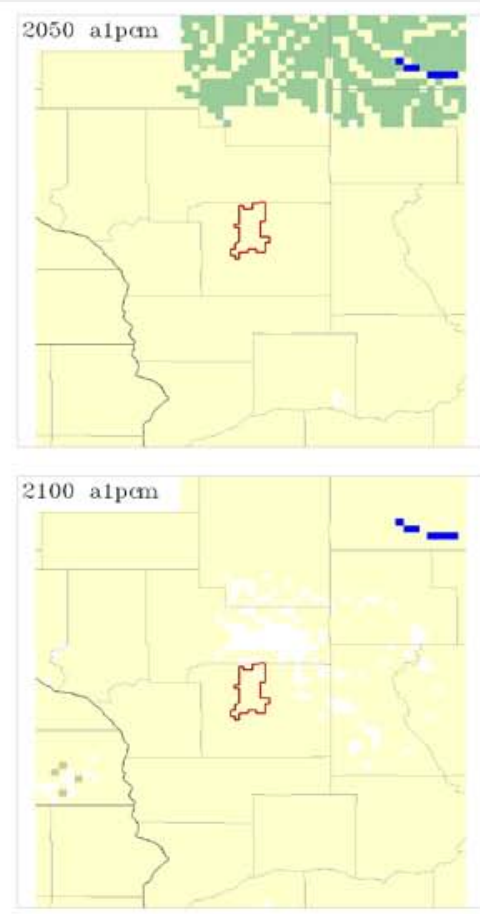
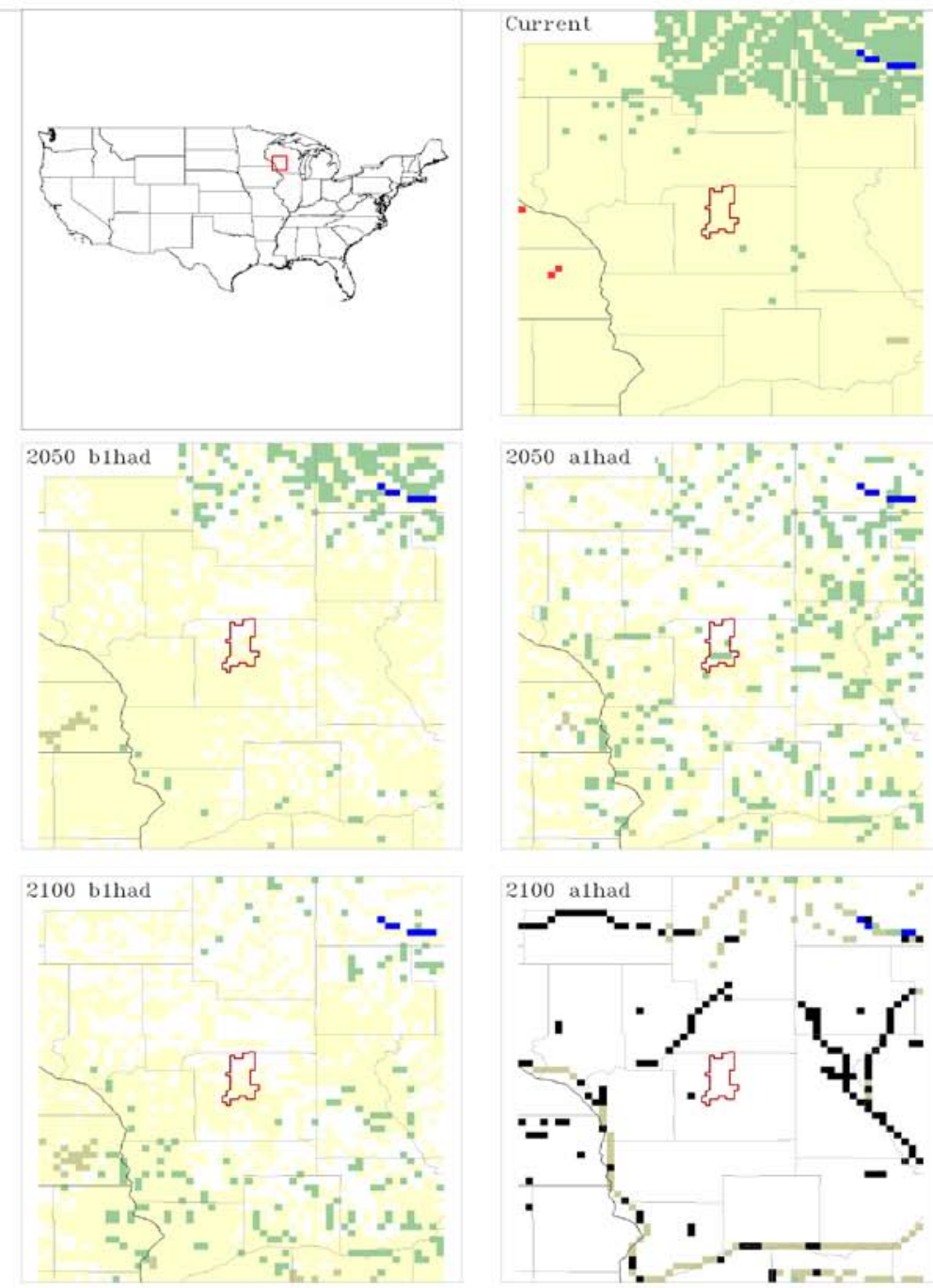
0) Different from any area in the world in 2000

186) $94 \%-0$ zarks

188) 53\% -Prairie-Forest Border

433) $36 \%$-Humid Pampas

708) $78 \%$-Great Lakes

714) $99 \%$-Superior Mixed Forest

750) 48\% -Central Tallgrass Prairie

$751) 72 \%$-Crosstimbers And Southern Tallgrass Prairie

756) $74 \%$-Nor thern Tallgrass Prairie

757) 90\% -Osage Plains/Flint Hills Prairie
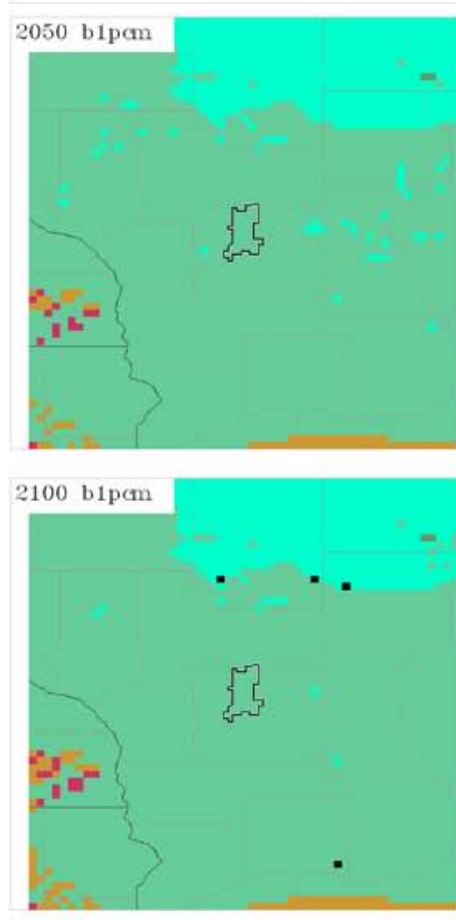
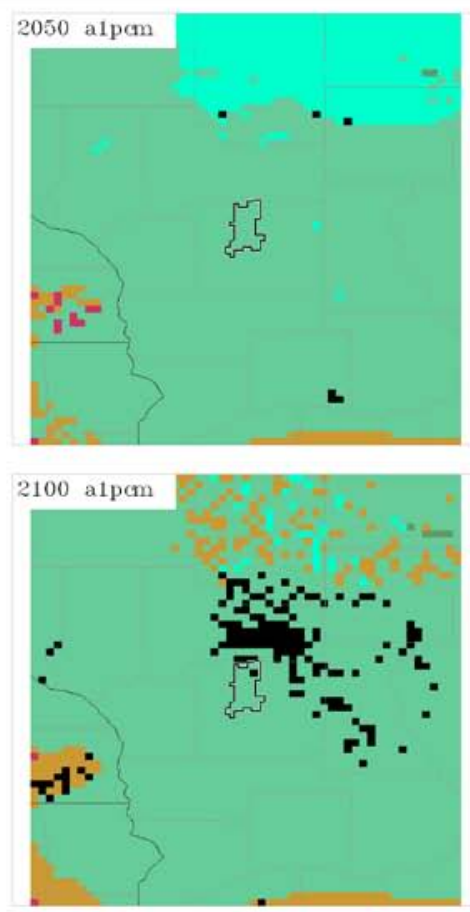
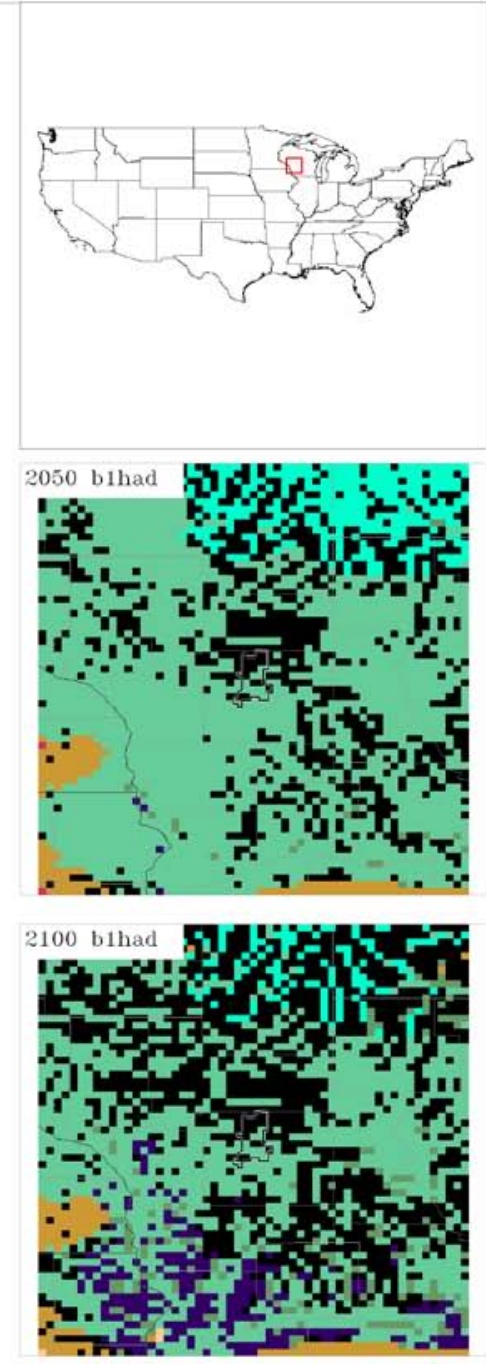
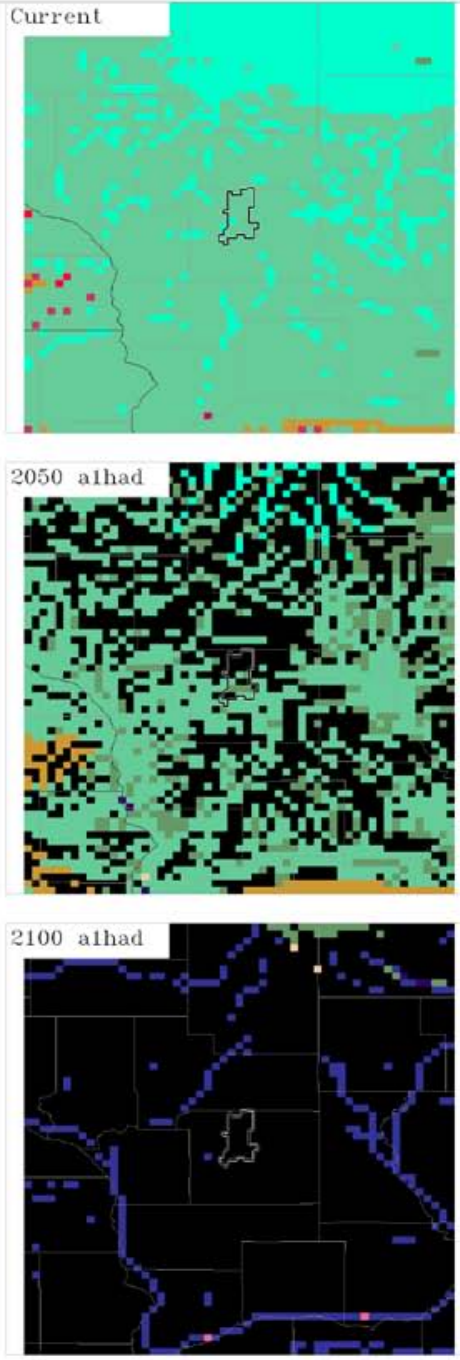


\section{Fort McCoy}

These images show where the forecasted physical and climate conditions most closely match the conditions found across the region in 2000. This answers the question, "Where can I go today to find the forecasted conditions for this installation?"
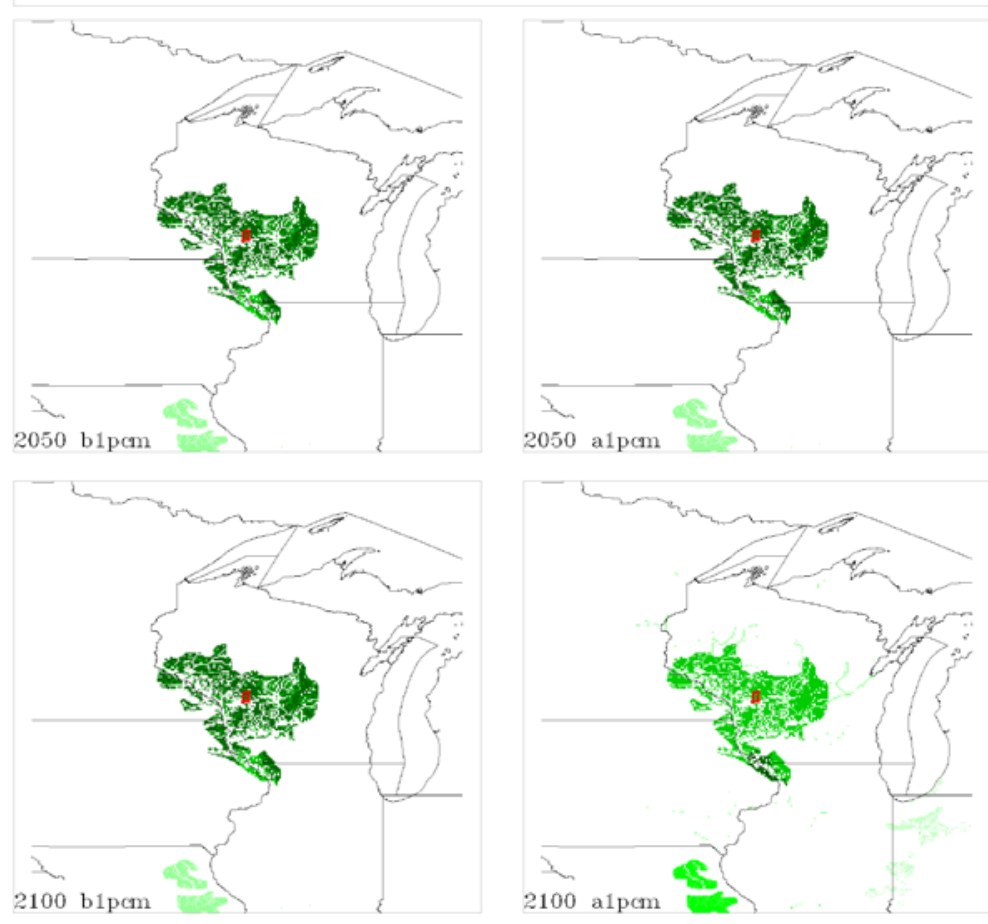
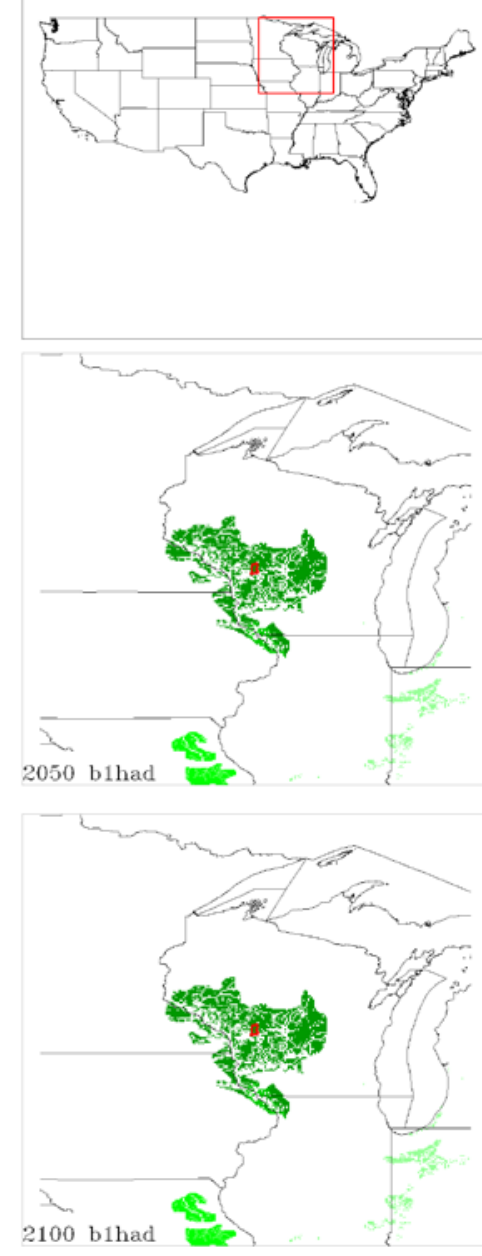

Fort Polk Military Reservation
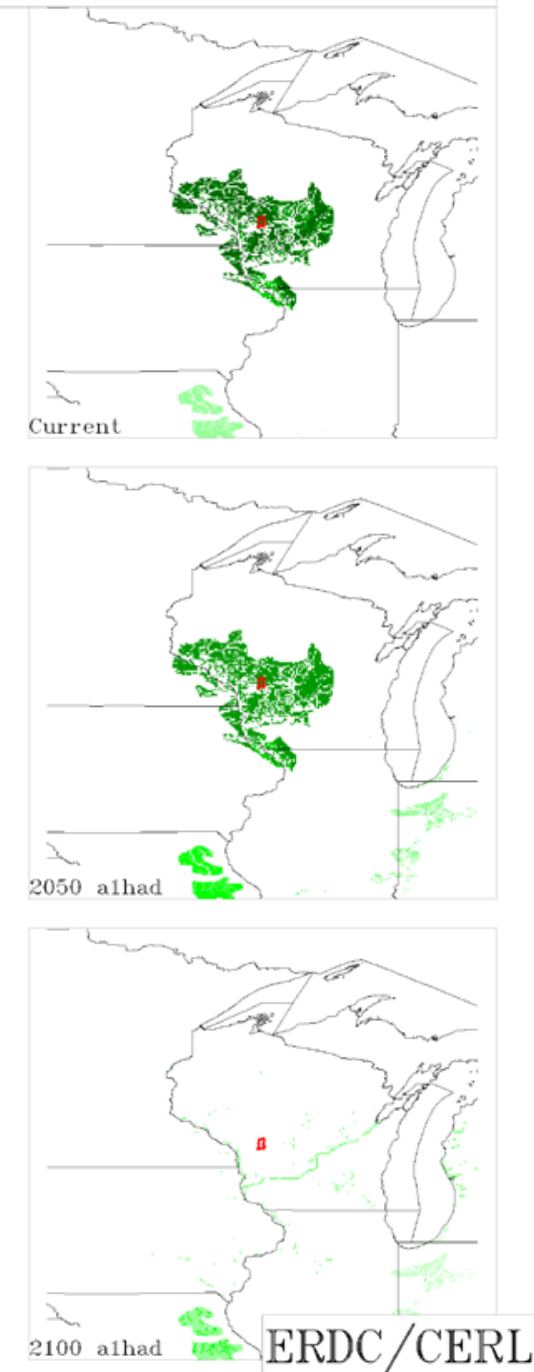
Fort Polk Military Reservation

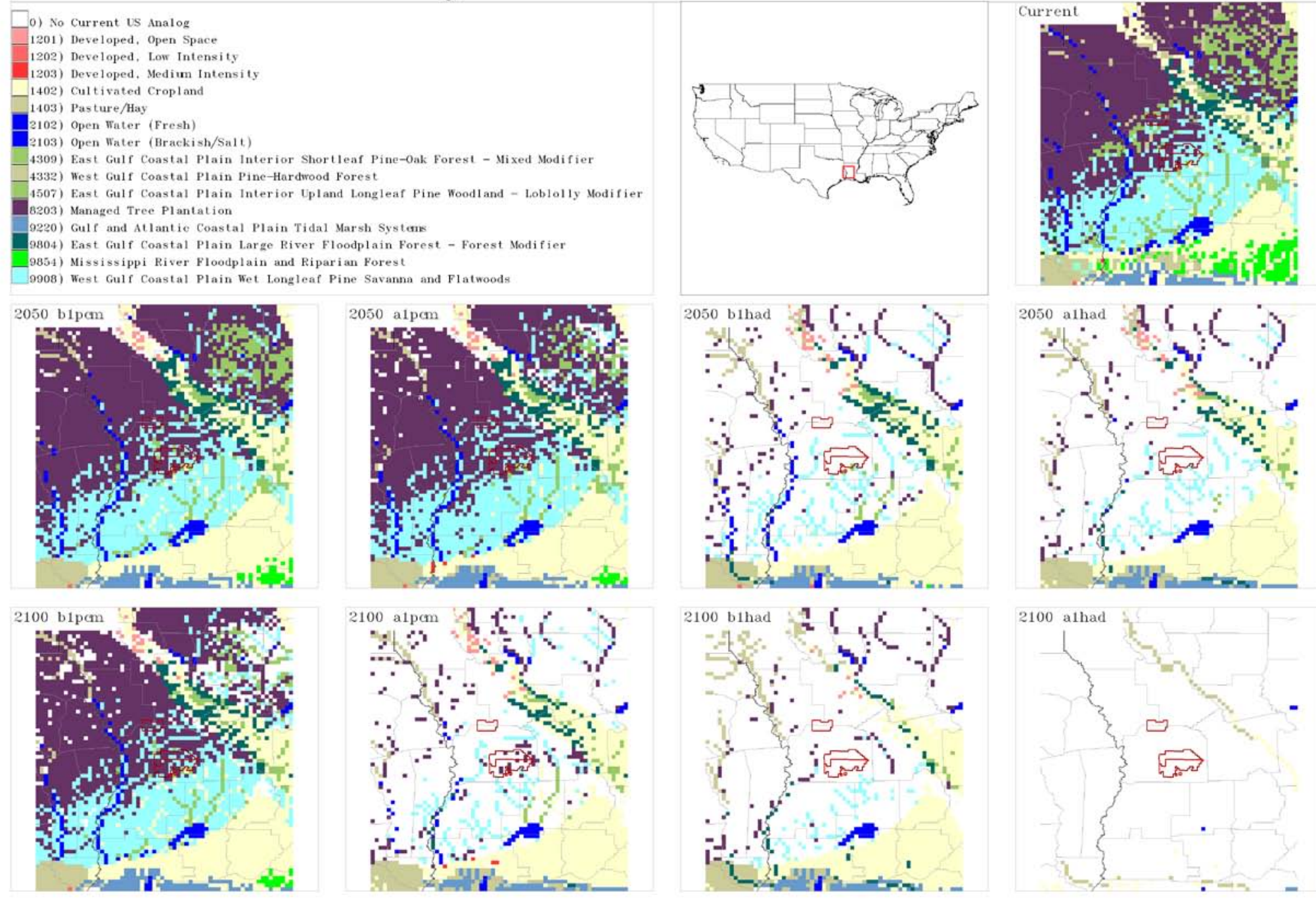


Fort Polk Military Reservation
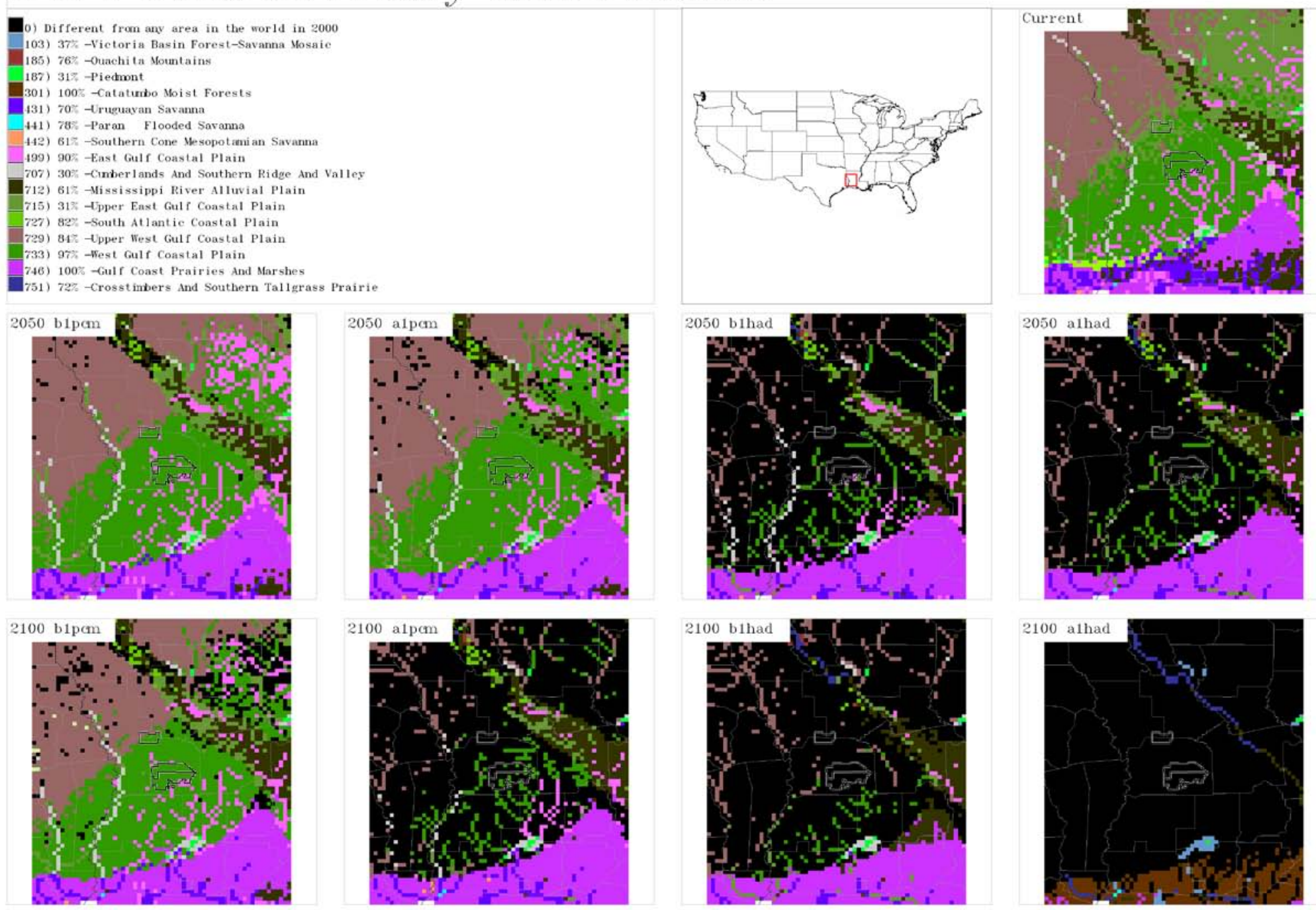
Fort Polk Military Reservation

These images show where the

forecasted physical and climate conditions most closely match

the conditions found across the region in 2000. This answers the question, "Where can I go today to find the forecasted conditions for this installation?"
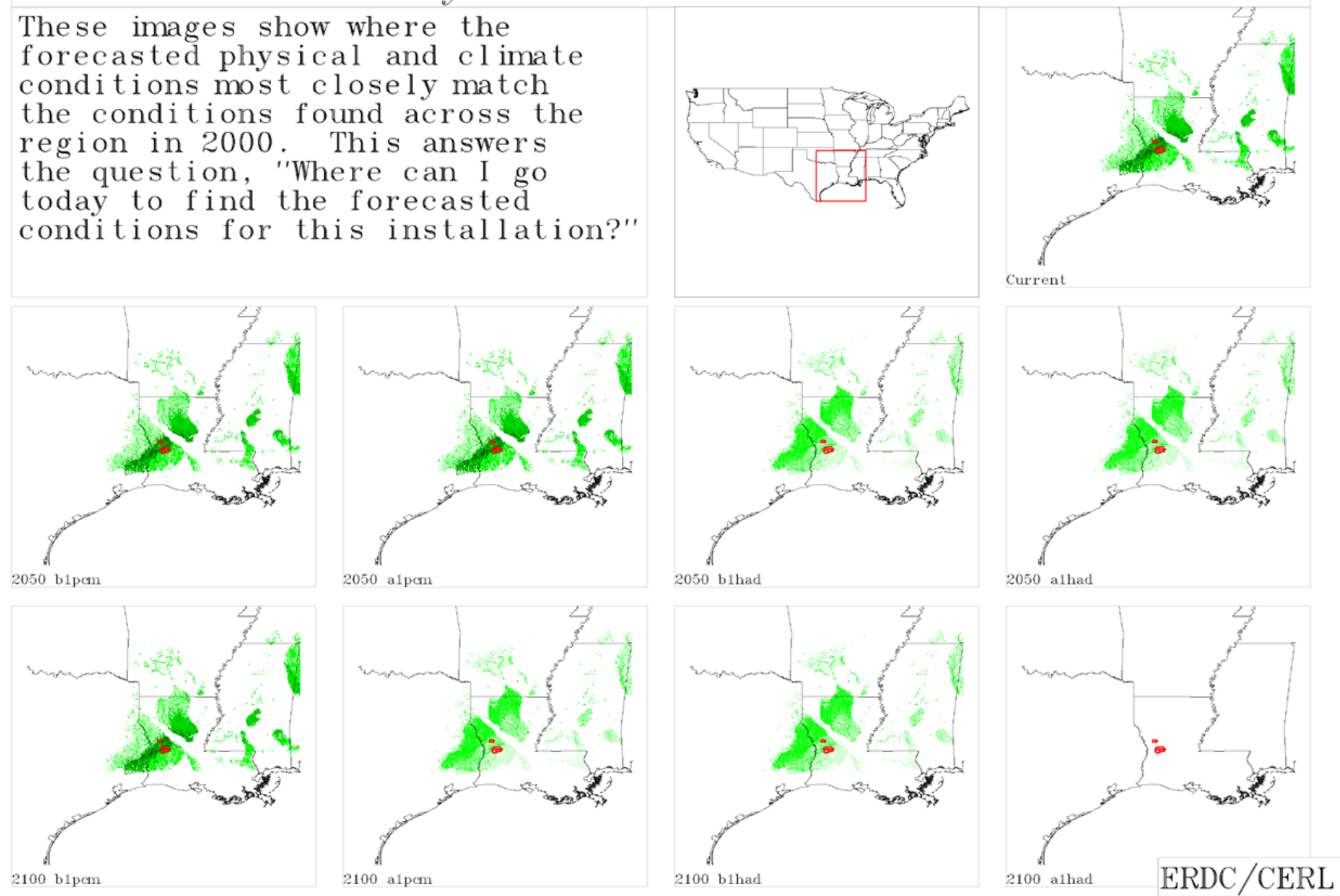

Fort Riley Military Reservation 


\section{Fort Riley Military Reservation}

0) No Current US Analog

1402) Cultivated Cropland

1403) Pasture/Hay

4152) Edwards Plateau Limestone Savanna anc

5810) Western Great Plains Mesquite Woodlar 7302) Central Mixedgrass Prairie

7317) Southeastern Great Plains Tallgrass I

8408) Modified/Managed Southern Tall Grass]

$2050 \mathrm{~b} 1 \mathrm{pcm}$

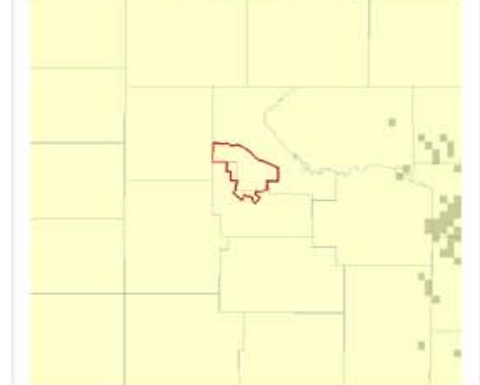

$2100 \mathrm{~b} 1 \mathrm{pcm}$

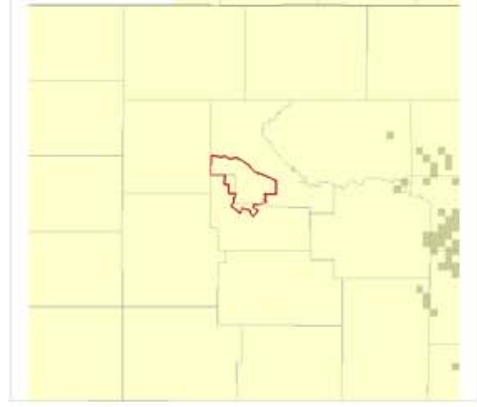

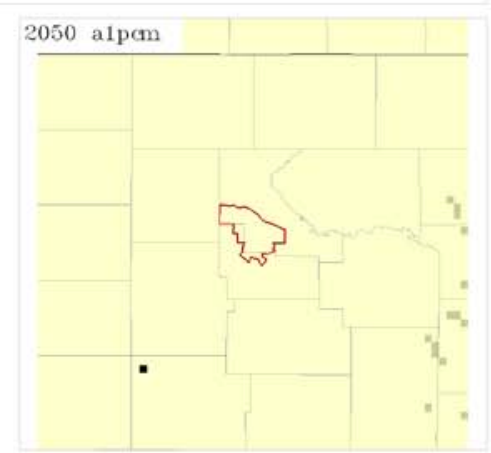

2100 alpcm

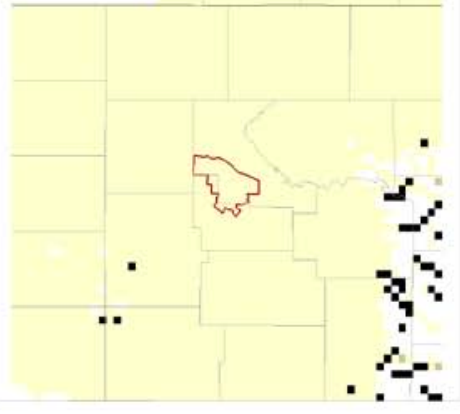

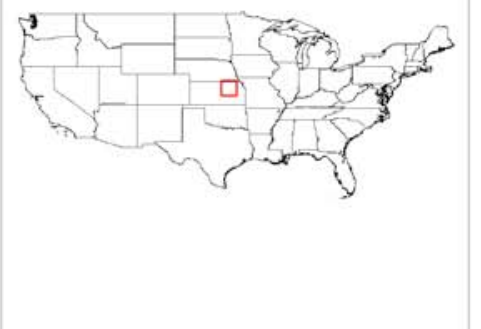

2050 blhad

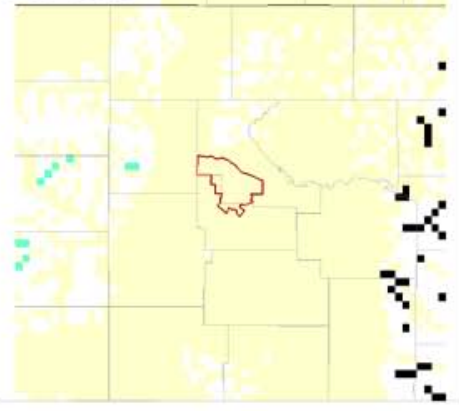

$$
2100 \text { b1had }
$$

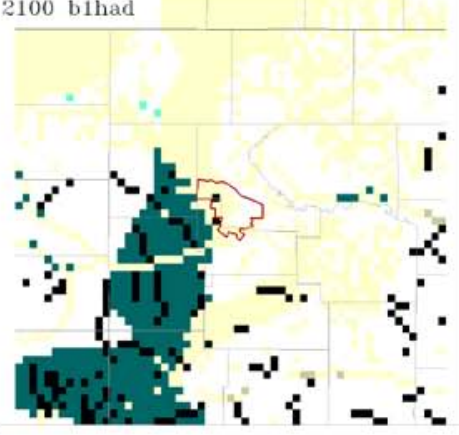

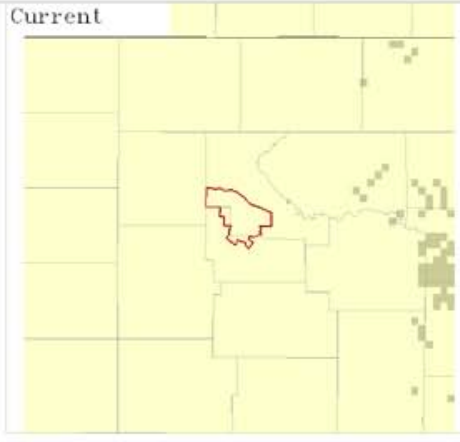

2050 alhad
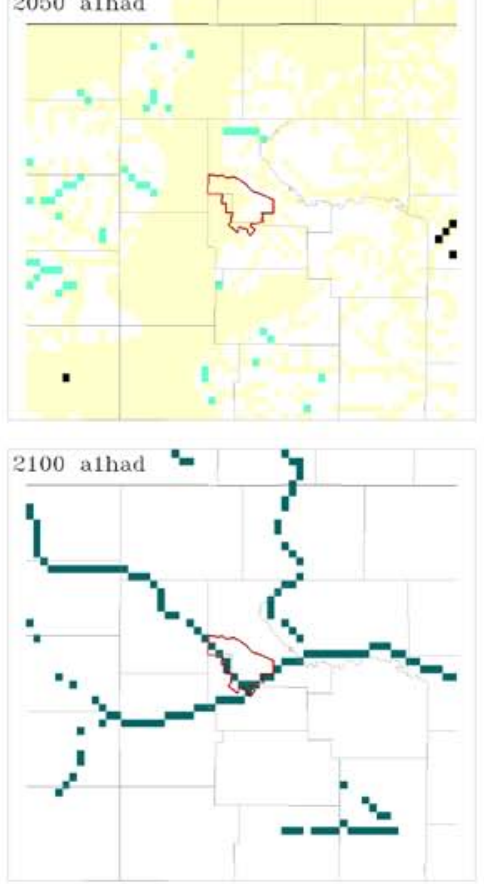
Fort Riley Military Reservation

0) Different from any area in the world in

269) 54\% -Southern Shortgrass Prairie

433) $36 \%$-Humid Pampas

748) $86 \%$-Central Mixed-Grass Prairie

750) $48 \%$-Central Tallgrass Prairie

751) $72 \%$-Crosstimbers And Southern Tallgre

753) $53 \%$-Edwards Plateau

75\%) $90 \%$-Osage Plains/Flint Hills Prairie
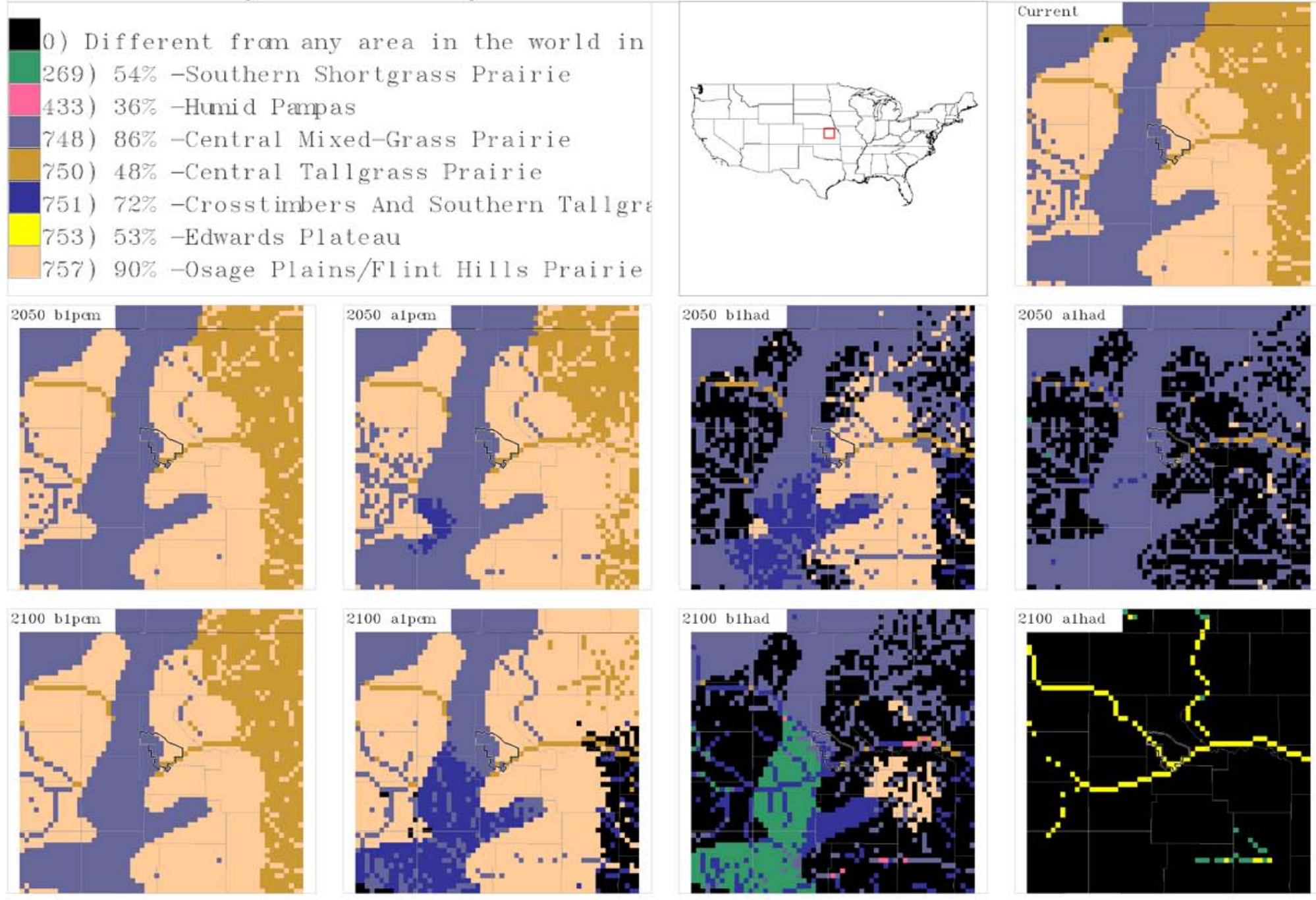
Fort Riley Military Reservation

These images show where the

forecasted physical and climate conditions most closely match

the conditions found across the region in 2000. This answers the question, "Where can I go today to $f$ ind the forecasted conditions for this installation?"
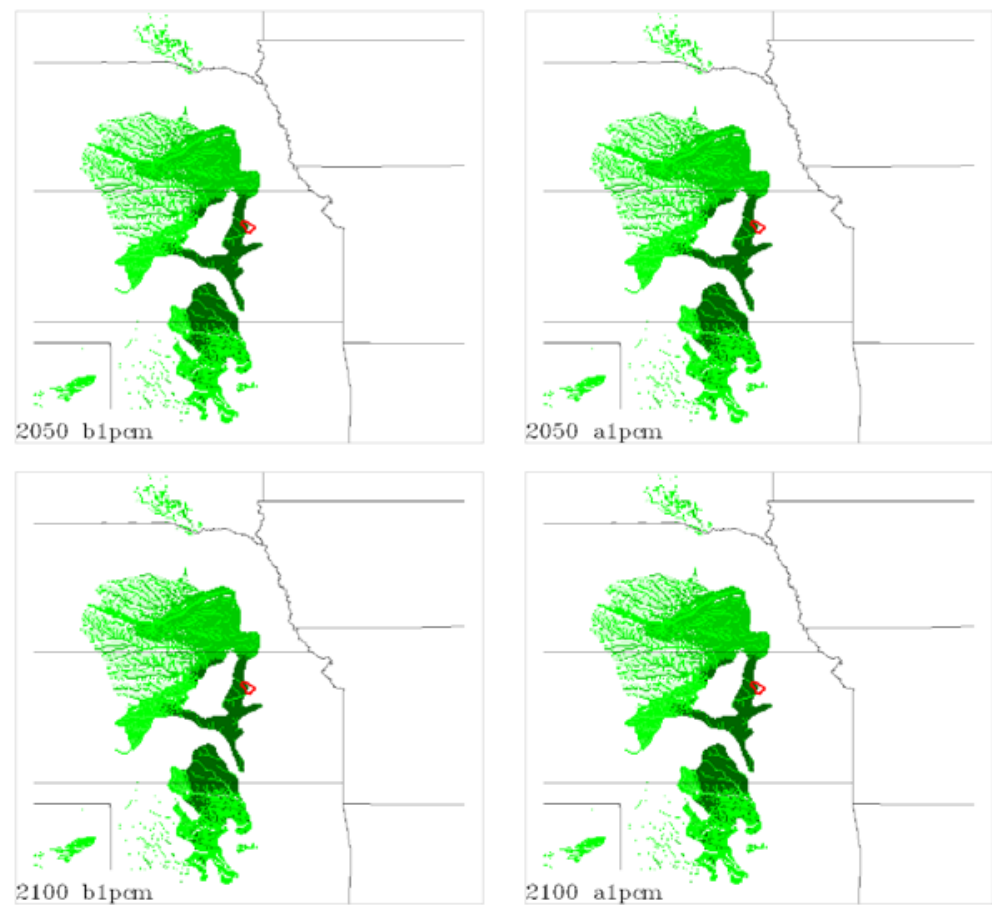
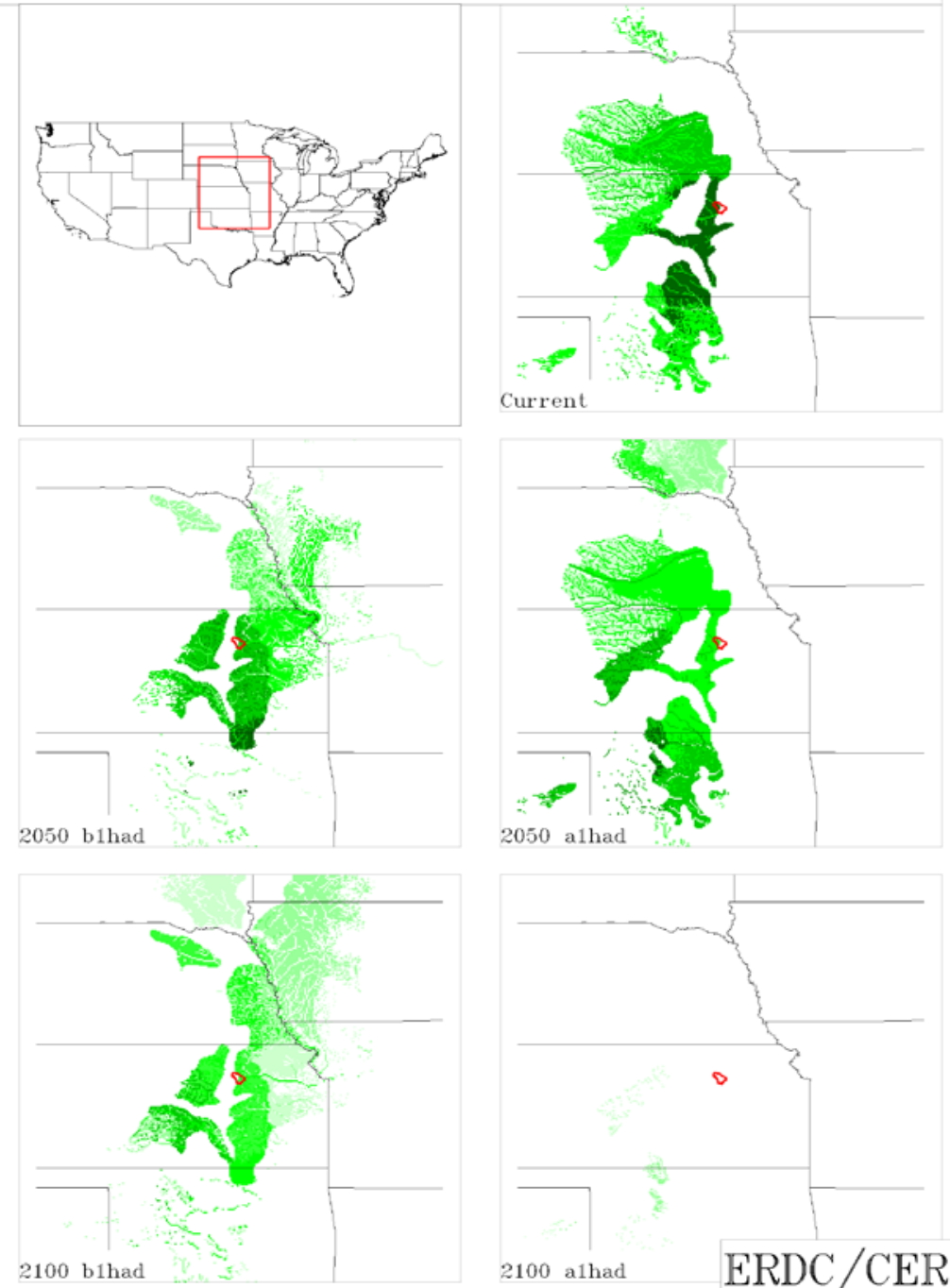
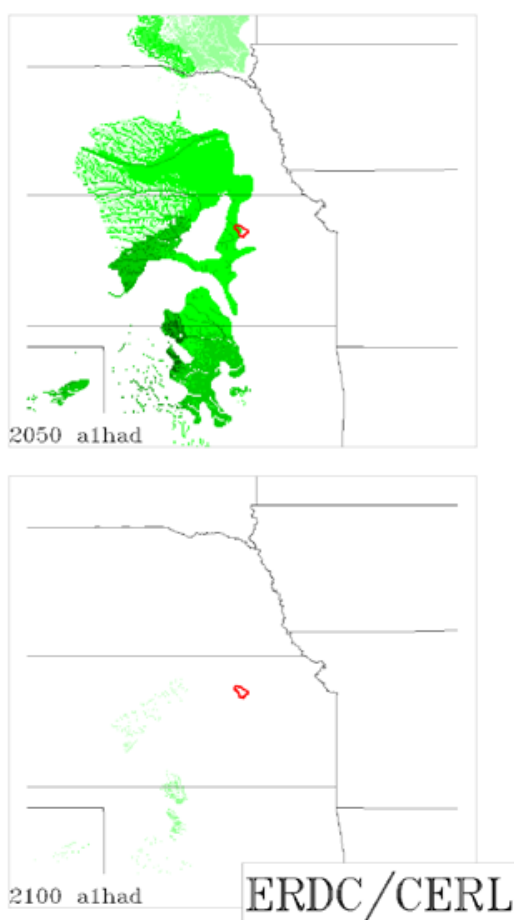

Fort Rucker Military Reservation 
Fort Rucker Military Reservation

$\square$ 0) No Current US Analog
1402) Cultivated Cropland
1403) Pasture/Hay
2102) Open Water (Fresh)
4501) East Gulf Coastal Plain Interior Upland Longleaf Pine Woo
4507) East Gulf Coastal Plain Interior Upland Longleaf Pine Woo
4508) East Gulf Coastal Plain Interior Upland Longleaf Pine Woo
8202) Evergreen Plantations or Managed Pine (can include dense :
8203) Managed Tree Plantation
9804) East Gulf Coastal Plain Large River Floodplain Forest - F.
9903) East Gulf Coastal Plain Near-Coast Pine Flatwoods - Open I
9908) West Gulf Coastal Plain Wet Longleaf Pine Savanna and Fla
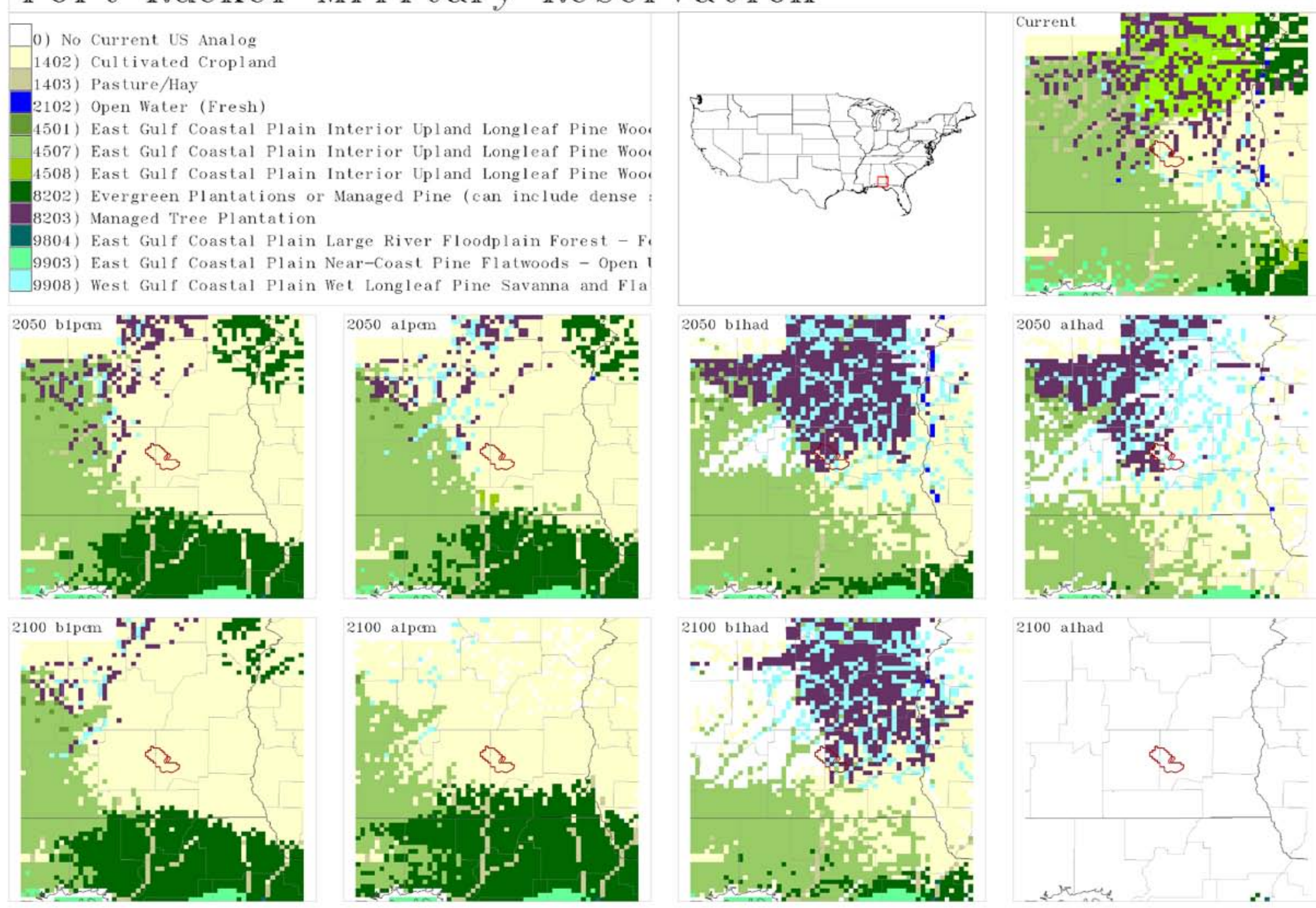
Fort Rucker Military Reservation

0) Different from any area in the world in 2000

48) 47\% -Southern Acacia-Comi phora Bushlands And Thickets

293) $71 \%$-Al to Paran Atlantic Forests

294) $64 \%$-Araucar ia Moist Forests

301) $100 \%$-Catatumo Moist Fores

499) $90 \%$-East Gulf Coastal Plai

503) $81 \%$-Mid-Atlantic Coastal Plain

207 -Cumberlands And Southern Ridge And Yalley

712) $61 \%$-Mississippi River Alluvial Plain

715) $31 \%$-Upper East Gulf Coastal Plain

727) $82 \%$-South Atlantic Coastal Plain

729) $84 \%$-Upper West Gulf Coastal Pran

733) $97 \%$-West Gulf Coastal Plain
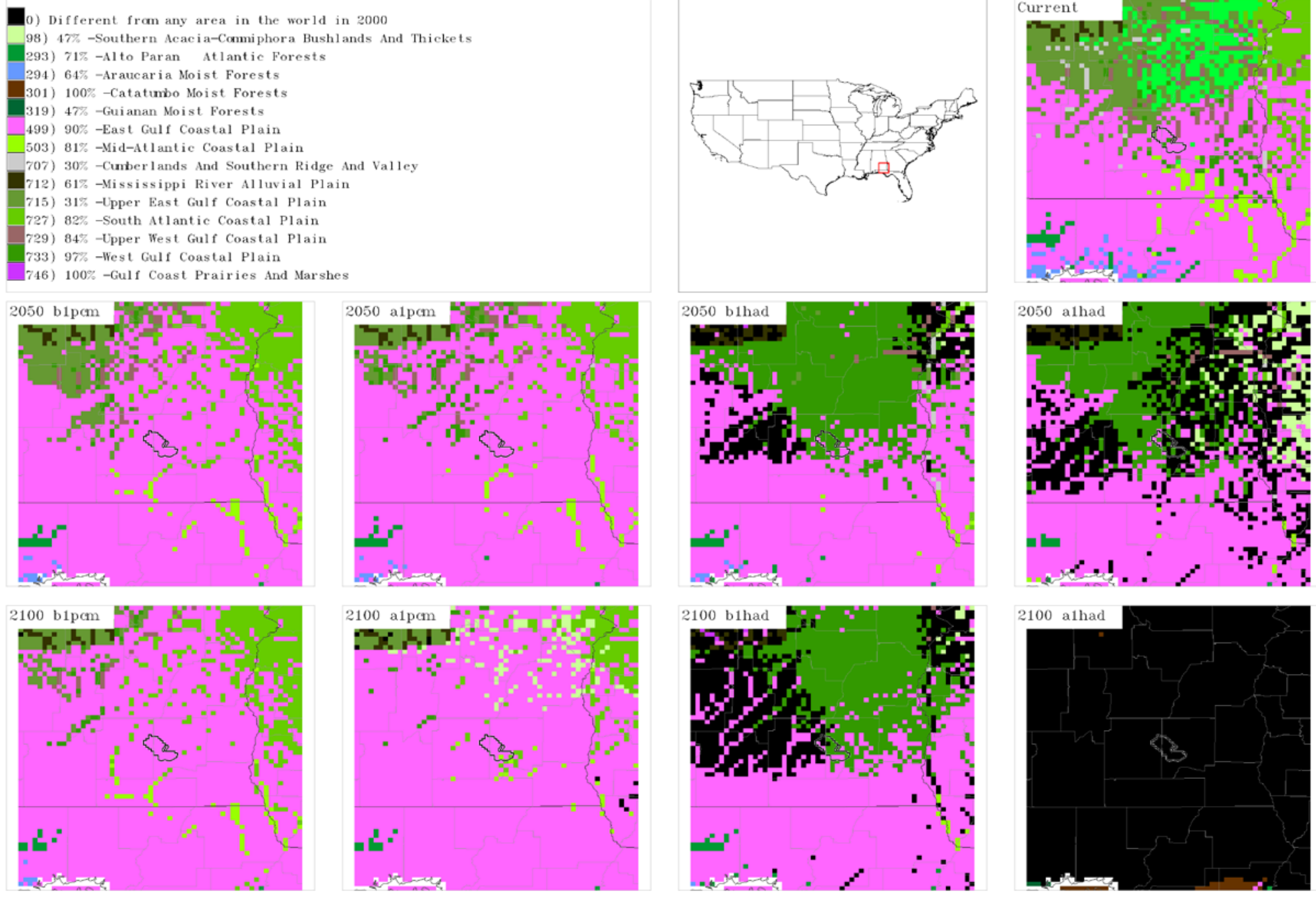
Fort Rucker Military Reservation

These images show where the

forecasted physical and climate conditions most closely match

the conditions found across the region in 2000. This answers the question, "Where can I go today to $f$ ind the forecasted conditions for this installation?"
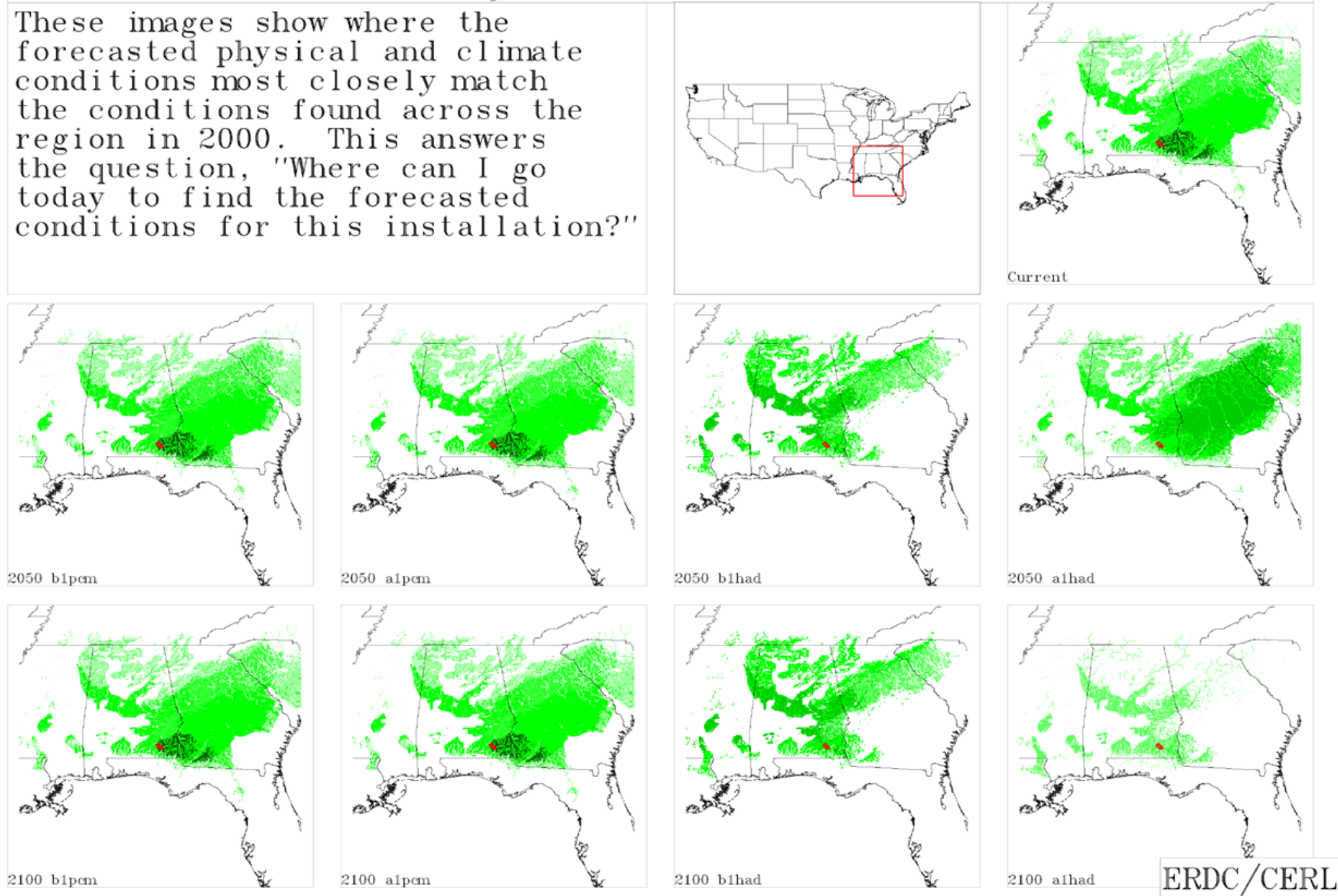

Fort Sill Military Reservation 
0) No Current US Analog

1402) Cultivated Cropland

1403) Pasture/Hay

2102) Open Water (Fresh)

5211) Apacherian-Chihuahuan Mesquite Upland Scrub

5213) Sonoran Paloverde-Mixed Cacti Desert Scrub

5216) Tamaulipan Mesquite Upland Scrub

5810) Western Great Plains Mesquite Woodland and Shrubland 7302) Central Mixedgrass Prairie

7602) Llano Uplift Acidic Forest, Woodland and Glade

8408) Modified/Managed Southern Tall Grassland
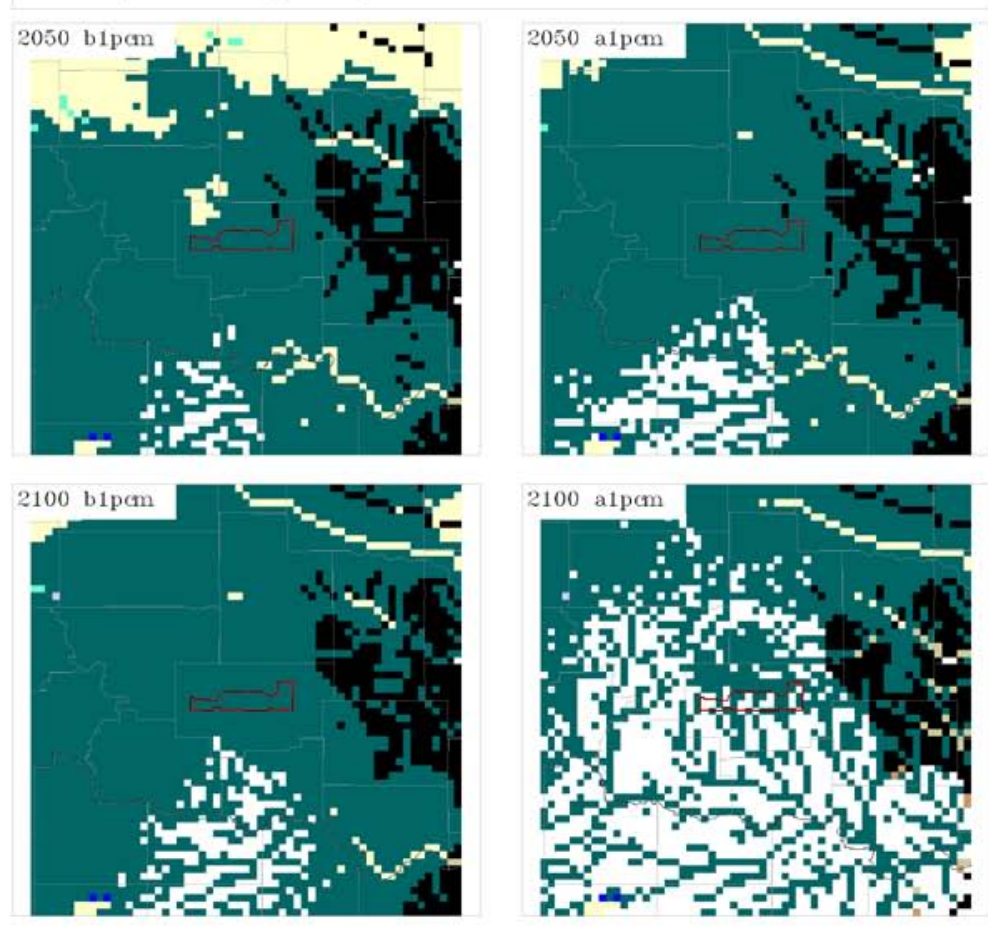
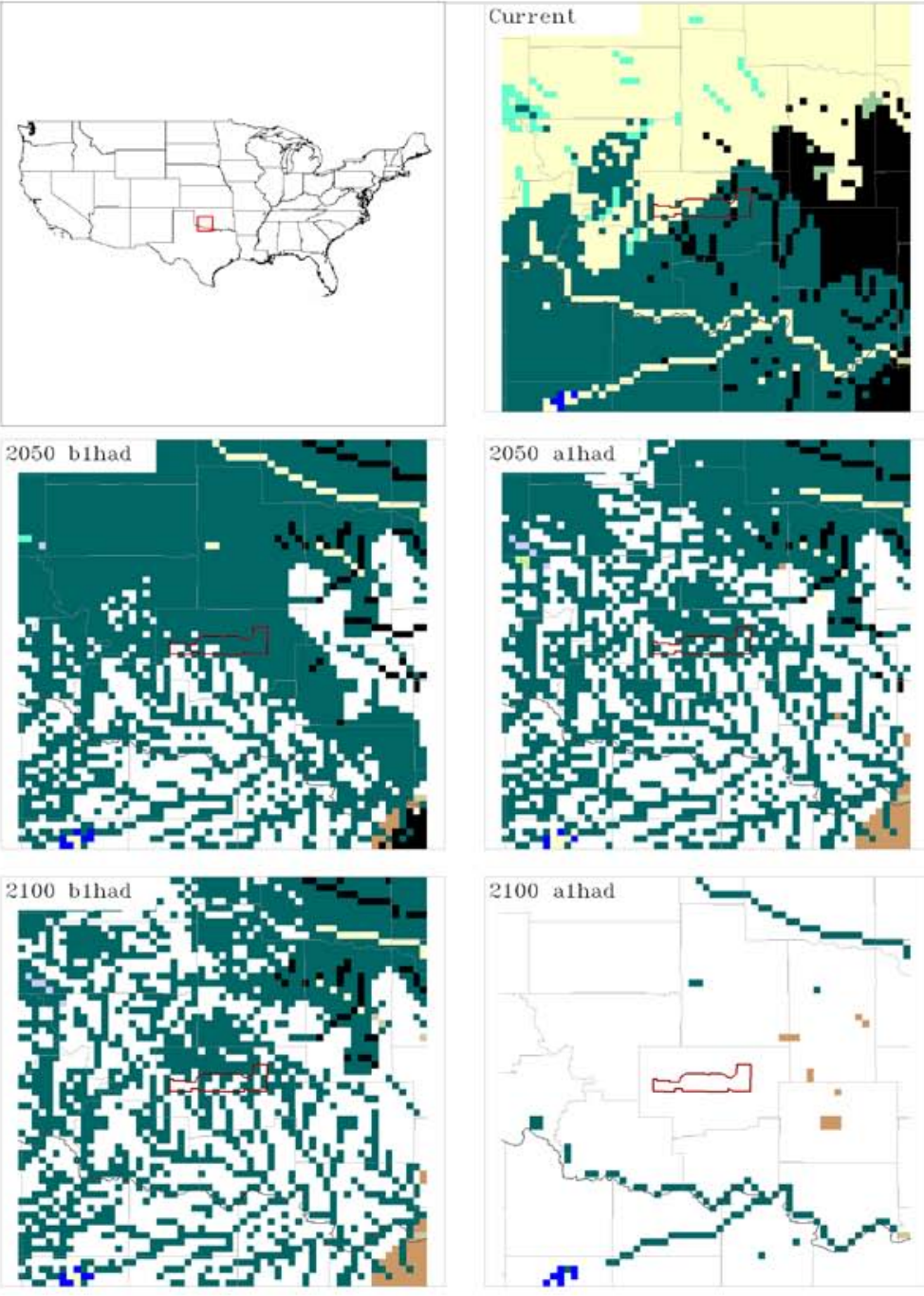
Fort Sill Military Reservation

0) Different from any area in the world in 2000
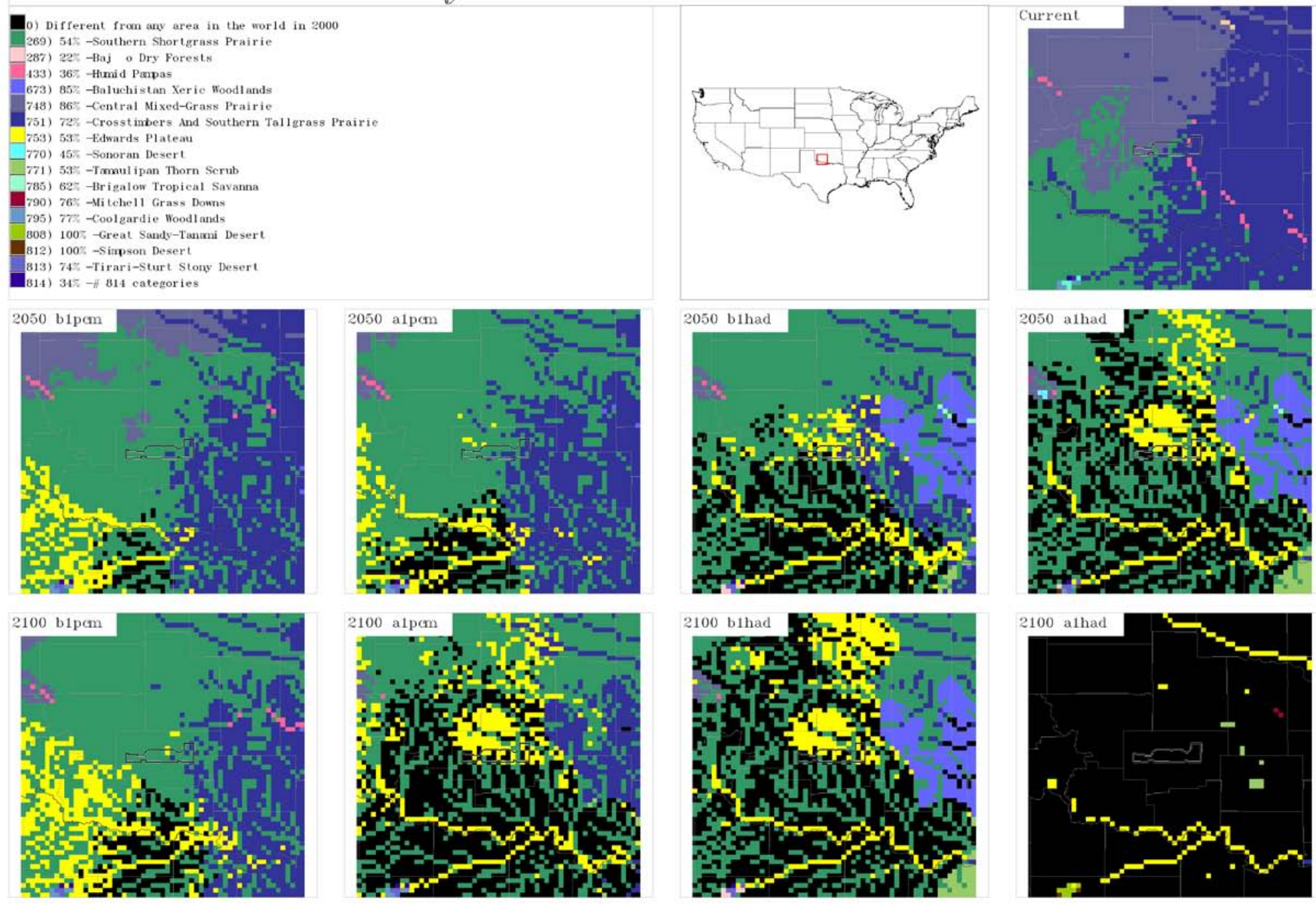
Fort Sill Military Reservation

These images show where the

forecasted physical and climate conditions most closely match

the conditions found across the region in 2000. This answers the question, "Where can I go today to find the forecasted conditions for this installation?"
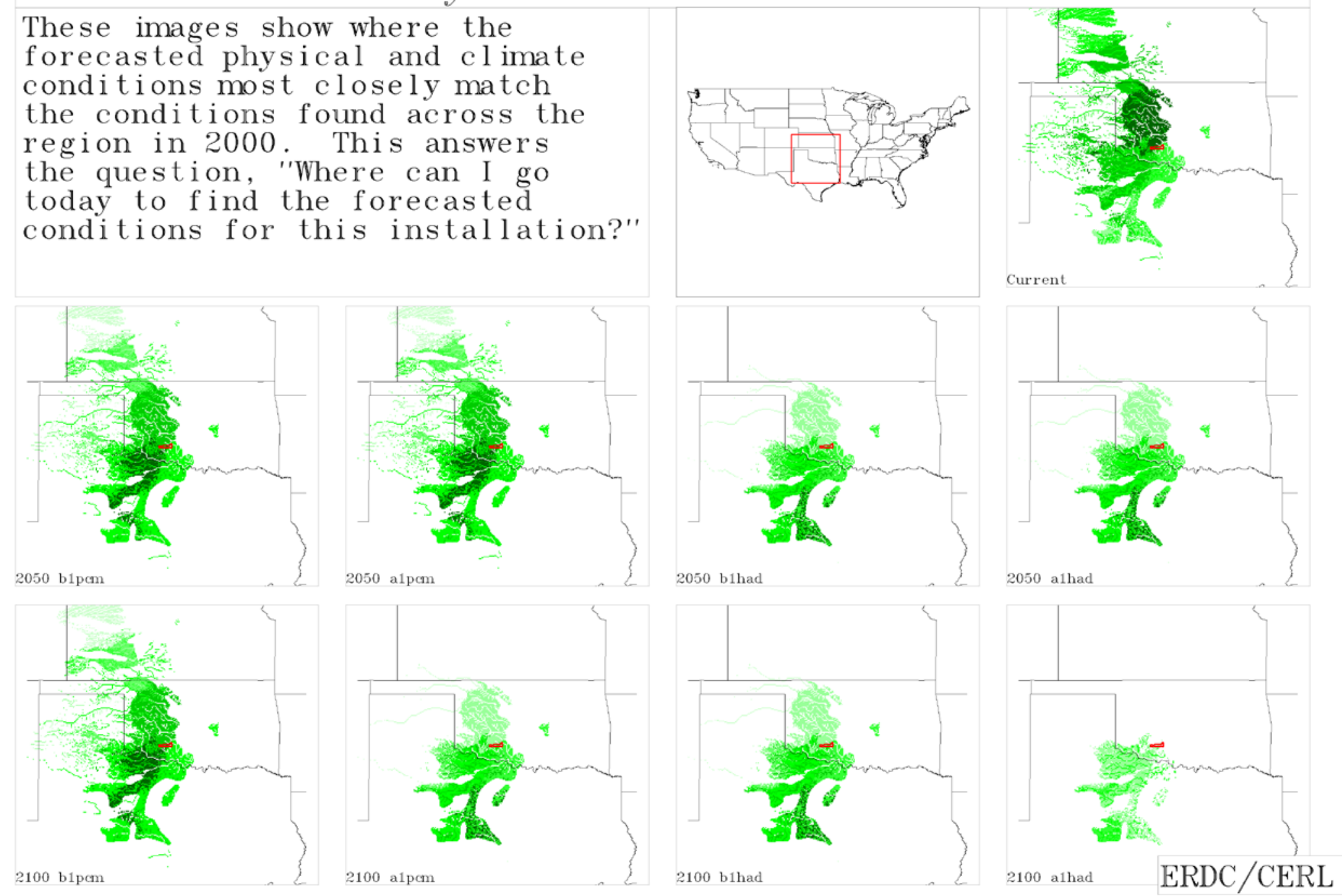

Fort Stewart 
Fort Stewart

- 0) No Current US Analog
1402) Cultivated Cropland
1403) Pasture/Hay
4212) Atlantic Coastal Plain Southern Maritime Forest
4332) West Gulf Coastal Plain Pine-Hardwood Forest
8201) Deciduous Plantations
8202) Evergreen Plantations or Managed Pine (can include dense successi
9103) Atlantic Coastal Plain Central Salt and Brackish Tidal Marsh
9219) South Florida Everglades Sawgrass Marsh
9220) Gulf and Atlantic Coastal Plain Tidal Marsh Systems
9223) Floridian Highlands Freshwater Marsh
9804) East Gulf Coastal Plain Large River Floodplain Forest - Forest Mo
9842) Atlantic Coastal Plain Small Brownwater River Floodplain Forest
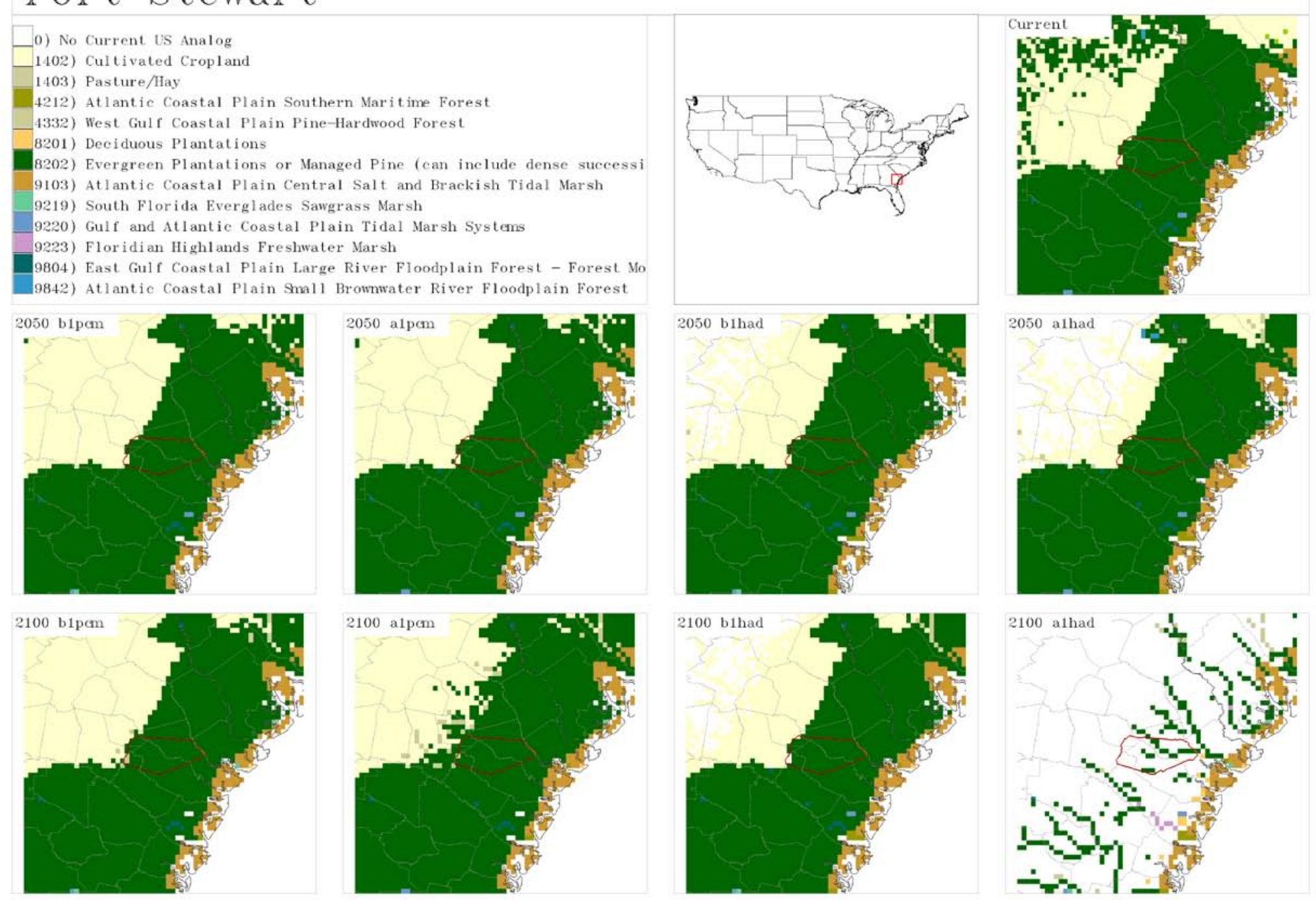
Fort Stewart

0) Different from any area in the world in 2000

98) $4 \pi$-Southern Acacia-Cami phora Bushl ands And Thickets

185) $76 \%$-Ouachita Mountains

64:- - Araucaria Voist Forests

301) $100 \%$-Catatumbo Moist Forests

355) $74 \pi$-Tropical Floridi

429) 495 - Humid Chaco

431) $70:$ - trueuayan Savanna
499) $90 \%$-East Gulf Coastal Plain

499) 908 -East Gulr Coastat
500) 335 -Florida Peninsula

503) $81 \%$ - Mid-Atlantic Coastal Plain

727) $82 \%$-South Atlantic Coastal Plain

749) $100 \%$ - Cpper West Gulf Coastal Plain

751) $72 \%$-Crosstimeers and Southern Tolles
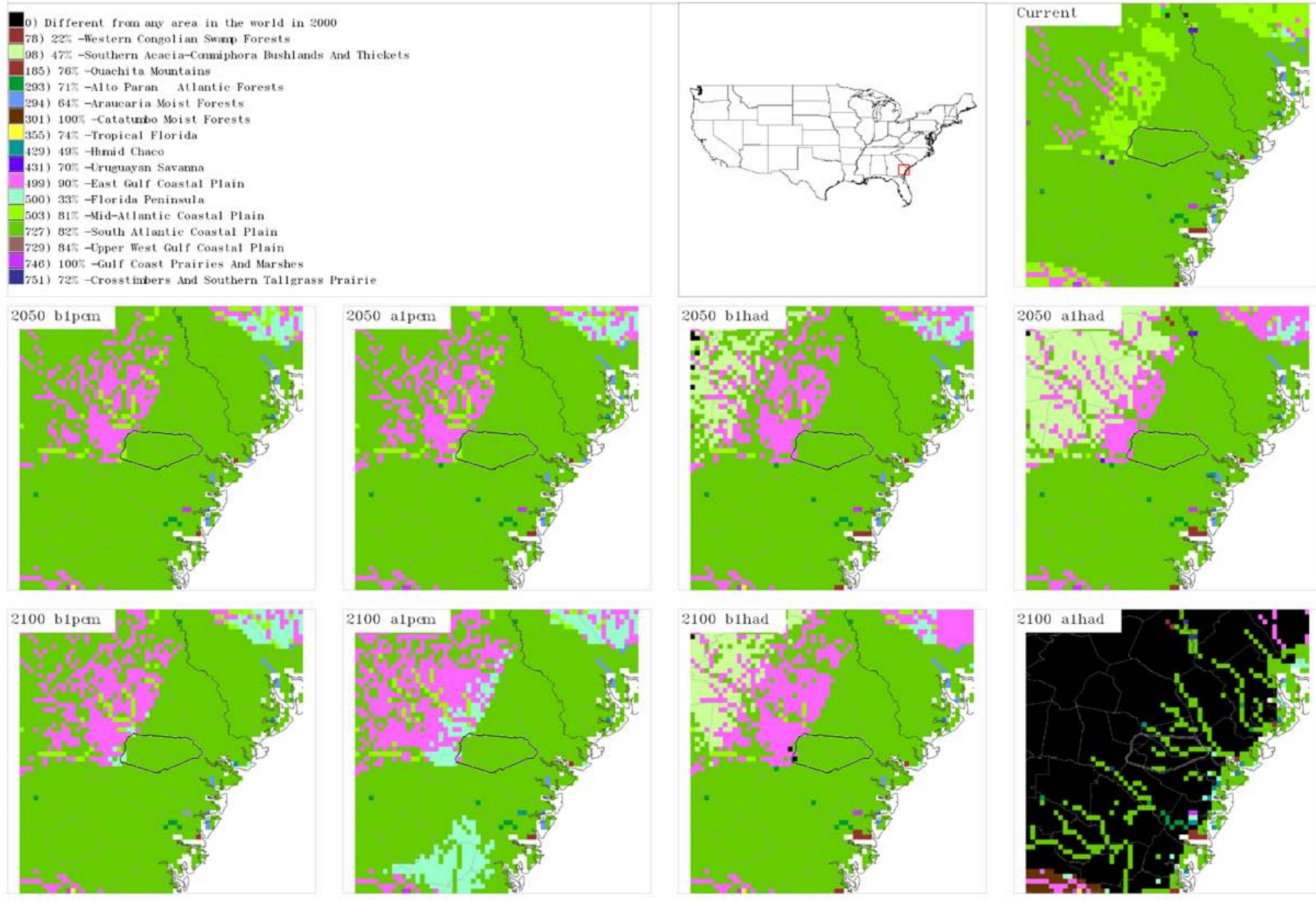
Fort Stewart

These images show where the

forecasted physical and climate conditions most closely match

the conditions found across the region in 2000. This answers the question, "Where can I go today to find the forecasted conditions for this installation?"
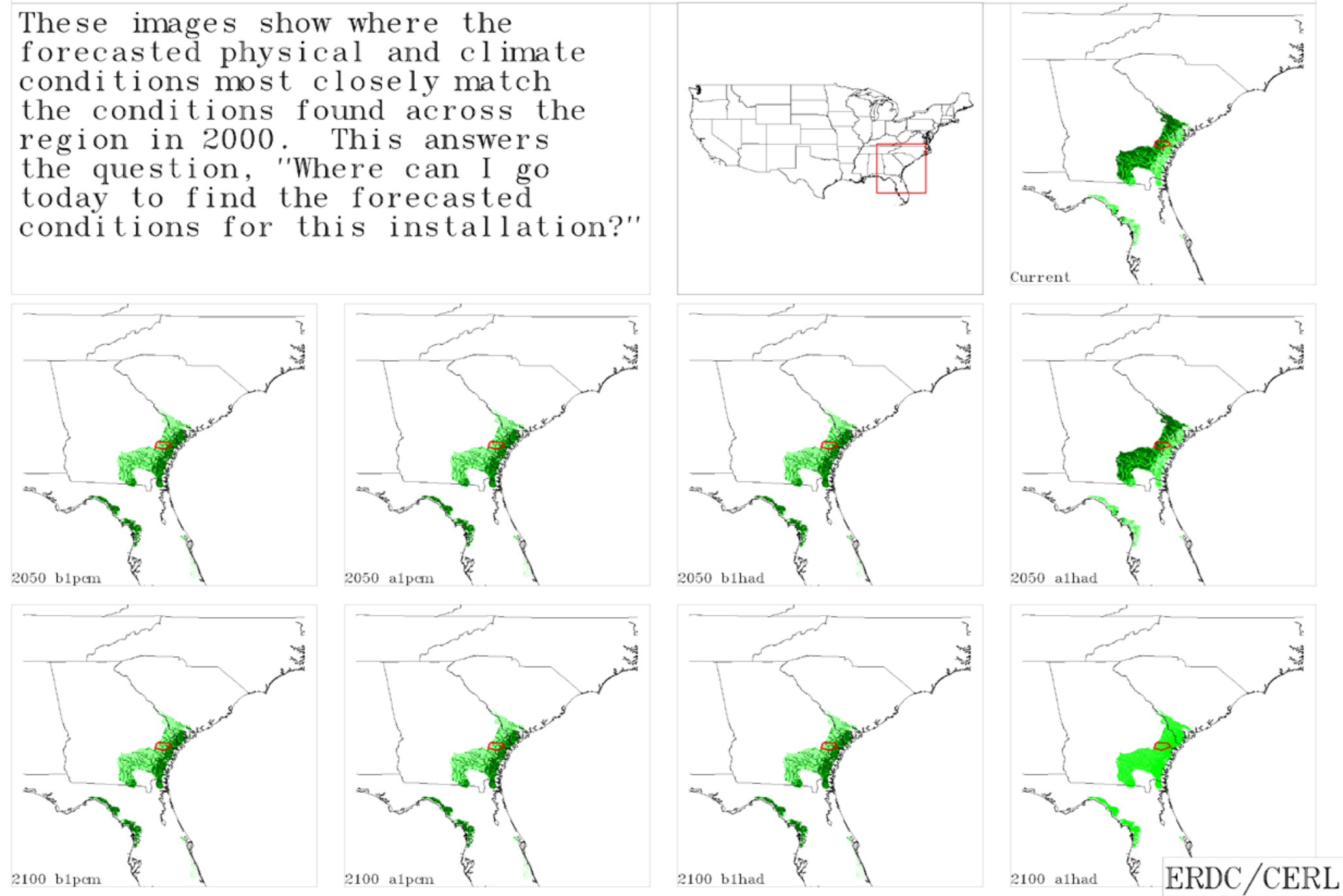

U.S. Army Aberdeen Proving Ground 
U.S. Army Aberdeen Proving Ground

416) Southern 1nterior Low Plateau Dry-Mesic Oak Forest
4126) Allegheny-Cumberland Dry Oak Forest and Foodland - Hardwood

4126) Allegheny-Cumberland Dry Oak Forest and Woodland - Hardwoood
4136) Central and South Texas Coastal Fringe Forest and Woodland

1302) Southern Piedmont Dry Oak-(Pine) Forest - Hardwood Modifier

4328) Ozark-Ouachi ta Shortleat Pine-Oak Forest and Woodl and

4330) Central Appalachian Oak and Pine Forest

4332) Nest Gulf Coastal Plain Pine-Hardmood Forest

402) South-Central Interior Mesophytic Porest

dense successional regrowthj

8203) Mannaged Tree Plantation

stal Plain Tidal Marsh Systems

9842) Atlantic Coastal Plain Small Brownwater River Floodplain Fores

- 9908) West Gulf Coastal Plain Wet Longleaf Pine Savanna and Flatwoor

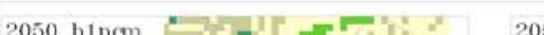
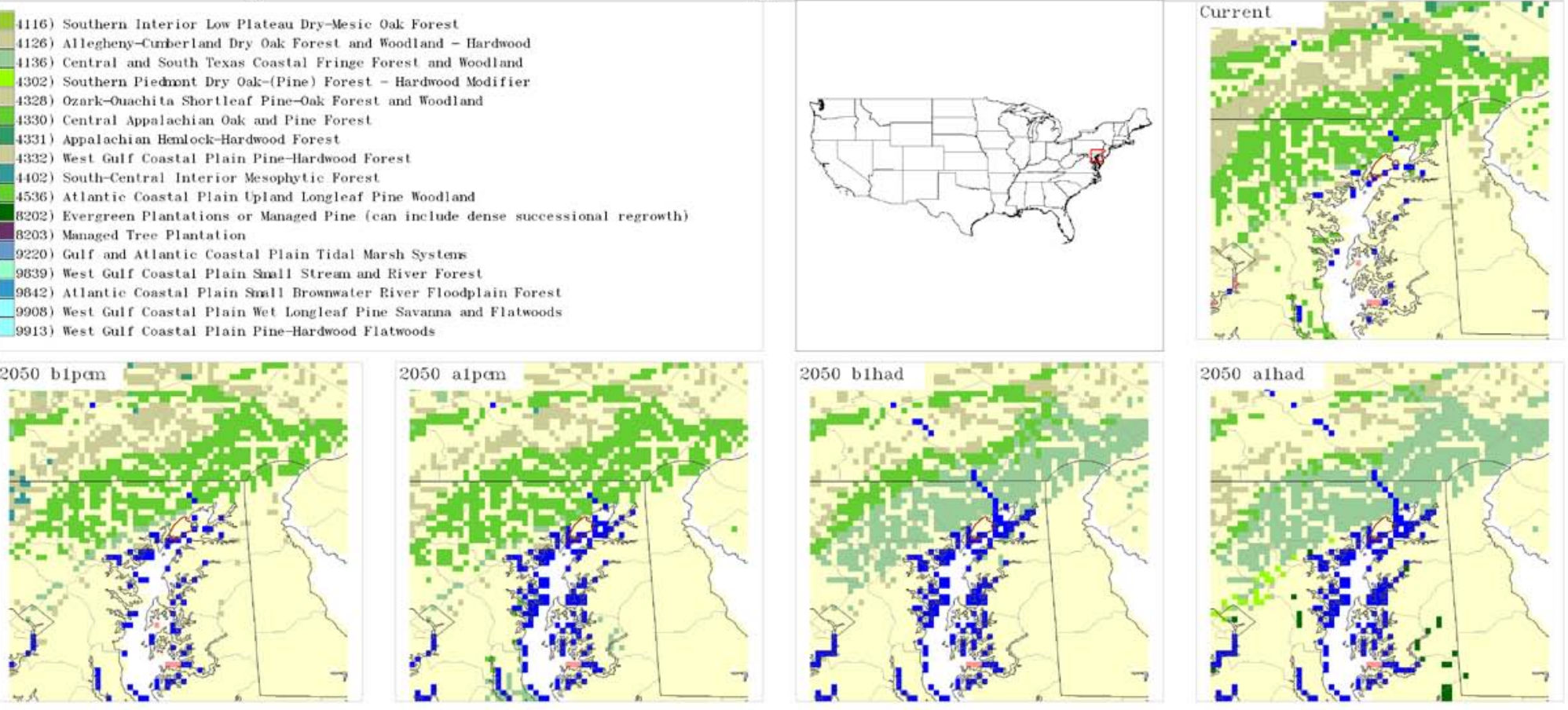

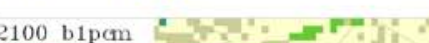

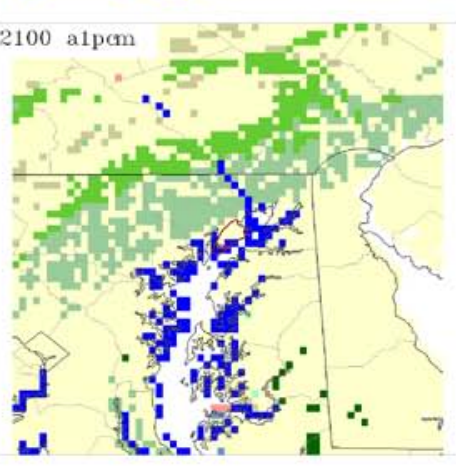

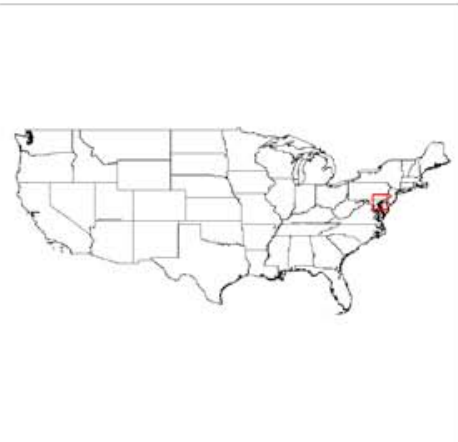

2050 b1had

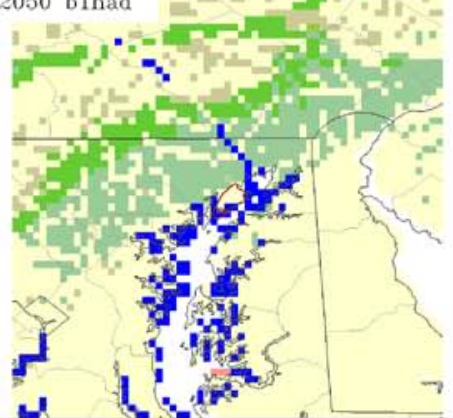

2100 b1had

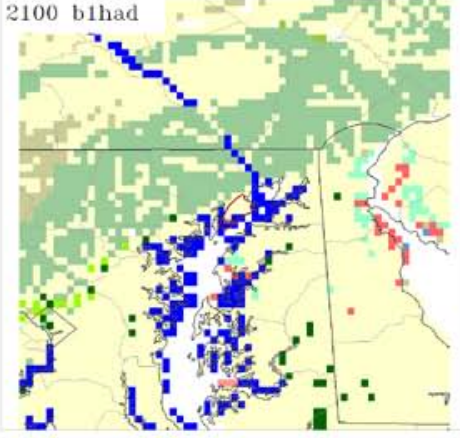
2050 alhad $=-7 \cdot-7, y=2$

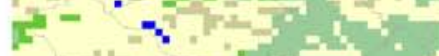

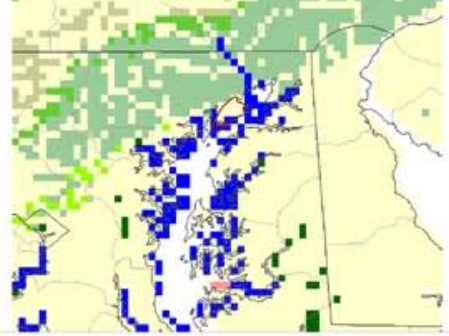

2100 alhad $=-7-\infty$.

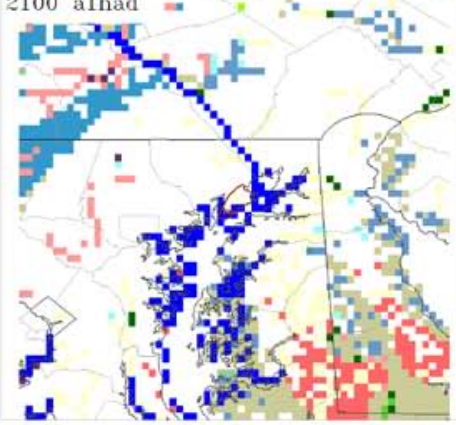


U.S. Army Aberdeen Proving Ground
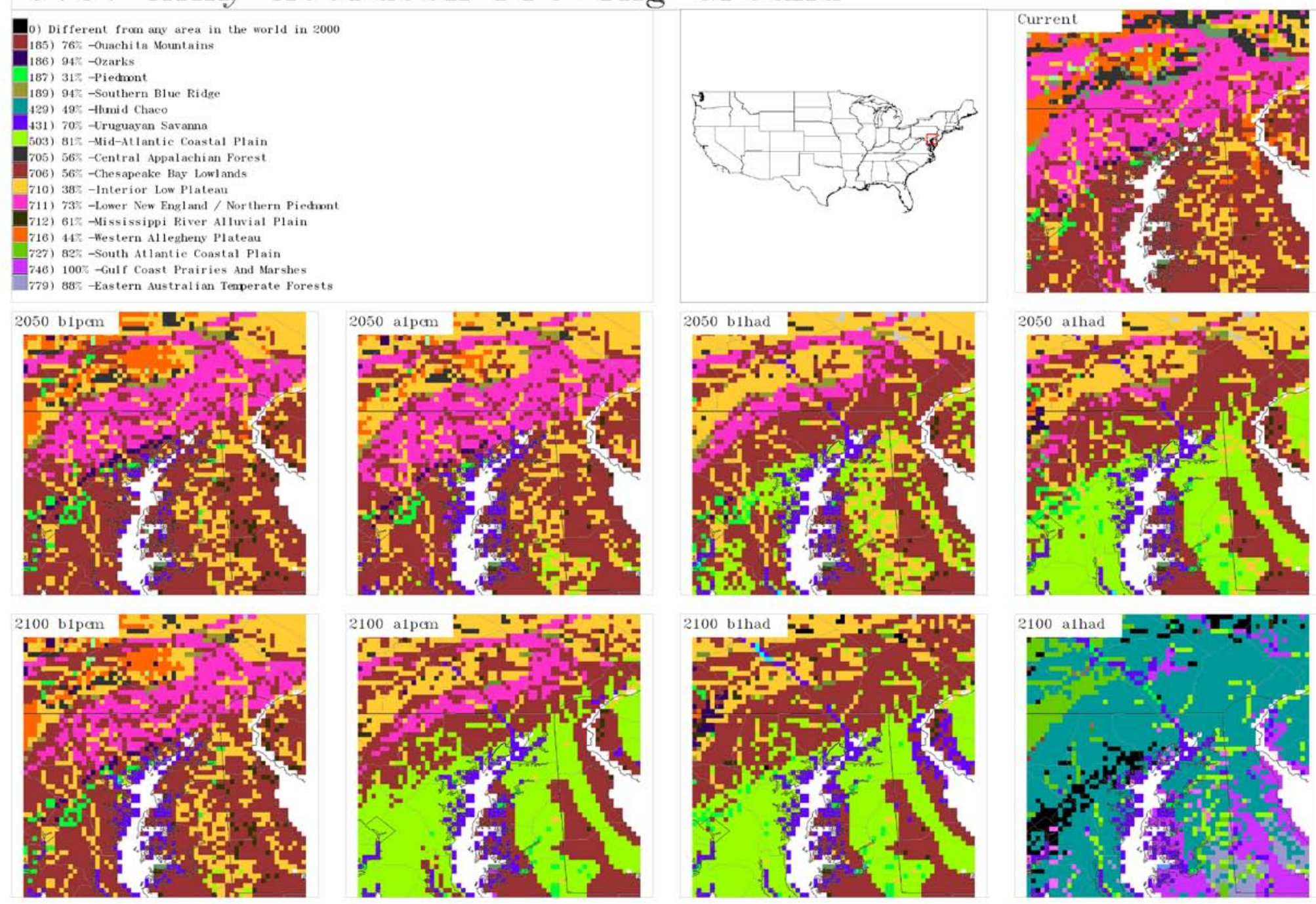
U.S. Army Aberdeen Proving Ground

These images show where the

forecasted physical and climate conditions most closely match

the conditions found across the region in 2000. This answers the question, "Where can I go today to $f$ ind the forecasted conditions for this installation?"
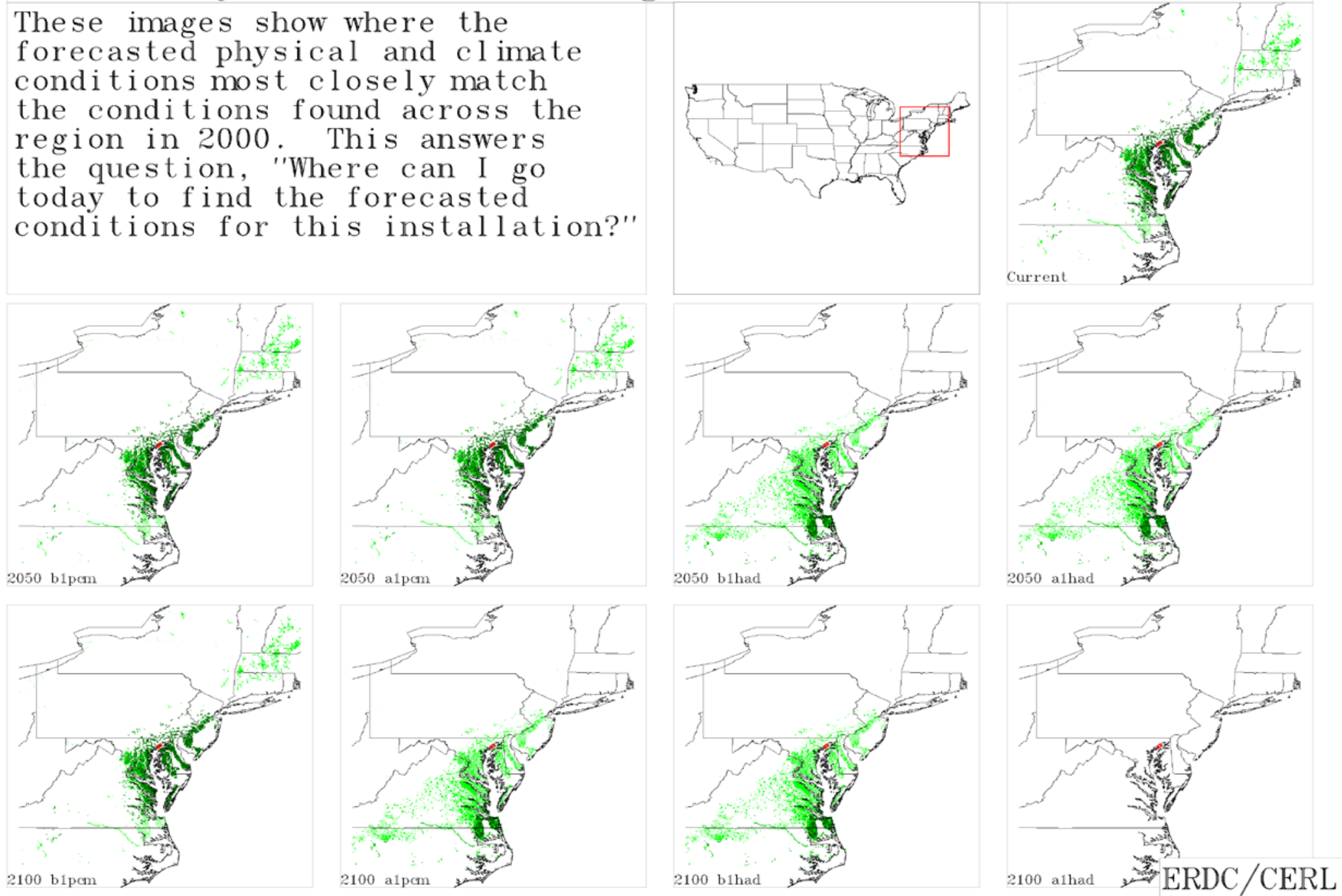

White Sands Missile Range 
White Sands Missile Range

[5212) Chihuahuan Mixed Desert and Thorn Scrub

- 5303) Apacher ian-Chihuatuan Semi-Desert Grassland and Steppe

5307) Inter-Soumtain Basins Bir Sagebrush Steppe

5308) Inter-Mountain Rasins Montane Sagebrush Steppe

5309) Inter-Houm tain Bas
5407) Sogollon Chaparral

Bot) Madrean Juniper Savanna

5706) Inter-hountain Basins Big Sagebrush Strubland

5810) Western Great Fointeand

7302) Central Kixtdoras Prairi

7306) Northerestern Great Plains Mixederass Prair

- 7309) Nestern Great Plains Sand Prairie

7310) Western Great. Plains Shorterass Prairie
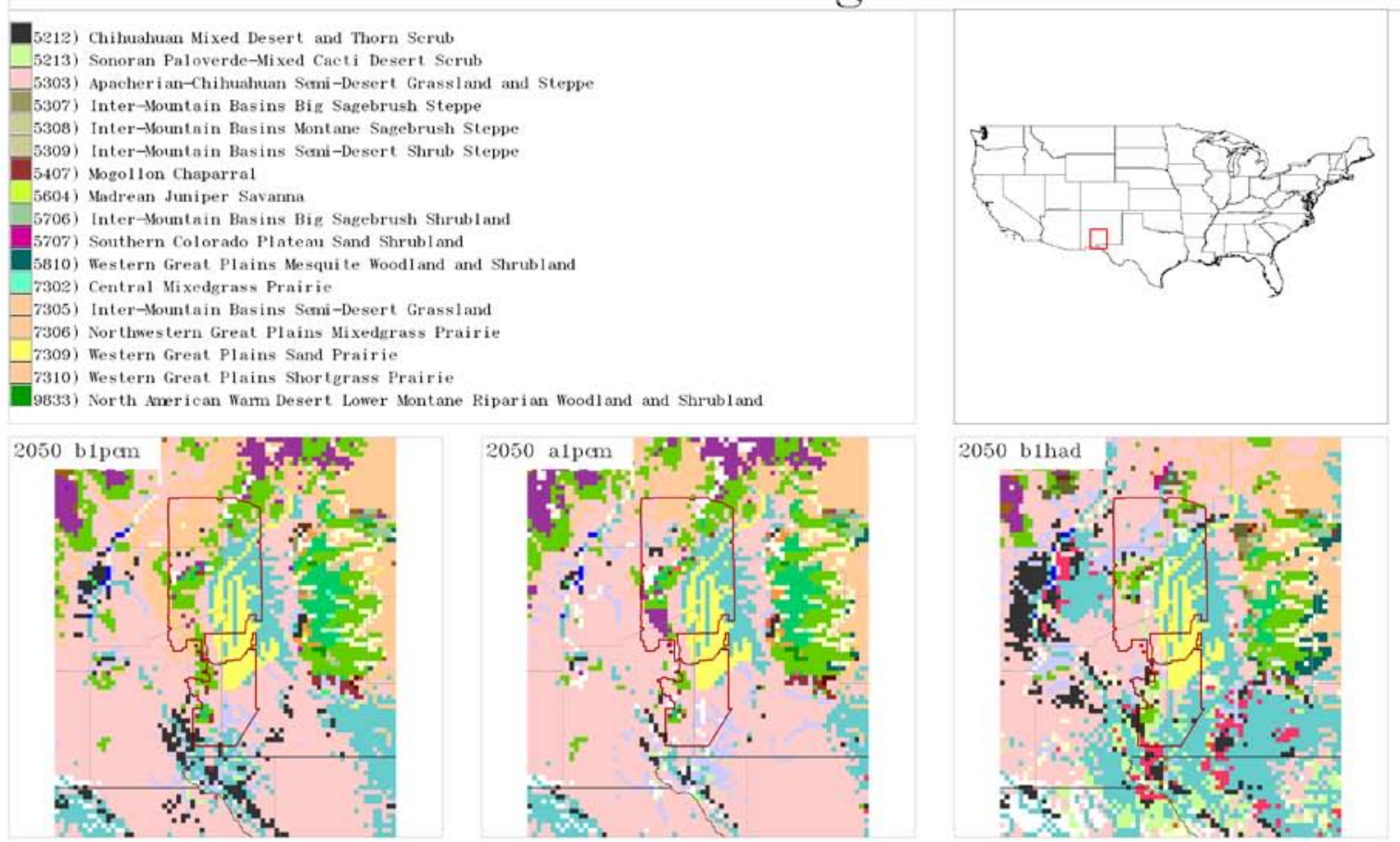

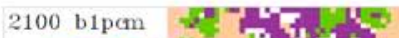
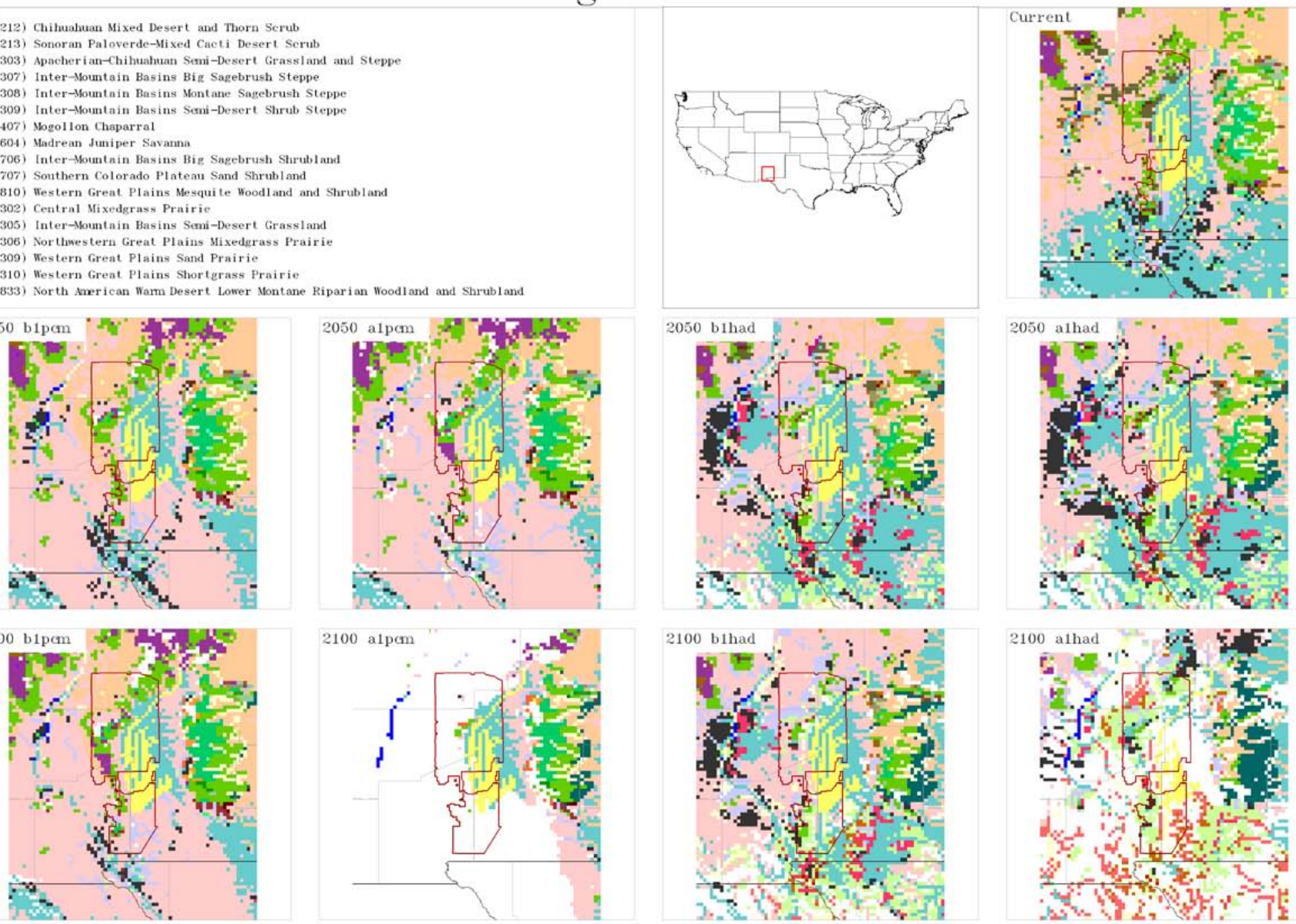
White Sands Missile Range
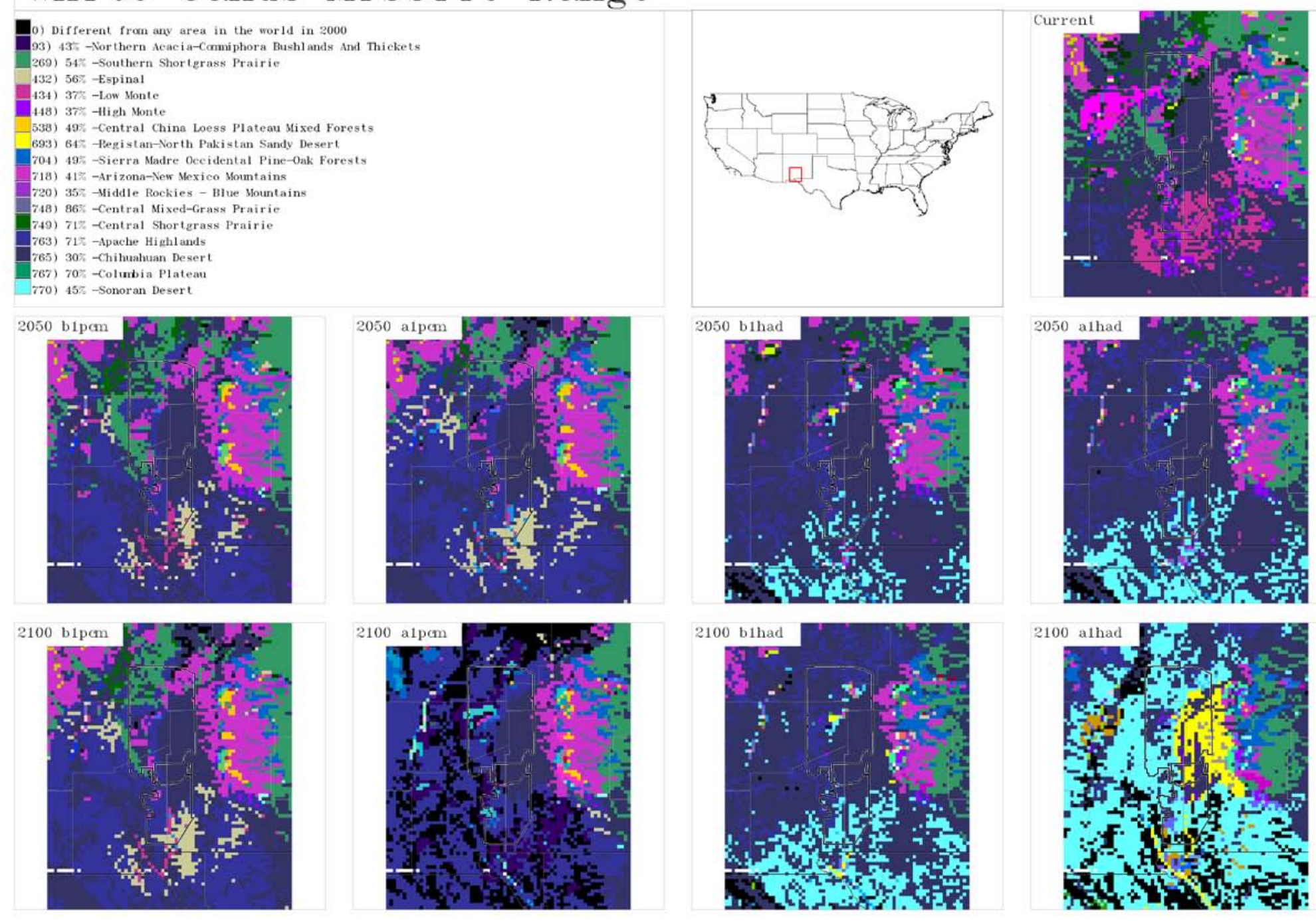
White Sands Missile Range These images show where the forecasted physical and climate conditions most closely match the conditions found across the region in 2000. This answers the question, "Where can I go today to $\mathrm{f}$ ind the forecasted conditions for this installation?"

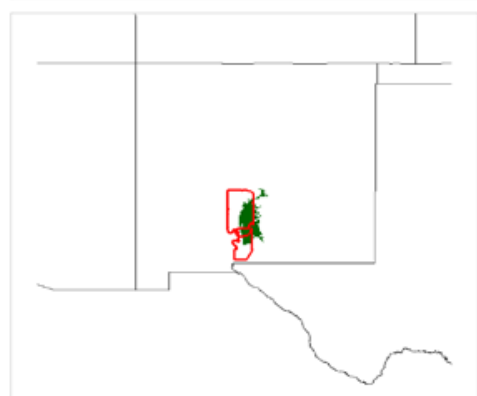

$2050 \mathrm{~b} 1 \mathrm{pcm}$

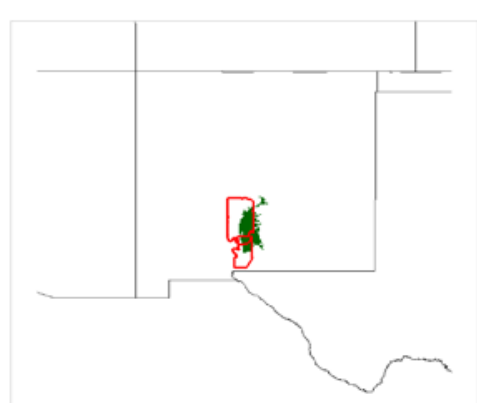

$2100 \mathrm{~b} 1 \mathrm{pcm}$

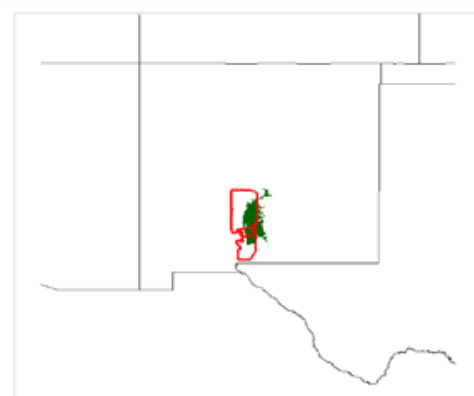

2050 a1pan

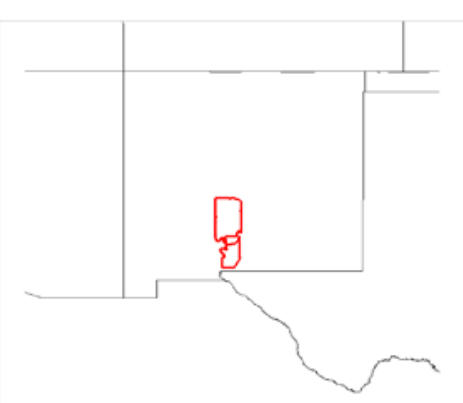

2100 a1pcm
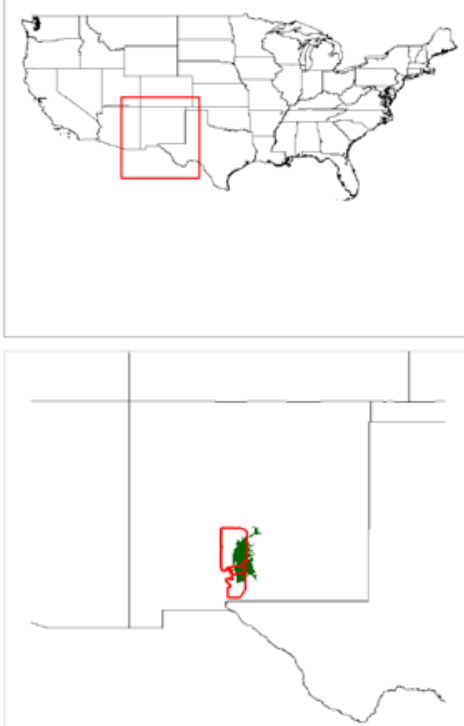

2050 b1had

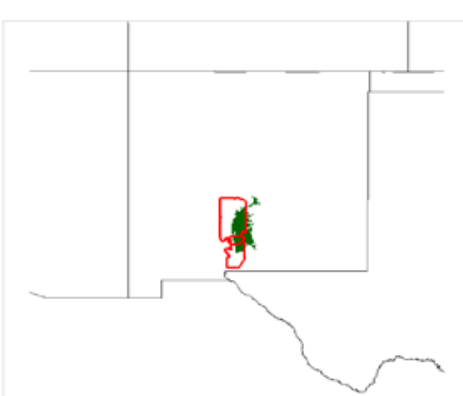

2100 b1had

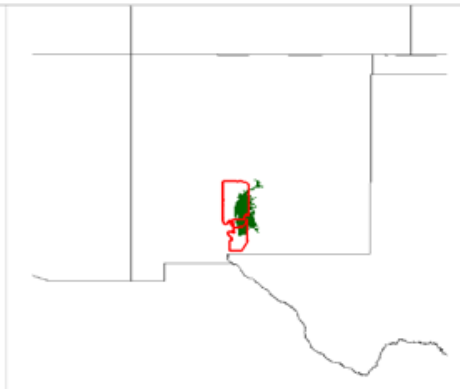

Current

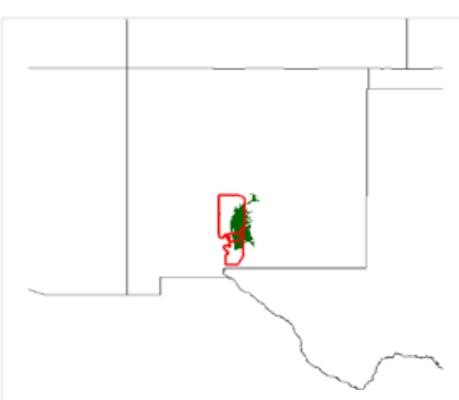

2050 a1had

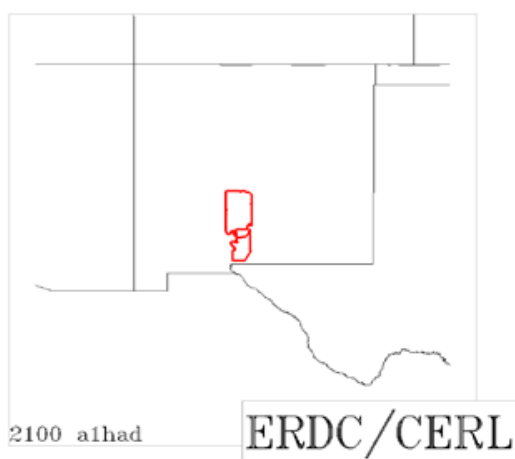

Yakima Firing Center 
Yakima Firing Center

5308) Inter-Moumtain Basins Montane Sagebrush Steppe
5403) Cal i fornia Montane Noodl and and Chaparral

5403) Cal i fornia Montane Woodl and and Chaparra
5410) Southern Cal i fornia Dry-Mesic Chaparral

5501) California Central Valley Mixed Oalk Savanna

Cofifornia tower Mont ane Blue Oak-Poothill Pine Woodl and and Savann

5702) Colmbia Plateau Scabland Shrubland

5706) Inter-Sountain Basins Big Sagebrush Shrubland

7203) Northern Rocky Mountain Lower Montane, Foothill and Valley Grassland

7304) Colmòia Basin Foothill and Canyon Dry Grassland

7501) California Central Valley and Southern Coastal Grassland

8106) Harvested forest-tree rege
8304) Recently burned shrubland

8404) Introduced Upland Vegetation - Annual Grassland

9227) North Awrican Arid West Furergent Marsh
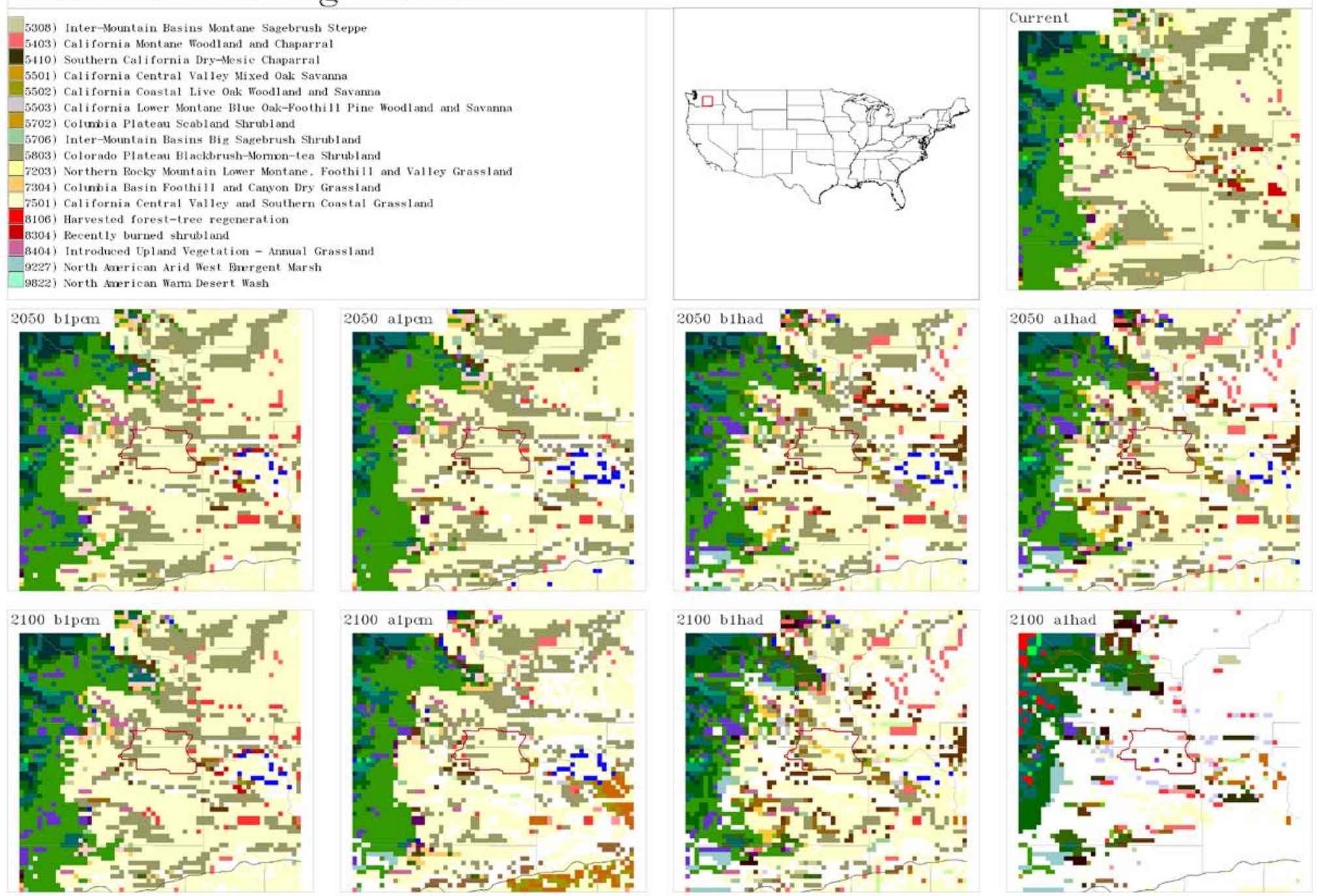
Yakima Firing Center

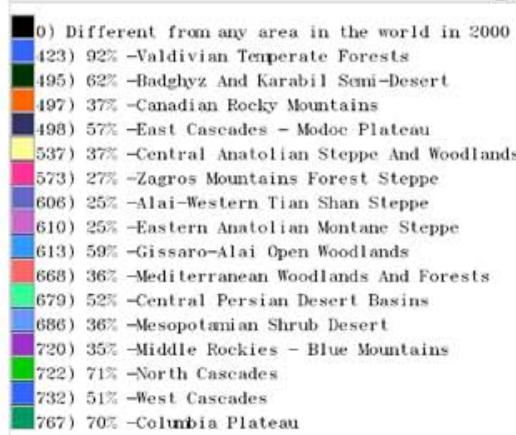
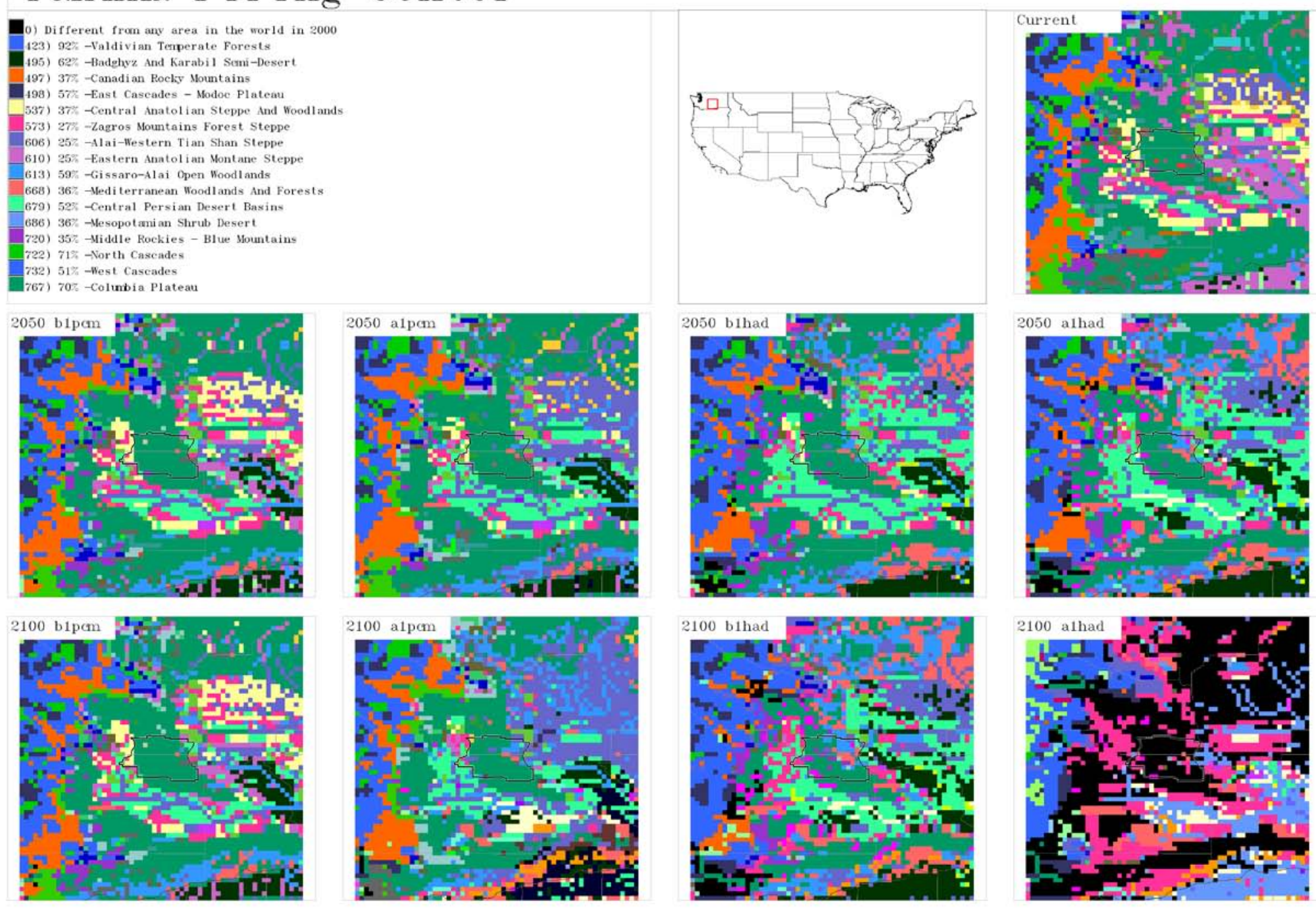
Yakima Firing Center

These images show where the forecasted physical and climate conditions most closely match the conditions found across the region in 2000. This answers the question, "Where can I go today to $f$ ind the forecasted conditions for this installation?"
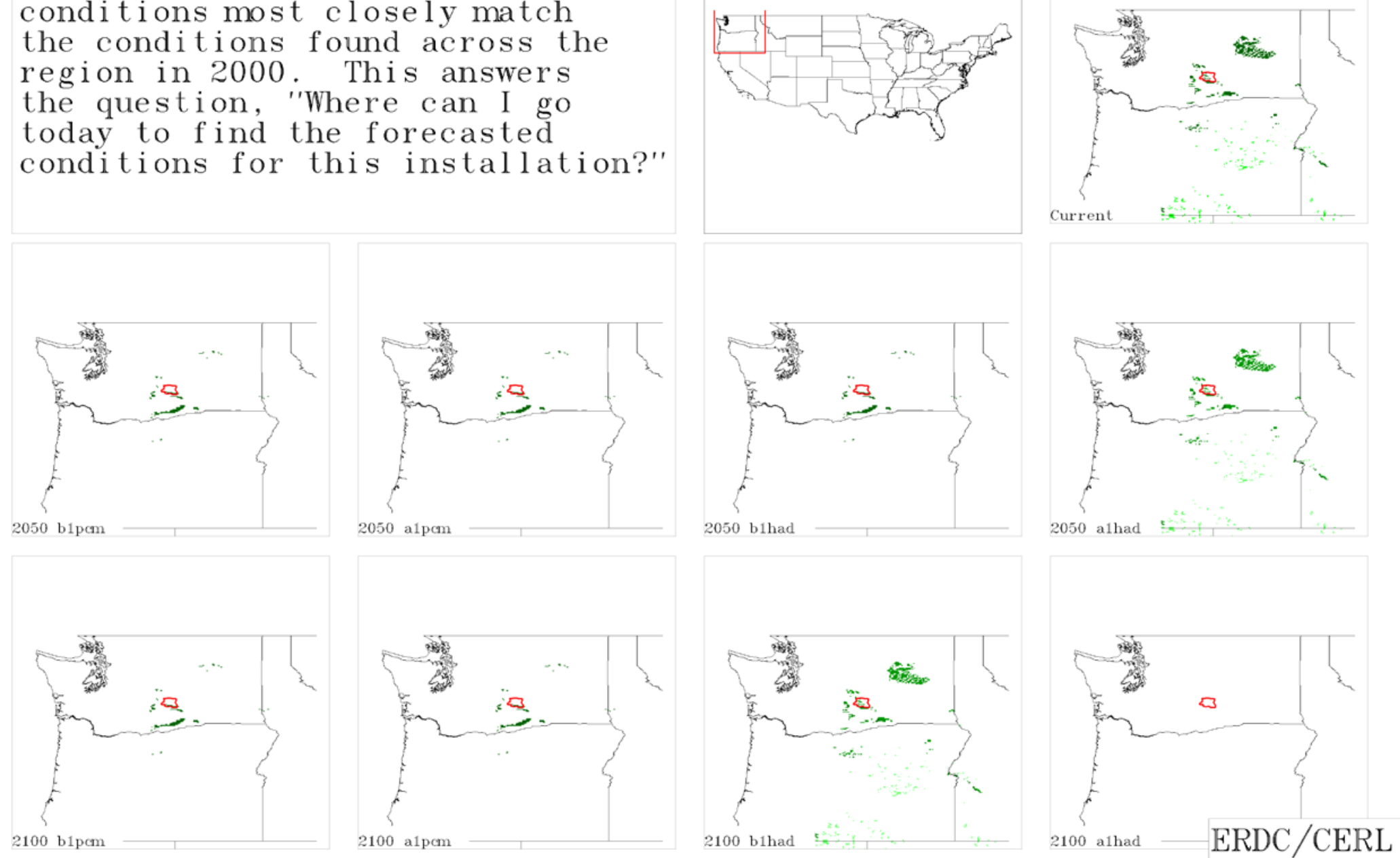

\section{Yuma Proving Ground}


Yuma Proving Ground

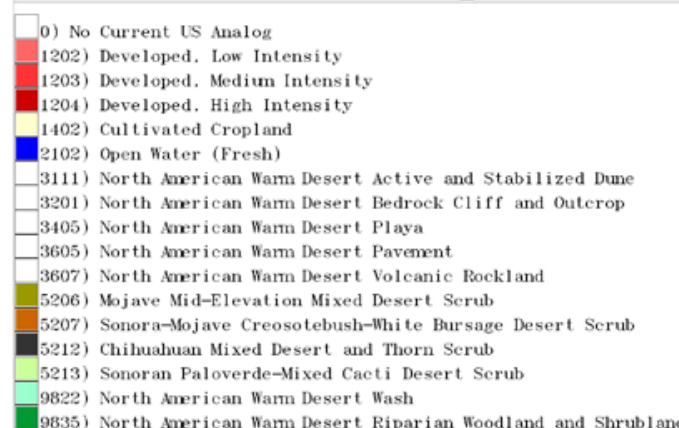

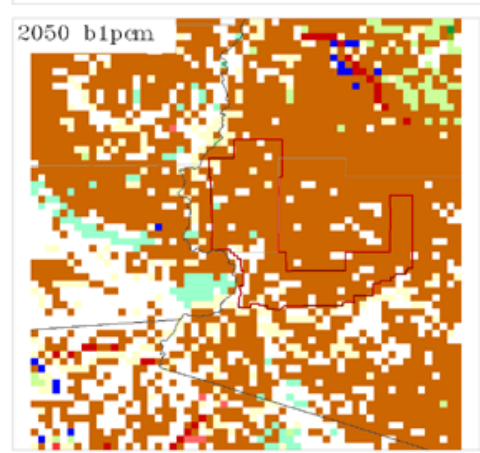

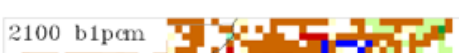

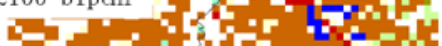

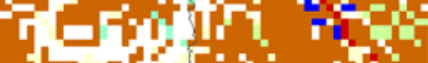

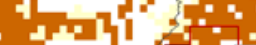

7. "

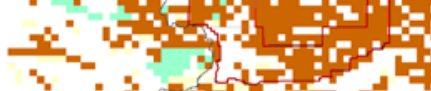
" 굴

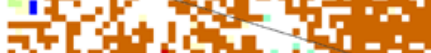

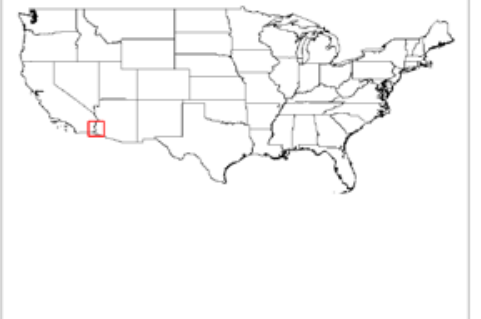

2050 b1had IF

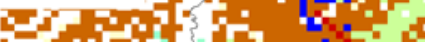
분,

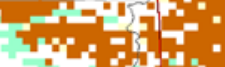
"

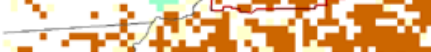

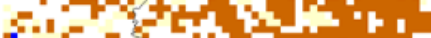

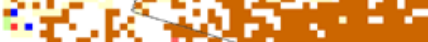

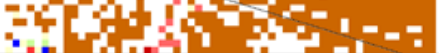
2100 b1had -"

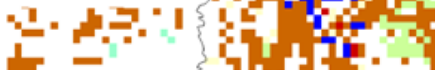
1. - -

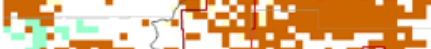
$\because x^{2}-10$

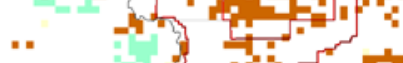
(1) 1-1.

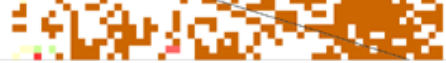

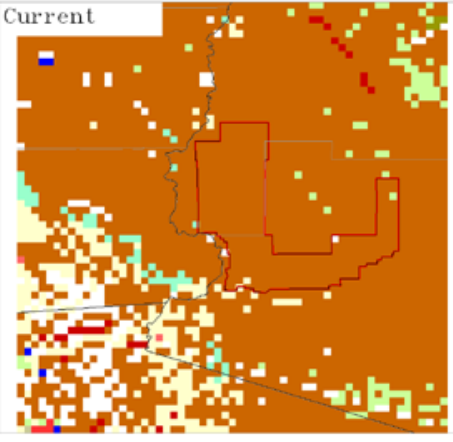

2050 alhad $=5$

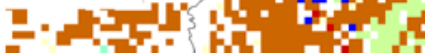
- ="1" anch

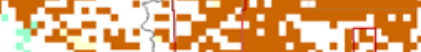
mons - -. "1 ". $\mathrm{CO}+\mathrm{CH}$ :

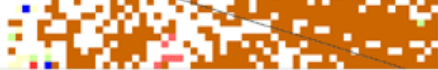
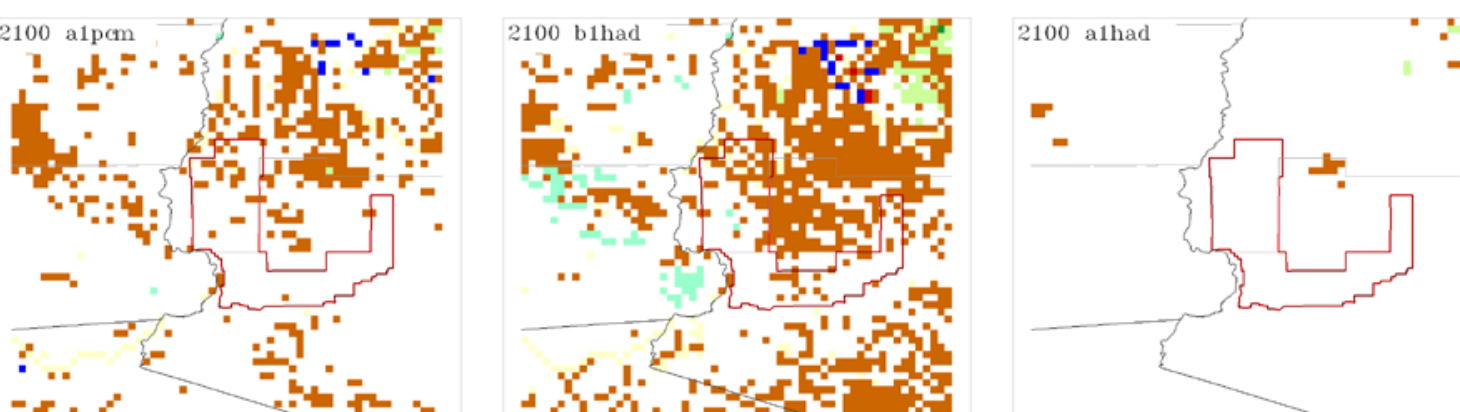

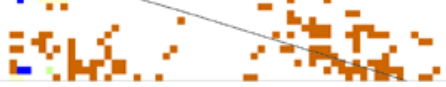


Yuma Proving Ground
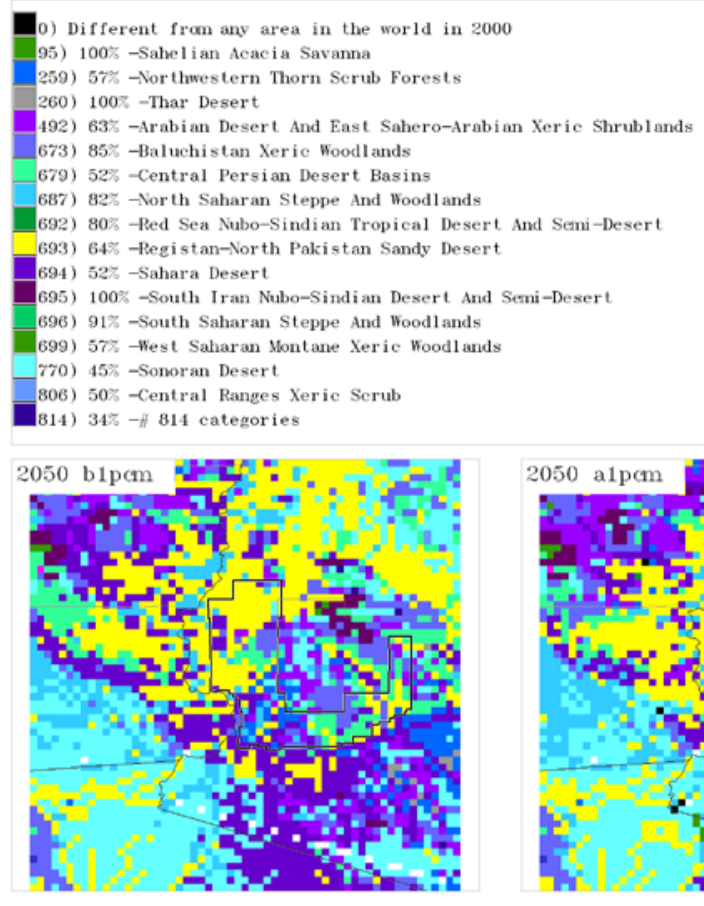

492) $63 \%$-Arabian Desert And East Sahoro

(2) jer -central Persian Desert Basins

694) $52 \%$-Sahara Desert

rt And Semi-Desert

Woodl ands

Xeric Scru
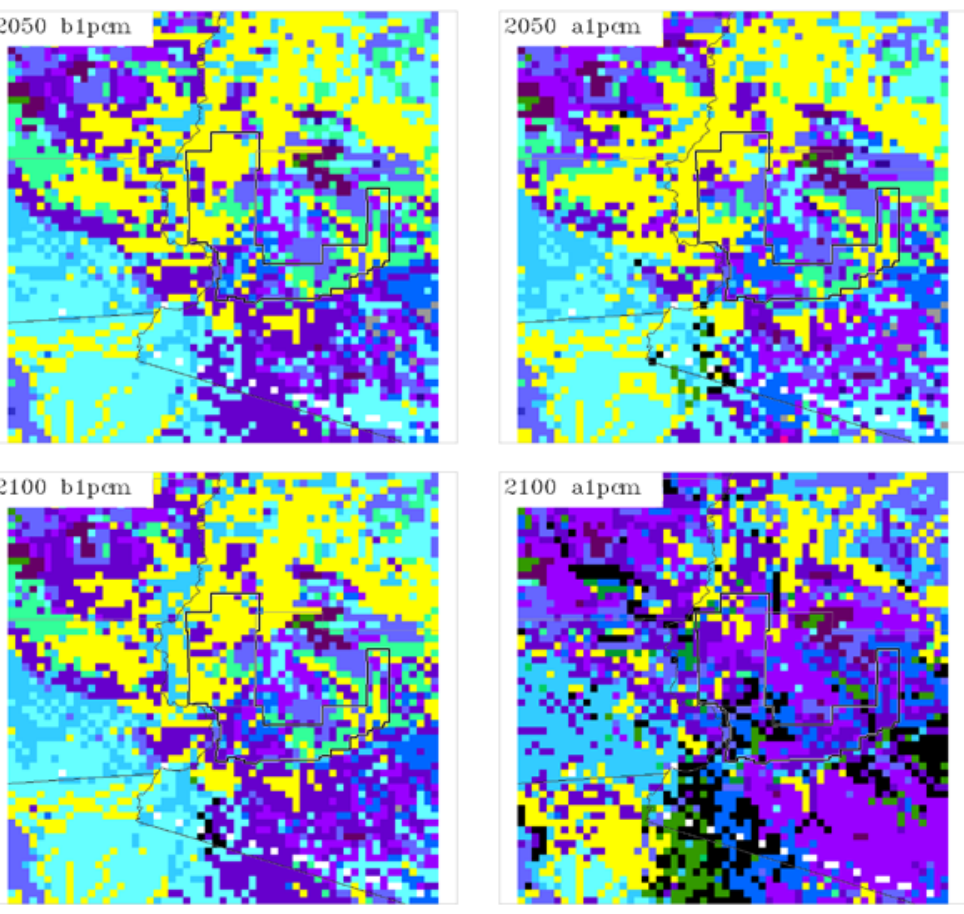
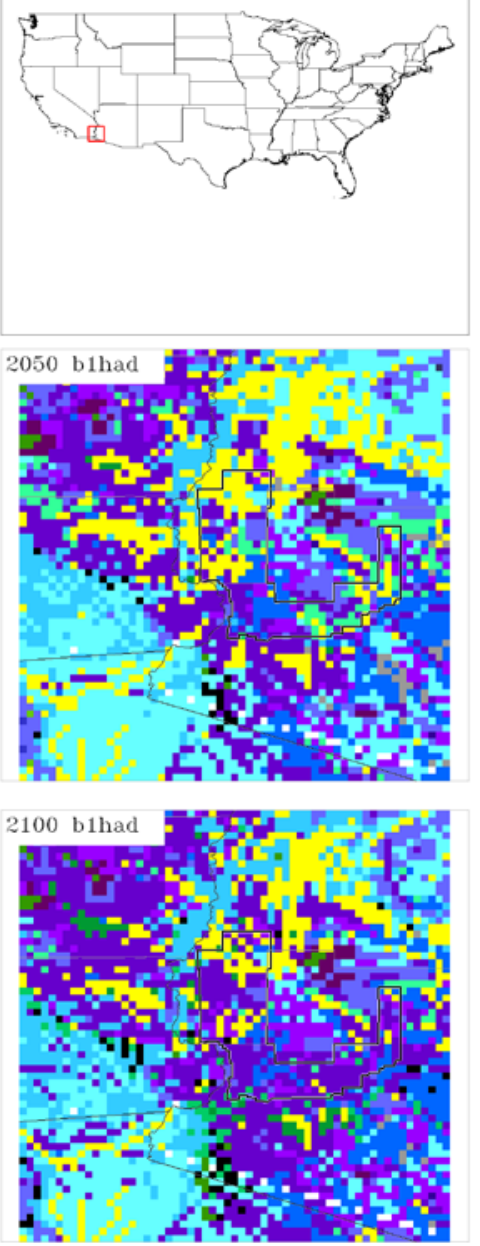
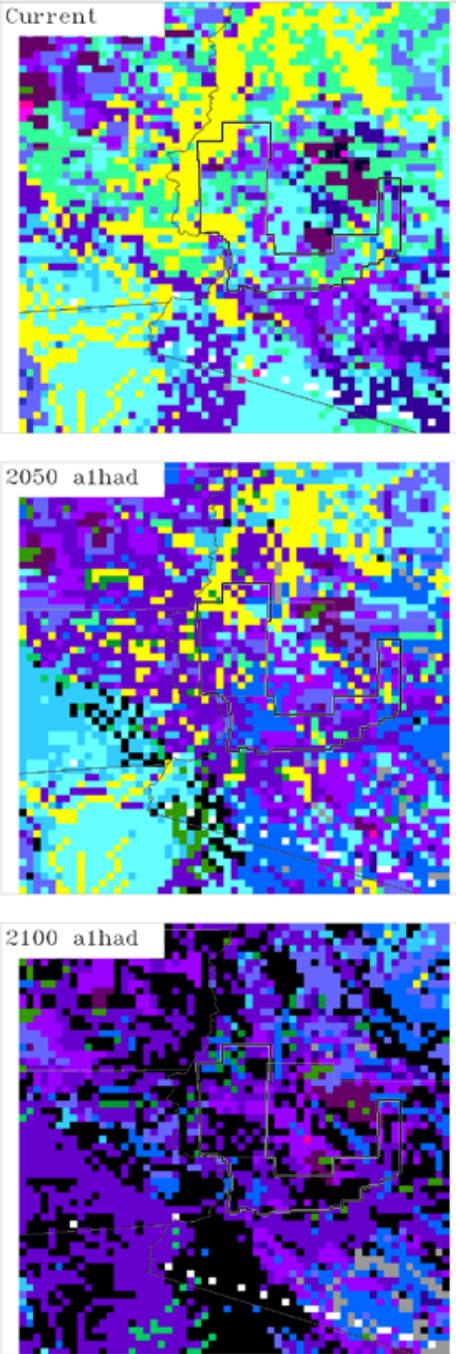


\section{Yuma Proving Ground}

These images show where the forecasted physical and climate conditions most closely match the conditions found across the region in 2000. This answers the question, "Where can I go today to find the forecasted conditions for this installation?"
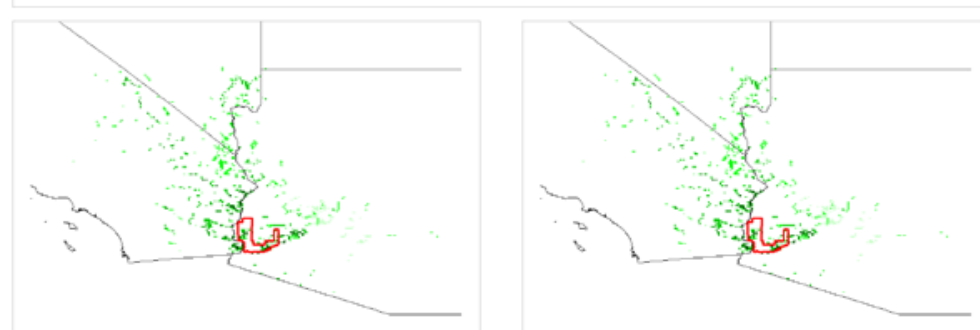

$2050 \mathrm{~b} 1 \mathrm{pcm}$

2050 a1pcm

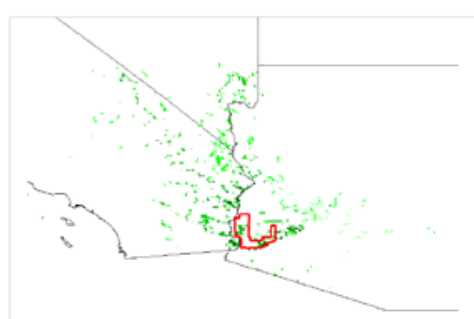

$2100 \mathrm{~b} 1 \mathrm{pcm}$

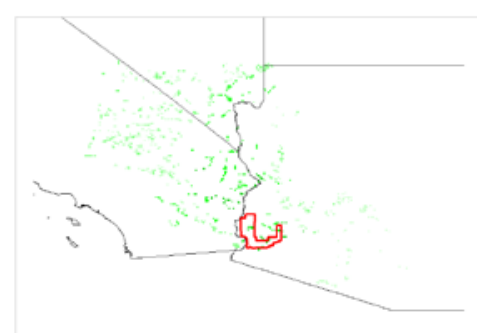

$2100 \mathrm{a} p \mathrm{pcm}$
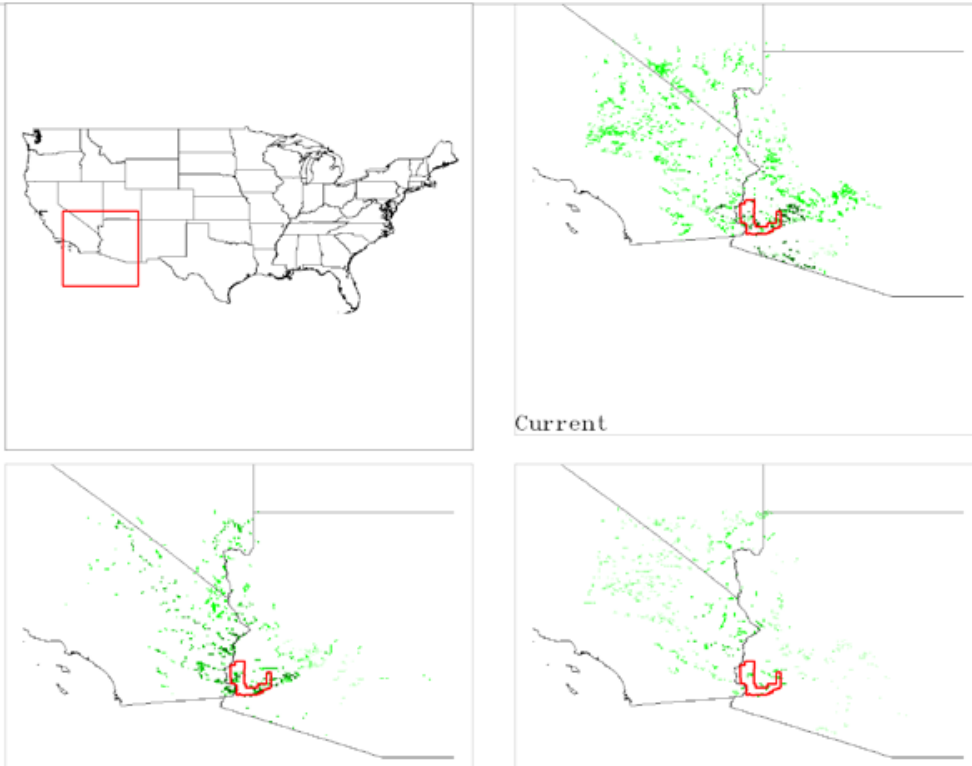

2050 b1had

2050 a1had

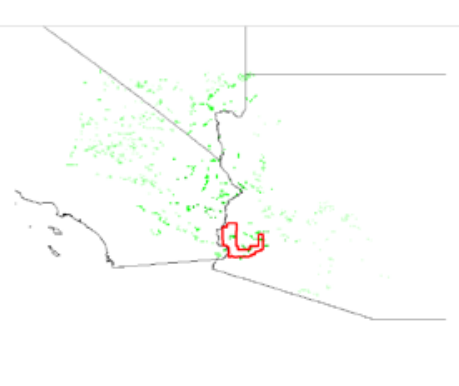

2100 b1had

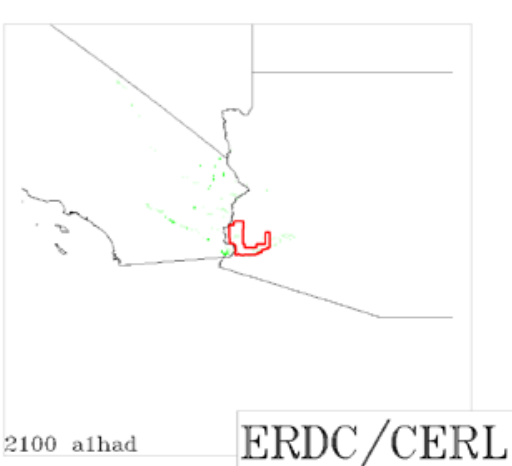




\section{Appendix C: Ranking Army Installations}

Which installations are most at-risk for change due to the consequences of potential ecosystem shift? To rank-order installations, the boundary of each installation was used to "cookie-cutter" into the current and future maps over the eight future GAP-based maps to tabulate the ecosystem type and amount of each type. For each future map, the percent of the installation that still held the current ecosystem types was calculated. The percentage across all eight future maps was then averaged and used to rankorder the installations. The following table lists all of the Army installations ranked by their "risk for change," beginning with the least changeable and ending with the installations likely to be most dramatically affected.

The change counts for each of the model/scenario/time combination are listed in the columns with the average of these (not listed) used to sort the table. The color-breaks are arbitrarily set at 80 and 50 percent. 


\begin{tabular}{|c|c|c|c|c|c|c|c|c|c|}
\hline Legend: & & & & & & & & & \\
\hline \multicolumn{10}{|c|}{ Percent Habit Unchanged By Climate Change } \\
\hline \multicolumn{10}{|l|}{$80-100 \%$ unchanged } \\
\hline \multicolumn{10}{|l|}{$50-80 \%$ unchanged } \\
\hline \multicolumn{10}{|l|}{ 0-50\% unchanged } \\
\hline & & \multicolumn{4}{|c|}{ PCM Model } & \multicolumn{4}{|c|}{ Hadley Model } \\
\hline & & \multicolumn{2}{|c|}{ Low Emissions } & \multicolumn{2}{|c|}{ High Emissions } & \multicolumn{2}{|c|}{ Low Emissions } & \multicolumn{2}{|c|}{ High Emissions } \\
\hline Installation & $\begin{array}{c}\text { Size }(0.02 \times 0.02) \\
\text { degree cells }\end{array}$ & $\begin{array}{l}\text { PCM B1 } \\
2050\end{array}$ & $\begin{array}{l}\text { PCM B1 } \\
2080\end{array}$ & $\begin{array}{c}\text { PCM A1 } \\
2050\end{array}$ & $\begin{array}{l}\text { PCM A1 } \\
2080\end{array}$ & $\begin{array}{c}\text { HAD B1 } \\
2050\end{array}$ & $\begin{array}{l}\text { HAD B1 } \\
2080\end{array}$ & $\begin{array}{l}\text { HAD A1 } \\
2050\end{array}$ & $\begin{array}{l}\text { HAD A1 } \\
2080\end{array}$ \\
\hline Camp Adair Military Reservation & 2 & 100 & 100 & 100 & 100 & 100 & 100 & 100 & 100 \\
\hline Hunter Army Airfield & 77 & 100 & 100 & 100 & 100 & 100 & 100 & 100 & 21 \\
\hline Fort Stewart & 2294 & 100 & 97 & 100 & 95 & 100 & 99 & 100 & 14 \\
\hline Arlington National Cemetery & 4 & 100 & 100 & 100 & 100 & 100 & 100 & 100 & 0 \\
\hline Army Reserve Outdoor Training Area & 4 & 100 & 100 & 100 & 100 & 100 & 100 & 100 & 0 \\
\hline Army Training Area & 20 & 100 & 100 & 100 & 100 & 100 & 100 & 100 & 0 \\
\hline Globecom Radio Receiving Station & 15 & 100 & 100 & 100 & 100 & 100 & 100 & 100 & 0 \\
\hline Kearney Rifle Range & 8 & 100 & 100 & 100 & 100 & 100 & 100 & 100 & 0 \\
\hline LaPorte Outdoor Training Facility & 6 & 100 & 100 & 100 & 100 & 100 & 100 & 100 & 0 \\
\hline Malabar Transmitter Annex & 4 & 100 & 100 & 100 & 100 & 100 & 100 & 100 & 0 \\
\hline US Army Reserve Center & 4 & 100 & 100 & 100 & 100 & 100 & 100 & 100 & 0 \\
\hline Florence Military Reservation & 56 & 100 & 100 & 89 & 79 & 89 & 89 & 89 & 63 \\
\hline Camp Grayling Military Reservation & 2451 & 97 & 97 & 97 & 97 & 97 & 94 & 97 & 13 \\
\hline Savanna Army Depot (Scheduled to close) & 228 & 100 & 100 & 100 & 95 & 97 & 95 & 95 & 0 \\
\hline Fort Irwin & 5112 & 91 & 91 & 95 & 88 & 90 & 86 & 92 & 46 \\
\hline Fort Belvoir Military Reservation & 110 & 100 & 100 & 97 & 90 & 90 & 69 & 90 & 29 \\
\hline Camp Roberts Military Reservation & 425 & 95 & 91 & 100 & 97 & 91 & 84 & 89 & 10 \\
\hline
\end{tabular}




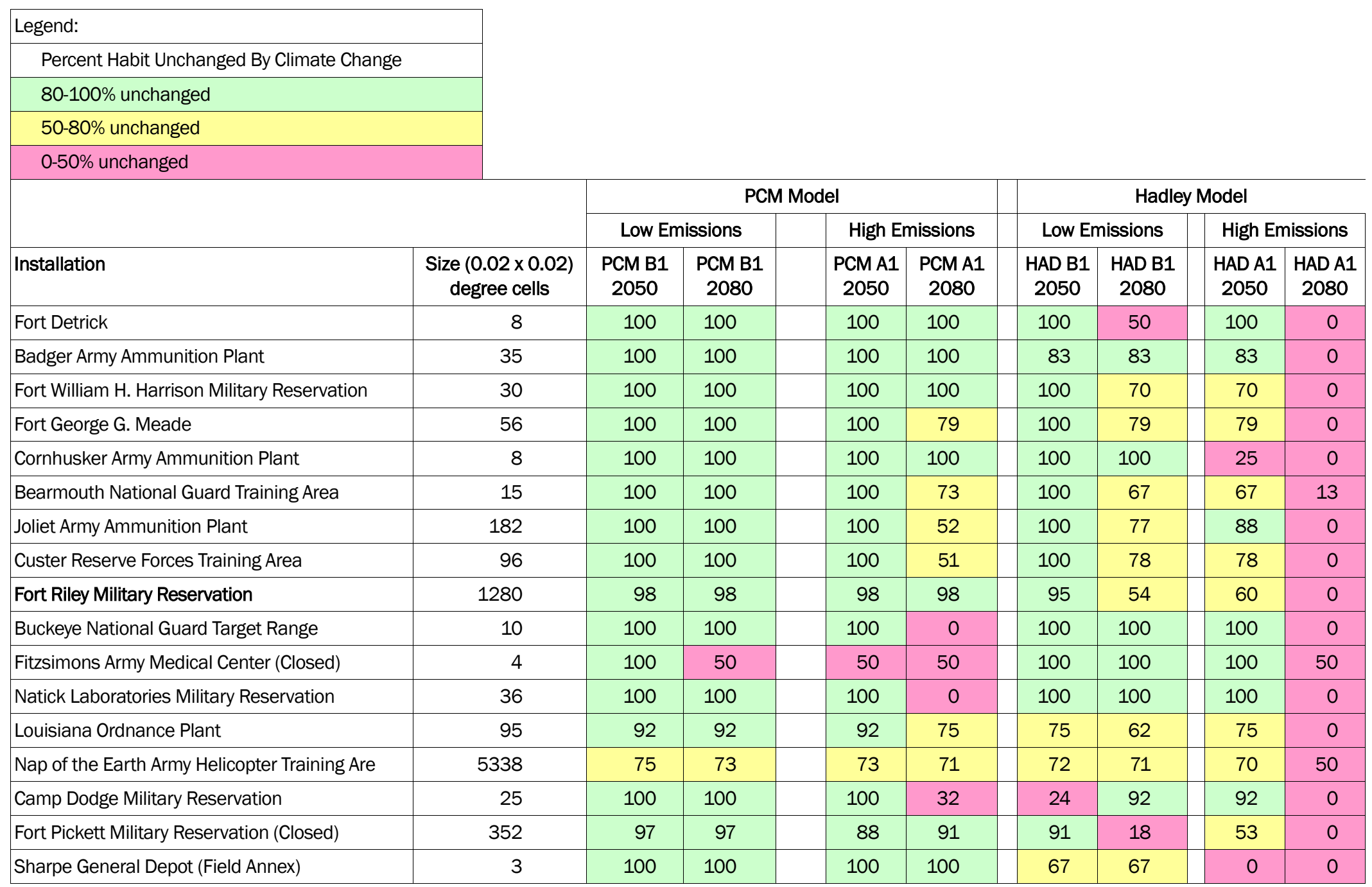




\begin{tabular}{|c|c|c|c|c|c|c|c|c|c|}
\hline \multicolumn{10}{|l|}{ Legend: } \\
\hline \multicolumn{10}{|l|}{ Percent Habit Unchanged By Climate Change } \\
\hline \multicolumn{10}{|l|}{$80-100 \%$ unchanged } \\
\hline \multicolumn{10}{|l|}{$50-80 \%$ unchanged } \\
\hline \multicolumn{10}{|l|}{ 0-50\% unchanged } \\
\hline & & \multicolumn{4}{|c|}{ PCM Model } & \multicolumn{4}{|c|}{ Hadley Model } \\
\hline & & \multicolumn{2}{|c|}{ Low Emissions } & \multicolumn{2}{|c|}{ High Emissions } & \multicolumn{2}{|c|}{ Low Emissions } & \multicolumn{2}{|c|}{ High Emissions } \\
\hline Installation & $\begin{array}{c}\text { Size }(0.02 \times 0.02) \\
\text { degree cells }\end{array}$ & $\begin{array}{l}\text { PCM B1 } \\
2050\end{array}$ & $\begin{array}{l}\text { PCM B1 } \\
2080\end{array}$ & $\begin{array}{c}\text { PCM A1 } \\
2050\end{array}$ & $\begin{array}{l}\text { PCM A1 } \\
2080\end{array}$ & $\begin{array}{c}\text { HAD B1 } \\
2050\end{array}$ & $\begin{array}{l}\text { HAD B1 } \\
2080\end{array}$ & $\begin{array}{l}\text { HAD A1 } \\
2050\end{array}$ & $\begin{array}{l}\text { HAD A1 } \\
2080\end{array}$ \\
\hline Fort McCoy & 713 & 100 & 100 & 100 & 98 & 50 & 47 & 34 & 0 \\
\hline Newport Army Ammunition Plant & 24 & 100 & 100 & 100 & 100 & 75 & 25 & 25 & 0 \\
\hline Dugway Proving Grounds & 3640 & 86 & 78 & 77 & 63 & 71 & 67 & 69 & 8 \\
\hline US Army Aberdeen Proving Ground & 205 & 82 & 77 & 73 & 67 & 62 & 67 & 62 & 27 \\
\hline Aberdeen Proving Ground Military Reservation & 445 & 89 & 78 & 69 & 66 & 57 & 66 & 64 & 22 \\
\hline Camp Bullis & 234 & 100 & 100 & 100 & 48 & 60 & 55 & 48 & 0 \\
\hline Edgewood Arsenal & 40 & 70 & 70 & 70 & 70 & 70 & 70 & 70 & 20 \\
\hline New Cumberland General Depot (US Military R & 130 & 88 & 88 & 78 & 54 & 66 & 54 & 66 & 8 \\
\hline Milan Arsenal And Wildlife Management Area & 234 & 97 & 84 & 84 & 91 & 74 & 12 & 59 & 0 \\
\hline Fort Wolters & 25 & 100 & 100 & 100 & 36 & 52 & 52 & 52 & 0 \\
\hline Fort Lewis Military Reservation & 3089 & 61 & 61 & 64 & 54 & 60 & 56 & 60 & 40 \\
\hline Charles Melvin Price Support Center & 8 & 100 & 100 & 100 & 100 & 25 & 0 & 25 & 0 \\
\hline Fort Devens (Closed) & 140 & 66 & 66 & 66 & 50 & 66 & 66 & 66 & 0 \\
\hline Radford Army Ammunition Plant & 240 & 90 & 87 & 97 & 70 & 27 & 27 & 27 & 19 \\
\hline Camp Swift N. G. Facility & 650 & 100 & 100 & 100 & 37 & 31 & 24 & 29 & 8 \\
\hline Yuma Proving Ground & 6052 & 84 & 74 & 81 & 15 & 73 & 42 & 52 & 1 \\
\hline Fort Rucker Military Reservation & 702 & 74 & 74 & 74 & 74 & 48 & 43 & 28 & 0 \\
\hline
\end{tabular}




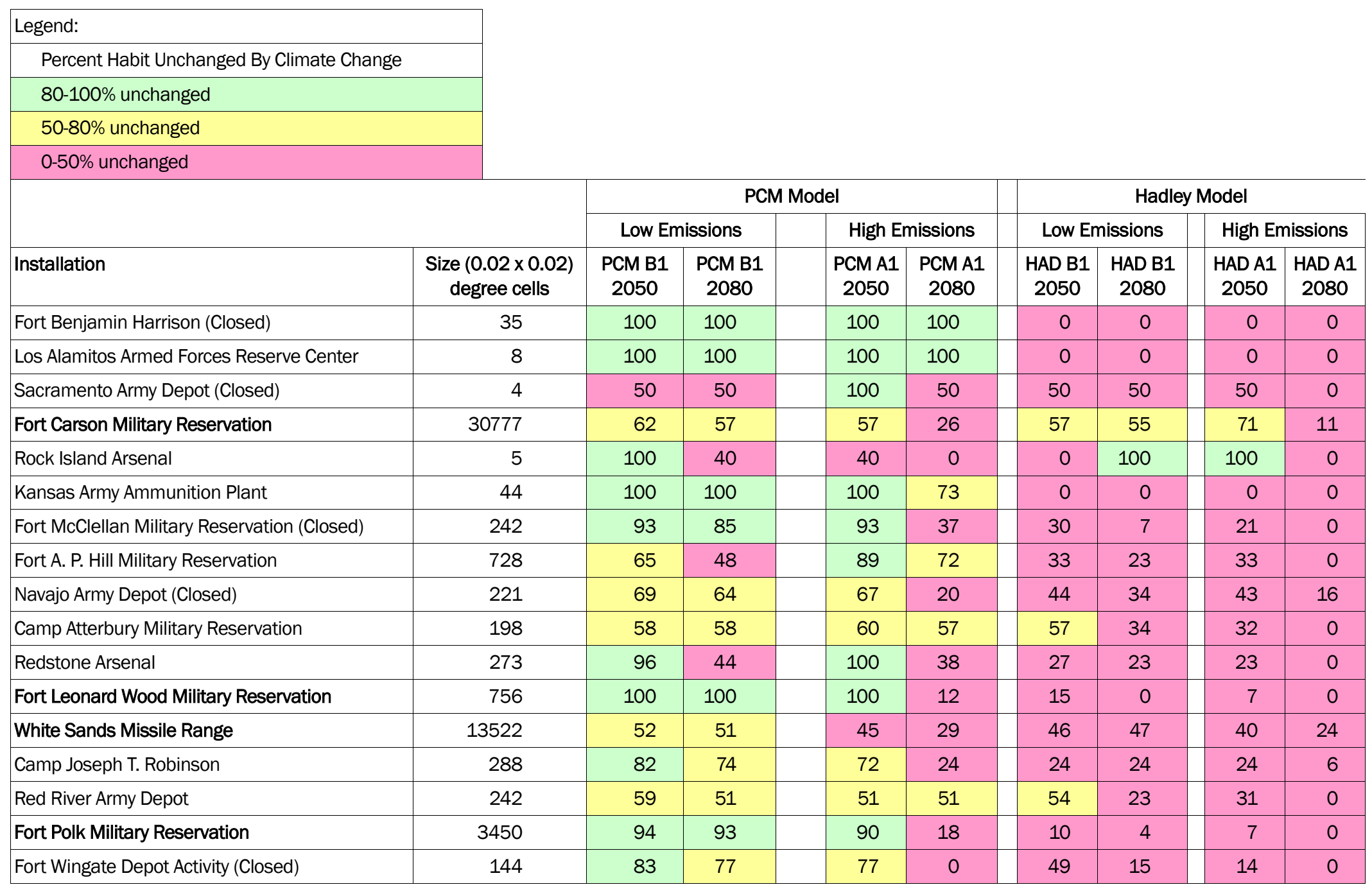




\begin{tabular}{|c|c|c|c|c|c|c|c|c|c|}
\hline \multicolumn{10}{|l|}{ Legend: } \\
\hline \multicolumn{10}{|c|}{ Percent Habit Unchanged By Climate Change } \\
\hline \multicolumn{10}{|l|}{$80-100 \%$ unchanged } \\
\hline \multicolumn{10}{|l|}{$50-80 \%$ unchanged } \\
\hline \multicolumn{10}{|l|}{ 0-50\% unchanged } \\
\hline & & \multicolumn{4}{|c|}{ PCM Model } & \multicolumn{4}{|c|}{ Hadley Model } \\
\hline & & \multicolumn{2}{|c|}{ Low Emissions } & \multicolumn{2}{|c|}{ High Emissions } & \multicolumn{2}{|c|}{ Low Emissions } & \multicolumn{2}{|c|}{ High Emissions } \\
\hline Installation & $\begin{array}{l}\text { Size }(0.02 \times 0.02) \\
\text { degree cells }\end{array}$ & $\begin{array}{l}\text { PCM B1 } \\
2050\end{array}$ & $\begin{array}{l}\text { PCM B1 } \\
2080\end{array}$ & $\begin{array}{c}\text { PCM A1 } \\
2050\end{array}$ & $\begin{array}{l}\text { PCM A1 } \\
2080\end{array}$ & $\begin{array}{c}\text { HAD B1 } \\
2050\end{array}$ & $\begin{array}{l}\text { HAD B1 } \\
2080\end{array}$ & $\begin{array}{l}\text { HAD A1 } \\
2050\end{array}$ & $\begin{array}{l}\text { HAD A1 } \\
2080\end{array}$ \\
\hline Fort Bragg Military Reservation & 1392 & 75 & 52 & 32 & 45 & 31 & 50 & 30 & 1 \\
\hline Lake City Army Ammunition Plant & 18 & 100 & 100 & 100 & 6 & 6 & 0 & 0 & 0 \\
\hline Camp Johnson & 9 & 44 & 44 & 44 & 44 & 44 & 22 & 44 & 22 \\
\hline Fort Leavenworth Military Reservation & 63 & 87 & 100 & 100 & 0 & 16 & 0 & 0 & 0 \\
\hline Fort Hood & 4321 & 72 & 72 & 73 & 22 & 22 & 21 & 21 & 0 \\
\hline Fort Gillem Heliport & 15 & 100 & 100 & 100 & 0 & 0 & 0 & 0 & 0 \\
\hline Fort McPherson & 4 & 100 & 100 & 100 & 0 & 0 & 0 & 0 & 0 \\
\hline Fort Monmouth Military Reservation & 8 & 100 & 100 & 100 & 0 & 0 & 0 & 0 & 0 \\
\hline Longhorn Ordnance Army Ammo Plant & 42 & 100 & 100 & 100 & 0 & 0 & 0 & 0 & 0 \\
\hline Fort Benning Military Reservation & 1599 & 78 & 48 & 81 & 38 & 30 & 11 & 14 & 0 \\
\hline Mount Baker Helicopter Training Area & 8017 & 42 & 42 & 39 & 34 & 40 & 36 & 36 & 25 \\
\hline Buckley Air National Guard AF Base & 30 & 30 & 30 & 30 & 0 & 100 & 50 & 50 & 0 \\
\hline US Army Ammunition Depot & 169 & 98 & 89 & 100 & 2 & 0 & 0 & 0 & 0 \\
\hline Military Ocean Terminal Sunny Point & 150 & 100 & 100 & 80 & 0 & 0 & 0 & 0 & 0 \\
\hline West Point US Military Academy & 121 & 61 & 56 & 68 & 23 & 50 & 10 & 10 & 0 \\
\hline Fort Gordon & 792 & 78 & 64 & 80 & 12 & 19 & 13 & 13 & 0 \\
\hline Fort Campbell & 925 & 96 & 74 & 82 & 4 & 19 & 0 & 1 & 0 \\
\hline
\end{tabular}




\begin{tabular}{|c|c|c|c|c|c|c|c|c|c|}
\hline \multicolumn{10}{|l|}{ Legend: } \\
\hline \multicolumn{10}{|l|}{ Percent Habit Unchanged By Climate Change } \\
\hline \multicolumn{10}{|l|}{$80-100 \%$ unchanged } \\
\hline \multicolumn{10}{|l|}{$50-80 \%$ unchanged } \\
\hline \multicolumn{10}{|l|}{$0-50 \%$ unchanged } \\
\hline & & \multicolumn{4}{|c|}{ PCM Model } & \multicolumn{4}{|c|}{ Hadley Model } \\
\hline & & \multicolumn{2}{|c|}{ Low Emissions } & \multicolumn{2}{|c|}{ High Emissions } & \multicolumn{2}{|c|}{ Low Emissions } & \multicolumn{2}{|c|}{ High Emissions } \\
\hline Installation & $\begin{array}{c}\text { Size }(0.02 \times 0.02) \\
\text { degree cells }\end{array}$ & $\begin{array}{l}\text { PCM B1 } \\
2050\end{array}$ & $\begin{array}{l}\text { PCM B1 } \\
2080\end{array}$ & $\begin{array}{c}\text { PCM A1 } \\
2050\end{array}$ & $\begin{array}{l}\text { PCM A1 } \\
2080\end{array}$ & $\begin{array}{c}\text { HAD B1 } \\
2050\end{array}$ & $\begin{array}{l}\text { HAD B1 } \\
2080\end{array}$ & $\begin{array}{l}\text { HAD A1 } \\
2050\end{array}$ & $\begin{array}{l}\text { HAD A1 } \\
2080\end{array}$ \\
\hline Fort Sill Military Reservation & 900 & 42 & 38 & 38 & 38 & 38 & 38 & 38 & 0 \\
\hline Pine Bluff Arsenal & 288 & 89 & 83 & 87 & 3 & 0 & 0 & 0 & 0 \\
\hline Fort Bliss McGregor Range & 11190 & 35 & 31 & 29 & 35 & 43 & 44 & 23 & 12 \\
\hline Sunflower Army Ammunition Plant & 35 & 83 & 83 & 83 & 0 & 0 & 0 & 0 & 0 \\
\hline Anniston Army Depot & 90 & 70 & 53 & 70 & 20 & 11 & 11 & 11 & 0 \\
\hline Umatilla Chemical Depot (Closed) & 88 & 59 & 55 & 27 & 23 & 24 & 20 & 24 & 0 \\
\hline Warrenton Training Center Military Reservatio & 130 & 47 & 25 & 64 & 18 & 31 & 18 & 22 & 0 \\
\hline Fort Lee Military Reservation & 66 & 36 & 50 & 50 & 27 & 50 & 0 & 0 & 0 \\
\hline Belle Mead General Depot & 8 & 50 & 50 & 50 & 50 & 0 & 0 & 0 & 0 \\
\hline Fort Knox & 2311 & 39 & 39 & 40 & 22 & 25 & 12 & 16 & 0 \\
\hline lowa Army Ammunition Plant & 170 & 72 & 55 & 36 & 7 & 7 & 7 & 7 & 0 \\
\hline Fort Jackson & 527 & 64 & 13 & 13 & 54 & 13 & 13 & 13 & 0 \\
\hline Fort Ritchie Military Reservation (Closed) & 2011 & 27 & 25 & 27 & 19 & 19 & 23 & 22 & 8 \\
\hline Hunter-Liggett Military Reservation & 11581 & 23 & 22 & 23 & 22 & 21 & 19 & 21 & 11 \\
\hline Lexington-Blue Grass Army Depot (Closed) & 1915 & 37 & 36 & 37 & 4 & 4 & 7 & 5 & 0 \\
\hline Fort Dix Military Reservation & 1529 & 20 & 20 & 20 & 14 & 19 & 14 & 13 & 1 \\
\hline Fort Drum & 3877 & 24 & 21 & 24 & 7 & 17 & 10 & 11 & 3 \\
\hline
\end{tabular}




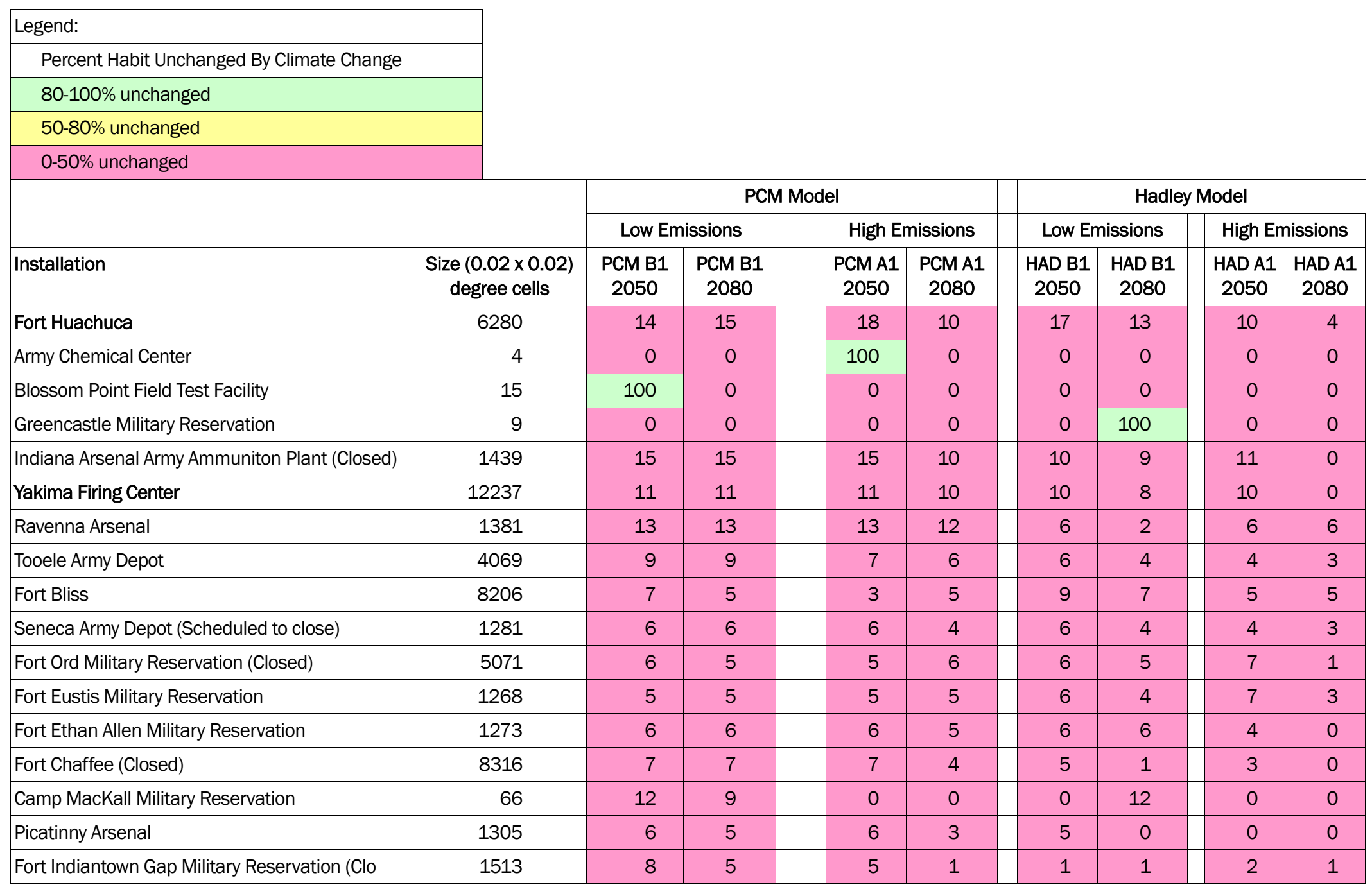




\begin{tabular}{|c|c|c|c|c|c|c|c|c|c|}
\hline \multicolumn{10}{|l|}{ Legend: } \\
\hline \multicolumn{10}{|l|}{ Percent Habit Unchanged By Climate Change } \\
\hline \multicolumn{10}{|l|}{$80-100 \%$ unchanged } \\
\hline \multicolumn{10}{|l|}{$50-80 \%$ unchanged } \\
\hline \multicolumn{10}{|l|}{ 0-50\% unchanged } \\
\hline & & \multicolumn{4}{|c|}{ PCM Model } & \multicolumn{4}{|c|}{ Hadley Model } \\
\hline & & \multicolumn{2}{|c|}{ Low Emissions } & \multicolumn{2}{|c|}{ High Emissions } & \multicolumn{2}{|c|}{ Low Emissions } & \multicolumn{2}{|c|}{ High Emissions } \\
\hline Installation & $\begin{array}{c}\text { Size }(0.02 \times 0.02) \\
\text { degree cells }\end{array}$ & $\begin{array}{l}\text { PCM B1 } \\
2050\end{array}$ & $\begin{array}{l}\text { PCM B1 } \\
2080\end{array}$ & $\begin{array}{c}\text { PCM A1 } \\
2050\end{array}$ & $\begin{array}{l}\text { PCM A1 } \\
2080\end{array}$ & $\begin{array}{c}\text { HAD B1 } \\
2050\end{array}$ & $\begin{array}{l}\text { HAD B1 } \\
2080\end{array}$ & $\begin{array}{l}\text { HAD A1 } \\
2050\end{array}$ & $\begin{array}{l}\text { HAD A1 } \\
2080\end{array}$ \\
\hline Letterkenny Army Depot & 1321 & 5 & 4 & 5 & 2 & 2 & 3 & 2 & 0 \\
\hline Pueblo Chemical Depot (Closed) & 5344 & 2 & 2 & 2 & 2 & 2 & 2 & 3 & 0 \\
\hline Sierra Army Depot & 7107 & 3 & 2 & 3 & 2 & 3 & 2 & 2 & 0 \\
\hline Camp Bonneville Military Reservation (Closed) & 1226 & 2 & 2 & 2 & 2 & 2 & 2 & 3 & 0 \\
\hline Craney Island Disposal Area & 1222 & 2 & 2 & 2 & 2 & 2 & 2 & 2 & 0 \\
\hline Fort Story Military Reservation & 1220 & 1 & 1 & 1 & 1 & 1 & 1 & 1 & 0 \\
\hline Utah Launch Complex White Sands Missle & 5301 & 2 & 1 & 3 & 1 & 1 & 1 & 1 & 0 \\
\hline Camp Parks Military Reservation & 1221 & 2 & 0 & 0 & 0 & 0 & 0 & 0 & 0 \\
\hline Defense Depot Ogden (Closed) & 1208 & 0 & 0 & 0 & 0 & 0 & 0 & 0 & 0 \\
\hline Fort Sheridan (Closed) & 1202 & 0 & 0 & 0 & 1 & 0 & 0 & 0 & 0 \\
\hline Oakland Army Base (Closed) & 3606 & 0 & 0 & 0 & 0 & 0 & 0 & 0 & 0 \\
\hline Presidio of Monterey & 3609 & 0 & 0 & 0 & 0 & 0 & 0 & 0 & 0 \\
\hline Camden Test Annex & 3 & 0 & 0 & 0 & 0 & 0 & 0 & 0 & 0 \\
\hline Fort Ritchie Raven Rock Site & 9 & 0 & 0 & 0 & 0 & 0 & 0 & 0 & 0 \\
\hline Vint Hill Farms Station Military Reservation & 4 & 0 & 0 & 0 & 0 & 0 & 0 & 0 & 0 \\
\hline
\end{tabular}




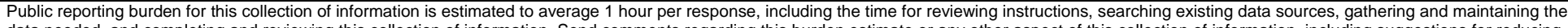

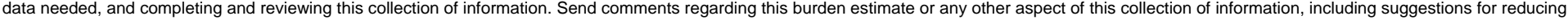

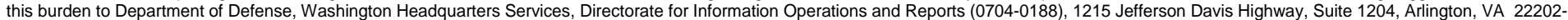

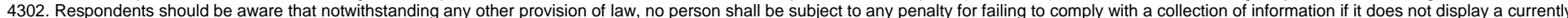
valid OMB control number. PLEASE DO NOT RETURN YOUR FORM TO THE ABOVE ADDRESS.

\begin{tabular}{|l|c|l}
\hline 1. REPORT DATE (DD-MM-YYYY) & 2. REPORT TYPE & 3. DATES COVERED (FrOm - To)
\end{tabular}

\section{TITLE AND SUBTITLE} Final

Forecasting Climate-Induced Ecosystem Changes on Army Installations

5a. CONTRACT NUMBER

5b. GRANT NUMBER

5c. PROGRAM ELEMENT

\section{AUTHOR(S)}

James D. Westervelt and William W. Hargrove

5d. PROJECT NUMBER

5e. TASK NUMBER

5f. WORK UNIT NUMBER

\section{PERFORMING ORGANIZATION NAME(S) AND ADDRESS(ES)}

U.S. Army Engineer Research and Development Center (ERDC)

Construction Engineering Research Laboratory (CERL)

PO Box 9005,

Champaign, IL 61826-9005

8. PERFORMING ORGANIZATION REPORT NUMBER

ERDC/CERL TR-11-36

\section{SPONSORING / MONITORING AGENCY NAME(S) AND ADDRESS(ES)}

U.S. Army Engineer Research and Development Center (ERDC)

Environmental Laboratory (EL)

3909 Halls Ferry Road

Vicksburg, MS 39180-6199

10. SPONSOR/MONITOR'S ACRONYM(S)

CEERD-EM-D

11. SPONSOR/MONITOR'S REPORT NUMBER(S)

\section{DISTRIBUTION I AVAILABILITY STATEMENT}

Approved for public release; distribution is unlimited.

\section{SUPPLEMENTARY NOTES}

\section{ABSTRACT}

Military installation training lands must be managed to support species at risk as well as to be effective training environments for soldiers. Forecasts from various global climate change models suggest that the habitats associated with some military training installations will face pressures that induce biome-shifts, invasive species, loss of habitat, and changes in training opportunities. This study combined worldwide habitat forecast data with a current habitat map to identify major installations that appear to be most and least at-risk for habitat change.

\section{SUBJECT TERMS}

ecosystem management, climate change, habitat, military training, modeling

\begin{tabular}{|l|c|c|}
\hline 16. SECURITY CLASSIFICATION OF: \\
\hline $\begin{array}{c}\text { a. REPORT } \\
\text { Unclassified }\end{array}$ & $\begin{array}{c}\text { b. ABSTRACT } \\
\text { Unclassified }\end{array}$ & $\begin{array}{c}\text { Unclassified } \\
\end{array}$ \\
\hline
\end{tabular}

17. LIMITATION
OF ABSTRACT
SAR

\begin{tabular}{|l|l} 
18. NUMBER & \\
OF PAGES & \\
\cline { 2 - 2 } & \\
&
\end{tabular}

19a. NAME OF RESPONSIBLE PERSON 